UNIVERSIDADE DE SÃO PAULO

FACULDADE DE FILOSOFIA, LETRAS E CIÊNCIAS HUMANAS

DEPARTAMENTO DE CIÊNCIA POLÍTICA

PROGRAMA DE PÓS-GRADUAÇÃO EM CIÊNCIA POLÍTICA

FERNANDA LOPES REGINA

Cooperação Técnica entre Países em Desenvolvimento: 0 Caso do Ministério da Saúde Brasileiro no Haiti

VERSÃO CORRIGIDA

São Paulo

2016 
UNIVERSIDADE DE SÃO PAULO

FACULDADE DE FILOSOFIA, LETRAS E CIÊNCIAS HUMANAS

DEPARTAMENTO DE CIÊNCIA POLÍTICA

PROGRAMA DE PÓS-GRADUAÇÃO EM CIÊNCIA POLÍTICA

\section{Cooperação Técnica entre Países em Desenvolvimento: O Caso do Ministério da Saúde Brasileiro no Haiti}

\section{VERSÃO CORRIGIDA}

De acordo

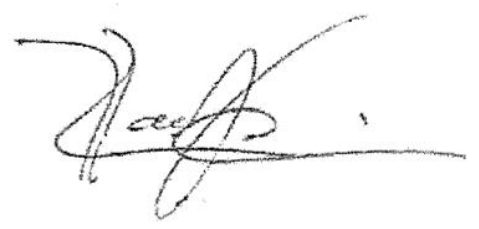

Prof. Dr. João Paulo Cândia Veiga

Fernanda Lopes Regina

Dissertação apresentada ao Programas de Pós-Graduação em Ciência Política, do Departamento de Ciência Política da Faculdade de Filosofia, Letras e Ciências Humanas da Universidade de São Paulo para obtenção do título de Mestre em Ciência Política.

Orientador:

Prof. Dr. João Paulo Cândia Veiga

São Paulo

2016 
Autorizo a reprodução e divulgação total ou parcial deste trabalho, por qualquer meio convencional ou eletrônico, para fins de estudo e pesquisa, desde que citada a fonte.

Catalogação na Publicação

Serviço de Biblioteca e Documentação

Faculdade de Filosofia, Letras e Ciências Humanas da Universidade de São Paulo

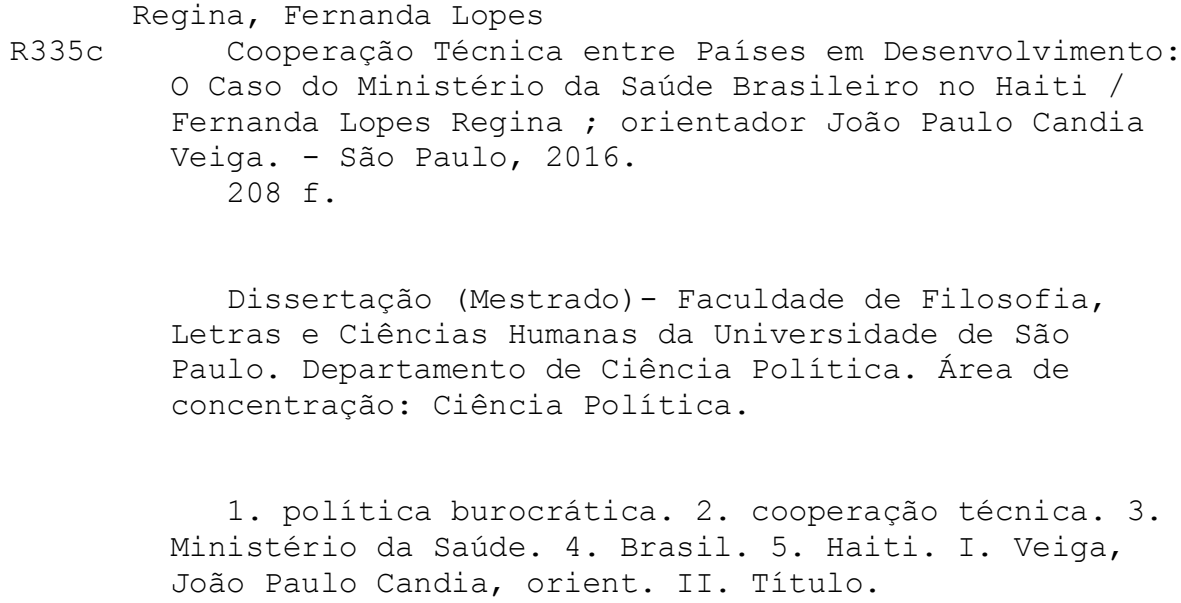


Regina, Fernanda Lopes. Cooperação Técnica entre Países em Desenvolvimento: O Caso do Ministério da Saúde Brasileiro no Haiti. Dissertação apresentada ao Programas de Pós-Graduação em Ciência Política, do Departamento de Ciência Política da Faculdade de Filosofia, Letras e Ciências Humanas da Universidade de São Paulo para obtenção do título de Mestre em Ciência Política.

Aprovado em:

\section{BANCA EXAMINADORA}

Prof. Dr. Instituição:

Julgamento: Assinatura:

Prof. Dr. Instituição:

Julgamento: Assinatura:

Prof. Dr. Instituição:

Julgamento: Assinatura: 
Em memória do meu pai. 


\section{Agradecimentos}

Esta dissertação é resultado de uma aproximação com a questão haitiana ocorrida ainda em 2011, em razão de interesses pessoais decorrentes do terremoto de 12 de janeiro de 2010. Desde então, diferentes pessoas estiveram presentes no processo de desenvolvimento do tema, de modo que eu não conseguiria agradecer ao incentivo de todas elas, mas destaco em primeiro lugar a Capes, responsável pelo financiamento deste projeto.

Agradeço ao Marcelo Haydu, diretor executivo da Adus | Instituto de Reintegração do Refugiado - Brasil, que a partir do trabalho desempenhado com refugiados (também haitianos) que se encontram em São Paulo, contribuiu por reforçar o meu comprometimento com uma causa tão sensível e desafiadora.

Ao Núcleo de Estudos da Violência da USP (NEV-USP), por possibilitar minha aproximação com o tema dos direitos humanos, que me sensibilizou profundamente e abriu portas, ainda que indiretamente, para o meu posterior contato com a questão haitiana. Reforço o agradecimento ao professor Sérgio Adorno, com quem aprendi durante minha passagem pelo NEV a desenvolver posicionamentos críticos e o rigor metodológico, fundamentais no exercício da pesquisa acadêmica. E ainda à minha antiga (mas sempre atual) coordenadora, Maria Fernanda Peres, não apenas pela oportunidade de integrar sua equipe de pesquisa, mas pela confiança desde sempre depositada em meu trabalho. Ao Departamento de Ciência Política da USP, por proporcionar uma rica experiência acadêmica, a partir da qual pude conhecer pessoas muito especiais, e professores, pelos quais tenho profunda admiração. Ao professor João Paulo Veiga (Joca), pela orientação, discussões, paciência e compreensão durante todo o processo de desenvolvimento da dissertação; à professora Janina Onuki pelo incentivo e credibilidade depositados na pesquisa ainda em fase inicial no ano de 2014, quando cursava sua disciplina de Política Externa Brasileira; ao professor Rafael Villa, que primeiro me incentivou à buscar no processo decisório da política de cooperação com o Haiti o elemento empírico para a consecução do trabalho e ao professor Feliciano de Sá (IRIUSP), por todas as críticas e sugestões apresentadas no exame de qualificação.

Agradeço ainda aos representantes do Ministério das Relações Exteriores e do Ministério da Saúde, pela disponibilidade e colaboração em aceitarem participar das entrevistas que 
foram indispensáveis para elucidar os principais problemas iniciais de pesquisa, em especial ao último, por todo o apoio fornecido em momentos precedentes e posteriores à minha ida à Brasília.

E nada mais justo agradecer à todas as pessoas importantes na minha vida e que participaram deste processo. Em primeiro lugar à minha mãe Ana, por apoiar todas as minhas decisões, fornecendo o amparo emocional sem o qual eu seria incapaz de ter chegado até aqui. Às minhas irmãs Patrícia e Priscila, por sempre acreditarem em minha capacidade profissional e de renovação pessoal. À minha sobrinha e afilhada Ana Clara, que mesmo ainda sem saber, tornou-se a principal razão da minha caminhada.

Às minhas amigas: Alexsandra Laska, pelos anos de amor incondicional, apoio e amizade, que mesmo de longe continuam a ser imprescindíveis pra mim; Érika Kitahara, pela cumplicidade de anos, em uma relação de muito amor que não se esgota jamais; Caren Ruotti, pela parceria ímpar, com quem aprendi e cresci muito profissionalmente, e que se tornou uma grande amiga com quem divido todos os meus momentos; Viviane Massa, pela cumplicidade de todos estes anos, com quem aprendi a valorizar um grande amigo em sua essência e a estabelecer laços emocionais que não se rompem; Maria Clara Oliveira, o melhor presente que ganhei em minha passagem pelo DCP, e que se tornou ao longo do tempo uma grande amiga pela qual tenho muito amor e gratidão; Letícia Lago, uma grande amiga de infância com a qual tenho o privilégio de dividir depois de quase 20 anos, muito companheirismo e as diferentes passagens da minha vida. E em especial, agradeço à Kássia Vitorazzo, amiga da qual guardarei por toda a minha vida as minhas melhores lembranças dos quase onze anos de amizade, e a quem dedico também este trabalho. 


\section{RESUMO}

O objetivo desta dissertação é analisar a função política exercida pelo Ministério da Saúde (MS) na política de Cooperação Técnica entre Países em Desenvolvimento (CTPD), empreendida com o Haiti durante o governo do ex-presidente Luiz Inácio Lula da Silva (2003-2010). Para isso, propõe a construção de uma análise transversal que engloba os estudos sobre as burocracias, oriundos da Ciência Política, e as recentes pesquisas sobre o crescente engajamento dos ministérios para a consecução da agenda política de Cooperação Sul-Sul (CSS), pertencentes à Análise de Política Externa (APE), do campo das Relações Internacionais. Neste sentido, a pesquisa lança mão do estudo de caso do Projeto Sul-Sul de Fortalecimento da Autoridade Sanitária do Haiti - PRODOC$B R A / 10 / 2005$, assinado em 29 de novembro de 2010, a fim de verificar a maneira pela qual, a estrutura institucional do MS desempenhou simultaneamente as funções de formulação e implementação da referida política.

PALAVRAS-CHAVE: política burocrática, cooperação técnica, Ministério da Saúde, Brasil, Haiti. 


\begin{abstract}
The aim of this dissertation is to analyze the political function exercised by the Ministry of Health on the Technical Cooperation policy between Developing Countries undertaken with Haiti during the government of former President Luiz Inácio Lula da Silva (20032010). For such purpose, it is proposed to build a cross-sectional analysis that includes studies of bureaucracies arising from Political Science and recent researches on the increasing engagement of the ministries to achieve South-South Cooperation political agenda belonging pertaining to the Foreign Policy Analysis of the International Relations field. In this regard, the research makes use of the case study of South-South Project of Haiti Sanitary Authority Strengthening - PRODOC-BRA / 10/2005, signed on November 29,2010 , in order to verify the way in which the Ministry of Health institutional structure simultaneously played both formulation and implementation functions of said policy.
\end{abstract}

KEYWORDS: bureaucratic policy, technical cooperation, Ministry of Health, Brazil, Haiti. 


\section{FIGURAS}

Figura 1. Ciclo da Política Pública

Figura 2. Competência dos atores de acordo com Kingdon

Figura 3. Natureza do Domínio de acordo com Rosati

Figura 4. Ciclo de solicitação de uma iniciativa de CTPD ao governo brasileiro pelo Haiti Figura 5. Etapas para a elaboração do projeto Construção de Cisternas Captação e Armazenamento de Água da Chuva e de Promoção de Ações de Fortalecimento da Agricultura Familiar e da Segurança Alimentar

Figura 6. Ciclo dos projetos de CTPD

Figura 7. Unidades do Ministério da Saúde que possuíam competência em política externa em 2010 organizados por Secretarias

Figura 8. Listagem dos projetos de CTPD desenvolvidos pelo Ministério da Saúde entre Brasil e Haiti (2006-2009)

Figura 9. Listagem dos projetos de CTPD desenvolvidos pelo Ministério da Saúde entre Brasil e Haiti (2010)

Figura 10. Natureza dos Domínios do presidente e do Ministério da Saúde para o PRODOC- BRA/10/2005 de acordo com Rosati

Figura 11. Processo para o estabelecimento do Memorando de Entendimento para o Fortalecimento do Sistema e dos Serviços Públicos de Saúde e de Vigilância Epidemiológica no Haiti entre Brasil e Haiti

Figura 12. Processo para o estabelecimento do projeto BRA/10/005 entre Brasil e Haiti a partir do reconhecimento da presença dos atores em cada etapa

Figura 13. Representação gráfica dos grupos das unidades do Ministério da Saúde segundo suas competências em 2010

Figura 14. Atores Presentes nos Níveis Decisórios do Projeto Haiti

Figura 15. Fases do Ciclo de Projetos de CTPD

Figura 16. Fases do Ciclo do Projeto Instituto Haiti-Brasil de Reabilitação de Pessoas com Deficiência na Secretária de Atenção à Saúde (SAS)

Figura 17. Fases do Ciclo do Projeto para a internacionalização de Políticas de Medicamentos Brasileira pela Secretaria de Ciência, Tecnologia e Insumos Estratégicos (SCTIE) 


\section{GRÁFICOS}

Gráfico 1. Número de Proposições de Acordos de CTPD por Mandato (1970 - 2010)

Gráfico 2. Proposições de Acordo de CTPD (1995-2010)

Gráfico 3. Número de projetos de CTPD entre Brasil e Haiti (2005 - 2010)

Gráfico 4. Projetos de CTPD entre Brasil e Haiti por Área (2005-2010)

Gráfico 5. Principais Projetos de Cooperação Sul-Sul em Saúde por Área (2009)

\section{TABELAS}

Tabela 1. Distinção das Funções do Poder Executivo

Tabela 2. Síntese da Aplicação do Modelo do Ponctuated Equilibrium à Política de CTPD $(1970-2010)$

Tabela 3. Acordos e Ajustes Complementares de Cooperação Técnica entre Brasil Haiti (2004-2010)

Tabela 4. Memorandos de Entendimento e Declarações Conjuntas entre Brasil e Haiti (2004-2010)

Tabela 5. Protocolos de Intenções entre Brasil e Haiti (2004-2010)

Tabela 6. Fases de elaboração dos projetos de cooperação normatizadas pela ABC

Tabela 7. Fases de gestão dos projetos de cooperação normatizadas pela ABC

Tabela 8. Principais Políticas desenvolvidas pelo Ministério da Saúde (década de 1970 a 1990)

Tabela 9. Decretos presidenciais que autorizam a Estrutura Regimental e Quadro Demonstrativo dos Cargos do Ministério da Saúde (2003-2010)

Tabela 10. Competências em Política Externa dos Decretos presidenciais que autorizam a Estrutura Regimental e Quadro Demonstrativo dos Cargos do Ministério da Saúde (2003 e 2010)

Tabela 11. Comparação entre os órgãos que possuem competência em política externa entre os Organogramas Internos do Ministério da Saúde (2003 e 2010)

Tabela 12. Atos Internacionais para o desenvolvimento de cooperação técnica pelo Ministério da Saúde entre Brasil e Haiti (2006-2009)

Tabela 13. Atos Internacionais para o desenvolvimento de cooperação técnica pelo Ministério da Saúde entre Brasil e Haiti (2010) 
Tabela 14. Competências das Secretarias e suas Unidades Integrantes do Projeto Haiti de acordo com Regimento Interno (2010)

Tabela 15. Funções Exercidas pelas Secretarias e suas Unidades no Projeto Haiti 


\section{ANEXOS}

ANEXO 1. Atos Internacionais Celebrados para Implementação de Cooperação Técnica em prol do Haiti (2004 -2010).

ANEXO 2. Projetos de Cooperação Técnica com o Haiti (2005 - 2010).

ANEXO 3. Missões de Avaliação e Prospecção Realizadas no Haiti (2004 - 2010).

ANEXO 4. Competência dos órgãos do Ministério da Saúde para a formulação de iniciativas de política externa em 2010.

ANEXO 5. Competência dos órgãos do Ministério da Saúde para a implementação de iniciativas de política externa em 2010.

ANEXO 6. Competência dos órgãos do Ministério da Saúde para a formulação e implementação de iniciativas de política externa em 2010, 


\section{LISTA DE SIGLAS}

ABC - Agência Brasileira de Cooperação

AISA - Assessoria de Assuntos Internacionais

ANS - Agência Nacional de Saúde Suplementar

ANVISA - Agência Nacional de Vigilância Sanitária

APE - Análise de Política Externa

ASA - Semiárido Brasileiro

ASCOM - Assessoria de Comunicação Social do Ministério da Saúde

BID - Banco Interamericano de Desenvolvimento

BIRD - Banco Internacional para Reconstrução e Desenvolvimento

CALC - I Cúpula da América Latina e do Caribe sobre Integração e Desenvolvimento

CARICOM - Comunidade do Caribe

CDH - Comissão de Direitos Humanos

CELAC - Comunidade dos Estados Latino-Americanos e Caribenhos

CGFome - Coordenação Geral de Combate à Fome do Itamaraty

CGT - Comitê Gestor Tripartite

CGVAM - Coordenação-Geral de Vigilância em Saúde Ambiental do Ministério da

Saúde

CID - Cooperação Internacional para o Desenvolvimento

CIEVS - Centro de Informações Estratégicas e Resposta em Vigilância em Saúde do Ministério da Saúde

CLP - Comunidade dos Países de Língua Portuguesa

CNJ - Conselho Nacional de Justiça

COBRADI - Cooperação Brasileira para o Desenvolvimento Internacional

CODEVASF - Companhia de Desenvolvimento do Vales do São Francisco e do Parnaíba

CONAB - Companhia Nacional de Abastecimento

CQCT - Grupo de Trabalho Intergovernamental de Composição Aberta da Convenção

Quadro para o Controle do Tabaco

CSNU - Conselho de Segurança das Nações Unidas

CSS - Cooperação Sul-Sul

CT - Cooperação Técnica

CTI - Cooperação Técnica Internacional

CTPD - Cooperação Técnica entre Países em Desenvolvimento

DAE - Departamento de Atenção Especializada do Ministério da Saúde

DAF - Departamento de Assistência Farmacêutica e Insumos Estratégicos do Ministério da Saúde

DAS - Cargos de Direção e Assessoramento

DESID - Departamento de Economia da Saúde, Investimentos e Desenvolvimento

DEVEP - Departamento de Vigilância Epidemiológica do Ministério da Saúde

DLOG - Departamento de Logística do Ministério da Saúde

DPF - Departamento da Polícia Federal 
DVSAST - Departamento de Vigilância em Saúde Ambiental e Saúde do Trabalhador do Ministério da Saúde

EMATER/DF - Empresa de Assistência Técnica e Extensão Rural do Distrito Federal

EMBRAPA - Empresa Brasileira de Pesquisa Agropecuária

EOP - Executive Office of the President

FAO - Organização das Nações Unidas para a Agricultura e Alimentação

FIOCRUZ - Fundação Oswaldo Cruz

FMI - Fundo Monetário Internacional

FUNASA - Fundação Nacional de Saúde

G77 - Grupo dos 77

GM - Gabinete do Ministro do Ministério da Saúde

Grupo do Rio - Mecanismo Permanente de Consulta e Concertação Política

HSL - Hospital Sírio Libanês - Instituto de Ensino e Pesquisa

IBGE - Instituto Brasileiro de Geografia e Estatística

INCA - Instituto Nacional do Câncer

INFRAERO - Empresa Brasileira de Infraestrutura Aeroportuária

IPEA - Instituto de Pesquisa Econômica Aplicada

MAPA - Ministério da Agricultura, Pesca e Abastecimento

MCT - Ministério da Ciência e MDIC - Ministério do Desenvolvimento, Indústria e

Comércio Exterior

MDA - Ministério do Desenvolvimento Agrário

MdE - Memorandos de Entendimento

MDS - Ministério do Desenvolvimento Social e Combate à Fome

MEC - Ministério da Educação

MI - Ministério da Integração

MINUSTAH - Missão das Nações Unidas para Estabilização do Haiti (),

MMA - Ministério do Meio Ambiente

MME - Minas e Energia

MP - Medidas Provisórias

MPS - Previdência Social

MRE - Ministério das Relações Exteriores

MS - Ministério da Saúde

MT - Ministério do Turismo

MTE - Ministério do Trabalho e Emprego

NES - Cargos de Natureza Especial

OADI - Órgãos de Assistência Direta e Imediata

ODM - Objetivos de Desenvolvimento do Milênio

OEA - Organização dos Estados Americanos

OES - Órgãos Específicos Singulares

OI - Organização Internacional

OIT - Organização Internacional do Trabalho

OMS - Organização Mundial da Saúde ().

ONU - Organização das Nações Unidas

ONUDI - Organização das Nações Unidas para o Desenvolvimento Industrial 
OPAS - Organização Pan-Americana da Saúde

OTAN - Organização do Tratado do Atlântico Norte

PA - Teoria Principal-Agente

PAA - Programas de Aquisição de Alimentos

PABA - Plano de Ação de Buenos Aires

PCB - Partido Comunista

PDT - Partido Democrático Trabalhista

PEB - Política Externa Brasileira

PEC - Projetos de Emenda Constitucional

PL - Projetos de Lei

PLP - Projetos de Lei de Conversão

PMA - Programa Mundial de Alimentação

PMDB - Partido do Movimento Democrático Brasileiro

PNI - Programa Nacional de Imunizações

PNUD - Programa das Nações Unidas para o Desenvolvimento

PPREPS - Programa de Preparação Estratégica de Pessoal em Saúde, o,

PPS - Partido Popular Socialista

PRODIRS - Programa de Difusão e Intercâmbio sobre Reforma Sanitária

PSDB - Partido da Social Democracia Brasileira

PT - Partido dos Trabalhadores

SAS- Secretaria de Atenção à Saúde do Ministério da Saúde

SBIBHAE - Sociedade Beneficente Israelita Brasileira Hospital Albert Einstein

SCI - Sistema de Atos Internacionais

SCTIE - Secretaria de Ciência, Tecnologia e Insumos Estratégicos do Ministério da Saúde

SDH/PR - Secretaria de Direitos Humanos da Presidência da República

SE/MS - Secretaria-Executiva do Ministério da Saúde

SENAC - Serviço Nacional de Aprendizagem Comercial

SEPM/PR - Secretaria Especial de Políticas para as Mulheres

SERPRO - Serviço Federal de Processamento de Dados

SGEP - Secretaria de Gestão Estratégica e Participativa do Ministério da Saúde

SGTES - Secretaria de Gestão do Trabalho e da Educação na Saúde do Ministério da

Saúde

SISCOOP - Sistema de Acompanhamento de Projetos e Atividades de Cooperação

SUS - Sistema Único de Saúde

SVS - Secretaria de Vigilância em Saúde do Ministério da Saúde

UE - União Europeia

UFRGS - Universidade Federal do Rio Grande do Sul

UFRRJ - Universidade Federal Rural do Rio de Janeiro

UFSC - Universidade Federal de Santa Catarina

UFSM - Universidade Federal de Santa Maria

UNCTAD - Conferência das Nações Unidas sobre Comércio e Desenvolvimento

UNICEF - Fundo das Nações Unidas para a Infância

UNOPS - Escritório das Nações Unidas para Serviços de Projetos

USP - Universidade do Estado de São Paulo 


\section{SUMÁRIO}

INTRODUÇÃO

CAPÍTULO 1. ABORDAGENS TEÓRICAS PARA O ESTUDO DAS BUROCRACIAS ESTATAIS E SUA ATUAÇÃO EM POLÍTICA EXTERNA …................................ 31

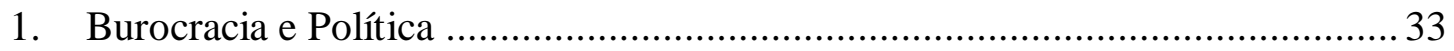

1.1. O Estabelecimento do Agenda-Setting .................................................. 38

1.2. Teoria Principal-Agente (PA): Princípios da Discricionariedade

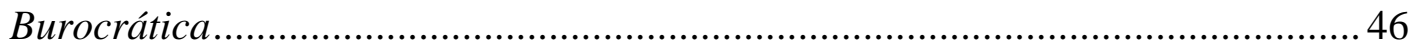

2. A Análise de Política Externa: A Presença de Diferentes Atores........................52

2.1. Burocracia e Política Externa ...................................................................5 57

2.2. Agenda-Setting em Política Externa .........................................................5 59

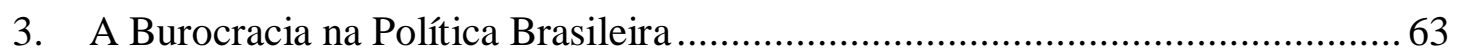

4. Burocracia Brasileira e Política Externa.............................................................6 69

4.1. O insulamento burocrático do Itamaraty ..................................................69

4.2. Política Externa como Política Pública ..................................................... 72

4.3. A Horizontalização das Competências no contexto da Cooperação Sul-Sul73

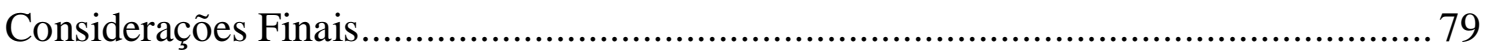

CAPÍTULO 2. COOPERAÇÃO ENTRE PAÍSES EM DESENVOLVIMENTO: A

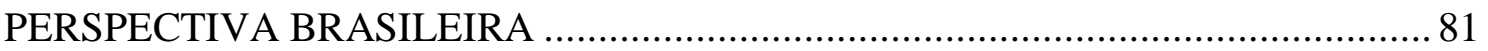

1. Breve Histórico Internacional da CSS e da CTPD.............................................. 82

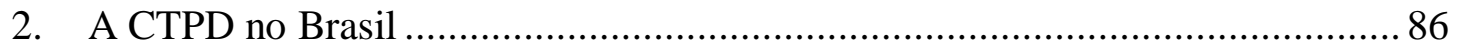

3. A CTPD Brasileira no Haiti........................................................................... 98

3.1. Brasil no Haiti: Uma análise quantitativa e qualitativa ......................... 103

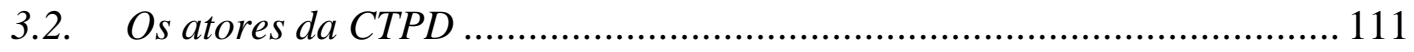

3.3. Ciclo de Gestão das Iniciativas de CTPD ............................................. 115

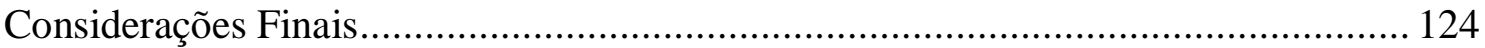

CAPÍTULO 3. A COOPERAÇÃO TÉCNICA ENTRE PAÍSES EM DESENVOLVIMENTO: O CASO DO MINISTÉRIO DA SAÚDE ......................... 126

1. A Cooperação Internacional em Saúde no Brasil ........................................... 127

2. A Delegação Política do ex-Presidente Lula ao Ministério da Saúde em Política

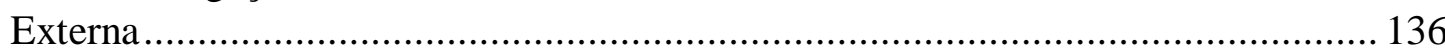

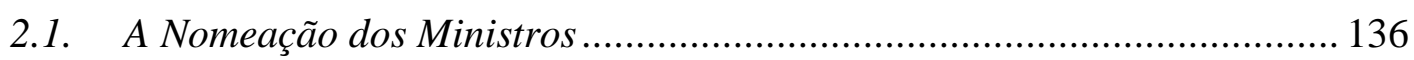

2.2. Os Decretos Presidenciais e os Regimentos Internos do MS ................... 144 
4. A Cooperação Técnica do Ministério da Saúde no Haiti: Um Estudo de Caso do Projeto Sul-Sul de Fortalecimento da Autoridade Sanitária do Haiti-PRODOCBRA/10/2005

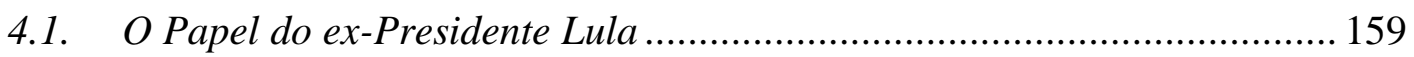

4.2. $\quad$ O Gabinete de Gerenciamento de Crise ................................................... 161

4.3. As Competências das Secretarias e Órgãos do MS no âmbito do Grupo de Trabalho Projeto Haiti................................................................................... 165

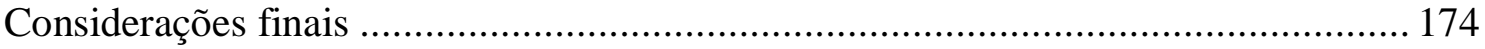

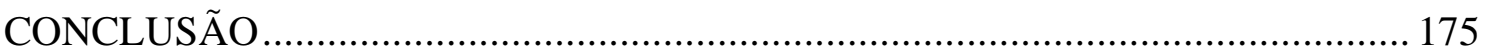

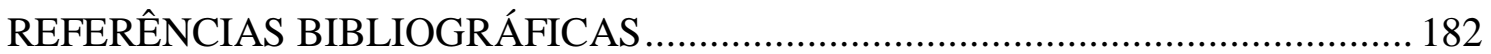




\section{INTRODUÇÃO}

A importância atribuída ao papel exercido por elementos internos aos Estados, tais como suas políticas públicas, burocracias, atores, agendas e grupos, tomou forma nos debates sobre a política internacional a partir da Análise de Política Externa (APE), que mais profundamente relacionou os campos de pesquisa das Relações Internacionais e da Ciência Política. Três diferentes abordagens da APE inauguraram e continuam a influenciar os estudos sobre esta questão: i) Comparative Foreign Policy, de James N. Rosenau em 1966; ii) Foreign Policy Decision Making, de Richard C. Synder, H.W. Bruck e Burton Sapin, em 1963 e iii) Foreign Policy Context, de Harold e Margaret Sprout, de 1956 (Hudson and Vore, 1995).

Destas discussões iniciais, três conjuntos de temas assumiram lugar nos subsequentes trabalhos provenientes deste campo. Por um lado, tem-se a opinião pública (Page and Shapiro, 1992; Holsti, 2002) e os grupos de interesse (Risse-Kapen, 1991, 1995; Milner, 1995), que abordam a presença de atores não estatais nos assuntos inerentes à política externa; e por outro, o presidente e as burocracias (Huntington, 1961; Schilling, Hammon, and Snyder, 1962; Neustadt, 1970; Allison, 1971; Allison and Halperin, 1972), que entendem que as decisões do Estado relacionam-se à processos que ocorrem principalmente no interior do Poder Executivo (Kaarbo et al., 2001).

Não é o objetivo do trabalho revisitar todas as abordagens e seus desdobramentos, embora seja reconhecida a contribuição de cada uma delas ao campo. Entretanto, interessa de forma particular os mecanismos decisórios que tomam lugar no Executivo, partindo do pressuposto de que são os integrantes do governo, mediante o poder atribuído por seus cargos, que tomam a decisão em nome do Estado (Risse-Kapen, 1995). Assume-se que a relação que se estabelece entre presidente e burocracias possibilita o entendimento da maneira pela qual os últimos exercem também um impacto substancial na formalização das escolhas.

Allison (1971) buscou justamente compreender essa imbricada rede na política externa norte-americana, através da análise da crise dos mísseis cubana que ocorreu em 1962. Para isto, ele propôs - além de outros dois - o Modelo de Política Burocrática, no qual a política externa foi apresentada como um processo que envolve a dinâmica entre partes 
da burocracia estatal, operada por meio de barganhas e alianças das quais ela utiliza-se para atingir seus objetivos. Para ele, estes diferentes atores compartilham o poder na tomada de decisões, dada a dificuldade que os líderes políticos possuem em controlar individualmente as incontáveis redes organizacionais que os cercam. Para entender, então, porque determinada decisão governamental foi tomada, é necessário antes identificar tanto o "jogo" como os "jogadores", revelando suas coalizões, barganhas e compromissos.

O modelo, entretanto, recebeu algumas críticas que, em grande medida apontaram para o fato de que Allison diminuiu o poder exercido pelo presidente igualando-o aos demais “jogadores”. Para estes autores, ainda que a presença dos quadros burocráticos possa não ser muito clara, estes grupos são compostos por indivíduos frequentemente indicados pelo próprio presidente a partir de cálculos estratégicos, a fim de garantir que as decisões tomadas em seu nome, estejam em sincronia com suas preferências. Assim, o que garante o funcionamento mais ou menos autônomo de determinada burocracia vai depender do tipo de política em quadro, bem como da personalidade do presidente, podendo este envolver-se diretamente ou não nas decisões a serem tomadas (Krasner, 1972; Rosati, 1981).

A dissertação toma essas críticas como o elemento basilar de toda a discussão que será desenvolvida a fim de desobscurecer os mecanismos políticos que geriram a Cooperação Sul-Sul (CSS) brasileira entre 2003 e 2010 - período do governo de Luiz Inácio Lula da Silva - utilizando como estudo de caso a Cooperação Técnica entre Países em Desenvolvimento (CTPD) empreendida pelo Ministério da Saúde (MS) no Haiti. A argumentação centra-se no valor explicativo que a mudança institucional, resultante da posse de Lula, teve para que a corrente de pensamento até então vigente entre os quadros do Ministério das Relações Exteriores (MRE), sofresse alterações no que diz respeito à leitura feita pelo governo do sistema internacional, bem como do papel que deveria ser exercido pelo Brasil nesse novo cenário.

Conforme ficará demonstrado, o MS acompanhou essas mudanças a começar por alterações no quadro de comando da pasta, em que nomeações políticas e técnicas, constituíram-se enquanto o mais importante mecanismo de controle ex ante empregado 
pelo presidente Lula, à luz do que é preconizado pela Teoria do Principal-Agente (PA), integrante do rol de estudos sobre a delegação política.

É importante ressaltar, entretanto, que esse fato não significa que tenha havido obrigatoriamente um alinhamento automático do presidente com pelo menos os três últimos representantes do ministério durante o período que compreendeu os dois mandatos de Lula, uma vez que a própria natureza do regime presidencialista de coalização vigente no Brasil, exigiu do chefe do Executivo grande esforço estratégico capaz de conciliar interesses distintos para assegurar as mínimas condições necessárias para a implementação de seu projeto de governo na área da saúde. A esse respeito, por hora importa dizer que, não obstante o cenário de incertezas e disputas político-partidárias que marcaram os períodos de transição ministerial, os quatro ministros da pasta estabeleceram compromissos com o presidente tanto para colaborar na manutenção de um ambiente propício para a governabilidade do país quanto para tentar alinhar - o quanto mais fosse possível - as demandas de seus partidos e as do próprio presidente.

Posto isso, no que diz respeito aos estudos sobre a política externa brasileira (PEB) realizados nos últimos anos, muitos autores apontam para o rompimento do caráter insular do Itamaraty no tocante à decisão e implementação de políticas (Cason e Power, 2009; Lopes, 2011; Pimenta de Faria, 2012a; Milani, 2014). Em consonância com o postulado mais geral da APE, estas pesquisas indicam a atuação de uma pluralidade de atores e agendas, incluindo os não-governamentais (ONGs e empresas privadas) - os quais, reitera-se, não serão tratados neste trabalho - e os estatais, como Ministérios, Agências Federais e Entidades Subnacionais. No que tange ao escopo da dissertação, estes autores têm trazido para a discussão a importância dos Ministérios diante desta nova configuração política, levantando questionamentos acerca do papel desempenhado pelo MRE e pelo presidente neste processo.

Quanto ao MRE, o que foi possível depreender da pesquisa empírica realizada junto à Agência Brasileira de Cooperação (ABC) - órgão vinculado ao Itamaraty e que responde pela coordenação dos projetos de cooperação recebida e empreendida pelo país - é que as respostas aos questionamentos iniciais do trabalho seriam com maior êxito obtidas através dos próprios Ministérios envolvidos com a CTPD no Haiti. Esta constatação, entretanto, não só deve, como será tratada com muita cautela ao longo do trabalho, visto que ela pode 
facilmente induzir ao erro de marginalizar a importância do MRE neste tipo específico de política, o que não é verdade, uma vez que ele participa durante todo o processo de discussão e negociação com os países com o qual o Brasil coopera, sendo inclusive o ministro das Relações Exteriores, o principal ator no momento da assinatura dos atos internacionais para a Cooperação Técnica (CT) celebrados pelo governo brasileiro. Mas, uma vez que este tipo de política tem como elemento principal o conhecimento técnico, é evidente que sua consecução depende obrigatoriamente dos Ministérios, os únicos neste caso, a possuir informações detalhadas que são imprescindíveis para a realização de pesquisas como a que será aqui desenvolvida.

Ainda que esta explicação seja necessária, possui pouca importância analítica ao trabalho como um todo, uma vez que este toma como foco os papéis desempenhados pelo MS e o Presidente da República, utilizando como argumento a definição de Souza (2006a) para quem os dois ministérios estabelecem entre si, uma relação cooperativa, já que ambos estão submetidos à autoridade presidencial, única responsável de fato, por coordenar o conjunto das instituições políticas nas quais as decisões são tomadas. Deste modo, partese do pressuposto que a autoridade exercida pelo presidente Lula - embora não deva ser considerada a única razão ${ }^{1}$ - pode, em grande medida, explicar não somente as dimensões tomadas pela CTPD, mas também o elevado grau de atenção que se conferiu ao Haiti em praticamente todo o período de seus dois mandatos, iniciando-se em 2004 com a polêmica decisão de liderar a Missão das Nações Unidas para Estabilização do Haiti (MINUSTAH), irrompendo no subsequente desenvolvimento de projetos de cooperação, nunca antes realizados de maneira sistemática no histórico das relações diplomáticas entre os dois países.

Dentre as razões para a escolha do Haiti como estudo de caso, essa foi sem dúvida a mais importante, pois permite observar as preferências políticas do presidente de modo mais tangível, uma vez que ao contrário das relações que, em maior ou menor escala, já

\footnotetext{
${ }^{1}$ Embora adote-se neste trabalho uma perspectiva institucional para o entendimento das decisões que são tomadas na política externa, não se deixa de considerar sua limitação metodológica que, se não exclui de todo, pelo menos não trata com a devida precisão fatores como os interesses de grupos apartados da arena política, ou mesmo ambições mais gerais circunscritas ao cenário internacional, como aquela que frequentemente discute-se, de que Lula tinha como objetivo, ao aceitar a liderança da MINUSTAH garantir para o Brasil tão somente um assento permanente no Conselho de Segurança da ONU (CSNU).
} 
existiam com o Continente Africano ou a América do Sul, o Haiti nunca estivera com tanto empenho sob o radar do governo brasileiro, o que fez com que a participação na MINUSTAH se constituísse em um dos marcos mais importantes na história da PEB (Hirst, 2012).

Um outro fator decisivo para essa escolha foi um certo incômodo causado pela postura quase filantrópica no tratamento da questão haitiana por parte do governo brasileiro, por vezes revelada através dos discursos do próprio presidente e de outras autoridades, para os quais o caráter humanitário da missão excluía a existência de quaisquer outros interesses. A questão que se colocava era: visto que também houve um crescimento no volume de CT realizada com o Haiti, em que aspectos ela é diferente daquela empreendida com os demais países do eixo sul? É possível que esta tenha sido a pergunta certa à motivação errada, que era a de compreender o processo decisório da CTPD; mas o fator crítico continuou a girar em torno da inquietante dúvida de como uma cooperação de caráter humanitário poderia ser ao mesmo tempo técnica.

O que foi tornando-se claro ao longo da pesquisa, entretanto, e reforçou a importância em estudar o Haiti - para além das já conhecidas discussões relacionadas à MINUSTAH -, em um contexto marcado pela valorização política da CSS, foi que os dois tipos de cooperação, embora possuam natureza e objetivos diferentes, não se excluíam naquele caso específico. Quando do início da Missão, o governo brasileiro de pronto reconheceu o reduzido poder institucional que o país caribenho possuía, o que fazia com que ele estivesse sujeito à contínuas intervenções externas na gerência de suas questões políticas, econômicas e sociais, de modo que se fazia necessário um fortalecimento de sua capacidade em solucionar seus próprios problemas. Os pilares da CT brasileira, por sua vez, iam justamente de encontro a essas necessidades, ao mesmo tempo em que as assimetrias de recursos entre os dois países, fazia emergir uma configuração mais humanitária, a qual o Brasil, desde o início, recusou-se a chamar de ajuda, mas sim de cooperação. Assim, ao mesmo tempo em que se empenhou na doação de alimentos, medicação e envio de equipes brasileiras na tentativa de sanar os problemas mais urgentes no Haiti, ele passou a assinar acordos de cooperação que previam a transferência de recursos humanos e técnicos para minimamente dotar o país de autonomia. 
Ainda que estes questionamentos tenham sido fundamentais para a escolha do estudo de caso, não foram em si os precursores da questão teórica mais ampla com o qual a dissertação preocupa-se. Ao invés disso, o problema esteve desde o início envolto no processo de tomada de decisão que orienta a política de CTPD, ora a partir do presidente, conforme mencionado ora dos ministérios, o que parte da literatura convencionou chamar de horizontalização de competências que, em última instância, dotaria diferentes ministérios de prerrogativa para atuar em política externa, quebrando a exclusividade até então conferida ao MRE.

Neste sentido, dois grandes obstáculos foram encontrados pela pesquisa: i) a existência de poucas referências teóricas que tratem a CTPD a partir de seus aspectos políticos e não apenas descritivos, em grande medida resultado das incipientes discussões a esse respeito; e ii) as inconsistências de dados sistematizados sobre a CTPD, sobretudo aquela que se realizou com o Haiti no período analisado. Em relação a este último, as informações estão disponíveis, em sua maioria, nos sites do MRE - que oferece um rico banco de dados para a consulta pública dos atos internacionais - e da $\mathrm{ABC}$ - que organiza os projetos realizados e recebidos pelo governo brasileiro. No entanto, isso não significa que elas estejam completas, já que ao longo da pesquisa qualitativa foi possível detectar algumas discrepâncias entre os dados fornecidos por eles e aquilo que as secretarias do MS informam. De qualquer forma, buscou-se contornar este problema a partir de contínuas comparações e verificações, para que fossem contempladas todas as iniciativas jurídicas e políticas de CTPD às quais se teve acesso, a fim de formular um quadro síntese o mais completo possível.

Pode-se dizer que esse entrave, por outro lado, é também fruto das incertezas que ainda existem em relação à prática dessa política, pois de acordo com um representante do MRE, serão necessários mais tempo e mandatos para ser possível definir se e como a política de CSS brasileira será desenvolvida, para que então, sejam feitas afirmativas sólidas sobre seus arranjos institucionais e informacionais. Conquanto persistam as dúvidas, é importante deixar claro que não se pretende aqui criar postulados no que diz respeito ao envolvimento dos ministérios na política de CTPD, tanto para o período estudado, como para os dias correntes, dado tratar-se de um estudo exploratório consciente de que os próprios quadros do governo não possuem ainda absoluta clareza 
em relação à sua organização e gestão, embora concordem com seu contínuo amadurecimento neste sentido.

Outrossim, não restam dúvidas de que essas incertezas política-institucionais contribuíram enormemente para que fosse concedido grande espaço para a atuação de atores responsáveis por diferentes segmentos setoriais da política pública brasileira e que, por seu turno, empreendem hoje essa prática, individual ou coletivamente, através de suas respectivas experiências a fim de replicar nos países cooperantes seus respectivos modelos de desenvolvimento social, tornando indispensáveis a presença do ministérios.

Feitas as devidas ressalvas, o foco principal recairá então, em observar, de que modo eles movem-se neste jogo, pois compartilha-se com Pinheiro e Beshara (2011) o reconhecimento de que, embora eles não possam ser caracterizados como unidades decisórias de política externa per se, com poderes equivalentes ao do presidente, haja visto não possuírem um grau de autonomia necessário para tal, seu papel não pode ser diminuído ao de simples implementadores de políticas, visto que eles têm hoje cada vez mais poder na agenda internacional.

Esses questionamentos necessitam de uma imersão nos estudos sobre a atuação política das burocracias estatais para além daqueles feitos pela literatura sobre política externa. Encontrar as raízes dos atuais trabalhos sobre o tema e entender como ele é analisado pelos principais autores da área, é uma das principais tarefa a ser executada. A abordagem adotada pelo trabalho é a teoria do principal-agente, que aponta que diante das muitas e diversificadas tarefas exercidas pelos Estados Modernos, grande responsabilidade pela formulação e implementação de políticas tem sido delegada aos quadros burocráticos do governo, sem que isso, no entanto, cause prejuízo à autoridade exercida pelos líderes políticos.

Concorda-se com a premissa de que qualquer alegação que ultrapasse este limite, é um exagero proveniente da ansiedade oriunda de uma mitologia política presente em alguns países que credita à burocracia um poder maior do que aquele que ela realmente tem (Rourke, 1976; Hammond, 2003). Assim, a discussão encontra-se ancorada no pressuposto que sustenta que os diferentes graus de autonomia que vão se consolidando em torno de uma burocracia são reflexos diretos da política que está em pauta, ora sendo 
alterada ora implementada, e também do envolvimento ou não do presidente neste processo. Acredita-se que este pressuposto teórico proveniente da Ciência Política, dialogue com os trabalhos de Krasner (1972) e Rosati (1981), já na seara de estudos da APE, o que proporciona uma análise conjunta do papel do presidente e dos ministérios, a partir da observação da delegação das tarefas e de como ela contribuiu para que se tornasse possível o aumento das competências das burocracias na CTPD.

Assim, foram levantadas duas principais hipóteses. A primeira delas, já comentada anteriormente, é a de que Lula foi o ator responsável pelo estabelecimento de uma agenda política de cooperação técnica com o Haiti, contextualizada pelo fortalecimento da Cooperação Sul-Sul (CSS), que se denominou aqui de fase política-jurídica da CTPD. Para testá-la, foi empregado o modelo teórico do Ponctuated Equilibrium (Baumgartner e Jones; 1993) para verificarem-se dois pontos: i) a importância que Lula atribuiu à CTPD no período correspondente aos seus dois mandatos (2003-2010) para tornar empiricamente válida a afirmação de que os presidentes são atores destacados para a definição do agenda-setting e ii) se mudanças institucionais - ainda que não se ignore contextos socioeconômicos - influenciam, de fato, na análise de períodos históricos no que tange à adoção de políticas. Não obstante, esta hipótese pode ser desdobrada na premissa de que a delegação de poderes por parte do presidente, é tão somente realizada mediante a garantia de mecanismos de controle, que asseguram ao principal que seus interesses serão respeitados, a qual, por sua vez, será testada mediante análise do processo de nomeação dos ministros da saúde durante os dois mandatos de Lula, e a comparação das competências do ministério estabelecidas nos decretos presidenciais e nos regimentos internos do MS, em 2003 e 2010.

A segunda hipótese é a de que este tipo de política apenas pode ser realizado a partir da delegação de poderes aos ministérios, correspondente à sua fase política-técnica. Ela será, ou não, validada a partir do estudo de caso da cooperação técnica empreendida pelo MS no Haiti utilizando, além das entrevistas realizadas com o MRE e o MS, os substratos de duas ferramentas empíricas: i) a análise qualitativa dos atos internacionais e documentos de projetos de CTPD, no que diz respeito às atribuições de competências nas fases jurídica e política presentes no momento de suas assinaturas, bem como a autoridade do Executivo Federal, responsável por sua celebração; e ii) o emprego do modelo analítico de França e 
Badin (2010) e Silva et al. (2010) para dimensionar a prerrogativa outorgada aos Ministérios para lidarem com as questões internacionais.

França e Badin (2010) utilizaram como fonte de dados a regulamentação infraconstitucional, formada pelos decretos que aprovam a estrutura regimental dos órgãos do Poder Executivo Federal e as portarias ou anexos dos próprios decretos e também os regimentos internos desses órgãos, consultados em julho de 2008. Eles incluíram no âmbito da administração direta os Órgãos de Assistência Direta e Imediata (OADI), compostos pela Secretaria Executiva, pelo Gabinete do Ministro e pela Consultoria Jurídica e os Órgãos Específicos Singulares (OES) compostos pelas Secretarias de Estado, chegando à conclusão de que alguns Ministérios chegam a possuir até $50 \%$ de sua estrutura vinculada à temas internacionais.

Silva et al. (2010), por sua vez, desenvolveram trabalho com metodologia semelhante, com qual a pesquisa dialoga mais intimamente, uma vez que, analisando os decretos que estabelecem a estrutura regimental dos Ministérios, Secretarias e Conselhos que compõem o Executivo, para o ano de 2008, foi incluído também conteúdo empírico sobre como ocorre o processo decisório em política externa no interior destes ministérios, destacando-se as fases de formulação e implementação, identificadas a partir da análise destes documentos.

\section{Metodologia}

A pesquisa contou com dois momentos de análise. No primeiro foi feito o levantamento bibliográfico sobre temas pertinentes ao projeto, sendo centrais, mas não exclusivos, dois deles: os estudos sobre burocracias nos campos da Ciência Política e da APE, sobretudo no que diz respeito ao envolvimento das mesmas no processo de tomada de decisão e implementação de políticas; a CTPD empreendida pelo governo brasileiro com o crescente aumento da participação das burocracias de diferentes ministérios e também como isso ocorreu no caso particular do Haiti; e consulta à fontes jornalísticas para tratar de eventos políticos circunscritos ao recorte temporal aqui adotado.

Para delinear o perfil da cooperação técnica, utilizou-se publicações e dados disponíveis online por Agências e Ministérios, tais como: as preposições de Acordos de Cooperação 
enviadas pelo poder Executivo entre os anos de 1970 e 2010, disponíveis no site do Congresso Nacional; os Acordos de Cooperação celebrados entre Brasil e Haiti, e/ou terceiros países/organizações, disponíveis no Sistema de Atos Internacionais (SCI) do MRE; o banco de dados de projetos de Cooperação Sul-Sul com o Haiti encontrado no site da Agência Brasileira de Cooperação (ABC); os nove Decretos Presidenciais que autorizaram a Estrutura Regimental e Quadro Demonstrativo dos Cargos do Ministério da Saúde editados entre 2003 e 2010, disponíveis no site do Congresso Nacional; os Regimentos Internos e Organogramas Básicos do Ministério da Saúde para os anos de 2003 e 2010, disponíveis no site da Biblioteca Virtual em Saúde do MS; além de material impresso e/ou digital disponibilizados por este último.

No segundo momento foram realizadas entrevistas em profundidade com os principais atores envolvidos na referida política, a saber: MRE e MS. Foi feita uma entrevista com a responsável pelo programa de cooperação bilateral entre o Brasil e o Haiti da Agência Brasileira de Cooperação (ABC), em 10 de setembro de 2014; com o diplomata responsável pela Coordenação Geral de Combate à Fome do Itamaraty (CGFome) em 22 de outubro de 2014; e com um representante da Secretaria-Executiva do Ministério da Saúde, lotado no Departamento de Economia da Saúde, Investimentos e Desenvolvimento (DESID), responsável por coordenar a CTPD com o Haiti, em 26 de fevereiro de 2015.

O desenho inicial da pesquisa, contava ainda com entrevista a ser realizada com a Assessoria de Assuntos Internacionais do Ministério da Saúde (AISA/MS), contato o qual, o interlocutor entrevistado anteriormente no Ministério havia se disponibilizado em efetivar. Entretanto, o fim do primeiro prazo limite para a cooperação com o Haiti, fixado para o primeiro semestre daquele ano, resultou em seguidas viagens da equipe do MS envolvida com a CTPD no Haiti, processo que permaneceu indefinido até meados do segundo semestre, momento em que era redigido o texto para exame de qualificação da pesquisadora. 
Em relação à essas entrevistas, não serão utilizados trechos de falas dos interlocutores, nem mesmo divulgados seus nomes, dadas as garantias de confidencialidade conferidas aos mesmos através da assinatura do Termo de Consentimento para a sua realização. Outrossim, seu conteúdo auxiliará na constituição de um quadro mais claro no que diz respeito às suas respectivas atividades, complementando a pesquisa bibliográfica e documental aqui empregada, de modo que, não serão feitas análises exaustivas a partir delas.

A dissertação está estruturada em três capítulos, além desta introdução e da conclusão, cabendo ao primeiro um estudo aprofundado sobre as teorias supracitadas a fim de deixar claro como os pressupostos da pesquisa dialogam com a literatura sobre o tema, construindo os alicerces para a pesquisa empírica. Assim, o capítulo está dividido em duas partes, uma na qual será feito, através da literatura internacional, levantamento bibliográfico sobre burocracias domésticas e o problema da delegação, replicando na sequência essa mesma discussão para o campo da APE; na outra, buscar-se-á verificar como o caso brasileiro e insere-se nestas análises.

O segundo capítulo buscará verificar como o conceito e a prática da CTPD emergem a partir do desenvolvimento da Cooperação Internacional para o Desenvolvimento (CID). Posteriormente, será descrito como este processo desenvolveu-se no Brasil, desde a década de 1970 até final de 2010, por meio do emprego do modelo teórico do Ponctuated Equilibrium de Baumgartner e Jones (1993), para testar a hipótese de que o presidente é o principal motor no estabelecimento da agenda-setting utilizando-se do levantamento quantitativo das proposições de Acordos de Cooperação enviados pelos presidentes ao Legislativo. Feito isso, o foco recairá sobre a observação dos arranjos institucionais de distribuição de poder, que permitiram aos Ministérios atuarem tanto na formulação como na implementação da CTPD no caso específico do Haiti, através de informações provenientes do banco de dados de atos internacionais do MRE e aqueles sobre os projetos disponíveis no site da $\mathrm{ABC}$, que permitirão analisar as questões que versam sobre suas bases legais de execução.

O capítulo três terá como objetivo adentrar, enfim, no objeto de pesquisa da dissertação, qual seja, a CTPD empreendida pelo MS no Haiti, a partir do estudo de caso do Projeto de Cooperação Sul-Sul de Fortalecimento da Autoridade Sanitária do Haiti, a partir do 
qual serão levantadas informações a respeito do processo decisório que se estabelece entre as diferentes secretarias - e seus respectivos órgãos - que se encontraram envolvidos no referido projeto.

Em um primeiro momento buscar-se-á operacionalizar os conceitos de centralização e partidarização provenientes dos estudos de delegação, enquanto mecanismos de controle ex-ante, utilizados por Lula para garantir que os ministros da saúde implementassem políticas alinhadas ao seu programa de governo. Deste modo, serão explorados, além dos perfis técnico e político desses gestores e dos embates ocasionados pela pressão política intrínseca ao regime presidencialista de coalização adotado no Brasil, a análise dos decretos presidenciais que regem a estrutura regimental do MS, bem como seus regimentos internos. Na sequência, será feito o reconhecimento das competências atribuídas a este ministério para o projeto em questão, utilizando o modelo de Silva et al. (2010), para verificar de que forma ele está estruturado, bem como quais são os órgãos que desempenharam funções na CTPD com o Haiti, evidenciando, desta forma, o ciclo das fases para o estabelecimento da política de CTPD em que pese sua etapa políticajurídica (Ato Internacional) e política-técnica (Documento de Projeto). 


\section{CAPítUlO 1. ABORDAGENS TEÓRICAS PARA O ESTUDO DAS BUROCRACIAS ESTATAIS E SUA ATUAÇÃO EM POLÍTICA EXTERNA}

A importância atribuída ao papel desempenhado por diferentes atores domésticos na consecução da política externa dos Estados foi, e continua sendo, um profícuo campo de estudos para investigadores da área de Ciência Política e Relações Internacionais (Allison, 1971; Putnam, 1988; Risse-Kapen, 1995; Milner, 1995; Hudson and Vore, 1995; Hudson, 2005; Carlsnaes, 2002; Kaarbo et al. 2001). O pressuposto comum a estes autores é o de que os elementos internos aos Estados, tais como suas políticas públicas, burocracias, atores, agendas e grupos, são indispensáveis para a investigar a razão pelas quais determinadas decisões são tomadas, e como impactam a agenda externa dos países.

O presente capítulo tem como objetivo tratar precisamente dessa questão a partir da observação dos atores que integram o Poder Executivo, a saber, o presidente e as burocracias ministeriais. Embora tenha sido atribuída grande importância ao tema nos últimos anos no interior campo de Análise da Política Externa (APE), sobretudo a partir do famoso estudo de Graham Allison (1971), - que tratou da imbricada rede estabelecida entre o presidente e suas burocracias na política externa norte-americana no contexto da crise dos mísseis cubana de 1962 - no Brasil, só muito recentemente o papel desempenhado pelos ministérios na política externa tem ganhado relevância empírica nas agendas de pesquisa de Ciência Política e Relações Internacionais (Cason e Power, 2009; França e Badin, 2010; Silva et al., 2010; Cepik e Sousa, 2011; Lopes, 2011; Pinheiro e Beshara, 2011; Pimenta de Faria, 2012b; Albuquerque, 2013; Milani, 2014).

Isso pode ser explicado por dois principais fatores. O primeiro diz respeito ao conhecido debate sobre o insulamento burocrático do Ministério das Relações Exteriores (MRE), ou Itamaraty, que por sua vez, sempre tornou os temas de política externa restritos à esta instituição, sem que chegasse a despertar grande interesse de outros grupos domésticos (Cason e Power, 2009; Lopes, 2011; Pimenta de Faria, 2012a). O segundo, diretamente relacionado ao primeiro, está atrelado à histórica diferenciação entre política externa e política pública, que atribui diferentes status à cada uma delas ao dispensar à primeira a exclusiva responsabilidade sobre o tratamento de questões de defesa nacional e comércio internacional, e à segunda os demais assuntos setoriais de preocupação doméstica. 
Entretanto, em razão das diversas transformações ocorridas no cenário internacional nos últimos anos, fica mais claro que a interdependência entre elas tornou-se cada vez maior, de forma que muitas vezes o comportamento de uma se dá pelo entendimento da outra. No Brasil, particularmente, este quadro foi amplamente evidenciado a partir dos anos 2000 com a emergência da Cooperação Técnica entre Países em Desenvolvimento (CTPD), no âmbito da Cooperação Sul-Sul (CSS) que apresentou ao país um rearranjo do escopo de sua atuação externa, com grande destaque para a internacionalização de suas políticas setoriais para diferentes países do eixo Sul, o que por sua vez, exigiu de seus ministérios, e de suas burocracias, maior inserção internacional. Não obstante os avanços dessa agenda de pesquisa, pouco tem sido tratado sobre essa questão do ponto de vista da ação da política burocrática.

O que algumas recentes agendas de pesquisa indicam é que tem havido uma maior atribuição de competências aos diferentes ministérios para lidarem com questões internacionais a partir de suas respectivas competências, e uma vez conferida autonomia a estes atores para tratar da política externa, pode ocorrer nesta, tanto quanto ocorre nas demais políticas públicas, a possibilidade de uma maior dificuldade de gestão por parte do presidente no que diz respeito àquilo que é proposto e implementado (França e Badin, 2010; Silva et al., 2010; Cepik e Sousa, 2011).

Isso remonta ao problema levantado pelos estudos da delegação, o qual vem sendo continuamente discutido pela literatura em Ciência Política, que partem do pressuposto de que existe uma relativa transferência de autoridade por parte de um ator (principal) para um outro (agente), a fim de que as políticas públicas, possam não apenas ser implementadas, mas também formuladas de modo satisfatório aos interesses do primeiro, que por não possuir os recursos necessários (amplo conhecimento e tempo), delega àqueles que os detém para que possam tratar das questões que se colocam em determinado contexto (Neustadt, 1960; Weingast\& Moran, 1983; Moe, 1984; King, 1993; Moe, 1993; Bawn, 1995; Epstein andO'Halloran, 1994; Moe and Wilson, 1994; Lupia, 2001; Carpenter, 2001; Howelland Lewis, 2002; Hawkins et al., 2006; Lewis, 2007; Burke, 2016). Entretanto, por tratar-se de um fenômeno relativamente recente no Brasil, existem poucos estudos que abordam o problema da delegação em política externa, e por isso fazse necessário observar como ocorre este processo. 
Diante da escassez de estudos sobre o impacto da ação burocrática sobre a agenda de política externa, o que resulta na carência de elementos explicativos particulares para a discussão da questão na universidade, e partindo do pressuposto de que a política externa é também uma política pública, o trabalho lança mão da literatura sobre burocracia pública desenvolvida no campo da Ciência Política para a APE, a exemplo do que foi feito por Silva et al., (2010). Assim, o capítulo está dividido em duas partes. Na primeira, será feito o levantamento bibliográfico da literatura internacional sobre burocracias domésticas e o problema da delegação, bem como esta questão aparece nos estudos de APE. Na segunda, o enfoque recairá particularmente sobre o caso brasileiro nos âmbitos doméstico e externo.

\section{Burocracia e Política}

Os atuais Estados Modernos são responsáveis por inúmeras tarefas envolvendo alto grau de complexidade, que vão desde a provisão de serviços até a regulação de determinadas atividades privadas, de modo que grande parte delas foram delegadas ao escrutínio da ação burocrática. Embora elas tenham se tornado um importante ator no cenário político no último século, pouca atenção tem sido de fato conferida aos aspectos administrativos dos governos e suas implicações políticas, ao contrário do que tem ocorrido com os estudos sobre competição eleitoral, partidos e sistemas partidários, e o papel do poder legislativo. Este quadro implica, entre outras coisas, na falta de ferramentas analíticas, de base teórica e conceitual, que sejam suficientemente capazes de oferecer uma base de sustentação para análises sobre a administração pública e a política burocrática ${ }^{2}$, bem como sobre o papel que as burocracias exercem sobre a esfera propriamente política (Fernandes, 2010; 2013). Há duas razões para essa lacuna.

A primeira alude ao fato de que, historicamente, a emergência das burocracias fez parte de um processo mais amplo de desenvolvimento do aparato dos Estados Nacionais modernos, em torno do qual gravitava uma ideologia democrática que advogava pela importância da separação dos poderes Legislativo, Executivo e Judiciário. O objetivo era evitar a concentração de poder bem como seu abuso pelos atores/instituições envolvidos.

\footnotetext{
2 "Política Burocrática" é um termo que se refere ao papel político que as burocracias desempenham nos Estados Modernos. Seus aspectos conceituais serão desenvolvidos com maior detalhamento ao longo da dissertação.
} 
Neste sentido, ao Executivo caberia o papel correspondente à liderança política, desempenhando por um lado, funções políticas e por outro, administrativas, sendo que estas últimas deveriam sempre atuar em consonância com os objetivos dos primeiros, ao passo que a divisão do trabalho evitaria disputas entre os atores reunidos neste grupo. Para assegurar que esta prerrogativa fosse respeitada, entretanto, foram desenvolvidos arranjos constitucionais, de modo que se tornou lugar-comum na teoria política e constitucional o pressuposto de que funcionários do governo desempenham um papel meramente instrumental.

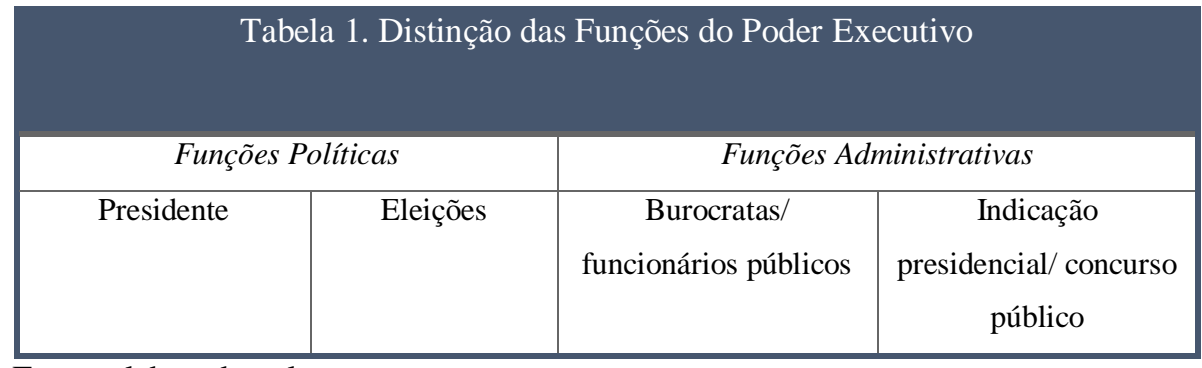

Fonte: elaborado pela autora

Ainda a esse respeito, para Rourke (1976), em muitos aspectos, para além das decisões presidenciais, o processo de tomada de decisão que ocorre nas agências do poder Executivo, tende a se confundir com aquele que se dá nas assembleias legislativas. A semelhança mais importante é que, assim como os legisladores, os burocratas também atuam sob um contexto de barganhas e de ajuste de conflitos de interesses, o que os leva, frequentemente, a adotarem e/ou modificarem políticas de forma "incremental", segundo a teoria de Charles E. Lindblom (1959), evitando desta forma o alcance de inovações muito radicais que possam abalar ou mesmo comprometer programas já existentes. Isso poderia ajudar a explicar, em parte, a pouca visibilidade das decisões políticas advindas deste grupo.

Outrossim, existem pelo menos três diferenças principais entre essas duas esferas do poder governamental: i) a autoridade das burocracias é hierarquicamente estruturada; ii) a influência profissional e técnica são as principais variáveis de distinção do critério político para a tomada de decisão e, iii) o fato do processo político burocrático não ser amplamente publicizado como ocorre no Legislativo. Para Lindblom (1959): “The bureaucratic policy process is, by way of contrast, a quite invisible part of government. The environment of bureaucracy is a cloistered sanctuary as compared with the limelight 
of publicity in which a legislative assembly normally operates" (p. 136). Deste modo, reuniões, negociações e, consequentemente, decisões que ocorrem nos corredores das burocracias não chegam ao público, ao menos que seja possibilitado algum tipo de acesso a essas informações.

A dificuldade de acesso à tomada de decisão nos gabinetes é o que, em grande medida, ocasiona a falta de ferramentas teóricas e conceituais que possam guiar pesquisas que se debruçam sobre o tema. No entanto, isso não quer dizer que seja inviável a produção de trabalhos neste campo, uma vez que diferentes análises, como as que se buscará aqui apresentar, operam sob esta perspectiva e tem alcançado resultados importantes que demonstram como as burocracias atuam também na arena política.

Atrelada a esta primeira, - da separação histórica dos poderes Legislativo, Executivo e Judiciário - tem-se a segunda razão, que não obstante, encontra-se em uma relação causal com o que foi até aqui apresentado e diz respeito ao fato de que, adotando esse foco de análise, ficaria relegada às burocracias uma caracterização pautada puramente em seus elementos técnicos como a implementação de políticas públicas. Essa caracterização, entretanto, vem sendo recentemente desafiada pela observação empírica - acadêmica e profissional - de que questões como o controle de informações técnicas e o alto grau de influência e expertise, entre outras, têm tornado os burocratas importantes atores que participam do processo político (Rourke, 1976; Meier e Krauser, 2003; Krauser, 2003; Hamond, 2003).

Um dos aspectos a ser destacado é o monopólio da informação pelas burocracias, cada vez mais entendido como sinônimo de poder. Ele garante aos burocratas grande chance de influenciar os processos políticos em áreas nas quais eles detém conhecimento. Atrelado a este fator qualitativo, aparece outro quantitativo que diz respeito ao fato de que existe um grande número de burocracias, e por isso podem ocupar muitas e diferentes posições nos governos, tornando-as passíveis não somente de moldar as técnicas, mas também políticas que se apresentem como viáveis, cabendo inclusive o poder de implementá-las ou não (Figueira, 2009).

Aceitando esse pressuposto de dupla atuação, Rourke (1976) aponta que nas sociedades modernas, independentemente de serem ou não democráticas, a principal fonte de poder 
das burocracias repousa justamente na expertise que ela detém. Isso quer dizer que, atuando na arena política, as competências creditadas aos burocratas podem ser observadas em dois momentos fundamentais: um no processo de tomada de decisão - de mais difícil observação - e outro na execução (implementação) dessa última.

Entretanto, o que se pretender dizer exatamente quando se fala em um processo de "tomada de decisão"? O trabalho parte do pressuposto de que tomar uma decisão significa escolher uma dentre diferentes alternativas a um problema $X$, de modo que esta opção determine o curso de ação a ser empreendido para se obter o resultado esperado $Y$, ou seja, diz respeito às escolhas feitas mediante certo grau de incerteza pelos decisionmakers, ou tomadores de decisão. Diferentes abordagens tratam desta questão em particular, sendo que grande atenção é conferida àquelas de recorte crítico, mais interessadas em discutir a tradicional abordagem racionalista que se caracteriza pela ponderação dual entre custos e benefícios.

A teoria da escolha racional, como é conhecida, entrou no campo da Ciência Política a partir das abordagens da Teoria Administrativa, - francamente influenciada pelas modificações ocorridas em função do desenvolvimento da economia ${ }^{3}$. A decisão racional é entendida como um processo através do qual os indivíduos ou organizações buscam maximizar seus recursos através do ajustamento consciente dos meios e dos fins, partindo do pressuposto de que todos os custos relevantes que estão envolvidos nas transações são conhecidos de antemão. É possível dizer, entretanto, que essas teorias são melhor compreendidas a partir de seu caráter normativo do que como teorias positivas, pois dificilmente os atores reais diante de situações cotidianas comportam-se verdadeiramente à luz do que é prescrito por elas (Ferejohn e Pasquino, 2001).

Simon (1980) é um dos primeiros autores a debater esse ponto. Para ele o ideal da escolha racional não pode ser amplamente alcançado em razão da insuficiência de informações bem como do elevado custo para obtê-las -, e da carência de habilidades individuais, estando esta última relacionada à limitação da capacidade humana em processar uma grande quantidade de informação. Este quadro leva o autor à ideia de uma racionalidade limitada, em que a tomada de decisão é feita mediante um conjunto de comportamentos

\footnotetext{
${ }^{3}$ Para uma discussão desses autores à luz da teoria da escolha racional, ver Hindmoor (2006).
} 
e ações que são guiados pela opção considerada a mais satisfatória pelos decision-makers, que não necessariamente corresponde à opção ótima.

“[Herbert Simon] (...) postulou o chamado mundo de racionalidade limitada onde os conceitos de maximização ou otimização do comportamento foram substituídos pela ideia de comportamento satisfatório. [Ele] baseia [-se] na ideia de que a tomada de decisão dos políticos a partir da elaboração de uma matriz com todas as alternativas disponíveis, os prós e contras, prevendo todas as possibilidades de resultados esperados para depois decidir é frágil. Para o autor, as unidades de decisão examinam sequencialmente as opções disponíveis até encontrarem uma que apresente uma solução suficiente e, de modo consensual, satisfatória que lhes permita agir" (Siqueira, 2011; p. 11).

A limitação da racionalidade permite compreender que a ausência de amplos recursos informacionais e a limitada capacidade cognitiva dos decision-makers, - que Simon (1980) chama de "falta de onisciência" - geram certa inabilidade no cálculo das consequências exógenas a serem enfrentadas a partir da escolha de determinada decisão; por sua vez, isso impede que haja grandes oscilações nas políticas em curso, já que os custos políticos com os quais os atores deverão arcar no caso da opção por uma decisão ineficaz, ou mesmo impopular, são muito altos.

Lindblom (1959), por sua vez, questionou a ênfase dada ao racionalismo por Simon (1980), propondo a incorporação de variáveis como eleições, burocracias, partidos e grupos de interesse para compreender a formulação e implementação de políticas. $\mathrm{O}$ autor é reconhecido como o fundador da Teoria Incremental, que busca demonstrar que, na prática, as políticas públicas são formuladas e implementadas muito mais por meio de comparações limitadas sobre os temas que estão sendo analisados, do que por mudanças bruscas das quais não se pode prever os resultados, ao passo que se um grande erro é cometido, a reversão pode ser muito difícil. Os não-incrementalistas, por sua vez, refutam esta ideia, apontando para a incapacidade da abordagem em lidar com grandes mudanças ocorridas em determinas políticas.

Neste sentido, segundo Robinson (2007), pesquisas mais recentes têm focado em variações temporais, analisando por exemplo, por que os Estados adotam determinadas políticas públicas em alguns momentos e em outros não. Embora ele reconheça que o interesse na dinâmica temporal não seja nova, argumenta que o modelo do Ponctuated Equilibrium, na década de 1990, foi a fonte propulsora dessa mudança, com capacidade 
de agrupar as abordagens incrementalistas e não-incrementalistas, conforme será tratado na sequência.

\subsection{O Estabelecimento do Agenda-Setting}

O pressuposto de que a inclusão de uma determinada política pública na agenda do governo é o primeiro estágio definidor para sua consecução sugere que ela está inserida em um ciclo. Esta tipologia entende a política pública enquanto um ciclo deliberativo que é formado por diferentes estágios, constituindo-se em um processo dinâmico. O ciclo da política pública, como é conhecido, não é estanque e nem único, ao passo que diferentes autores criaram modelos que se distinguem em função dos estágios presentes (Baptista e Rezende, 2015).

De modo geral, pode-se dizer que o ciclo da política pública é constituído dos seguintes estágios: i) definição de agenda ou agenda-setting; ii) identificação de alternativas; iii) avaliação das opções; iv) seleção das opções; v) implementação e vi) avaliação (Souza, 2006b; Baptista e Rezende, 2015).

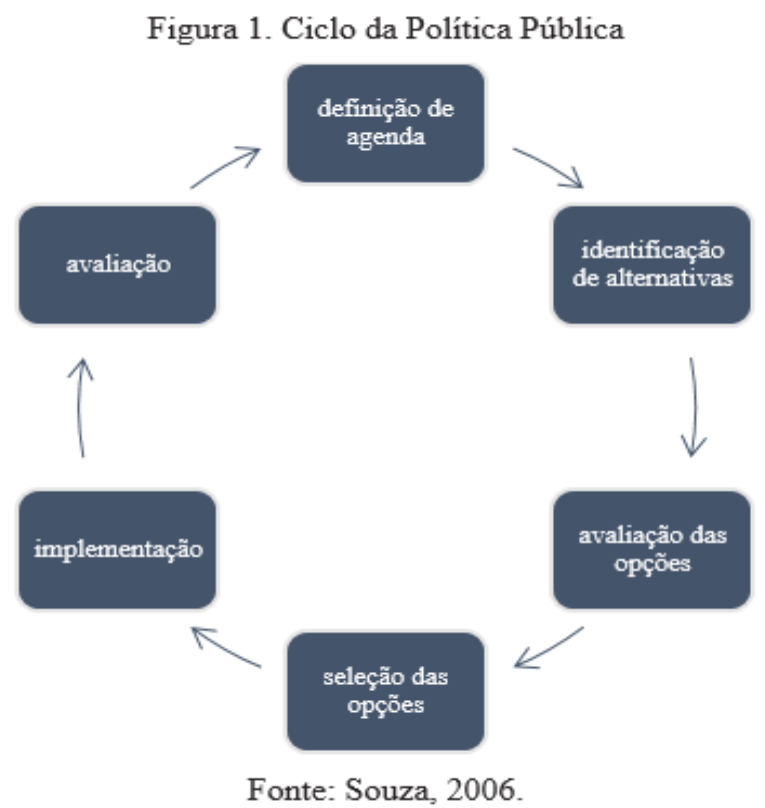


De acordo com Souza (2006b), este tipo de abordagem enfatiza o agenda-setting. Ela busca reconhecer na prática quais são as questões importantes em determinados momentos e como e por que elas passam a integrar o corpo de políticas públicas. A essas perguntas, existem três respostas. Na primeira, o foco recai sobre o reconhecimento e definição de problemas. A segunda resposta, que focaliza a política, busca entender como a consciência coletiva acerca da necessidade de se enfrentar determinado problema é constituída, sendo que esta construção pode acontecer via processo eleitoral, mudanças nos partidos ou ideologia. A terceira, por sua vez, focaliza os atores que participam do processo de definição e implementação das políticas públicas.

Em relação a estas três respostas, sobretudo à última, cabe destacar dois modelos conhecidos, o Ponctuated Equilibrium, de Baumgartner e Jones (1993) e o Multiple Streams, de Kingdon (2006). Embora partilhem o mesmo problema e algumas similaridades, os modelos possuem características distintas, de modo que não é possível descrevê-los integralmente, pois não é esse o foco central do trabalho. Por isso, é ressaltado um importante elemento comum a ambos: a diferenciação de competências dos atores envolvidos. Além disso, atenção especial é dada ao segundo modelo, devido à sua importância explicativa para estudo de caso a ser desenvolvido nos capítulos subsequentes.

A começar por Kingdon (2006), o autor considera três importantes processos para a formação de políticas: o estabelecimento de uma agenda, as alternativas para a formulação das políticas e a implementação da decisão. De acordo com seu modelo, embora os processos nem sempre sigam essa ordem, primeiro os atores reconhecem determinado problema, geram propostas a ele e procuram defender e implementar determinadas políticas, consideradas as mais satisfatórias. Não obstante, ele reconhece que embora os campos de atuação não sejam fixos - e isto é importante ser sublinhado na prática é possível identificar a presença de diferentes participantes em cada um destes processos, que para fins operacionais, ele dividiu em dois grupos, o de atores visíveis e o de invisíveis.

O primeiro grupo é composto por aqueles mais perceptíveis na arena política, como o presidente e seus assessores de alto escalão, importantes membros do Congresso, grupos de interesse, a mídia e outros relacionados ao processo eleitoral, como os partidos 
políticos e os comitês de campanha, enquanto no segundo figuram os acadêmicos, burocratas de carreira e funcionários do Congresso. Segundo o autor, o grupo de atores visíveis, sobretudo o presidente, detém o poder de definição da agenda sem, no entanto, conseguir, necessariamente, exercer o mesmo poder sobre a escolha de alternativas, que fica a cargo do outro.

Para ele, entretanto, estes diferentes atores integram uma esfera política que funciona independentemente do reconhecimento de um problema ou do desenvolvimento de propostas e opera a partir de dinâmicas e regras próprias, de forma que ele atribui grande importância ao ambiente institucional como importante formador de agenda. Um novo governo pode, por exemplo, mudar a agenda a partir da ênfase dada às suas próprias concepções acerca dos problemas e suas respectivas propostas, buscando negociar um consenso com os demais atores.

Figura 2. Competência dos atores de acordo com Kingdon

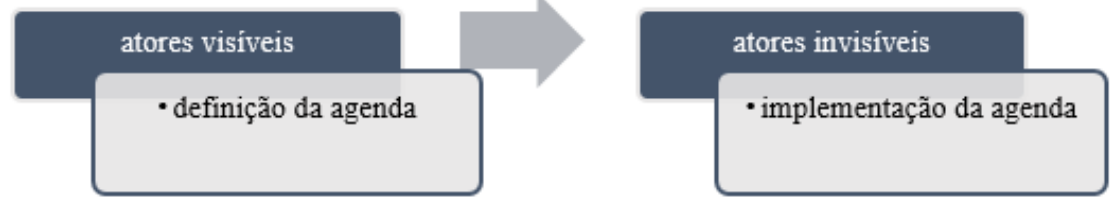

Fonte: Adaptado de Kingdon, 2006.

Baumgartner e Jones (1993) e Baumgartner et al. (2007), em uma perspectiva semelhante, também estão preocupados com a formação da agenda política, de forma que a teoria proposta mobiliza dois elementos importantes que se relacionam e dão forma ao modelo: i) a definição das questões e da agenda e ii) as estruturas institucionais. Eles partem do pressuposto de que as questões apresentam-se no discurso político através de imagens ${ }^{4}$ que ora reforçam ora questionam as políticas existentes, de modo a possibilitar sua entrada ou saída da agenda.

Este movimento, por sua vez, é estabelecido no interior de uma estrutura institucional composta por dois níveis: o macrossistema em que operam os líderes governamentais e o

\footnotetext{
${ }^{4}$ Policy images são as ideias que sustentam os arranjos institucionais permitindo que o entendimento acerca da política seja comunicado para os membros da comunidade, contribuindo para a disseminação das questões (Capela, 2006).
} 
subsistema, formado por comunidades de especialistas que compartilham um entendimento comum sobre uma determinada questão, o que eles chamam de monopólio. Esta divisão entre os dois grupos inspira-se na crítica à racionalidade aplicada às políticas públicas feita por Lindblom (1959), que aponta para a limitação da racionalidade dos indivíduos em lidar com a multiplicidade de questões políticas, em conformidade com o conceito de racionalidade limitada de Simon (1980), explorada anteriormente. Assim os governos delegariam a esses agentes governamentais a autoridade para processar paralelamente determinadas questões, tomando para si a ocupação com aquelas consideradas mais proeminentes (Baumgartner et al. 2007; Capela, 2006).

Embora os autores estejam preocupados em demonstrar de que forma estas diferentes arenas se relacionam, sendo o presidente uma entre tantas, eles também o consideram como o principal ator no processo de formação de agenda: "Nenhum outro ator pode focalizar a atenção de forma mais clara, ou mudar as motivações de um grande número de atores, como o presidente” (Baumgartner e Jones in Capela, 2006; p. 241).

É justamente a distinção entre o macrossistema e o subsistema, bem como a importância atribuída ao primeiro que constitui o núcleo do modelo proposto e que o tornou importante na explicação de processos de mudança política. De maneira geral, ele prevê que longos períodos de equilíbrio alcançado por determinada política podem ser, com pouca frequência, mas enormemente, interrompidos por mudanças, a depender do nível do sistema no qual ela se encontra.

"Os subsistemas de uma política pública permitem ao sistema político-decisório processar as questões de forma paralela, ou seja, fazendo mudanças a partir da experiência de implementação e de avaliação, e somente em períodos de instabilidade ocorre uma mudança serial mais profunda" (Souza, 2006b; p. 33).

O modelo foi criado pelos autores, a partir do estudo sobre a definição da agenda da política norte-americana em uma análise detida na política nuclear. Eles perceberam que a questão foi sendo gradualmente modificada de forma incremental e não incremental, momentos que foram chamados de equilíbrios e pontuações, respectivamente (Robinson, 2007; Baumgartner et al., 2007). Para eles, essa variação depende do efeito de feedback, que pode ser tanto negativo quanto positivo, responsável por manter o equilíbrio ou proporcionar as pontuações a partir da forma através da qual uma questão é definida no 
interior de um contexto institucional específico. Quando ele é negativo, o que ocorre com maior frequência, ela tende a se manter no nível do subsistema, caracterizado por uma estabilidade que resulta em equilíbrio, com pequenas mudanças incrementais. No entanto, em alguns momentos, esse equilíbrio pode ser pontuado por rápidas mudanças, efeito do feedback positivo, rompendo os limites do subsistema e chegando ao macrossistema.

Deste modo, o macrossistema é caracterizado pelas grandes mudanças na agenda. Neste processo estabelecem-se novas policy images- mistura de informações empíricas e apelos emotivos - que quando amplamente aceitas, voltam a se constituir em um monopólio no subsistema que tendem a permanecer no tempo restabelecendo o equilíbrio, que pode, não obstante, ser novamente pontuado por reformulações da mesma política, ou pela formulação de outras questões.

Estas abordagens aqui apresentadas são importantes em conjunto por duas principais razões: i) a primeira é que, seja através da distinção entre atores visíveis e invisíveis para um, ou macrossistema ou subsistema, para outro, ambas reconhecem a presença de diferentes atores na definição e implementação da agenda política, que participam destes processos a depender da posição que ocupam, ainda que este campo de atuação não seja fixo; ii) a segunda, relacionada à outra, é que eles apontam que o presidente tem papel fundamental na orientação das políticas que serão votadas e implementadas. Para os autores, é ele quem define a partir de sua própria orientação e de suas preferências as principais questões que irão compor a agenda política de seu governo, cabendo aos demais participantes barganhar para eventuais modificações nas mesmas, de modo que seus interesses sejam também atendidos.

Uma outra razão, igualmente importante, que torna o estabelecimento do agenda-setting uma questão essencial ao presente trabalho, está relacionada ao conceito de monopólio, empregado pelo modelo do Ponctuated Equilibrium. Conforme visto, é no subsistema que se encontram os atores reconhecidos por deter o conhecimento necessário à solução de determinado problema. Em consonância com o que foi abordado no item anterior, estes agentes estatais, aqui considerados pela condição de burocratas, possuem o controle sobre as informações técnicas, ou expertise, recursos poderosos na proposição e definição de escolhas políticas. O macrossistema, por outro lado, na impossibilidade de lidar com todo o conjunto das questões públicas, delegaria a esses especialistas a tarefa de processar 
paralelamente as questões que não requerem sua interferência direta, sobretudo aquelas de natureza técnica.

Segundo Weber, a fonte da superioridade da administração burocrática está amparada no papel desempenhado por seu conhecimento técnico, ou expertise. Para Rourke (1976), tal expertise é uma condição indispensável para que qualquer sistema político moderno possa funcionar, uma vez que ela é o elemento responsável por garantir que as decisões dos líderes políticos serão satisfatoriamente implementadas a partir de uma assessoria técnica competente, constituída por pessoal qualificado. Nas palavras de Weber (1966):

"A administração burocrática significa, fundamentalmente, o exercício da dominação baseado no saber. Esse é o traço que a torna especificamente racional. Consiste, de um lado, em conhecimento técnico, que por si só, é suficiente para garantir sua posição de extraordinário poder para a burocracia. Por outro lado, deve-se considerar que as organizações burocráticas, ou os detentores do poder que dela se servem, tendem a tornar-se mais poderosas ainda pelo conhecimento proveniente da prática que adquirem no serviço. Através da atividade no cargo ganham um conhecimento especial dos fatos e dispõem de uma bagagem de material documentário, exclusiva deles. Embora não exista apenas nas organizações burocráticas, o conceito de segredo profissional' é típico deles" (p. 26).

Pode-se depreender desta passagem, que a expertise é o elemento distintivo no modelo weberiano que possibilita atribuir poder às burocracias. Mas de acordo com o autor, uma vez que elas estão alijadas do jogo político e sua autoridade é circunscrita à sua influência jurisdicional, embora este poder tenha preocupado grandemente ao próprio Weber, sua dominação é puramente administrativa e restrita. Outra questão importante é que ela não deve ser entendida apenas como o conhecimento que deriva da contratação de profissionais qualificados, mas sim como resultado da contínua atenção que os burocratas devotam a um problema específico, o que fornece a eles um acúmulo de experiência na implementação de políticas, garantindo assim, uma decisiva vantagem ante os políticos que lidam dia-a-dia com uma ampla variedade de problemas no momento da tomada de decisão, o que em última instância, torna os últimos dependentes dos primeiros (Rourke, 1976).

Huber (2007) por sua vez, questiona a separação estrita entre o papel político exercido pelas burocracias com o que ele chama de neutralidade administrativa, conforme proposto por Weber. De outro modo, ele aponta que também não se pode considerar a 
administração intrinsicamente política ou puramente imparcial, isso porque embora muitas vezes as agências burocráticas implementam as leis guiadas por considerações políticas, em outras, pode parecer que o fazem de maneira tecnocrática, através de determinadas maquinações inerentes à administração pública.

Seu argumento é o de que quando determinada agência burocrática adota a linguagem de neutralidade e eficiência, ela pode estar servindo a fins políticos. Se, por um lado, seus líderes buscam implementar as decisões através de práticas de gestão interna a fím de maximizar a sua eficiência, ao mesmo tempo em que busca blindá-la das influências oriundas dos burocratas que ocupam cargos inferiores e de outras externas a ela, por outro, a centralização destas decisões pode favorecer a implementação de ações que interessam aos líderes desta agência. Isto é o que ele chama de neutralidade estratégica, que cumpre estas duas funções e serve para orientar a política pública para os fins que são desejados.

Neste emaranhado, a expertise encontra-se presente, então, em razão ora das características inerentes às burocracias ora da habilidade que seu líderes possuem em influenciar de fato, o desenvolvimento de determinada política pública. Esta influência, por sua vez, pode ocorrer através de três importantes canais: i) a habilidade dos burocratas em dar opiniões/recomendações que irão moldam as decisões dos líderes políticos, ou mesmo impor aquelas que lhes são próprias (decisão); ii) a capacidade das organizações burocráticas em realizar as tarefas definidas a partir das metas políticas (implementação); e iii) seu poder discricionário, que aparece como uma dimensão crítica relacionada ao seu poder de implementar políticas (Rourke, 1976).

Se a capacidade que as burocracias possuem para gerir seus negócios dentro de sua própria jurisdição, confere a elas um alto grau autonomia em relação às influências destoantes provindas interna e externamente, em que medida, extrapolando este pressuposto de autonomia aplicada a elas próprias - modelo weberiano - esta autonomia pode ser observada nas relações com outros atores do Executivo? Para Carpenter (2001), a autonomia burocrática ocorre quando as burocracias agem tendo em vista seus próprios interesses e prevalece se elas estabelecem, mediante esta ação, uma legitimidade política, que está ligada a diferentes elementos, como por exemplo, sua expertise, eficiência e capacidade de mobilização de grupos de interesse e da media, para que o governo adote 
sua posição. Esses últimos são essenciais para garantir sua boa reputação e consequente apoio aos seus interesses.

O estabelecimento de uma boa imagem calcadas nestas características é o que vai definir o grau de autonomia concedida a determinada burocracia, também conhecida como discricionariedade. Ela aparece como um elemento constitutivo das relações que se estabelecem entre os diferentes atores do Poder Executivo, questionando a concepção de que as burocracias desempenham um papel estritamente instrumental. O contínuo aumento do seu poder discricionário, ou seja, a relativa autonomia conferida aos burocratas para que possam agir como julgam mais conveniente e oportuno para solucionar determinado problema, tem colocado em xeque a ideia de que existe uma fronteira estabelecida entre a administração e a política, uma vez que as políticas públicas dependem, para seu bom encaminhamento, da transferência de um mínimo de discricionariedade para os burocratas (Rourke, 1976). Para Fernandes (2010), “(...) com a expansão das atividades do governo, uma parcela das decisões começou a ser tomada fora das instituições políticas e dentro dos corredores das burocracias. A administração se tornou um componente tão importante quanto as instituições políticas na estrutura do processo decisório” (pgs. 19 e 20).

Quando relacionados, os elementos expertise, informação e discricionariedade, geram uma certa ansiedade em todos os sistemas políticos diante da possibilidade que estas organizações estatais sejam autodirigidas, responsivas a si mesmas e não aos órgãos políticos que são a fonte de autoridade legítima do Estado. Diante disso, uma parte importante do corpo de teorias que englobam os estudos das burocracias passou a se preocupar, não com o fato de que as burocracias são instituições fundamentais no funcionamento dos Estados Modernos e com grande poder e autonomia para lidar com suas políticas, mas com os controles que devem ser estabelecidos para garantir que elas não ultrapassem seus limites jurisdicionais, dado o reconhecimento de seu amplo e necessário poder discricionário. A literatura especializada reconhece a necessidade de garantir a inviolabilidade da autoridade do Estado, em última instância, uma maneira de protegê-lo da influência burocrática. Uma forma de garantir as respectivas competências e atribuições é através do mecanismo de partilha de poder por parte do principal para o agente, com a delegação de um grant de autoridade ao segundo, expressa na teoria do Principal-Agente (PA). 
"Agency theory posits a dynamic process of interaction between principals and agents, which through time. In this process, bureaucrats are assumed to have distinct informational and expertise advantages over politicians. They better understand the policy and the organizational procedures that are required to implement it" (Waterman and Meier, 1998; p. 176).

A discussão que se coloca a partir dessa definição é: como o principal pode controlar possíveis comportamentos oportunistas de seus agentes quando eles possuem interesses divergentes quanto à determinada questão? Este problema será visto na sequência.

\subsection{Teoria Principal-Agente (PA): Princípios da Discricionariedade Burocrática}

A discussão sobre a importância do papel político exercido pela burocracia perpassa um debate mais amplo conformado por inúmeras correntes da literatura especializada, que foram desenvolvidas em duas vias. Segundo Fernandes (2010), na primeira, enfatizou-se a relação existente entre as agências burocráticas e os grupos de interesse, com destaque para o trabalho de Selznick (1949); na segunda, destacou-se a relação destas agências e os demais atores políticos que, não obstante, as deveriam controlar (Brewer, 2008).

Em relação à segunda, cabe destacar três abordagens: i) corrente da teoria da escolha pública aplicada à análise da burocracia, baseada no substrato de teorias de economia política e do individualismo, que buscam entender o comportamento de burocracias e burocratas, cabendo destacar aqui Willian Niskanen (1971), cuja tese central é de que os burocratas são maximizadores orçamentários e buscam maior visibilidade no interior da máquina estatal que, por sua vez, seriam alcançada através do lançamento de novos programas e políticas públicas $^{5}$; ii) análises provenientes da administração pública e sua natureza organizacional, a partir das quais, entende-se que o comportamento das burocracias é dado segundo sua estrutura organizacional, que engloba o processamento de atividades, os limites impostos externamente sobre a organização, bem como as preferências internas que estimulam o comportamento e a ação individual dos burocratas (Meier, 1979; Rourke, 1979) ; e por fim iii) a teoria do principal-agente, que ao mesmo

\footnotetext{
${ }^{5}$ A teoria da delegação tem origem nos estudos econômicos e da administração, no que tange à necessidade dos donos do capital em delegar a um corpo executivo as decisões consoantes à maximização de lucros.
} 
tempo em que aponta para o problema do controle político das burocracias, o soluciona ao defender que os políticos possuem instrumentos para controlar os outputs burocráticos, embora eles sejam excessivamente custosos e possam causar ineficiências na provisão de serviços (Weingast \& Moran, 1983; Moe, 1984). Sobre este último faz-se necessária uma análise mais detida.

Lupia (2001) aponta que a delegação é um tema central nos estudos de política, segundo o autor:

\footnotetext{
"Governments great and small use delegation to increase the range of services that they can provide. The governments of large nations, for example, delegate to defense ministries the task of maintaining national security and they delegate to finance ministries the task of managing their nation's economy. Indeed, the modern nation-state could not exist without delegation - for without delegation, lawmakers would be forced personally to implement and enforce every single law that they make. With delegation, by contrast, national governments can address a wide range of social issues simultaneously" (p. 1).
}

A delegação ocorre em razão de duas justificativas essenciais. A primeira é a impossibilidade dos Estados em alterar os ganhos que são percebidos de modo positivo ou negativo, problema que pode ser solucionado pelos burocratas; a segunda é que o fato de possuir uma burocracia concede aos Estados maior possibilidade de alcançar ganhos positivos. Seu funcionamento parte do pressuposto da divisão do trabalho e dos ganhos que são provenientes da especialização, sendo que estes últimos tendem a ser maiores quando a tarefa a ser executada é frequente, repetitiva e requer expertise específica. A partir da teoria da delegação, entende-se que existe uma concessão condicional de autoridade de um ator - órgão ou entidade - para outro, sendo que este último deverá agir em nome do primeiro. Assim, tem-se a conformação de uma relação entre um principal e um agente, entendidos como mutuamente constitutivos (Waterman e Meier, 1998; Hawkins et al., 2006; Campos, 2009; Guimarães, 2012).

Se, por um lado, a delegação torna possível aos legisladores utilizarem-se do benefício do emprego da habilidade de uma expertise na consecução de políticas que fogem ao seu escopo de competência, por outro, dessa relação podem emergir riscos, já que dela decorre automaticamente uma transferência de poder, que em outras palavras, significa a delegação de uma parcela de sua própria autoridade, por parte dos oficiais eleitos, para os 
burocratas governarem (Lupia, 2001). A principal questão que emerge deste ponto é: Como é possível, então, ao principal controlar o agente?

A literatura aponta que este controle pode ser feito de duas maneiras. A primeira, ex ante, que está relacionada à estruturação administrativa, possibilita antever o comportamento dos agentes que são contrários às preferências do principal, e consequentemente criar mecanismos para que isso não ocorra. Isso deriva do fato de que os funcionários eleitos, além de criarem as burocracias que irão atuar em seu nome, também nomeiam os burocratas-chave que irão representá-las. Não obstante, a formalização das estruturas que facilitarão o controle é feita por meio de um contrato, elemento fundamental que rege a relação entre os atores envolvidos (Guimarães, 2012).

"The first category, ex ante controls, concerns issues of agency design. What are the procedures, including reporting and consultation requirements, which an agency must follow to make policy? Who are the agency's key constituents and how will they influence decision making? What standards or criteria must an agency consider when promulgating regulations? In which executive department will the new agency be located, and how far down the organizational ladder will political appointments reach? These are all questions that legislators must answer when drafting the authorizing legislation" (Epstein and O'Halloran, 1994; p. 698).

A segunda, ex post, é caracterizada pela punição do agente após a constatação de comportamentos desviantes. Isso pode ser feito a partir do monitoramento direto sobre os agentes, aplicando sanções ou recompensas para garantir que suas preferências sejam observadas e suas decisões implementadas. Este tipo de comportamento só é possível devido à assimetria no acesso à informação do qual dispõem principais e agentes. Ao utilizar informações privilegiadas, estes últimos têm a capacidade de buscar seus próprios interesses que não necessariamente dialogam com aqueles expressos pelo Estado (Guimarães, 2012).

"The second category consists of ongoing controls, those institutions or procedures that check agency actions on a regular basis. These include instruments of congressional oversight, such as direct and indirect monitoring (...), and renewing or withholding appropriations (...). They also include judicial oversight implemented through existing administrative law (...) and presidential appointment powers ((Epstein and O'Halloran, 1994; p. 698-699) 
Grande destaque foi conferido pela literatura internacional para um melhor entendimento do emprego destes controles no sistema presidencialista norte-americano, buscando identificar, principalmente, as instâncias de decisão, os atores políticos envolvidos e como o poder é distribuído entre eles, ora com a predominância do Legislativo, ora do Executivo $^{6}$ (Neustadt, 1960; King, 1993; Moe, 1993; Bawn, 1995; Epstein andO'Halloran, 1994; Moeand Wilson, 1994; Carpenter, 2001; Howelland Lewis, 2002; Lewis, 2007; Burke, 2016).

Não obstante a importância conferida ao Legislativo neste processo, a pesquisa aqui desenvolvida preocupa-se essencialmente com as instâncias que estão à disposição do presidente para controlar os demais atores do Poder Executivo, aos quais ele delega funções, a priori, de implementação das políticas públicas. O poder exercido pelo presidente em governos presidencialistas é um dos principais objetos de análise no escopo da literatura em ciência política norte-americana (Neustadt, 1960; King, 1993; Moe, 1993; Moeand Wilson, 1994):

"Understanding presidential powers is central to understanding the American presidency and its place in politics. The nation looks to the president for direction on an ever-growing number of domestic and foreign policy issues and expects him or her to achieve results and make progress" (Burke, 2016; p.5).

Parte importante dessa literatura está voltada para o estudo específico da dinâmica intraexecutivo, em que estão contidas duas correntes de análise. A primeira, considerada institucional-legal, analisa os poderes formais, bem como a autoridade constitucional do presidente. As críticas a esta abordagem recaem sobre o fato de que poderes formais não implicam necessariamente em poder de fato ou, em outras palavras, muitas das ações praticadas pelo presidente em seu exercício de governo não estão previstas na Constituição. Além disso, com a revolução comportamentalista ocorrida na Ciência Política (Neustdat, 1960), o foco passou a ser o poder pessoal do presidente, sua

\footnotetext{
${ }^{6}$ A questão da delegação também é abordada nos gabinetes multipartidários parlamentaristas, no sentido de que os partidos políticos deverão recorrer a estratégias de controle, tal qual o presidente, a fim de aumentar sua influência sobre o comportamento de ministros. A literatura aponta que um dos principais mecanismos de controle empregado neste caso, são os nomeados políticos, que em última instância são capazes de reduzir a influência indesejada de ministros do gabinete em caso de coalizões politicamente heterogêneas (Vieira, 2013).
} 
capacidade de liderar, barganhar e assim persuadir os demais atores do Legislativo a agirem conforme seus interesses (Batista, 2014).

Em relação a esta última, embora as características pessoais do presidente não tenham deixado de integrar o rol das análises, em uma abordagem mais institucional, outros elementos foram incorporados à discussão, constituindo-se uma segunda corrente de análise. Moe (1993) aponta que enquanto análises do primeiro tipo eram reproduzidas, profundas alterações ocorriam na presidência norte-americana, tais quais sua maior institucionalização e mudanças organizacionais. Este argumento é embasado na constatação de que atualmente o poder Executivo naquele país é constituído por centenas de funcionários e redes organizacionais, de modo a tornar inviável que o presidente possa controlar a totalidade das decisões sobre programas legislativos, regulações e dotações orçamentárias, em uma negociação direta com cada parlamentar para garantir a aprovação de suas propostas.

\begin{abstract}
"We have two purposes here. The first is to bring the presidency more squarely within the terrain of positive theory by presenting it as a well-developed, nuanced, and powerful institution in its own right, rather than as a caricature whose only role in politics is to make life a little more difficult for legislators. The second is to argue that, despite positive theory's admiration of congressional power, presidents actually have substantial advantages over Congress in the institutional struggle to control government, advantages that lead to a creeping presidentialization of the system" (Moe and Wilson, 1994) (grifo nosso).
\end{abstract}

Para o autor, a questão do controle do governo, para além das disputas ExecutivoLegislativo, perpassa a discussão sobre a relação entre o presidente e a burocracia estatal. Conforme visto anteriormente, nos atuais Estados Modernos, dada a incapacidade do chefe do Executivo em tratar pessoalmente de todas as questões, sobretudo aquelas de natureza técnica, que devem ser consideradas no processo de definição e implementação de sua agenda política, ele aparelha-se com um corpo burocrático ao qual delega parte dessa tarefa. Não obstante, o problema intrínseco da delegação é garantir a capacidade do presidente em controlar as burocracias de maneira tal, que suas preferências sejam sempre respeitadas.

No escopo da teoria do principal-agente, Moe (1985) sugere o emprego de dois mecanismos que estão inter-relacionados e em grande medida seriam capazes de suprimir esse problema, a centralização e a politização. O primeiro diz respeito ao fato de que o 
presidente acaba deslocando para si uma ampla parcela das funções realizadas pelo Executivo. Utilizando como exemplo o caso norte-americano, o autor aponta que essa centralização ocorre através do Executive Office of the President, órgão de assistência direta do presidente?

O segundo mecanismo, a politização, por sua vez, teria como objetivo dotar as burocracias, e demais agências independentes, com funcionários que são da confiança do presidente, garantindo assim que suas preferências sejam sempre observadas. Quando o presidente assume seu cargo, ele acaba por herdar a estrutura institucional da presidência anterior, assim, ele busca meios para modificar a legislação, a fim de que se possa aumentar o número de posições administrativas passíveis de serem ocupadas por pessoas nomeadas por ele.

De acordo com Lewis (2007), o processo de politização influencia o desempenho da burocracia de duas formas, uma positiva e outra negativa. A primeira sustenta-se em evidências empíricas e tem validado a importância dos atores nomeados para implementação de políticas que estejam mais de acordo com a linha adotada pelo presidente. A segunda está relacionada ao fato de que nem sempre os cargos nomeados são ocupados por pessoas qualificadas para aquela determinada questão; além disso, diferentemente dos funcionários de carreira, eles tendem a ficar por prazos mais curtos e definidos devido à natureza transitória das nomeações, chegando mesmo a prejudicar o desempenho geral da agência, uma vez que ao romperem-se as equipes, programas importantes podem ser modificados ou mesmo abandonados. Outra questão importante é o efeito moral que pesa sobre a moral pública em função da distribuição de cargos e o clientelismo.

Reconhecidos os custos deste tipo de mecanismo ex ante, por que, ainda assim, os presidentes recorrem à politização e centralização burocrática? $\mathrm{O}$ autor oferece pelo

\footnotetext{
${ }^{7}$ A título de ilustração, segundo o site da Casa Branca, o EOP é composto pelas seguintes entidades: Council of Economic Advisers; Council on Environmental Quality; Executive Residence; National Security Council; Office of Administration; Office of Management and Budget; Office of National Drug Control Policy; Office of Science and Technology Policy; Office of the United States Trade Representative; Office of the Vice President; White House Office. Disponível em: https://www.whitehouse.gov/administration/eop (Acesso em 04 de junho de 2016).
} 
menos duas respostas importantes: i) os presidentes preferem optar pela negociação de alguma competência a não ter sua agenda implementada; ii) ainda que no longo prazo, esse tipo de mecanismo possa oferecer qualquer tipo de desgaste, no curto prazo, pode melhorar o desempenho da agência.

A partir do que foi exposto nesta seção foi possível verificar como a Ciência Política discute a relação entre política e burocracia a partir da observação dos mecanismos decisórios internos aos Estados. Quando se fala em APE, entretanto, entende-se tratar de ações e decisões estabelecidas entre diferentes governos nacionais ou destes com a sociedade internacional como um todo; mas por constituir-se igualmente por ações que são formuladas e implementadas pelas mesmas instituições estatais, conforme as demais políticas, são também tratadas como uma política pública (Silva et al., 2010; Pinheiro e Beshara, 2011). Deste modo, feitas as devidas ressalvas, o comportamento das burocracias em relação à formulação e implementação de política externa, deverá seguir o mesmo percurso de suas congêneres. A próxima seção buscará verificar como esta discussão é feita no campo da APE.

\section{A Análise de Política Externa: A Presença de Diferentes Atores}

As teorias que se debruçam sobre o processo de tomada de decisão especificamente em política externa, a partir da abordagem da Análise de Política Externa (APE), oferecem uma profícua perspectiva de análise. Olhando paras as estruturas domésticas, seu argumento principal é de que os Estados, ao tomarem qualquer decisão em política internacional, o fazem com fins a satisfazer interesses provenientes também de seus ambientes internos. Decorre disso, a necessidade de se examinar a real natureza deste processo pois, em última instância, é a diversidade de sistemas políticos, culturas e perfis de liderança, o que explicaria as decisões que são adotadas por diferentes Estados, ainda que estes sejam colocados frente a uma mesma pressão externa (Hudson and Vore, 1995; Kaarbo et al., 2001).

O conceito de estruturas domésticas aqui utilizado é tomado de empréstimo da obra de Risse-Kapen (1995), para quem estas são entendidas tanto como as instituições políticas quanto a estrutura social de um Estado, bem como as relações políticas que se estabelecem 
entre ambas: “(...) domestic structures encompass the organizational apparatus of political and societal institutions, their routines, the decision-making rules and procedures incorporated in law and custom, as well as the values and norms embedded in the political culture” (p. 20).

Assim, - ao observar os resultados políticos das relações externas dos Estados a partir da participação de diferentes atores circunscritos às suas esferas domésticas - a APE enuncia uma das premissas essenciais para o seu entendimento, qual seja, a de que ela constituise enquanto uma teoria de escolha política e que por isso deve levar em conta justamente o processo de tomada de decisão. Não obstante, isso se torna plausível a partir do rompimento com as teorias que sugeriam uma visão monolítica do Estado e o entendiam como um ator unitário ${ }^{8}$, afinal os analistas que se utilizam do arcabouço teórico da APE buscam identificar as unidades e as pessoas que o compõem:

"For exemple, 'the United Sates' could mean certain individuals (the president, secretary of state, secretary of defense), a set of bureaucratic agencies (the Department of State, the Department of Defense, the Central Intelligence Agency), or certain formally constituted groups with a mandate involving international affairs (the Joint Chiefs of Staff, the National Security Council, the Foreign Affairs Committee of the House of Representatives)" (Hudson and Vore, 1995; p. 210).

Outra questão de relevo para o entendimento da APE é que este tipo de análise segue em direção oposta ao pressuposto de que os atores envolvidos com a política externa agiriam de acordo com um modelo clássico de racionalidade, aquele que pressupõe que ao tomar determinada decisão os atores o fazem a fim de escolher uma alternativa considerada ótima. Seu argumento é que eles não possuem condições - principalmente técnicas e de tempo - para considerar mais do que duas ou três alternativas postas em discussão para decidir acerca de determinada questão, sobretudo porque normalmente eles são colocados diante de decisões que precisam ser processadas em condições não rotineiras - mais

\footnotetext{
${ }^{8}$ A importância atribuída à influência de atores domésticos no processo de decisão de política externa dos Estados insere-se em um debate teórico iniciado na década de 1970, ainda no campo da disciplina de Relações Internacionais, entre realistas e idealistas. Diante de profundas transformações ocorridas no plano internacional, os segundos, sensíveis também ao contexto interno, passaram a criticar a separação estrita entre a política interna e a externa, uma vez reconhecido que a multiplicidade de canais de comunicação, negociação e agendas e a diversidade de atores envolvidos nas dinâmicas internas e externas constituíam uma relação de interdependência. Diante disso tornou-se contestável a predominância da tese que entendia os Estados como atores unitários, interagindo com outros em um ambiente anárquico a fim unicamente de preservar seu poder e segurança (Keohane e Nye, 1977).
} 
adiante este ponto será tratado mais detidamente. Além disso, a abordagem incluiu nessa discussão elementos subjetivos, tais como a personalidade, as experiências individuais e a predisposição social e cultural desses tomadores de decisão.

Em relação a este último aspecto, a literatura aponta que foi o fim da Guerra Fria (19471991) que favoreceu o seu desenvolvimento, pois os modelos comportamentais passaram a oferecer um melhor entendimento para as ações adotadas por determinados atores que sofriam algum tipo de constrangimento internacional. Com o fim do embate entre Estados Unidos e a extinta União Soviética, multiplicaram-se os estudos que se voltaram para os aspectos intra-estatais, a exemplo daqueles que analisam as burocracias - em profunda relação com suas concepções acerca do papel nacional e da identidade das elites domésticas -, as características dos líderes, o estudo da interação dos agentes humanos nas relações internacionais a partir de grupos, entre outros (Hudson e Vore; 1995).

"A range of theories, approaches, notions and models were devoted to the study of foreign policy. This includes Decision-Making Approach, Rosenau's Pre-Theory, The Theory of Bureaucratic Politics with Allison's models of (i) Rational Actor, (ii) Organizational Processes and (iii) Governmental/Bureaucratic Politics, Cognitivism, The notion of Cognitive Mapping, The concept of belief System, The Approach of Domestic Political Explanation, The notion of Two-level Games, Nested Games, The Role Approach, Discourse Analysis, Social Constructivism and so on" (Sekhri, 2009; p. 423).

A observação empírica do poder exercido pelos diferentes atores, bem como a da importância de suas características pessoais em relação às decisões que são tomadas no plano internacional é fundamental para a compreensão dos recursos sociais e políticos com os quais são dotados para que possam influenciar efetivamente no direcionamento da política externa dos países. Com este intuito, Kaarbo et al. (2001) apresentam quatro grupos aos quais este poder tem sido enormemente franqueado, sendo dois deles formados a partir da agremiação da sociedade civil e os outros dois por agentes estatais.

\section{I) Sociedade Civil}

O primeiro grupo retratado pelos autores diz respeito à opinião pública, entendida como a atitude que os cidadãos de determinado Estado têm em relação à política externa, tomando como base valores simbólicos como a identidade e a cultura. Esta é uma variável 
de difícil mensuração, mas frequentemente questões que perpassam grandes temas como isolacionismo, anticomunismo, neutralidade, anti-imperialismo, etc., são usados pelo público para julgar determinada ação tomada pelo Estado, além do fato de que em uma política específica, a identidade pode ser construída por aqueles que possuem acesso aos meios de informação podendo ser usada como recurso na consecução de determinados objetivos.

O segundo é formado pelos grupos de interesse, que obtém mais ou menos sucesso em sua influência a depender das características que os constituem, tais como: i) a questão que eles defendem (direitos humanos, economia, etc.); ii) o seu grau de organização e iii) as relações que são estabelecidas entre eles e o governo. Os grupos com interesses econômicos são especialmente sensíveis às decisões em política externa porque por um lado, eles são responsáveis por produzir bens e serviços e gerar bem estar econômico e social, funções primárias dos Estados Modernos, e por outro porque eles possuem interesses próprios em assuntos externos, como a promoção de seus negócios ou a proteção do mercado nacional contra decisões adversas vindas de fora.

\section{II) Agentes Estatais}

O terceiro grupo corresponde à burocracia, entendida como a maneira pela qual um governo é organizado. Embora sua atuação seja mais facilmente observada no processo de levantamento de informações, elaboração de propostas e implementação de políticas, é correto afirmar que em alguns casos, elas exercem poder, inclusive, sobre a tomada de decisões em política externa, como se buscará demonstrar ao longo do trabalho.

Por fim, ao último pertencem os chefes do poder Executivo que têm autoridade, em última instância, para "realizar" política externa. Os autores destacam as características pessoais dos líderes como um importante elemento distintivo, apontando que quando deparados com situações ambíguas, incertas e complexas - o que frequentemente ocorre - é sua personalidade e crenças que vão conduzir, em grande medida, a decisão do Estado.

Embora estes diferentes atores tenham sido reunidos em quatro grandes grupos, em razão de sua natureza, seria incorreto argumentar que seu campo de ação seja limitado a si próprios, pelo contrário, seus respectivos poder de influência cresce em função do 
aumento de sua capacidade de se relacionar com atores dos demais grupos. Conquanto o objetivo do trabalho seja analisar o papel desempenhado pelas burocracias, é fundamental entendê-las enquanto um grupo entre os demais, que continuamente interagem com eles a fim de fazer valer seus interesses na decisão a ser tomada pelo Estado do qual faz parte.

Não se pretende aqui ignorar a importância da sociedade civil para os assuntos relacionados à política externa, uma vez que a crescente literatura sobre o tema aponta que cada vez mais esses atores têm empreendido ações além de suas fronteiras nacionais, fenômeno conhecido como relações transnacionais (Risse-Kapen, Cameron, Evangelista, Chilton; 1995). O conceito é entendido como as relações frequentes que se estabelecem entre diferentes Estados obedecendo a três preceitos: i) pelo menos um dos atores envolvidos não é um agente estatal, ii) esse ator não representa um Estado e iii) ele igualmente não representa uma organização intergovernamental. Estes grupos organizados da sociedade civil possuem seus próprios interesses em relação às políticas que são adotadas por seus países, o que os leva a buscar uma crescente influência na agenda-setting, de modo a impactar "on the global diffusion of values, norms, and ideas in such diverse issue-areas as human rights, international security, or the global environment" (Risse-Kapen 1995; p. 4).

Não obstante o reconhecimento destas questões, a pesquisa observa exclusivamente o comportamento dos agentes estatais, situados no segundo grande grupo sugerido por Kaarbo et al. (2001). Ainda que a divisão feita pelos autores não faça a distinção dos agentes estatais que estão presentes no grupo das burocracias, é importante dizer, que ele não é homogêneo quando se olha para diferentes contextos domésticos; o que existe, ao contrário, é uma grande complexidade em relação às suas funções e a maneira como elas são executadas. Não obstante, atores do Legislativo e Judiciário também participam, de alguma maneira, do processo de tomada de decisão em política externa, mas esses grupos não fazem parte da presente discussão, ainda que possam ser tangencialmente referenciados. Dito isso, ressalta-se que o foco da pesquisa recairá essencialmente sobre os atores que integram o poder Executivo, ou seja, o presidente e os burocratas que possuem um papel chave no governo a fim de verificar de que modo estes agentes estatais participam da gestão da política externa. 
Conforme foi até aqui demonstrando, essa abordagem tem ganhado cada vez mais espaço nos estudos da APE, o que por sua vez, não a distancia da tradição igualmente em expansão no campo da Ciência Política - embora pouco estudada -, que também trata da relação entre burocracia e política. Este corpo de teorias busca analisar a maneira pela qual os interesses dos quadros burocráticos, com efeito, alcançam o nível decisório, extrapolando o papel meramente administrativo que vêm sendo historicamente creditado a eles.

\subsection{Burocracia e Politica Externa}

Desde os anos 1960, diferentes estudiosos da política externa entendem que as decisões tomadas pelos Estados estão diretamente relacionadas aos processos internos que se dão principalmente no interior do Executivo (Huntington, 1961; Neustadt, 1970; Allison, 1971; Allison and Halperin, 1972). Dentre estes, grande destaque é conferido à obra "Essence of Decision. Explaining the Cuban Missile Crisis" de Graham T. Allison (1971), em que o autor propõe três modelos para o entendimento da política externa: o modelo de ator unitário (Modelo I); o modelo de processo organizacional (Modelo II) e o modelo de políticas burocráticas (Modelo III). O primeiro modelo é aquele do ator racional unitário, que agiria de forma previsível e calculada, buscando maximizar sua utilidade e sem levar em consideração disputas, barganhas ou acordos domésticos.

O modelo de processo organizacional (Modelo II), por sua vez, busca demonstrar como elementos tais como as rotinas, os procedimentos e a própria socialização organizacional impactam no processo de formulação da política externa ou mesmo podem levar à competição intra-burocrática, o que equivaleria dizer que as decisões seriam produtos de padrões regulares de comportamento baseados em processos organizacionais.

Já o modelo de política burocrática (Modelo III) centra-se no argumento de que as decisões e ações dos governos no campo internacional são resultantes da política doméstica: “(...) in contrast with Model I, this Bureaucratic Politics Model sees no unitary actor but rather many actors as players - players who focus not on a single strategic issue but on many diverse intra-national problems as well. Players choose in terms of no consistent set of strategic objectives, but rather according to various conceptions of 
national security, organizational, domestic, and personal interests. Players make governmental decisions not by a single rational choice, but by pulling and hauling" (Allison e Halperin, 1972; p. 43).

A política - jogo - é entendida como processos decisórios permeados por disputas, barganhas e alianças em que, diferentemente do modelo II, por exemplo, para além de sua posição, a habilidade de determinado grupo no interior da burocracia - jogadores -, em fazer valer seus interesses é amplamente levada em consideração. Os jogadores envolvidos movem-se por meio de canais de ação, ou seja, um conjunto regularizado de procedimentos para a produção de uma classe particular de ações. Quem joga ou não, ou com quais vantagens, dependerá da questão que estiver em curso.

As percepções e preferências de um determinado jogador partem tanto de suas características individuais, como atitudes próprias ou compartilhadas com outros membros da sociedade e do governo e atitudes relativas a ele mesmo, e de sua posição. Por outro lado, os interesses que afetam suas preferências podem ser divididos em quatro grupos: i) interesses em segurança nacional; ii) interesses organizacionais; iii) interesses domésticos e iv) interesses pessoais. Como dito anteriormente, entretanto, as decisões não são tomadas de forma aleatória, mas de acordo com regras fixas. Normalmente, questões são reconhecidas e determinadas através de um canal estabelecido a fim de produzir decisões, bem como definir os jogadores e distribuir vantagens particulares a cada um deles. A probabilidade de sucesso desses jogadores, por sua vez, dependerá ao menos de três elementos: i) a vantagens de barganha; ii) a habilidade e vontade de utilizá-las e iii) as percepções de outros jogadores sobre os dois primeiros elementos. As vantagens de barganha são estabelecidas mediante o controle que se possui sobre o processo de implementação e a posse de informações sobre os problemas que circundam determinada política, o que permite a identificação de diferentes opções para a solução dos mesmos, correspondendo, em outras palavras, ao poder e habilidade de persuadir outros jogadores, afetando seus objetivos.

Embora o trabalho de Allison (1971) tenha sido aceito pela comunidade científica, segundo Karboo (1998), ele também sofreu diversas críticas que recaíram sobre as implicações normativas do modelo; sobre seus fracassos em especificar suposições e hipóteses testáveis; em considerar os efeitos de diferentes áreas e tipos de problemas; e 
sua incapacidade de aplicação em outros lugares que não os EUA, entre outros (Krasner, 1972; Bendor and Hammond, 1992; Hollis and Smith, 1986; Freedman, 1976; Rosati, 1981).

Dentre esse conjunto de críticas, cabe destacar aquela que recai sobre o fato de que Allison parece ter diminuído a importância do papel conferido ao presidente em sua análise (Krasner, 1972; Rosati, 1981; Bendor e Hammond, 1992). Para eles, a afirmação mais importante do modelo burocrático é o pressuposto de que a formulação de políticas no interior do Executivo é realizada através da barganha mas, no entanto, eles questionam se é possível dizer que os tomadores de decisão sempre têm diferentes objetivos. Segundo esses autores, seria plausível esperar que os burocratas-chaves ao menos compartilhassem percepções e preferências com o presidente, uma vez serem indicados por este último para comporem seu quadro de governo.

Não obstante a importância dessa crítica, é importante ressaltar que a depender do país analisado, o jogo político seguirá diferentes regras que, em última instância, são responsáveis por organizar o quadro institucional e conferir particularidades àquele sistema, conforme poderá ser visto mais adiante quando as especificidades do governo brasileiro forem tomadas como estudo de caso. De qualquer maneira, o Modelo Burocrático proposto por Allison (1971) continua a ser caracterizado como uma rica fonte de análise, não apenas por fornecer pistas importantes acerca da atuação das burocracias na política externa dos Estados, mas por ser um estudo precursor neste campo continuamente em construção. Esse último aspecto indica que a questão não se encontra definida, o que significa dizer também que as discussões continuam a incrementar as análises que buscam o melhor entendimento da ação burocrática.

\subsection{Agenda-Setting em Política Externa}

Foi apresentado neste primeiro capítulo um conjunto de teorias que versam sobre questões que se encontram imbricadas na agenda de pesquisa aqui proposta, quais sejam: i) a importância do papel desempenhado pelas burocracias na tomada de decisão em política externa e ii) a influência do poder advindo de sua discricionariedade. Anteriormente foi dito que um dos principais pressupostos teóricos adotado é o de que se deve creditar às 
burocracias tão somente os poderes que ela têm. Aliado a isso, foi proposto que o rumo a ser seguido por determinada política depende justamente do grau de discricionariedade exercido pelas burocracias, pois se os interesses entre o principal e o agente foram destoantes, eles podem entrar em conflito, e este tipo de conflito foi observado por Allison (1971) em seu Modelo de Política Burocrática. Na realidade, a discricionariedade pode servir a dois interesses excludentes. Ou a discrição conferida ao agente ajuda-o a cumprir com os objetivos do principal, ou ela vai ser utilizada pelo agente para atender aos seus próprios interesses.

Uma das principais questões caras ao autor diz respeito ao tratamento de um papel em particular neste jogo político: o do presidente. As críticas levantadas em relação ao modelo apontam que ele não deu atenção adequada ao poder deste ator, já que ele é visto como sendo obrigado a barganhar com os demais atores. Para Krasner (1971) essa visão, além de ilusória, é perigosa e constrangedora. É perigosa porque ela solapa os pressupostos de política democrática retirando dos altos oficiais suas responsabilidades; e constrangedora porque oferece aos líderes uma desculpa para seus possíveis erros. Para ele, análise da burocracia é também inadequada em sua descrição de como a política é feita, uma vez que seu pressuposto axiomático é o de que a política é um jogo com as preferências dos jogadores dadas e independentes, o que ele não acredita ser verdadeiro, pois a escolha de muitos dos mais importantes jogadores e conjuntos de regras, cabem ao próprio presidente. É ele que, em última instância, seleciona as pessoas que irão encabeçar as agências burocráticas e, estes indivíduos, via de regra, compartilham seus valores - ou pelo menos deveriam -, uma vez escolhidos por suas crenças e objetivos, devendo, por isso mesmo, permanecerem como indivíduos de confiança do presidente. Este é, inclusive, um dos principais dispositivos de controle sobre a burocracia dos quais o presidente pode dispor, conforme sugerido por Waterman e Meier (1998) no arcabouço da teoria principal-agente.

Além disso, Krasner (1971) aponta que o presidente exerce importante impacto nos interesses das diferentes burocracias, pois a moral interna de cada uma delas é determinada pelo seu comportamento. Cabe a ele ainda o papel de monitorá-las, conforme também foi sugerido pela teoria do agente-principal, ou mesmo delimitar ou redefinir o escopo das atividades das organizações transferindo tarefas ou estabelecendo novas agências, caso queira. 
Portanto, é plausível admitir que a habilidade das burocracias em estabelecer políticas de forma independente é uma função de especial atenção presidencial. Isso porque ele pode envolver-se pessoalmente nas áreas que ele determina serem mais importantes; quando ele devota tempo e atenção a uma questão, ele pode compelir as burocracias a apresentálo alternativas, de modo que o contrário também pode acontecer. Além disso, ele pode mesmo recorrer ao seu próprio conhecimento e senso histórico para encontrar opções que sua burocracia falha em apresentar.

Rosati (1981) também confere grande importância ao papel do presidente, ou conforme ele sugere, ao estilo que ele possui, entendido aqui como o nível de atenção e envolvimento que ele deposita sobre as diferentes questões da agenda política. Este seria o fator mais crítico a determinar a estrutura de tomada de decisão. Nem todas as questões necessitam do envolvimento dos mesmos indivíduos e burocracias, ao contrário, as questões menores têm atenção de um reduzido número deles, enquanto o contrário também é verdadeiro. Isso o leva a concluir que existem dois principais responsáveis pela estrutura de tomada de decisão que ocorre no interior do Executivo: i) o nível de atenção e envolvimento do presidente e ii) o nível de atenção e envolvimento de indivíduos e organizações, podendo resultar em três hipóteses: Domínio Presidencial, Domínio Burocrático e Domínio Local (quando ambos os domínios são iguais).

Figura 3. Natureza do domínio de acordo com Rosati

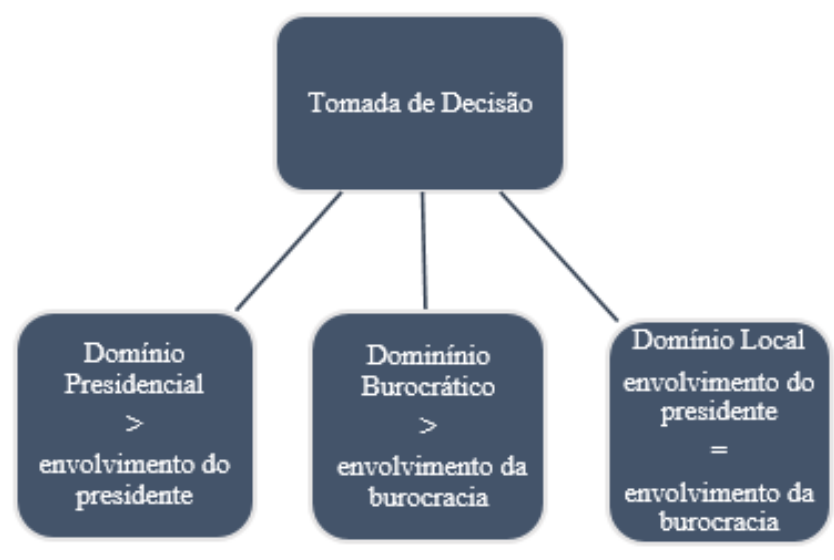

Fonte: adaptado de Rosati, 1981.

Se a política em disputa recebe atenção prioritária do presidente, diminuindo a possibilidade de manobra das agências burocráticas, então as chances destas últimas em conseguir impor suas próprias posições pode ser obstaculizada, ao passo que se sua 
participação é menor, o poder de discricionariedade das agências aumenta grandemente. Esse tipo de domínio tão somente existirá se o líder político aceitar arcar com os custos desta ação, já que ele não possui condições de lidar com todos os assuntos em pauta, e ainda que ele possua a capacidade de dialogar com suas burocracias, dado seu interesse por alguma política específica, ele não poderá fazer o mesmo em relação a outras, que considera menos prioritária naquele momento; além disso, existem os fatores de tempo e recursos despendidos para monitorar as ações de determinada agência. Se ainda assim, ele assumir estes custos, serão criados incentivos que garantam que a decisão a ser tomada respeite seus interesses, conduzindo as burocracias a criarem meios de se chegar ao objetivo fixado por ele, não deixando espaço para a existência de conflitos de interesse (Fernandes, 2013).

O que pode ocorrer de outro modo é que, a depender do grau de discricionariedade de determinada burocracia e do seu poder em relação aos seus pares que também têm interesse em determinado tema, ela possuirá meios de deliberar quase que isoladamente sobre o curso de ação a ser tomado por determinada política, constituindo assim o domínio burocrático. Agora, se ambos, presidente e burocracia, estão de acordo quanto a determinado tema, ocorrerá o que se chama de domínio local, pois ambos possuem os mesmos objetivos e partilham consenso sobre os meios para alcançá-los.

Em outras palavras, o que estas críticas ilustram é que o poder das burocracias na política externa não deve ser ignorado, apenas observado com as devidas ressalvas, levando com consideração fatores como, o contexto específico no qual elas estão inseridas, as habilidades dos atores envolvidos e o grau de atenção atribuído à política que se pretende implementar. O presidente possui formas de controle estabelecidas, em grande medida, por canais de ação legais, observando de perto o comportamento e funcionamento das burocracias que estão sob seu controle, e mesmo no caso da existência de um elevado grau de discricionariedade que algumas delas possam possuir, este é previamente instituído e, não obstante, circunscrito a parâmetros constitucionalmente limitados. Isso porque, pelo que pôde ser observado nas discussões da literatura da teoria principalagente, os Estados possuem mecanismos de controle ex ante, a partir dos quais eles desenham estruturas institucionais que sejam capazes de constranger possíveis ações deliberadas de seus agentes. Portanto, uma agenda de pesquisa inserida nessa temática, deve levar em consideração esses elementos. 
Aproximando estas discussões com o estudo de caso que será aqui apresentado, é possível perceber que para o desenvolvimento e consequente expansão da CT entre o Brasil e o Haiti, foi imprescindível a participação efetiva do presidente Lula, comprometido com uma agenda social de caráter inclusivo que atingisse os países em situação semelhante ou pior que a brasileira. A experiência doméstica havia demonstrado que em razão da agenda política adotada, havia sido possível uma diminuição dos graves problemas crônicos como a fome, a pobreza, o difícil acesso à saúde e educação, entre outros. Não obstante, os responsáveis pela gestão da expertise e recursos, foram seus ministérios, a partir da construção de uma agenda comum, que favorecesse os interesses gerais enquanto objetivos a serem alcançados conjuntamente. Foi justamente a construção desta reputação que garantiu às burocracias envolvidas não só o apoio, mas a autonomia para que disseminassem seus conhecimentos para além das fronteiras brasileiras, identificando em cada país com o qual o Brasil reforçou sua cooperação, ou passou a cooperar, seus problemas e soluções a serem adotadas, como será visto nos capítulos subsequentes.

\section{A Burocracia na Política Brasileira}

A literatura especializada, no campo da Ciência Política brasileira, aponta para a existência da predominância do poder executivo sobre as propostas políticas enviadas e aprovadas no Congresso Nacional. Este dado confirma-se a despeito das previsões que tendem a questionar a efetividade de um sistema presidencialista de coalizão, dadas as possibilidades de ocorrência de eventual paralisia decisória que seria resultante de bloqueios operados pelo legislativo como indicativo de estratégias não-cooperativas entre este último e o presidente. Dados levantados no recorte temporal que compreende os anos de 1989 e 2001 demonstraram que das 3.043 leis aprovadas no período, $86 \%$ foram iniciadas pelo presidente, que obteve taxa de sucesso de aproximadamente 90\%. Os estudiosos ressaltam ainda dois tipos de recursos postos à sua disposição que podem explicar essa aparente contradição: i) a sua forte atuação legislativa, que lhe confere poder de agenda e veto, e/ou ainda o autoriza a agir unilateralmente; e ii) o appointment power, através do qual ele pode indicar e destituir autoridades do Estado e/ou Governo (Limongi e Figueiredo, 1998; Limongi, 2006; Ignácio, 2006; Gomes, 2013). 
Entretanto, quando se fala em poder do executivo, quase sempre se privilegia uma percepção de atuação unitária, já que as propostas enviadas ao Congresso são via de regra assinadas pelo presidente, ao passo que os processos prévios de decisão que envolvem os ministros e o ministério da Casa Civil, a instância de coordenação política da presidência da República, são quase que praticamente marginalizados.

De acordo com Bresser-Pereira (2007) a burocracia pública na sociedade brasileira é entendida enquanto um grupo que conforma o setor da classe profissional constituído pelos servidores públicos, os administradores de empresas estatais, consultores da administração pública, bem como os políticos profissionais ${ }^{9}$. As camadas mais altas desse grupo, entendidas como as classes dirigentes, são, por sua vez, chamadas de alta burocracia pública ou burocracia política. Em consonância com o que foi exposto aqui na primeira parte deste capítulo, segundo o autor, o caráter político dos altos servidores foi amplamente demonstrado através de estudos realizados pelas pesquisas clássicas nos Estados Unidos, indicando que cada vez fica mais difícil diferenciar o que seria a tarefa do burocrata e do político, haja visto que nas atuais sociedades democráticas, os Estados precisam de cada vez mais eficiência na entrega das políticas públicas aos seus cidadãos. Deste modo, é errônea a percepção de que quem governa é o político enquanto o burocrata apenas administra, pois é cada vez mais evidente que o que ocorre é uma burocratização da política e uma politização da burocracia, os levando a adotar estratégias híbridas de atuação.

A literatura norte-americana oferece importantes insights sobre os estudos brasileiros de questões que envolvem o controle presidencial da burocracia pública. No entanto, é importante frisar que existem diferenças entre as duas realidades, sendo a mais importante o fato de que aquele país adota um sistema presidencialista bipartidário, diferentemente do que ocorre no Brasil, um país reconhecidamente multipartidário. Neste caso em particular, entende-se que o Poder Executivo possui maior complexidade, que envolve o contínuo aumento de ministérios a cada nova gestão bem como a formação de diferentes

\footnotetext{
${ }^{9}$ Ainda que o autor não desconsidere a literatura sobre os conflitos existentes entre políticos e burocratas no Brasil, desde os anos de 1930, ele considera os políticos profissionais também burocratas, na medida em que, quanto mais bem-sucedidos eles são, profissionalizam-se, de modo que grande parte de seus rendimentos passa a derivar do Estado. Além disso, ele destaca que os altos burocratas que não são eleitos, desempenham também papéis políticos.
} 
coalizões, muitas vezes distantes ideologicamente. Embora seja aceito que os partidos que integram a coalizão governem juntos, eles disputam as eleições separadamente, de modo que, de antemão, eles possuem suas próprias preferências e interesses eleitorais (Batista, 2014). De acordo com Vieira (2013):

\begin{abstract}
"Assim, no presidencialismo brasileiro os riscos de uma implementação burocrática pouco responsiva às preferências do Presidente da República são potencializados pelo oportunismo ministerial. Por um lado, burocratas podem fazer uso de sua expertise para tomar decisões autônomas, independentes das preferências presidenciais. Por outro lado, em posições privilegiadas e ao mesmo tempo interessados nos resultados das políticas, ministros podem exercer uma influência indesejada sobre o comportamento de servidores públicos” (p. 15).
\end{abstract}

Existem atualmente algumas pesquisas importantes sobre política e burocracia que perpassam questões como a observação da influência presidencial sobre o comportamento burocrático das agências e estudos empíricos que incidem sobre a formação e atuação da alta burocracia em mandatos presidenciais específicos. Em larga escala, estes trabalhos voltam suas análises para os procedimentos intra-executivo a fim de compreender de quais mecanismos ex ante, o presidente se utiliza para conferir controle sobre a burocracia (Loureiro e Abrucio, 1999; Ignácio, 2006; D’Araújo, 2009; Vieira, 2013; Batista, 2014; Lopez et al.; Borges e Coêlho; Lopez e Praça; Pereira et al.; Lameirão, 2015).

A exemplo do que ocorre em grande parte dos sistemas administrativos na atualidade, a burocracia é classificada em dois grupos: i) a burocracia efetiva, de natureza estável, na qual se agrupam atores selecionados por meio de concurso público; e ii) a burocracia recrutada através de nomeação discricionária, com maior poder administrativo e capacidade de influenciar a gestão das políticas, que se caracteriza por estar mais próxima da esfera político-partidária (Lopez, 2015). Faz-se necessário, portanto entender como as diferentes clivagens no interior da alta burocracia que compõem o Executivo são capazes de atuar na arena política.

D’Araújo (2009) aponta para a existência de dois grupos que congregam o topo da administração pública federal, aqueles que ocupam cargos de direção e assessoramento (DAS), níveis 5 e 6 e os cargos de Natureza Especial (NES). Estes dirigentes públicos estão logo abaixo dos ministros e secretários de Estado, ocupando um espaço gerencial perpassado por alto grau de eficiência e racionalidade. Estes postos são distribuídos 
levando em consideração importantes aspectos como o perfil daquele que se pretende nomear, as práticas institucionais de gestão pública, o tipo de comando exercido pelos ministros e secretários.

Desde que foram criados em 1967, ainda no período do regime militar, até a redemocratização, os cargos DAS passaram por diferentes alterações no que diz respeito aos seus formatos e também nas regras para o seu preenchimento. A partir de 1976 o grupo DAS passou a ser distribuído em seis níveis hierárquicos, com regras diferentes para seu provimento: i) níveis de 3 a 6 e dirigentes de autarquia, nomeados por ato do presidente da República; ii) níveis de 1 a 2, nomeados por ato do ministro de Estado ou dirigente de órgão integrante da Presidência da República ou de autarquia federal.

Não obstante, em 2003, início do primeiro mandato de Luiz Inácio Lula da Silva, este padrão sofreu algumas alterações, de modo que a Casa Civil passou a centralizar todas as decisões para preenchimento dos cargos de DAS estabelecendo, além disso, uma nomenclatura padrão dos diferentes níveis hierárquicos dos cargos em duas categorias: DAS-101, que se refere aos cargos de direção superior e DAS-102, no qual estão os cargos de assessoramento superior. Em junho do mesmo ano, foi publicada uma portaria que alterou este quadro, subdelegando aos ministros de Estado o poder de nomear cargos DAS nos níveis de 1 a 4, cabendo à Presidência, por meio da Casa Civil, a nomeação dos níveis de 5 a 6, permanecendo assim até o segundo mandato. Ainda sob o governo Lula, em 2005, foi editado o decreto $\mathrm{n}^{\circ} 5.487$ que estabelece que $75 \%$ dos cargos de DAS níveis 1 a 3, e 50\% de nível 4 deveriam ser ocupados apenas por servidores civis, muito embora este regulamento na prática não seja confirmado (D’Araújo, 2009; Vieira, 2013).

Os cargos de Natureza Especial (NES) também são reconhecidos como postos de confiança de livre nomeação, e juntamente com os cargos de DAS 5 e 6 formam o núcleo central da administração pública federal. Através da Lei nº 8.028, de abril de 1990, editada no governo Collor de Mello, foram criados 24 postos de NES, sem explicar, entretanto, sua forma de provimento.

A distribuição e ocupação destes cargos perpassam por diferentes discussões nos estudos sobre a burocracia no Brasil, podendo-se destacar: i) a relação que se estabelece entre a nomeação e o patrimonialismo, que por sua vez teria tirado a legitimidade da esfera 
política; ii) avaliações sobre a eficiência dos nomeados; iii) o fato de o espaço destinado ao livre provimento ser muito amplo e indevidamente politizado, de modo a influir negativamente na capacidade de gestão da agência e implementação de boas políticas; iv) a alta rotatividade dos cargos enquanto elemento comprometedor do ciclo de execução das políticas; e por fim, v) a capacidade de controle dos ministérios como um todo, por parte do presidente (Lopez, 2015). Ainda que seja reconhecida a importância de cada uma destas questões, a última delas possui importância relevante para o trabalho aqui realizado.

A literatura indica dois mecanismos para lidar com os problemas de controle ministerial: a nomeação presidencial de secretários-Executivos para monitorarem a coalizão e a centralização das decisões pelo presidente. Quanto ao primeiro, de acordo com Pereira et al. (2015), no nível hierárquico, os secretários-Executivos estão apenas abaixo do ministro, de modo que o presidente utiliza-se deste recurso na tentativa de minimizar a assimetria informacional dando a eles não apenas a prerrogativa de monitorar a ação dos agentes no interior dos ministérios, mas também de influir em decisões tomadas pelo ministro para que as decisões ministeriais não sejam contrárias às suas preferências.

Ainda conforme apontado pelos autores, não obstante a prerrogativa constitucional que garante ao presidente nomear um secretário-Executivo, ele pode ainda conferir autonomia para que o próprio ministro o faça, aceitando, consequentemente, os custos desta escolha. Eles sugerem que o presidente tenta equilibrar ao máximo a necessidade de contar com o apoio político-partidário, de modo a conferir certa liberdade às agremiações, exercendo o controle sobre as escolhas desses mesmos partidos, a depender i) do tamanho da bancada dos partidos da coalizão; ii) da distância ideológica entre o partido do presidente e do que controla o ministério e iii) da relevância do ministério para o governo. Analisando os governos de FHC e Lula (de 1995 a 2010), eles chegam à conclusão de que os presidentes, de forma geral, nomeiam o SE quando as diferenças entre o partido do presidente e os da coalizão são substantivas, ao passo que a ideologia, o tamanho da bancada e relevância da pasta influem de forma positiva.

Em relação ao segundo mecanismo, que diz respeito à adoção de uma postura mais centralizadora por parte do presidente, Batista (2014) apresentou um detalhado trabalho de análise também dos dois mandatos de FHC e de Lula, a fim de analisar a influência 
dos ministérios em iniciativas legislativas das políticas públicas e na distribuição da execução orçamentária, chegando à conclusão de que eles são atores relevantes mais no primeiro caso que no segundo, o que demonstra que "ministros e partidos por trás desses ministérios influenciam as decisões do Executivo, de forma que controlar um ministério é um instrumento para acesso privilegiado sobre decisões importantes para o partido, e não simplesmente mais um cargo" (p. 183).

Esses resultados foram obtidos através da análise de um banco de dados composto pelo envio de projetos de lei (PL), medidas provisórias (MP), projetos de emenda constitucional (PEC) e projetos de lei de conversão (PLP), todos de competência do Executivo, ao Congresso. Seu universo foi constituído de 1.715 iniciativas legislativas, sendo 823 PLs, 54 PECs, 784 MPs e 54 PLs, nos quais a identificação do proponente foi feita através da leitura das exposições de motivos, documento que acompanha os instrumentos normativos.

No que diz respeito ao recorte temporal que interessa particularmente à pesquisa aqui empreendida, segundo a autora, durante o governo Lula, a Casa Civil fortaleceu o seu papel em monitorar tanto os aspectos jurídicos quanto os de méritos dos atos normativos do Executivo, possuindo assim competência para avaliar as matérias em tramitação no Congresso Nacional; o órgão incorporou um papel de coordenação e formação de acordos entre os ministérios para que estes sempre observassem as preferências do presidente. Além disso, ela conclui que variáveis como a distância de preferências entre o partido do presidente e o do ministério, a força legislativa do partido do ministro e o número de dias do partido na coalizão, influenciam no grau de centralização da produção legislativa observada no maior ou menor grau de discricionariedade conferida pelo presidente a qualquer ministério que se pretende analisar.

Estes estudos constituem-se em peças fundamentais para a compreensão do processo de tomada de decisão no interior do Executivo, bem como as relações de poder que se estabelecem entre o presidente e os ministros. Entretanto, pouco tem sido escrito em relação a este contexto no tocante à definição e implementação da política externa brasileira. Dois pontos podem explicar este quadro i) o histórico grau de insulamento do MRE; ii) a diferenciação entre política externa e demais políticas públicas; iii) o ainda 
recente processo de horizontalização da PEB com a presença mais ativa dos demais ministérios para sua consecução, conforme será observado à frente.

\section{Burocracia Brasileira e Política Externa}

\subsection{O insulamento burocrático do Itamaraty}

Se até a década de 1990 existia a percepção de que a decisão e implementação da política externa brasileira cabiam unicamente ao MRE, após este período, entretanto, ela foi sendo paulatinamente alterada. Durante a história brasileira, o Itamaraty constituiu-se enquanto o principal ator em política externa, muito em razão do que a literatura chama de seu insulamento burocrático, entendido como a redução do espaço nos quais diferentes interesses extra-institucionais poderiam acomodar-se e representar alguma importância, mantendo seu monopólio e autonomia nos assuntos pertinentes à área. Dois fatores podem explicar esta distinção: i) a fortemente estruturada carreira diplomática brasileira; e ii) seu alto grau de profissionalização (Cason e Power, 2009, Pimenta de Faria, 2012a).

O que se pode notar a partir dos anos 1990, entretanto, é uma busca para a ampliação do escopo das capacidades de ação dos seus pares governamentais e da sociedade civil (Pimenta de Faria, 2012a). Cason e Power (2009) indicam três ordens de fatores que podem explicar esta substantiva alteração: i) mudanças ocorridas no sistema internacional; ii) alternância de líderes políticos e iii) o interesse dos grupos domésticos ou das organizações estatais.

No plano internacional, assistia-se ao fim da Guerra Fria, que entre outras consequências, acarretou a fragilização da hegemonia até então norte-americana, levando o país a consolidar uma agenda mais positiva de negociação no campo da diplomacia, aliada ao recente processo de redemocratização interna, que atuou como um agente de pressão para uma política externa com maior participação social.

O governo Collor foi marcado por um período de grande tensão na política brasileira, sobretudo aquela de caráter político-econômico, com escândalos que levaram ao impeachment do então presidente. Em relação à política externa, ocorreu um 
desentendimento entre os objetivos expressos por ele, de ordem mais liberal - orientados pela relação Brasil-EUA - e os do Itamaraty, aliado a outros grupos de interesse, com caráter mais globalista. É possível perceber neste contexto uma maior abertura para a participação extragovernamental na PEB, evidenciando sua maior politização, em relação ao seu novo componente distributivo, favorável à criação de novas coalizões domésticas (Lima, 2000; Pimenta de Faria, 2007; Saraiva, 2007; Lopes, 2011).

Com o impedimento de Collor, tomou posse seu vice-presidente Itamar Franco. Seu ministro das Relações Exteriores, ou o Chanceler, era o então senador Fernando Henrique Cardoso, responsável por realizar, em 1993, um ciclo de seminários sobre os rumos da PEB chamado "Reflexões sobre a Política Externa Brasileira" e que distinguia-se por ter entre seus participantes diferentes membros da sociedade, como acadêmicos, empresários, sindicalistas e diplomatas, o que parecia significar a abertura definitiva dos assuntos da política externa brasileira. Um dos elementos mais importantes resultante deste encontro foi a formulação da "necessidade de uma diplomacia pública", pois o Itamaraty reconhecia, como defensor do regime democrático, que fossem feitas novas propostas capazes de criar maior capilaridade social da PEB. Disso resultou o plano de criação de um mecanismo institucionalizado de diálogo entre os stakeholders da PEB. O que se buscava com isso era a criação de uma diplomacia que fosse também uma "política nacional”, com coordenação interna entre as burocracias nos três níveis federativos, o Congresso e algumas personalidades da sociedade, abrangendo as organizações políticas, empresariais, sindicais, culturais e acadêmicas (Lopes, 2011).

Não obstante, foi durante o governo de FHC que a PEB tomou contornos ainda mais plurais. Souza (2001) criou um survey sobre a Percepção do Insulamento do MRE, junto à "comunidade de política externa", constituída por 149 membros, entre os quais incluíam-se o Executivo (o presidente, seus ministérios-chaves, o corpo diplomático, as forças armadas e o Banco Central); o Congresso Nacional (deputados e senadores envolvidos em relações internacionais e políticas de defesa); empresários; representantes de ONGs, jornalistas e acadêmicos da área. Ele pode auferir que na percepção destes atores, existiam diferentes graus de percepção em relação ao insulamento do Itamaraty, sendo que os Ministérios eram os que mais o percebia. Cason e Power (2009), apontam três implicações desta pesquisa: i) independente do grau de autonomia exercido pelo MRE, diferentes elites têm capacidade de participar da PEB; ii) a pluralização de atores 
no processo de decisão em política externa a partir de 1990 deve ser entendido em termos relativos, mais que em termos absolutos e por fim, iii) que existia uma percepção geral de quase-monopólio do Itamaraty sobre a PEB.

Ainda ao se tratar a questão do insulamento do MRE a partir da perspectiva presidencial, ou seja, levando em consideração o papel exercido pelos presidentes a partir da década de 1990, fica claro que estes passaram a exercer um papel muito importante para a PEB desde então. Outro importante trabalho que aponta para essa tendência foi realizado por Fernandes (2010). Utilizando como estudo de caso a política econômica e a constituição em 1995, sob o governo FHC, da Câmara de Comércio Exterior (Camex), ele aponta que caberia a está última a função de formular políticas e coordenar a ação pública em comércio exterior, apresentando-se como um foro deliberativo de discussão e consolidação das posições dos diferentes ministérios envolvidos com a temática.

Além disso, FHC mostrou-se pró-ativo, não apenas em relação à criação da Camex, mas também em sua participação efetiva em política externa, inaugurando no Brasil o que se convencionou chamar de diplomacia presidencial, totalizando 92 viagens em seus oito anos de governo. Seu engajamento era maior com os países desenvolvidos da Europa e com os Estados Unidos, entretanto, ele abriu precedentes para o fortalecimento de relações regionais com a América do Sul através do Mercosul, ao mesmo tempo em que se aproximou de outras potências consideradas médias e de grande porte, destacando-se Índia, China, Rússia e África do Sul, sem perder de vista, entretanto, uma implícita motivação comercial (Cason e Power, 2009; Saraiva, 2007; Vizentini, 2012).

Se, por um lado, este maior interesse do presidente na PEB significou a possibilidade de promover mudanças na maneira como ela seria conduzida, por outro fez emergir uma discussão a respeito da politização da mesma, mais fortemente apontada e criticada no governo de seu sucessor. Para Lopes (2011), coloca-se neste contexto uma questão ontológica pertencente ao campo das definições primárias: a política externa é uma política de Estado ou uma política de governo? Para Celso Amorim, ministro das Relações Exteriores que ocupou a cadeira durante os dois mandatos de Lula, as premissas da PEB deveriam levar em conta as interpretações e contingências estabelecidas pelo governo em exercício, de modo a ser uma política pública que, obrigatoriamente, como suas congêneres, deve espelhar as atitudes e percepções do governo. 


\subsection{Política Externa como Política Pública}

Grande parte das análises sobre política externa tende a considerá-la enquanto um domínio distinto das demais políticas públicas, configurando-a a partir de elementos excepcionais, distantes das discussões sobre a política doméstica. É atribuída a ela preocupação com problemas de interesse nacional, que nada se assemelham àqueles das quais as demais políticas preocupam-se. Entretanto, o que se observa na atualidade é que as duas cada vez mais estão em interação, uma vez que práticas inseridas em diferentes campos, como segurança pública, saúde, agricultura entre outras, passaram a ser internacionalizadas pelo Estado, mobilizando diferentes atores em sua consecução.

Adotar a concepção de que a política externa é também uma política pública possibilita com que seja desenvolvida uma abordagem dos processos decisórios nos Estados democráticos, que agora são mais plurais e complexos, possibilitando o emprego da mesma metodologia de análise que remete às políticas públicas domésticas (Sanchez et al., 2006). A partir da análise constitucional das competências em política externa no Brasil, os autores observam que há grande preponderância do papel do poder executivo, como ocorre com as outras políticas (seção 3 deste capítulo). Aplicando a metodologia às políticas públicas, os autores sistematizaram os temas pertinentes à política externa: i) celebrar tratados; ii) declarar guerra e celebrar a paz; iii) e manter relações com outros Estados e participar de organizações internacionais. Olhando para cada um deles, eles observaram uma distribuição entre os poderes Executivo, Legislativo e Judiciário. Foi observado que a Constituição de 1988 garante ao poder Executivo, quando comparado aos demais poderes, um papel concentrado nas fases de formulação e decisão da política externa, sendo mais evidente nos temas de declaração de guerra e celebração da paz. De forma geral, o que os autores demonstram é que este poder possui papel central na formulação e decisão em política externa, o poder legislativo atua no processo de (co)decisão a posteriori e o poder Judiciário, em eventual participação ad hoc.

No interior do Poder Executivo, sempre houve a percepção de que o ministério envolvido diretamente com a política externa era apenas o MRE; entretanto, conforme observado, a entrada de áreas específicas na agenda internacional do país, fomentou-se a participação 
de outros ministérios, tanto no processo de formulação quanto no de implementação da agenda política governamental. "A ideia de insulamento burocrático como característica patente do Itamaraty, de que o ministério teria o condão de definir os rumos da política externa de forma soberana e autônoma, isolado do restante da sociedade e da burocracia, ainda que mantenha sua força explicativa e teórica, não mais condiz com o momento atual pelo qual passa o país e o próprio ministério em questão" (Albuquerque, 2013; p. 71).

\subsection{A Horizontalização das Competências no contexto da Cooperação Sul-Sul}

As análises iniciais sobre a Cooperação Sul-Sul (CSS) no Brasil estiveram, em sua grande maioria, circunscritas às tentativas de lidar com a rápida emergência do fenômeno a partir do processo de reordenamento das relações do países do Sul com seus pares, que havia, por sua vez, tornado possível a reconfiguração da inserção internacional dos mesmos nos planos econômico e político. Posteriormente elas passaram a abranger diferentes abordagens que a colocavam enquanto uma importante prática para o problema do desenvolvimento no mundo (Lima, 2005; Saraiva 2007; Hirst, 2012; Milani, 2014).

No entanto, é fundamental salientar que a CSS não pode ser compreendida como um conjunto homogêneo de práticas guiadas por um protocolo fixo de execução, pelo contrário, sua arquitetura incorpora diferentes arranjos institucionais, princípios, objetivos e consequentemente, distintas práticas. Estas dificuldades não têm impedido, entretanto, que alguns esforços, como o que resultou no primeiro levantamento oficial sobre a Cooperação Brasileira para o Desenvolvimento Internacional (COBRADI), publicado em 2010 pelo IPEA em conjunto com a Agência Brasileira de Cooperação $(\mathrm{ABC})^{10}$, colaborem para clarear este cenário.

É possível dizer que entre as sete diferentes modalidades de investimentos dos recursos brasileiros para a cooperação internacional, a cooperação técnica tem obtido grande

\footnotetext{
${ }^{10}$ A responsabilidade formal de coordenar, negociar e supervisionar tanto os projetos de cooperação técnica recebidos do exterior, quanto os quais o Brasil é provedor fica a cargo da ABC, sendo as iniciativas de CTPD reguladas pelos Acordos Básicos de Cooperação, que por sua vez, estão sujeitos a aprovação legislativa e por Ajustes Complementares e Documentos de Projetos.
} 
destaque entre os analistas. Duas razões podem explicar essa preferência: i) a prática não só possibilita, como necessita da participação de outros atores, que não apenas o presidente e o MRE, para a sua consecução e relacionado a isto, ii) ela tem atuado como uma importante manifestação do processo de internacionalização das políticas públicas brasileiras para demais países igualmente em desenvolvimento, evidenciando assim, o crescente poder de agência exercido pelos ministérios na política externa brasileira contemporânea (ABC e IPEA, 2010; Pinheiro e Beshara, 2011; Pimenta de Faria, 2012a, 2012b; Albuquerque, 2013; Leite et. al, 2013; Milhorance, 2013; Milani 2014; Milani e Lopes, 2014).

Por isso, nos últimos anos, os estudos sobre a política externa brasileira, conforme visto, vêm questionando o caráter insular do Itamaraty no tocante a decisão e implementação de políticas. Diferentes estudos apontam para a atuação de uma pluralidade de atores e agendas, dividindo-os entre os governamentais (Ministérios, Agências Federais e Entidades Subnacionais) e os não-governamentais (ONGs e empresas privadas). No que se refere aos entes estatais, essa mudança conduz à cada vez mais expressiva noção de authoritativeness, em que órgãos públicos e entidades subnacionais buscam construir a agenda de cooperação para o desenvolvimento, a partir da autorização do principal ator, ou seja, a Presidência da República (Cason e Power, 2009; Silva et al., 2010; Lopes, 2011; Pinheiro e Beshara, 2011; Pimenta de Faria, 2012a; Milani, 2014).

Segundo Pinheiro e Beshara (2011):

"Sublinhamos que a presente pluralização de atores - causa e efeito da diversificação temática da política externa - também deve ser pensada como um elemento central na compreensão da política externa brasileira contemporânea. Duas categorias ou expressões complementares ajudam a entender esse novo quadro: dispersão disciplinada, como sugere Beshara (2008), e horizontalização controlada, como sugere Pinheiro (2009). Ambas, como veremos, resumem os dois movimentos por que passa atualmente a formulação e a implementação da política externa brasileira em suas diferentes modalidades diplomáticas: participação crescente e diversificada de atores na formulação e implementação da política externa, concedendo maior respaldo interno, legitimidade externa e eficiência às políticas e às decisões; e busca incessante de coordenação e controle sobre essa nova configuração da política externa brasileira por parte do Itamaraty" (p. 154). 
É importante trazer para a discussão esta questão do MRE, demais ministérios e o presidente, que está perpassada por questões conceituais entre cooperação e coordenação. Para Souza (2006a), a cooperação existe quando há autonomia formal entre aqueles que participam de determinada ação, que ocorre, por exemplo, nas relações que são estabelecidas entre os governos subnacionais, autônomos enquanto entes federados, e a sociedade civil. A coordenação, entretanto, acontece entre aqueles que compartilham uma mesma fonte de autoridade capaz de centralizar decisões, que as estrutura hierarquicamente de cima pra baixo, como é observado entre o MRE e os demais atores e agências do governo federal.

Dito isto, em consonância com o que vem sendo apresentado, é possível afirmar que o poder sobre a PEB, embora esteja quase que totalmente concentrada na figura do presidente, tem sido delegada aos demais ministérios para tornar possível a sua consecução. Para Pimenta de Faria (2012a), "ele delega, dada a impossibilidade prática da tarefa, autoridade aos ministros para a resolução de três problemas cruciais de coordenação das funções do Executivo, quais sejam: execução das políticas, integração dos diferentes departamentos administrativos do governo e também, muitas vezes, busca de apoio político no Congresso Nacional” (p. 321).

Ainda para o autor, o grau de autonomia delegada a esses ministros, entretanto, vai depender de sua credibilidade, dos recursos técnicos e materiais disponíveis no ministério, sua habilidade e, sobretudo, da relevância que a política tem para o próprio presidente. Em um levantamento dos 23 Ministérios do presidente Lula feito em junho de 2009, o autor aponta que à exceção do MRE e do Ministério da Integração Nacional, todos os outros possuíam Secretarias de Relações Internacionais, Diretorias ou Assessorias de Assuntos Internacionais, ou órgãos que exercem este tipo de tarefa. Dois importantes trabalhos na área são de extrema importância para essa discussão e oferecem a base metodológica para a observação empírica que será apresentada nos dois últimos capítulos. 
No primeiro, França e Badin (2010), a fim de verificar o alcance das competências dos órgãos da administração direta do poder Executivo ${ }^{11}$ na política externa, realizaram uma pesquisa que apontou para o que eles chamaram de processo de "horizontalização de competências". No âmbito da administração direta estão os Órgãos de Assistência Direta e Imediata (OADI), compostos pela Secretaria Executiva, pelo gabinete do ministro e pela consultoria jurídica e os Órgãos Específicos Singulares (OES) compostos pelas Secretarias de Estado. A fonte de informação para a pesquisa foi a regulamentação infraconstitucional, formada pelos decretos que aprovam a estrutura regimental dos órgãos do poder executivo federal e as portarias ou anexos dos próprios decretos com os regimentos internos desses órgãos, consultada em julho de 2008.

Eles apontam que a regulação que determina as competências dos diferentes órgãos da União cada vez mais dotam órgãos do Poder Executivo Federal, desde aqueles que compõem a Presidência da República até os Ministérios, de competência para atuar em política externa. Foram encontrados três tipos de inserção dos órgãos que possuem canais de atuação internacional, que em alguma medida encontra-se relacionada ao grau de discricionariedade conferida a cada um deles: i) 26,5\% dos órgãos têm capacidade de processar informações e assessorar tanto jurídica quanto politicamente outros órgãos no interior do mesmo ministério; ii) 16,2\% dos órgãos federais têm capacidade de firmar acordos no campo da política de cooperação técnica internacional e iii) 13,7\% dos órgãos estão legalmente capacitados a negociar e defender a posição do país junto às instâncias e organizações internacionais.

Eles ainda chegaram à conclusão que dos $56,4 \%$ dos órgãos presentes no grupo dos OADI, 25, 6\% deles compõem as estruturas que assessoram diretamente os ministros (OADI) e 30,8\% atuam em assuntos relacionados às próprias áreas das quais esses ministérios se ocupam. Dentre os 22 ministérios analisados, a proporção de órgãos com competências para decidir em organismos internacionais perfazem $60 \%$, o que indica que a legislação brasileira confere alto grau de autonomia tanto para a participação quanto para a definição da PEB, sendo isto passível de duas explicações. A primeira tem relação

\footnotetext{
${ }^{11}$ Foram incluídos, além do presidente e dos ministérios, órgãos que não dispõem de personalidade jurídica própria, mas que se expressaram por meio da figura jurídica da União.
} 
com o aumento da expertise exigida nas negociações internacionais e a segunda espelha mais profundamente o tipo de contribuição que se espera dos ministérios na PEB.

Os principais ministérios que englobam este grupo e que possuem, pelo menos $50 \%$ de sua estrutura vinculada a temas internacionais são: Agricultura, Pesca e Abastecimento (MAPA); Ciência e Tecnologia (MCT); Comunicação; Defesa; Desenvolvimento, Indústria e Comércio (MDIC); Educação (MEC); Esportes; Fazenda (MFaz); Meio Ambiente (MMA); Minas e Energia (MME); Previdência Social (MPS); Saúde; Trabalho (MTE); Ministério do Desenvolvimento Agrário (MDA); Ministério da Integração Nacional; Transporte e Turismo.

Entretanto, eles se colocam a seguinte questão: Se o papel creditado a estes ministérios está relacionado muito mais aos seus órgãos técnicos, como é feita a articulação propriamente política e estratégica entre eles e o MRE e o presidente da República? Ao que eles respondem:

"Dentre as possibilidades aventadas para as posições emitidas por tais órgãos na formulação da política externa e nas relações internacionais tem-se: (i) suas posições são articuladas em diferentes fóruns ou órgãos colegiados, com participação de outros ministérios, no âmbito da estrutura do poder executivo - tais como conselhos e câmaras ou (ii) suas posições são formuladas em conjunto com outros ministérios, como o Ministério das Relações Exteriores” (p. 17).

Eles consideram os conselhos e câmaras como os motores da autonomia dos órgãos presentes nos Ministérios. De acordo com o art. 1.IV do Decreto n. 5.772/2006, o Gabinete de Segurança Institucional exerce as atividades de Secretaria Executiva da Câmara de Relações Exteriores e Defesa Nacional, do Conselho de Governo. É ela a responsável pela formulação de políticas públicas e demais matérias circunscritas à política externa no Brasil e à defesa nacional, e pela articulação de temas relevantes entre os ministérios. Sua composição é feita pelos ministros de Estado: do Gabinete de Segurança Institucional da Presidência da República; da Casa Civil da Presidência da República; da Justiça; da Defesa; das Relações Exteriores; do Meio Ambiente; da Ciência e Tecnologia; do Planejamento, Orçamento e Gestão; do Meio Ambiente; da Ciência e Tecnologia; da Fazenda e da Secretaria de Assuntos Estratégicos. 
As competências das Secretarias de Relações Internacionais são amparadas pelo Decreto n. 6.207/2005, art. 8.I que dizer ser sua responsabilidade a coordenação e a supervisão da participação do Conselho de Desenvolvimento Econômico e Social junto a entidades e diferentes organismos nacionais e internacionais. Segundo França e Badin (2010): “Esse conselho é composto basicamente por representantes da sociedade civil e do governo, com a finalidade de assessorar o presidente da República em assuntos estratégicos do país”(p.17).

Em síntese, uma das principais conclusões a que os autores chegam é que as secretarias e assessorias em relações internacionais dos ministérios, depois do MRE são o lócus mais evidente da PEB. Não obstante, o papel que elas ocupam no processo de formulação, definição e implementação de política externa, vai depender do grau de autonomia conferida a seu respectivo Ministério, o que possibilitaria inclusive, que no interior deste, - a depender da maneira como está posta a organização em torno do ministro - além de executarem seus papéis de assessoras, elas teriam ainda competências para concretizar ações no campo da cooperação internacional, propor a realização de acordos ou mesmo participar ativamente em eventos internacionais.

O segundo trabalho foi realizado por Silva et al. (2010). Utilizando metodologia semelhante à França e Badin (2010), também para o ano de 2008, as autoras chegaram à conclusão de que, quando se observa os decretos específicos que estabelecem a estrutura regimental dos ministérios, secretarias e conselhos que compõem o Executivo, $35 \%$ da estrutura da Presidência da República, $45 \%$ da estrutura dos ministérios e $30 \%$ da dos conselhos possuem competências para atuar em política externa, o que confirma a existência de um processo de horizontalização ou como elas chamam de “descentralização horizontal” da tomada de decisão.

Não obstante, como caráter inovador, as autoras demonstram que a abrangência não se restringe à fase de implementação da política, mas está presente também na formulação. Utilizando-se de quadros demonstrativos que dizem respeito às fases pelas quais a política pública percorre, segundo a literatura, elas identificam nos textos dos decretos que regem as atribuições dos Ministérios, as competências que podem ser atribuídas também à fase de formulação, chegando à conclusão de que estas etapas encontram-se sobrepostas, tanto no que diz respeito à sua natureza, quanto aos atores aptos a efetivá-las 
A questão que se coloca em tela é a de como estes arranjos institucionais entre presidente e ministérios podem ser observadas no caso do ministério da saúde (MS) e mais propriamente com a cooperação técnica exercida por este último no Haiti, exercício a ser realizado a partir do capítulo 3 da presente dissertação. Antes disso, porém, é importante não apenas traçarmos o histórico e o panorama da CTPD no recorte histórico aqui privilegiado, o que será feito no capítulo seguinte.

\section{Considerações Finais}

O que as recentes pesquisas em política externa brasileira demonstram, é que com cada vez mais frequência os ministérios têm sido dotados de competência para lidar com as questões internacionais, sobretudo em função da necessidade do emprego de suas respectivas expertises na consecução das atuais políticas de cooperação com o eixo sul, em que a vertente técnica alcançou grande destaque. Neste contexto em particular, o poder político das burocracias ganha ainda mais força, tanto na fase de implementação, quanto na de formulação de suas políticas setoriais para além da fronteira nacional.

Por tratar-se de um fenômeno relativamente recente, é possível afirmar que existem muito mais perguntas do que respostas propriamente ditas, dado que o processo todo em si, ainda requer maiores observações. Entretanto, o que os estudos têm demonstrado, é que a relação entre o presidente e suas burocracias, no que tange à tomada de decisões da política de cooperação técnica, necessitam com urgência de uma maior atenção dos pesquisadores (França e Badin, 2010; Silva et al., 2010; Cepik e Sousa, 2011; Pimenta de Faria, 2012).

O capítulo buscou argumentar que, dada a incipiência de estudos a esse respeito na seara da APE, uma possível forma de analisar as relações entre esses dois principais atores presentes no processo é através dos estudos da delegação política. Assim, podem ser reconhecidos os mecanismos de controle utilizados para garantir que a agenda presidencial seja respeitada, limitando a discricionariedade dos ministérios, a exemplo do que ocorre também com as demais políticas públicas nacionais. 
O capítulo seguinte, por sua vez, buscará demonstrar através do estudo da CT empreendida pelo país no Haiti, no período correspondente aos dois mandatos de Lula, como o aparato institucional brasileiro confere ao presidente papel de destaque no processo de formação do agenda-setting da política de cooperação, trazendo para a discussão os meios jurídico-políticos dos quais ele dispõe para garantir a máxima sincronia de interesses possível com os ministérios que estão sob sua coordenação, buscando, não obstante, contínuo diálogo com o corpo teórico aqui apresentado. 


\section{CAPÍTULO 2. COOPERAÇÃO ENTRE PAÍSES EM DESENVOLVIMENTO: A PERSPECTIVA BRASILEIRA}

O fato de a Cooperação Sul-Sul (CSS) ter tornado-se objeto da atenção de diversos pesquisadores nos últimos anos demonstra não só sua relevância enquanto importante instrumento da política externa brasileira mas também aponta para diversos desafios colocados pelos analistas. Há consenso entre estes investigadores que sua análise diz respeito às substanciais alterações ocorridas no cenário internacional nas últimas décadas, que tornaram possível um reordenamento das relações dos países do Sul com seus pares e consequentemente sua inserção mundial, tanto no plano econômico quanto político (Lima, 2005; Saraiva, 2007; Hirst, 2012).

Lima (2005) aponta que entre 1960 e 1970, países como Índia, Brasil e México, por exemplo, possuíam características comuns sendo, por isso, possível conferir a eles duas identidades, ou elementos distintivos. Uma de caráter política, que os entende como system-affecting states, aqueles com perfil internacional assertivo, mas que diante de suas limitadas capacidades quando comparados aos países desenvolvidos, valorizam as arenas multilaterais e a ação coletiva com seus pares para de algum modo exercer poder e influência no plano internacional e outra de caráter econômico, que os caracteriza enquanto grandes mercados emergentes, implementadores das reformas econômicas propostas pelo Consenso de Washington, de 1989. As negociações Sul-Sul, deste modo, apontam para o protagonismo político da coalizão "terceiro-mundista", em que a cooperação aparece como a afirmação da identidade desta coalizão, como ocorrido na década de 1960 com a criação do Grupo dos 77 (G77).

As relações brasileiras - sejam elas de qual natureza forem - com os países também em desenvolvimento não são fato recente, mas foi a partir da década de 2000 que elas adensaram-se substantivamente, dando força à tese segundo a qual, foi durante os dois governos de Luiz Inácio Lula da Silva (2003 - 2010), que a CSS ganhou maior expressão, ora através do maior engajamento com seus vizinhos sul-americanos ora por sua expansão a outros países localizados na África, Ásia e América Central.

Buscar-se-á testar este caráter inovador da PEB atribuído ao governo de Lula, a partir do emprego do modelo teórico do Ponctuated Equilibrium, apresentado no capítulo anterior, 
de forma a contribuir com a constatação intrínseca ao modelo que toma o presidente como um dos principais motores que concorrem para as alterações no âmbito das políticas públicas. Este pressuposto dialoga com os estudos mais gerais sobre a delegação e preponderância presidencial na agenda legislativa (capítulo 1); entretanto, visto que os papéis atribuídos a cada um dos poderes em matéria de política externa diferem de suas congêneres domésticas, uma vez que apenas ao Executivo é atribuída constitucionalmente a autorização para formulação de propostas, aquele tipo de análise centrada na disputa entre os poderes Executivo e Legislativo perderia força explicativa ${ }^{12}$. Não obstante, como isso ocorre no interior do Executivo, continua a ser uma questão preponderantemente importante e foco do capítulo que segue (e daqueles subsequentes).

Dito isso, entender como essa política é efetivada, significa a observação mais detida dos arranjos institucionais que, em última instância, são os responsáveis pelo seu funcionamento, sobretudo no interior dos ministérios, principais atores que atuam em todo o seu processo desde a formulação até a implementação. Evidentemente, a experiência brasileira nos diferentes continentes é muito diversa no sentido de possuir pontos de encontro e afastamento, de forma a tornar inviável, diante da limitação do espaço e de recursos, traçar um quadro exploratório mais amplo, de modo que o presente capítulo buscará fazer um breve levantamento de uma capilaridade específica da CSS, qual seja, a Cooperação Técnica entre Países em Desenvolvimento (CTPD), e mais especificamente, aquela realizada pelo Brasil no Haiti.

\section{Breve Histórico Internacional da CSS e da CTPD}

A Cooperação Técnica Internacional (CTI) foi instituída pela Resolução no 200 de 1948 da Assembleia Geral das Nações Unidas (AGNU), sob a rubrica de "assistência técnica", ainda no contexto da Guerra Fria. De acordo com Cervo (1994), as duas grandes potências à época, Estados Unidos e União Soviética, visavam dois interesses maiores: a montagem

\footnotetext{
${ }^{12}$ Diferentes trabalhos tratam da atuação e consequente importância atribuída ao poder legislativo na política externa (Lima e Santos, 2001; Diniz, 2012; Anastasia et al., 2012). Entretanto, conforme pôde ser visto no capítulo anterior, Sanchez et al., 2006, demonstram que a Constituição de 1988 garante ao Executivo um maior poder nas fases de formulação e decisão da política externa, ao passo que o legislativo atua mais no processo de (co)decisão a posteriori.
} 
de seus sistemas de aliança, respectivamente, a Organização do Tratado do Atlântico Norte (OTAN), em 1949, que teve como resposta o Pacto de Varsóvia, em 1955; além de buscarem preservar suas zonas de influência. Assim, o autor entende que a cooperação foi criada "em contexto estratégico, não tendo como único escopo o que lhe era próprio" (p. 38).

Ela foi articulada a partir de alguns pressupostos, entre os quais se previa i) a necessidade de desigualdade em relação ao desenvolvimento entre o país prestador e receptor e ii) a transferência de técnicas e conhecimentos de caráter não-comercial a partir da execução conjunta de projetos entre os países, a ser feita por intermédio de uma estrutura composta por peritos, equipamentos, estudos, pesquisas e treinamentos. Tomando em conta estes dois pressupostos, chegou-se ao entendimento de que a prática, antes de mais nada, representava uma relação de trocas, de modo que, posteriormente o termo "assistência" foi substituído por “cooperação”, pela Resolução no 1.383, em 1959 (Cervo, 1994).

Se até aquele momento o desenvolvimento era entendido como sinônimo de crescimento econômico, a partir da década de 1960, entretanto, iniciou-se um movimento por parte dos países em desenvolvimento, que culminaria na adoção da Declaração sobre o Direito ao Desenvolvimento pela Organização das Nações Unidas em 1986. Essa mudança remodelou o tema a partir das reivindicações desse grupo de países, que se colocava cada vez mais atuante no plano internacional.

Esse contexto deve-se a pelo menos duas importantes transformações ocorridas no plano internacional ao longo destas duas décadas: a emergente insatisfação dos países do então "Terceiro Mundo" com os resultados das políticas de desenvolvimento levadas a cabo pelos países desenvolvidos e o processo de descolonização de países na África e na Ásia. Em relação ao primeiro, os países em desenvolvimento perceberam que o referido processo não só não estava colaborando com o seu crescimento econômico, como também impedia-os de progredir socialmente, de modo que foi aberto um extenso debate sobre a forma pela qual as políticas de cooperação vinham sendo empregadas.

Em relação à segunda, embora tivesse sido instituída a Declaração sobre a Outorga da Independência aos Países e Povos Coloniais, em 14 de dezembro de 1960, pela Resolução $\mathrm{n}^{\circ} 1514(\mathrm{XV})$ da Assembleia Geral da ONU, condenando o colonialismo e as práticas de 
segregação e discriminação a ele associadas, as relações dos países recém independentes com suas antigas colônias ainda guardavam resquícios coloniais, que se traduziam no modo pelo qual as relações de trocas ainda eram conduzidas, bem como a permanência de lutas raciais e o apartheid em países africanos. Como nações soberanas, estes países passaram a integrar o conjunto das Nações Unidas em igualdade de condições formais com os países ricos, e a tornaram um foro privilegiado para suas reivindicações.

A ideia de um desenvolvimento justo que levasse em conta as reais necessidades dos países mais pobres foi, assim, estabelecendo-se aos poucos, figurando como um desdobramento de uma ideia ampla de autodeterminação dos povos, "na medida em que se apresenta como instrumento da verdadeira independência, da negação do colonialismo e do pleno acesso dos povos aos bens e direitos inerentes a um estágio de desenvolvimento que garanta bem-estar econômico e social de cada um dos cidadãos de um Estado nacional" (Campinho, 2010; p. 157). Aos poucos, embasados neste "ideal”, foi ficando cada vez mais eminente a necessidade do diálogo Sul-Sul, reunindo as nações do "Terceiro Mundo".

Um clássico marco histórico desta iniciativa ocorreu em 1963, quando do discurso proferido na abertura da $18^{\mathrm{a}}$ Assembleia Geral das Nações Unidas, pelo então chanceler brasileiro, João Augusto de Araújo Castro, que tratou exatamente desse ponto através de reivindicações em torno de três temas que ele considerava fundamental: desarmamento, desenvolvimento econômico e descolonização. Este foi um dos discursos mais conhecidos da história da diplomacia brasileira, que foi chamado de "Discurso dos Três D's". De acordo com o chanceler: "nem tudo é Este ou Oeste nas Nações Unidas de 1963. O mundo possui outros pontos cardeais. Esses termos, que dominavam toda a política internacional até há pouco tempo, poderão eventualmente ser devolvidos à área da geografia”. Para ele, a despeito dos esforços empreendidos pelos países em desenvolvimento, com poder de veto reduzido na Assembleia Geral da ONU, eles não conseguiam implementar suas recomendações em nenhum dos três itens (Castro, 1963).

Um ano depois, em Genebra, realizou-se a primeira Conferência das Nações Unidas sobre Comércio e Desenvolvimento (UNCTAD), e simultaneamente os países subdesenvolvidos estabeleceram o Grupo dos 77 (G77), delineando os primeiros traços de uma cooperação Sul-Sul. Na "Declaração Conjunta dos Setenta e Sete Países em 
Desenvolvimento feitas no final da Conferência das Nações Unidas sobre Comércio e Desenvolvimento", de 15 de junho de 1964, foi estabelecido no segundo parágrafo que, as premissas básicas de uma nova ordem "envolve[ria] uma nova divisão internacional do trabalho orientado para a industrialização acelerada de países em desenvolvimento. Os esforços dos países em desenvolvimento para aumentar os padrões de vida dos seus povos, que est[avam] a ser feitos sob condições externas adversas, deve[riam] ser complementados e reforçados por uma ação internacional construtiva" (Joint Declaration of the Group of 77, 1964).

Na prática, este discurso foi concretizado a partir de 1967, com a criação de organismos internacionais como o Programa das Nações Unidas para o Desenvolvimento (PNUD) e a Organização das Nações Unidas para o Desenvolvimento Industrial (ONUDI), que buscavam viabilizar a capacitação dos países subdesenvolvidos em áreas estratégicas, a partir do emprego de especialistas internacionais para atuar em projetos definidos e com o apoio financeiro para sua implementação. Em 1974, então, foi convocada a Conferência Mundial das Nações Unidas sobre Cooperação Técnica entre Países em Desenvolvimento, que se reuniu em agosto e setembro de 1978 na cidade de Buenos Aires, de modo que suas recomendações foram aprovadas na forma do Plano de Ação de Buenos Aires (PABA), que inaugurou a CTPD (Cervo, 1994; ABC, s/d).

De acordo com Lima (2005), estes países considerados emergentes possuem duas identidades que permitem reconhecê-los enquanto tal. A primeira trata-se de uma identidade política, que os iguala dada a reduzida capacidade em relação às grandes potências e por suas políticas assertivas conjugadas nas arenas multilaterais e coalizões com países do hemisfério Sul com o objetivo de alcançar um equilíbrio de poder e ao mesmo tempo influenciar os resultados internacionais. A segunda, por sua vez, tem um caráter econômico, que os une em função de serem grandes mercados da periferia que implementaram as reformas econômicas propostas pelo Consenso de Washington, de 1989.

Para tratar destas questões, ou antes da intersecção entre estas duas identidades, a autora busca nas raízes históricas o momento de confluência entre ambas e que possibilitou que estes países voltassem sua atenção e esforços para a implementação da Cooperação SulSul. É possível apreender que identidade política é anterior à identidade econômica nos 
termos estabelecidos pela autora, ou seja, tendo em vista a classificação de "países emergentes", uma vez que a primeira, começou a consolidar-se entre as décadas de 1960, quando foi levada a cabo uma "coalizão terceiro mundista" com a criação do G-77 em 1964, em que os países membros buscavam autonomia política ao mesmo tempo que preconizavam também a constituição de modelo desenvolvimentista justo (diferente daquele implementado pelos EUA desde a década de 1940), baseado nas relações comerciais, levando em conta as questões das desigualdades Norte-Sul muito presentes nas discussões internacionais neste momento. Já em 1989, diante de uma profunda crise em que se encontravam os países em desenvolvimento, estes optam pelas diretrizes econômicas propostas pelo Fundo Monetário Internacional (FMI), Banco Mundial e EUA.

É certo que essa qualificação esteve em seu início atrelada à indicadores de desempenho econômico, mas Hirst (2012) aponta que, em alguns casos, alguns destes países demonstraram grande influência em questões políticas e de segurança global, de modo a possibilitar uma reconfiguração do rótulo "economias emergentes" para "poderes emergentes", o que significou, em última instância, um processo de reordenamento do sistema internacional devido à busca por maior espaço de atuação e influência nos campos político, econômico e militar.

\section{A CTPD no Brasil}

No Brasil, o desenrolar deste contexto ao longo das últimas décadas foi marcado pela disputa, a depender do governo em exercício, de duas vias distintas para a consecução de tais interesses, ora uma perspectiva cosmopolita que defendia uma relação privilegiada com países desenvolvidos, sobretudo os EUA, ora uma visão aqui entendida como realista, que buscava a afirmação de sua identidade como um país também em desenvolvimento e que por isso privilegiava relações mais estreitas com os demais países do Sul (Hirst, 2012). O ponto de maior inflexão destas alternâncias, em que a segunda aparece com maior força, foi durante o governo do ex-presidente Lula, em que a política externa passou a ser vista como um instrumento e complemento externo da estratégia de desenvolvimento adotada internamente. 
A CTPD alcançou ao longo de sua evolução no Brasil, desde pelo menos o final da década de 1978, quando foi aprovado o Plano de Ação de Buenos Aires, pela ONU, relevante e exponencial crescimento, ora atrelada aos níveis burocrático-institucionais ora como política afirmativa de inserção internacional por parte do Executivo. Embora o Brasil atue como país cooperante desde as décadas de 1950 e 1960, é principalmente a partir de 1970 que a CTPD passou a ser praticada com maior ênfase. Dois fatores importantes concorrem para esta mudança: i) o período de rápida industrialização, conhecido como o "milagre econômico", que além das transformações econômicas, gerou forte apelo emocional e consequente compartilhamento de um sentimento ufanista, o que por sua vez, possibilitou, em alguma medida; ii) a busca por uma inserção externa afirmativa que enfatizava o slogan "Brasil Potência"13.

Em conjunto, estes dois elementos contribuíram para a aproximação brasileira com os países em desenvolvimento ora objetivando constituir relações com novos mercados para importação e exportação, ora defendendo uma nova ordem nas relações internacionais que favorecesse seus interesses e que conferisse ao país um papel de significativa importância ${ }^{14}$. Deste modo, é neste contexto que o Itamaraty, não obstante as pressões contrárias, opta por uma orientação de caráter globalista que confere espaço privilegiado para as políticas desenvolvidas com estes países, incluindo a CTPD (Lima, 2005; Oliveira, 2005).

Conforme visto na seção anterior, para Kingdon (2006), a esfera política funciona de modo independente dos demais fluxos que influenciam a construção da agenda e consequentemente, o processo de tomada de decisão. Assim entendido, mudanças na

\footnotetext{
${ }^{13}$ De acordo com Lima (2005) a cooperação brasileira esteve fortemente ligada a fatores como o fortalecimento e expansão industrial na década de 1970, que necessitava de novas parcerias comerciais, sobretudo para a exportação de sua produção. Esta, por sua vez, criou profundas raízes na sociedade brasileira, com influência direta na política externa por duas razões: i) fortaleceu-se a legitimidade do Ministério das Relações Exteriores (MRE) que passou a ser visto como um dos mais importantes instrumentos do projeto desenvolvimentista do país e ii) este legado permaneceu presente na memória institucional do MRE, mesmo quando do fim deste modelo, sendo que esta percepção perduraria por anos, e em certa medida é possível dizer que perdura até os dias atuais.

${ }^{14}$ Esta última, guardadas as devidas particularidades de cada Estado, não era uma defesa unicamente brasileira, ao passo que no plano internacional passaram a emergir outros países do Sul aliados pela causa terceiro-mundista, o que teria significado, grosso modo, uma coalizão questionadora da divisão internacional do trabalho no interior da qual lhes cabia o papel de mero fornecedores de matéria-prima e importadores de capital e tecnologia (Oliveira, 2005).
} 
atmosfera política - que podem ser resultado de transformações ocorridas tanto no campo social e econômico, quanto no institucional, a exemplo das eleições que trazem novas configurações partidárias e ideológicas -, são elementos extremamente significativos para o reconhecimento de questões consideradas importantes e que devem, por isso, integrar a agenda.

A fim de verificar a evolução da CTPD na agenda de política externa no Brasil, foram recolhidas no site da Câmara dos Deputados, as proposições enviadas pelo presidente em exercício, no período que compreende quatro décadas, com início no ano de 1970 no governo de Ernesto Geisel, terminando em 2010, último ano do segundo mandato do presidente Lula. O objetivo foi verificar a importância atribuída à CTPD na agenda do presidente testando, desta forma, o modelo do Ponctuated Equilibrium de Baumgartner e Jones (1993), vista no capítulo anterior, com foco nas mudanças institucionais, que segundo os autores, são um dos principais elementos responsáveis por interferir nas políticas públicas que são adotadas. No Brasil, o decorrer de quarenta anos trouxe transformações não apenas de caráter institucional, mas de regime político, mudanças sociais e econômicas, que alteraram, via de regra, as orientações adotadas por cada presidente. Assim, analisar a política de CTPD empreendida pelo governo, à luz da teoria supracitada, possibilita verificar as variações temporais.

Optou-se por agrupar os mandatos dos oito diferentes presidentes que compõem o universo em três grupos conformando, não homogeneamente, o período de três décadas, a fim de facilitar a exposição e comparação dos dados. O primeiro compreende os anos de 1970 e a primeira metade de 1980; o segundo grupo compreende o ano de 1985 até início da década de 1990, e o terceiro é composto pelo período que vai de 1995 a $2010^{15}$. Esta junção que, a princípio, aparentou ser meramente funcional, possibilitou que fossem encontrados também três períodos distintos na atenção conferida ao tema na agenda do Executivo e na evolução da política de CTPD, constituindo momentos de equilíbrio e pontuação.

\footnotetext{
${ }^{15}$ Grupo I: Emílio Garrastazu Médici (1970-1973), Ernesto Geisel (1974-1978) e João Batista Figueiredo (1979-1984). Grupo II: José Sarney (1985-1989), Fernando Collor de Melo (1990-1992) e Itamar Franco (1992-1994). Grupo III: Fernando Henrique Cardoso (1995-2002) e Luiz Inácio Lula da Silva (2003-2010).
} 
Foram recolhidas no site da Câmara dos Deputados as preposições de Acordos de Cooperação enviadas pelo poder Executivo entre os anos de 1970 e 2010, totalizando 469. Neste universo encontram-se inclusas não apenas aquelas referentes à Cooperação Técnica, mas também à Cooperação Financeira, Comercial e Científica \& Tecnológica, tanto com países desenvolvidos como em desenvolvimento. Posteriormente foram separadas apenas as preposições que versavam sobre Cooperação Técnica, por meio de critério atribuído pelo texto da própria ementa da proposição ou da indexação da proposta, abrangendo diferentes áreas ${ }^{16}$. Mesmo aquelas proposições que possuem dois ou mais tipos de cooperação em um mesmo Acordo, conquanto também incluísse "Cooperação Técnica" foram consideradas sem prejuízos à pesquisa.

Após isso, os Acordos de Cooperação foram classificados de acordo com o nível de desenvolvimento dos países, seguindo a divisão do FMI, extraídas do relatório publicado em 2014 ${ }^{17}$, resultando em dois grupos: Países Desenvolvidos e Países em Desenvolvimento, restando, então, 311 proposições. Destas, foram excluídas aquelas retiradas pelo próprio Executivo no decorrer do processo de votação, ao passo que os demais casos, como "Arquivadas", "Em tramitação no Plenário" ou "Aguarda retorno do Senado", foram mantidas, dado que o interesse principal foi analisar o peso atribuído à iniciativa do Executivo na variação temporal da política de CTPD.

\footnotetext{
${ }^{16}$ As áreas recorrentes encontradas foram Educação, Cultura, Saúde, Agropecuária, Meio Ambiente, Turismo e Defesa, além dos próprios Acordos Básicos, que são os documentos essenciais para a execução de qualquer tipo de Cooperação. As proposições foram encaminhadas à Comissão de Relações Internacionais e Defesa da Câmara dos Deputados, e posteriormente votadas e transformadas - ou não em um Decreto Legislativo (DL), concernente a Acordos, Tratados ou Atos Internacionais. Uma vez aprovado o Acordo a responsabilidade pela gestão dos projetos passa a ser da Agência Brasileira de Cooperação $(\mathrm{ABC})$. Os números de projetos, obviamente, ultrapassam em muito as proposições aqui analisadas, mas diante da impossibilidade de trabalhar com todos os projetos firmados entre o Brasil e outros países em desenvolvimento, em função do trabalho a ser empreendido para isso e a indisponibilidade de acesso facilitado aos dados, essa opção foi descartada.

${ }^{17}$ Entende-se que no decorrer de quatro décadas esta classificação passou por inúmeras transformações conforme a evolução no desenvolvimento dos países, no entanto, o universo de países desenvolvidos, de acordo com o FMI, sempre foi reduzido, integrando sobretudo os países do hemisfério Norte, e como a pesquisa considera apenas os países em desenvolvimento que não integraram o outro grupo, isso não acarretará maiores prejuízos à pesquisa, devido a uma provável margem de erro, como no caso de países como Japão e alguns países europeus que sofreram alterações econômicas durante as décadas de 1970 e 1980.
} 
Outra nota metodológica importante é que apenas foram mantidas as proposições de cooperação bilateral, ou seja, aquelas estabelecidas entre o Brasil e outro país, sendo excluídas as propostas multilaterais diante do fato de que foros como a Organização das Nações Unidas (ONU), Comunidade dos Países de Língua Portuguesa (CLP) ou Organização dos Estados Americanos (OEA), por exemplo, agregam países desenvolvidos e em desenvolvimento. Diante destes recortes, o universo analisado foi composto de 276 proposições de Acordo de Cooperação Técnica solicitadas pelo Executivo.

No primeiro período é possível identificar a criação e manutenção de um feedback positivo gerado pela boa imagem política da CTPD, fruto de contextos internos e externos que favoreceram sua paulatina ampliação. Durante o segundo período passa a ocorrer uma saturação, ou mesmo quebra desta imagem, resultado de uma crise econômica interna que se converteu em feedback negativo para sua manutenção. No terceiro período, o tema volta a receber destaque na agenda em função da imagem política novamente positiva, mas agora somada a uma atuação mais assertiva do Executivo, gerando feedbacks positivos e, consequentemente, grandes mudanças pontuais. O gráfico 1, representa esta variação temporal a partir da comparação entre a quantidade de proposições de Acordos de CTPD enviadas por cada presidente.

Gráfico 1. Número de Proposições de Acordos de CTPD por Mandato (1970 - 2010)

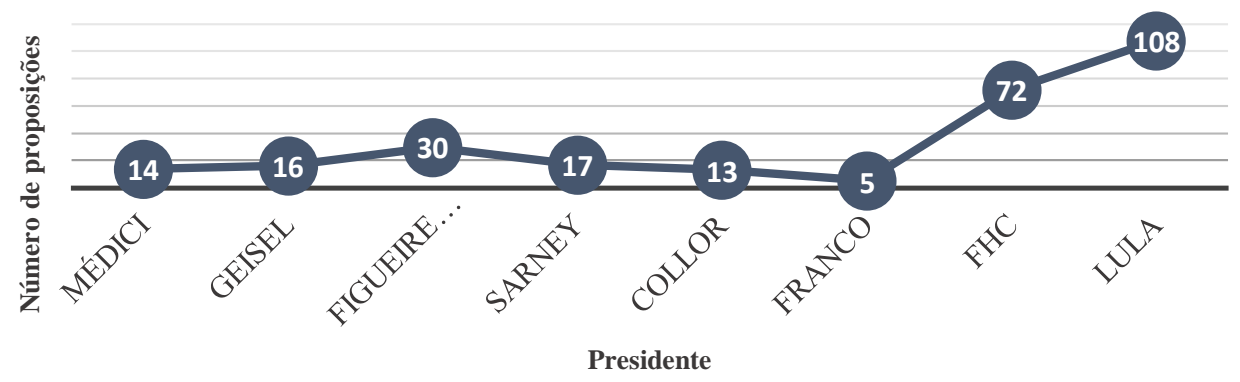

Fonte: Câmara dos Deputados: http://www2.camara.leg.br/ (Acesso em 27 de julho de 2014)

É possível perceber que ao longo de quatro décadas a política de CTPD esteve em crescimento no primeiro período, em queda no segundo e demonstra amplo crescimento no terceiro. No entanto, a afirmação é válida se observada sob esta perspectiva longitudinal por mandato, pois quando observado ano a ano de cada administração, todos 
os períodos, sem exceção, são caracterizados por momentos intercalados de equilíbrio e pontuação. Por essa razão privilegiou-se, na pesquisa, os mandatos presidenciais que oferecem uma percepção mais nítida sobre a atenção conferida à política na agenda quando analisadas as quatro décadas.

Não obstante, ao utilizar como aporte teórico o modelo do Ponctuated Equilibrium, não se pretende apenas demonstrar estas variações temporais sofridas pela CTPD, mas também buscar investigar a razão deste processo, de maneira que a principal questão "por que houveram períodos de equilíbrio e pontuação", apenas pode ser respondida a partir da análise detalhada de cada um dos períodos definidos a priori. O quadro abaixo oferece uma breve síntese dos achados:

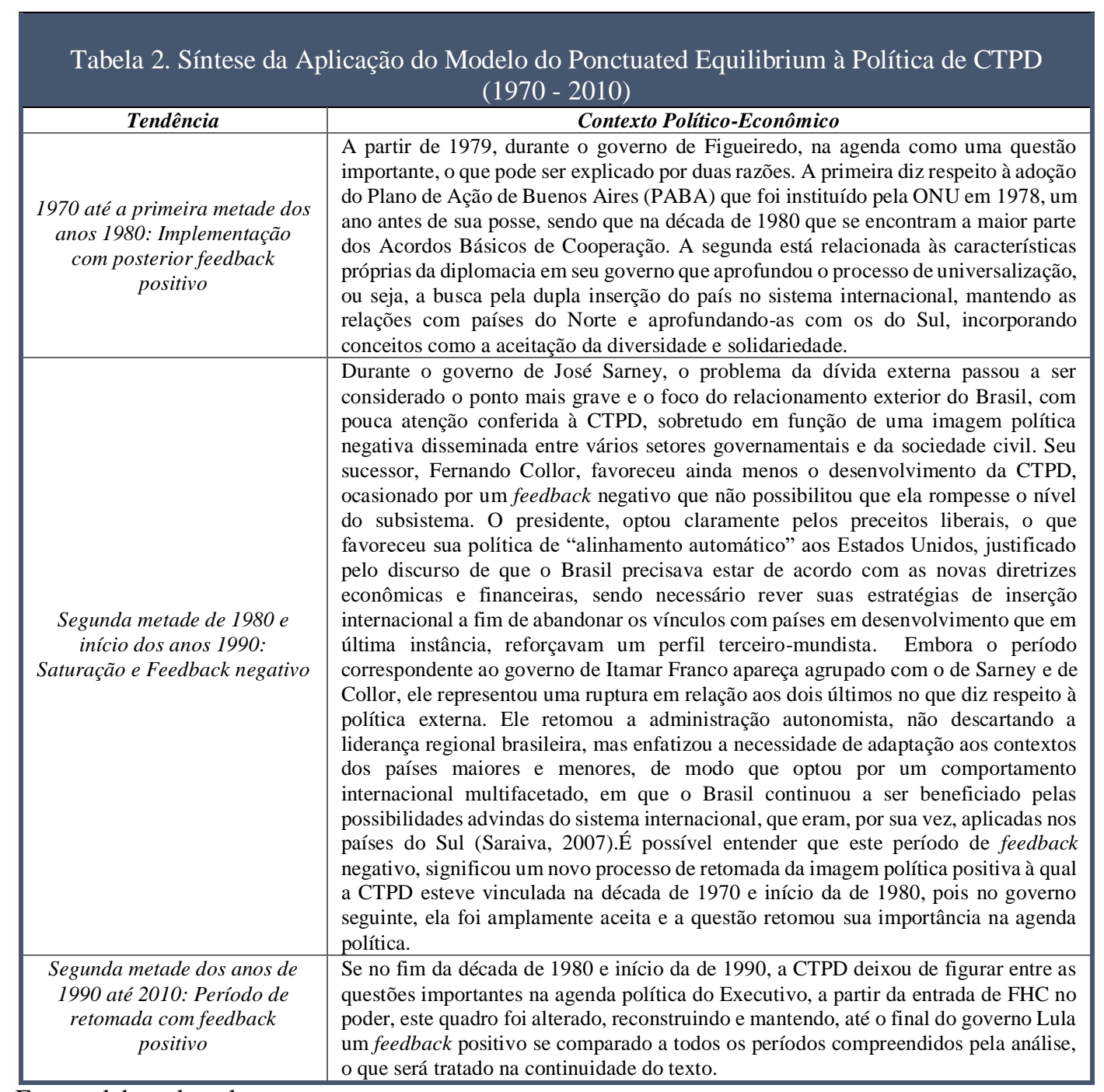

Fonte: elaborado pela autora 
Se entre as décadas de 1980 e 1990, a política de CTPD não tinha força na agenda presidencial, de modo que ocupou, em seu início, espaço secundário da atenção dos líderes políticos, a partir dos anos 2000 houve um crescimento do total de projetos enviados desde o início do primeiro mandato de FHC, sendo que foi a partir de 2003, no governo Lula, que a política passou a ser empreendida de maneira nunca antes observada.

Gráfico 2. Proposições de Acordo de CTPD (1995-2010)

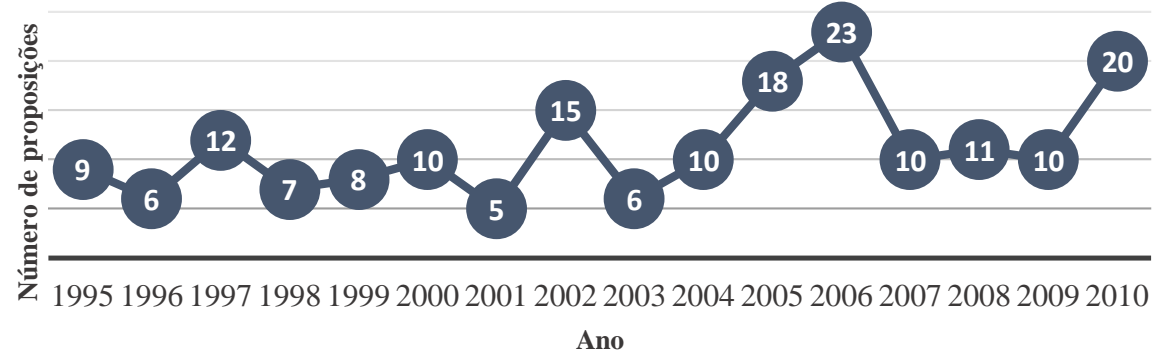

Fonte: Câmara dos Deputados: http://www2.camara.leg.br/ (Acesso em 27 de julho de 2014)

O que os números mostram é que desde a entrada de FHC no poder, até o final do governo Lula, houve um feedback positivo da CTPD. Isto pode ser explicado pelo fato de que para este momento específico pode-se falar, de forma mais geral, em um processo de mudança incremental, com amplas pontuações a partir de 2006. A principal diferença no ambiente institucional no período encontra-se na própria alternância de poder no cargo do Executivo, entre dois partidos polarizados ideologicamente, o PSDB e o PT. O governo FHC, ligado ao primeiro, aliou os paradigmas institucionalista pragmático e o autonomista com predominância do primeiro, sem, no entanto, abandonar a tese partilhada ao longo dos anos de que o Brasil deveria ocupar um lugar especial no cenário internacional tanto em termos políticos quanto estratégicos.

O seu discurso de política externa foi sustentado pelo conceito conhecido como soberania compartilhada, em que se por um lado, os Estados Unidos era tido como um país com grandes recursos de poder, ele não poderia gestar esta ordem sem a adesão de outras potências. Por outro lado, o Brasil, enquanto ator unitário, não teria poder frente a ele, de modo que o alinhamento a países igualmente menos poderosos, seria capaz de conferir um certo equilíbrio na configuração das relações internacionais. Assim, FHC buscou fortalecer os laços regionais com a América do Sul através do diálogo com o Mercosul, 
ao mesmo tempo em que se aproximou de outras potências consideradas médias e de grande porte, destacando-se nesses casos Índia, China, Rússia e África do Sul, sem perder de vista, entretanto, uma implícita motivação comercial (Saraiva, 2007; Vizentini, 2012).

A imagem política acerca da CTPD sofreu grandes alterações quando passaram a ser enfatizadas tanto no discurso diplomático quanto do Executivo as obrigações brasileiras para com os países do Sul, baseadas em trocas de aporte técnico, de base científica e tecnológica, processo inaugurado pela entrada de Lula na presidência, que se voltou completamente à orientação autonomista. É inegável o peso a ser atribuído a suas próprias características pessoais e às bases ideológicas que orientaram a formação do PT, primeiro partido de esquerda a conquistar a eleição no país, significando, entre outras coisas, grandes mudanças no ambiente institucional. Esta questão já foi amplamente discutida no capítulo 1, de modo que aqui faz-se apenas pertinente frisar que esta nova postura do Executivo diante das questões relativas à CTPD possibilitou uma mudança pontual na política nunca antes alcançada.

O COBRADI, relatório publicado em 2010 pelo IPEA em conjunto com a Agência Brasileira de Cooperação (ABC), apresentou as primeiras informações sistemáticas sobre a CSS. No relatório aparecem sete diferentes modalidades de investimento dos recursos brasileiros para a cooperação internacional: i) cooperação técnica; ii) cooperação educacional; iii) cooperação científica e tecnológica; iv) cooperação humanitária; v) apoio e proteção a refugiados; vi) operações de manutenção de paz e vii) gastos com organismos internacionais (ABC e IPEA, 2010). Embora, na prática, seja muito difícil isolar as diferentes modalidades de cooperação, sobretudo as três primeiras, e em alguma medida a quarta, - fato comprovado quando da leitura dos Acordos de Cooperação - esta primeira iniciativa possibilitou uma visão mais pormenorizada de como o Brasil tem organizado sua ação cooperativa no arranjo Sul-Sul.

As políticas sociais do governo do ex-presidente Lula ganharam repercussão positiva interna e externamente, em grande medida em função de um duplo engajamento no qual ao mesmo tempo em que se privilegiava a diminuição e mesmo a eliminação dos problemas socioeconômicos brasileiros, perseguia-se uma inserção internacional voltada não apenas para os aspectos comerciais, mas que operasse também como um instrumento 
e complemento externo da estratégia de desenvolvimento adotada internamente (Vizentini, 2012; Hirst, 2012; Pimenta de Faria, 2012a).

Não obstante, não se pode perder de vista que esta linha de ação adotada era perpassada pela intensificação das relações com os países do Sul, sendo esta última resguardada pelo discurso do "humanismo" e da "solidariedade", o que acabou colaborando para a criação do ambiente propício à ampliação e concretização da política de Cooperação Sul-Sul. O reforço dado à CSS possibilitou então, a ampliação da ajuda internacional brasileira na forma de recursos tanto financeiros quanto científicos e tecnológicos e, consequentemente, a abertura do espaço para a consolidação de um novo papel para o Brasil, que passava da condição de país "importador" para "exportador" de programas e políticas, agora operadas entre ele e os demais países em desenvolvimento. O Bolsa Família e o Fome Zero, embora não únicos, são os casos mais emblemáticos de programas amplamente reconhecidos pela comunidade internacional como práticas a serem difundidas e implementadas pelo mundo. Esta difusão, por sua vez, encontrou materialidade por meio da CTPD (Pimenta de Faria, 2012b; Milani, 2014).

De acordo com a $\mathrm{ABC}^{18}$, a CT atua como um pilar da Cooperação Internacional, sendo entendida pelo governo como um instrumento privilegiado capaz de possibilitar que as relações do Brasil com demais países sejam adensadas por meio da integração política, econômica e social. No entanto, não se deve entender os países parceiros como simples receptores passivos, mas como os principais agentes da mudança esperada, de modo que o governo não trata a CT em termos de uma transferência mecânica ou mera transplantação de práticas exógenas sem atenção ao contexto local. Ao contrário, o principal objetivo de um determinado projeto de cooperação técnica é fortalecer a capacidade dos agentes locais em desenvolver respostas endógenas aos seus problemas que, em alguma medida, encontram similaridade com aqueles já enfrentados e superados no Brasil - através do intercâmbio de conhecimentos e experiências entre os dois países (ABC, 2013).

\footnotetext{
${ }^{18}$ A responsabilidade formal de coordenar, negociar e supervisionar tanto os projetos de cooperação técnica recebidos do exterior, quanto os quais o Brasil é provedor fica a cargo da $\mathrm{ABC}$, sendo as iniciativas de CTPD reguladas pelos Acordos Básicos de Cooperação, que por sua vez, estão sujeitos à aprovação legislativa e por Ajustes Complementares e Documentos de Projetos.
} 
Em termos de dados concretos relativos à operacionalização da CT, o COBRADI, menciona que houve aumento dos gastos do governo brasileiro entre os anos de 2005 e 2010, passando de R \$ 25 milhões para R \$ 101 milhões. Quando distribuídos pelas regiões onde encontram-se os países com os quais o Brasil cooperou no ano de 2010, ano de publicação do relatório, tem-se a seguinte classificação: América Latina e Caribe com $53,3 \%$ dos investimentos com foco em iniciativas pontuais; África com 39,5\% dos investimentos direcionados a projetos estruturantes e Ásia com 7,0\%. Em números de ações, liderou majoritariamente o Haiti com investimento no valor de $\mathrm{R} \$ 9.953 .934$, seguido pelo Peru com R\$5.361.837; São Tomé e Príncipe, R \$5.160.787 e Moçambique com R\$5.093.786 (ABC e IPEA, 2010; Leite et al.,2013).

Tanto o alto percentual de investimento na macrorregião que compreende a América Latina e o Caribe, quanto o destacado envio de recursos para o Haiti podem ser explicados, em boa medida, em função do terremoto que ocorreu no país em 12 de janeiro de 2010. Parte deste recurso foi resultado da Medida Provisória n 480 (MP 480/10), enviada ao Congresso em regime de urgência em 27 de janeiro pelo então presidente Lula, com o objetivo de abrir um crédito extraordinário no valor de $\mathrm{R} \$ 1,374$ bilhão para reforçar o orçamento de vários órgãos da administração pública no atendimento às populações vítimas de desastres naturais, tanto no Brasil (devido às catástrofes provocadas pelas fortes chuvas na época) quanto no Haiti, com recursos destinados à reconstrução do país. A MP foi aprovada em 18 de maio e promulgada na Lei 012.239 de 2010 em 19 de maio. Embora a área da agricultura não tenha integrado o conjunto de ações emergenciais do governo brasileiro; junto à saúde, ela figura com grande proeminência na implementação de projetos de cooperação no país entre os anos de 2005 e 2010.

Antes de tratar propriamente dos projetos de CTPD brasileiros no Haiti, é importante discutir o contexto específico das relações entre o Brasil e os países da América Central e Caribe, grandemente impulsionadas pela sua participação na MINUSTAH. Embora tenha havido um substancial aumento da participação do Brasil na região do Caribe, o governo já executava atividades naquele continente através da Comunidade dos Estados Latino-Americanos e Caribenhos (CELAC) - que congregou o Grupo do Rio e a Cúpula da América Latina e do Caribe sobre Integração e Desenvolvimento - e da Comunidade do Caribe (CARICOM) 


\section{I) Grupo do Rio - CALC - CELAC}

Décadas antes da aproximação do governo brasileiro com o Haiti, já existia um instrumento de diálogo entre países da América do Sul com seus vizinhos da América Central e do Caribe. A Declaração do Rio de Janeiro de 1986 instituiu o Mecanismo Permanente de Consulta e Concertação Política (Grupo do Rio) firmado pela Argentina, Brasil, Colômbia, México, Panamá, Peru, Uruguai e Venezuela. O objetivo de sua criação foi a instalação de um mecanismo regional de diálogo e concertação política inserido em um contexto histórico marcado pela instabilidade política e por intervenções norteamericanas na América Central. Após esse período, dadas as alterações ocorridas nesse cenário, o Grupo passou a ocupar um importante espaço como foro privilegiado de discussões sobre temas de interesse à região, como questões de estabilidade política e preservação de valores democráticos e instituições do Estado de Direito. Além disso, passou a servir como instrumento de comunicação entre chefes de Estado e chanceleres dos países membros entre si, e com outros blocos regionais, como é o caso da União Europeia (UE), com a qual é mantido um diálogo institucionalizado. No período referente ao recorte histórico da pesquisa, foram realizadas cinco Cúpulas do Grupo do Rio, ao passo que a última, conforme será visto na sequência, possuiu um importante caráter político (MRE, 2010).

Posteriormente à criação do Grupo do Rio, coube ao Brasil, a iniciativa de convocar a I Cúpula da América Latina e do Caribe sobre Integração e Desenvolvimento, realizada entre os dias 16 e 17 de dezembro de 2008 na Bahia, na qual estiveram presentes todos os 33 países da região, resultando na Declaração de Salvador que instituiu a CALC. A CALC é entendida como um foro de cooperação em temas relacionados ao desenvolvimento e à integração regional da América Latina e Caribe, tendo dois principais objetivos: i) a promoção do desenvolvimento socioeconômico e ii) o estabelecimento de diretrizes de cooperação entre os mecanismos regionais e subregionais de integração, partindo do pressuposto que os países latino-americanos e caribenhos compartilham dos mesmos desafios em relação a esses objetivos.

Para a consecução de tais desafios, é importante destacar a adoção do Plano de Ação de Montego Bay, instituído em 6 de novembro de 2009 na Jamaica, quando da reunião dos 
ministros das Relações Exteriores dos países membros da CALC. O plano estabeleceu a necessidade do diálogo e da cooperação com vistas a estabelecer a convergência de esforços em áreas prioritárias, dentre as quais destacou: i) econômica-comercial; ii) produtiva; iii) social e institucional; e iv) cultura. No Brasil, previu-se a participação ativa de seus Ministérios e suas respectivas competências.

Não obstante, o ponto de encontro entre estas duas iniciativas, que ocorreu entre os dias 22 e 23 de fevereiro de 2010 em Cancún, foi chamada de Cúpula da Unidade. O encontro congregou a XXI Cúpula do Grupo do Rio e a II CALC, a partir do qual decidiu-se pela fusão destes dois foros através da criação da Comunidade dos Estados Latino-Americanos e Caribenhos (CELAC), que, grosso modo, buscou incorporar os patrimônios do Grupo do Rio no que tange à concertação política e da CALC, em relação à integração e ao desenvolvimento.

\section{II) CARICOM}

A partir de 2004, o Brasil passou a ser um país observador junto à Comunidade do Caribe $(\mathrm{CARICOM})^{19}$, muito em função de sua participação ativa na MINUSTAH. De acordo com o MRE (2010), isso ocorreu pelo fato de que a missão “ensejou o fortalecimento das relações entre a região e o Brasil, que passou a ser mais procurado por países caribenhos como alternativa para projetos de cooperação e parcerias para o desenvolvimento" (p. 93).

Ainda de acordo com o MRE, isso é claramente evidenciado por pelo menos quatro indicadores: i) a quantidade de visitas realizadas pelo então presidente Lula a países caribenhos, como a Jamaica, Trindad e Tobago, Haiti e República Dominicana; ii) a abertura de embaixadas residentes nos países da Comunidade ${ }^{20}$; iii) o alto fluxo de

\footnotetext{
${ }^{19}$ Antiga 'Comunidade e Mercado Comum do Caribe' é a atual 'Comunidade do Caribe', um bloco de países para a promoção da cooperação econômica e política, criada em 04 de julho de 1973 com hoje quinze membros (Antígua e Barbuda, Bahamas, Barbados, Belize, Dominica, Granada, Guiana, Haiti, Jamaica, Montserrat, Santa Lúcia, São Cristóvão e Névis, São Vicente e Granadinas, Suriname, Trinidad e Tobago) e cinco territórios associados (Bermudas, Ilhas Virgens Britânicas, Turks e Caicos, Ilhas Caimán, e Anguilla).

${ }^{20}$ Até 2005 haviam sido abertas oito embaixadas residentes: (Belize, Bahamas, Santa Lúcia, Granada, Antígua e Barbuda, Dominica, São Vicente e Granadinas e São Cristóvão e Névis).
} 
missões de cooperação destinadas à região (9\% das iniciativas brasileiras) e iv) o substantivo aumento do intercâmbio comercial entre o país e a região a partir de $2003^{21}$.

Em 26 de abril de 2010, ocorreu em Brasília, a I Cúpula Brasil-CARICOM com o objetivo de favorecer o avanço do diálogo político entre os envolvidos de modo a reforçar os laços históricos e culturais a fim de traçar objetivos comuns. Nela, foram tratado temas como a reforma das instituições financeiras e políticas internacionais, o auxílio na reconstrução do Haiti, a integração latino-americana e caribenha e a intensificação da cooperação em diferentes frentes. Em relação a este último, foram assinados 48 acordos bilaterais de cooperação em áreas como: agricultura, saúde, educação, cultura, entre outros (MRE, 2010).

\section{A CTPD Brasileira no Haiti}

A presença maciça do governo brasileiro no Haiti apenas pode ser entendida a partir de seu envolvimento na MINUSTAH. A Missão foi o resultado da incorporação da dimensão humana no campo da segurança coletiva, reconfigurando o caráter das Peacekeeping Operations (as missões de paz). A proteção de populações civis, refugiados e deslocados internos a partir de mandatos específicos, por exemplo, tornaram-se características fundamentais das novas missões de paz, nas quais os mandatos incluem estabilização, promoção da democracia e dos direitos humanos.

Com o passar das décadas, o Brasil incorporou dispositivos de reconhecimento e proteção aos direitos humanos em sua ordem jurídica, ainda que do ponto de vista formal, já que independentemente da ordem política estabelecida - democrática ou ditatorial - a

\footnotetext{
${ }^{21}$ Durante o período 2002-2009, as exportações brasileiras para os países do Caribe cresceram de US\$ 880 milhões em 2002 para US\$ 5 bilhões em 2009 (aumento de 472,7\%). As importações brasileiras provenientes dos países do Caribe cresceram de US\$ 53 milhões em 2002 para US\$ 514 milhões em 2009 (aumento de 869,80\%). O intercâmbio comercial (exportações mais importações) do Brasil com os países do Caribe cresceu de US\$ 933 milhões em 2002 para US\$ 5,5 bilhões em 2009 (aumento de 495,4\%). O superávit comercial do Brasil com os países do Caribe passou de US\$ 827 milhões em 2002 para US\$ 4,5 bilhões em 2009 (aumento de 447,6\%). Até agosto de 2010, o intercâmbio comercial do Brasil com os países do Caribe Central havia atingido US\$ 4 bilhões, ou 73,3\% do intercâmbio comercial do ano passado (MRE, 2010).
} 
aplicação destes dispositivos, nunca foi realizada de maneira integral e/ou universal. De qualquer forma, foi no período correspondente ao regime militar (1964-1985), que o país mais se afastou das normativas internacionais, justamente em um momento de grandes avanços na temática de direitos humanos. Os Pactos Internacionais de Direitos Humanos estabelecidos pela ONU em 1966, foram ratificados pelo Brasil em 1992, decorridos já cinco anos do retorno à democracia ${ }^{22}$. Este processo foi marcado pela promulgação da Constituição de 1988, que consagrou os direitos fundamentais, à luz do princípio da dignidade humana, como fundamentos do Estado Democrático de Direito, passando, ademais, a estabelecer uma correlação positiva entre a democracia e a política externa, e a garantir aos tratados de proteção de direitos humanos um privilegiado status de norma constitucional (Filho, 2007; Piovesan, 2009).

Se no âmbito externo, o fim da Guerra Fria e o processo de globalização alteraram profundamente o cenário internacional, internamente, o fim do regime militar resultou na busca por maior credibilidade externa, empreendida através de uma nova postura que incluía a adoção de uma agenda política que contemplava temas multilaterais, como direitos humanos e meio ambiente ${ }^{23}$, questões humanitárias, liberdade econômica e

${ }^{22}$ Em 1946 foi criada a Comissão de Direitos Humanos (CDH), encarregada da elaboração de uma Declaração Universal (plano da orientação) e de uma Convenção de Direitos Humanos (plano da implementação). Em 1948 foi adotada pela Assembleia Geral, por 48 votos a favor e por oito abstenções, a Declaração Universal dos Direitos Humanos, uma vis directiva, reconhecida como marco jurídicopolítico, pela comunidade internacional com a finalidade de listar os direitos considerados essenciais para garantir a inviolabilidade da dignidade do ser humano. Se a elaboração da Declaração Universal deu-se relativamente sem maiores dificuldades, contando com o consentimento da quase totalidade dos Estados partes, até o ano de 1951 não havia consenso para o estabelecimento de uma Convenção/Pacto Internacional de Direitos Humanos, que representaria, por sua vez, um instrumento internacional de caráter vinculante. A discordância Leste/Oeste representava um embate ideológico ocasionado pela bipolaridade que caracterizou o período da Guerra Fria - bloco capitalista, representado pelos Estados Unidos, e o bloco comunista, liderado pela antiga União Soviética - de forma a dificultar o estabelecimento de um consenso sobre a atribuição de significado e prioridade dada aos diferentes grupos de direitos. Dessa forma, a ideia original de elaborar uma única convenção que pudesse reunir o conjunto de direitos foi abandonada, e em seu lugar foram estabelecidos dois Pactos, um relativo aos direitos civis e políticos, outro aos direitos econômicos, sociais e culturais (Lafer, 1999; Reis, 2006).

${ }^{23}$ Em 1992, o país foi anfitrião da Conferência das Nações Unidas sobre o Meio Ambiente e Desenvolvimento, ocorrida na cidade do Rio de Janeiro, mais conhecida como Rio 92. Um ano após a Conferência, a representação do Brasil ocupou um importante papel no processo de redação da declaração final da Conferência de Viena. À adesão às normas do sistema internacional foram acrescidas a aceitação da competência da Corte Interamericana de Direitos Humanos, em 1998, e a adesão ao Tratado de Roma, que criou o Tribunal Penal Internacional, em 2000. 
igualdade de condição para competição, combate ao narcotráfico e ao crime organizado, soluções multilaterais a crises regionais, entre outros (Brigagão, 2012).

A partir dos anos 2000, houve um significativo avanço da economia, de um lado, e o incremento de políticas públicas em diferentes áreas, de outro, que trouxeram, entre outros resultados, crescimento econômico, diminuição da desigualdade de renda, redução da taxa de desemprego e pobreza (Freitas et al., 2012). No cenário internacional, o resultado desses esforços empreendidos pelo governo no nível interno, aliado aos de sua influência em termos de política e segurança global, externamente, possibilitaram a projeção do Brasil como um "país emergente", passando a se destacar pela sua capacidade de oferecer cooperação internacional, de tal modo que teria aumentado o escopo de suas responsabilidades e compromissos com os países em desenvolvimento. Dentre essas, destacam-se: responsabilidade militar e policial em cenários de reconstrução pós-bélicas, de crises humanitárias ocasionadas por diferentes fatores, de busca pela paz, estabilidade e desenvolvimento sustentável, entre outros (Hirst, 2012).

Lula enfatizou a maior atenção que seria disponibilizada pela diplomacia brasileira à América do Sul, bem como a sua disposição em contribuir com a solução pacífica de crises em países vizinhos baseada no diálogo, nos preceitos democráticos e nas normas constitucionais de cada Estado. Nunca havia sido anunciada semelhante disposição de forma tão clara como um objetivo a ser perseguido, tendo em vista a busca por uma ordem internacional mais equitativa e estável, que beneficiaria os países do sul.

Para o Itamaraty, naquele momento, a efetividade do poder militar poderia ser comprometida por outras ameaças como, por exemplo, a pobreza e a exclusão social; desse modo, a diplomacia brasileira passou a desenvolver seu trabalho através da articulação entre defesa da paz/segurança com a promoção do desenvolvimento econômico, uma vez reconhecida que a estabilidade e segurança não podem ser alcançadas em locais em que imperem miséria e atraso. Isso significou para o Brasil, a adesão a regimes multilaterais e de não proliferação de armamentos, por exemplo, inclusive com a descaracterização do perfil militar nos projetos de desenvolvimento em que passou a se envolver, apostando no direito e nas instituições internacionais na busca de benefícios de poder para o país, conciliando valores, interesses e resultados. Assim, o desenvolvimento tornou-se importante objetivo a ser perseguido e a cooperação técnica, 
por sua vez, tornou-se o instrumento, por excelência, da PEB na busca pela consecução desse objetivo. Atrelada aos preceitos da comunidade internacional em relação às missões de paz, é no Haiti que se localiza a mais importante contribuição brasileira, a MINUSTAH (Brigagão, 2012; Rodrigues, 2012).

O caso da MINUSTAH é emblemático em pelo menos três aspectos: 1) trata-se de um dos maiores contingentes brasileiro já deslocado sob o comando da ONU, sendo o país o principal contribuinte de tropas; 2) o contingente é integrado em sua maioria por forças sul-americanas $^{24}$, um caso até então inédito para a ONU; e 3) é a primeira vez que o comando militar de uma operação dessa natureza foi entregue ao Brasil (Hermann, 2011).

A tradição anti-intervencionista na qual a diplomacia brasileira sempre esteve pautada, fez com que o Brasil, em 1994, se abstivesse em quatro das sete votações relacionadas à intervenção no Haiti. A justificativa era de que situações de crise de governabilidade não eram razões plausíveis para que fossem realizadas intervenções militares. No entanto, dez anos depois, o princípio da não-indiferença, como visto anteriormente, surgiria como uma justificativa sólida o suficiente para o governo brasileiro legitimar sua participação na Missão - não sem enfrentar grande oposição -, ganhando força a ideia de que as novas responsabilidades que o país havia assumido no Haiti pretendiam evitar outras presenças nocivas à população local (Hirst, 2012).

A decisão do governo teria sido baseada na justificativa de obstruir a crise político-social pela qual o Haiti passava. Em 29 de fevereiro de 2004, o então presidente, Jean-Bertrand Aristide, renunciou ao cargo e deixou o país, originando a revolta de grupos internos e intensificando a insegurança, situação que contribuiu para ampliar as condições de vulnerabilidade de parcelas da sociedade civil, já vitimadas por alarmantes níveis de pobreza. Neste contexto, é criada pelo Conselho de Segurança da ONU, a Força

\footnotetext{
24 "A MINUSTAH contaria com mais de 6.700 militares e cerca de 1.600 policiais e seu caráter internacional seria configurado pela origem de seus componentes. Assim, os países que contribuiriam com pessoal militar seriam, além do Brasil, a Argentina, Bolívia, Canadá, Chile, Croácia, Equador, França, Filipinas, Guatemala, Jordânia, Marrocos, Nepal, Paquistão, Paraguai, Peru, Sri Lanka, Estados Unidos e Uruguai. O contingente policial seria formado por Argentina, Benin, Bósnia- Herzegovina, Brasil, Burkina Faso, Camarões, Canadá, Chade, Chile, China, Colômbia, Egito, El Salvador, Espanha, Estados Unidos, Filipinas, França, Granada, Guiné, Iemem, Jordânia, Madagascar, Mali, Ilhas Maurício, Nepal, Niger, Nigéria, Paquistão, Romênia, Rússia, Senegal, Serra Leoa, Togo, Turquia, Uruguai, Vanuatu e Zâmbia" (Valler Filho, 2007; p. 170).
} 
Multinacional Interina, sendo no mesmo ano substituída pela MINUSTAH (Valer Filho, 2007).

O mandato da Missão foi formulado em três seções correspondentes a três objetivos: 1) proporcionar segurança e estabilidade através da restauração e manutenção do Estado de Direito (Rule of Law), da reestruturação e reforma da Polícia Nacional Haitiana (PNH) e de um programa de desarmamento, com ações baseadas no Capítulo VII da Carta ONU; 2) garantir o restabelecimento do sistema político, desfeito mediante a renúncia do presidente Aristides; 3) promover e proteger os direitos humanos, sobretudo de mulheres e crianças através do apoio às autoridades e instituições do país em conjunto com o Alto Comissariado das Nações Unidas para os Direitos Humanos (Cavalcante, 2010).

A partir dessas orientações, ainda em 2004, na Conferência de Doadores para o Haiti, realizada em Washington, o Brasil reafirmou o compromisso de realizar, em curto prazo, uma missão de avaliação para definir possíveis projetos de cooperação, aliando a busca pela garantia de direitos civis e políticos, sob a chave da intervenção militar, e direitos econômicos e sociais, através da cooperação técnica (Valer Filho, 2007).

Para Hirst (2012), a decisão de integrar a MINUSTAH proporcionou ao Brasil a possibilidade de combinar ações diplomáticas, militares e de cooperação horizontal; o Haiti tornou-se o principal destino dos programas de cooperação para o desenvolvimento, sobretudo após o terremoto de 2010 ,

"Logo, o trabalho realizado de assistência ao desenvolvimento neste país adquiriu um valor emblemático: tornou-se o mais representativo no comprometimento de recursos e tempo, de diversidade de envolvimento de agências burocráticas e de formatos inovadores de associação com terceiros parceiros. Do ponto de vista conceitual, este esforço passou a ser guiado pela noção de uma cooperação com sentido sustentável e estrutural" (Hirst, 2012; p. 21).

Em comunicado conjunto, assinado em Porto Príncipe, pelo presidente Lula e o presidente haitiano Boniface Alexandre, em 18 de agosto de 2004, Lula confirmou o envio da missão brasileira de cooperação técnica, coordenada pela $\mathrm{ABC}$ para o dia 23 de agosto, integrada por mais de vinte especialistas das seguintes áreas: combate à fome e à pobreza; saúde, segurança alimentar, agricultura, agroindústria, justiça, defesa civil, transportes, infra- 
estrutura e administração aeroportuárias, administração territorial e meio ambiente. De acordo com o documento: "Os dois presidentes reiteram sua vontade comum no sentido de implementar imediatamente os projetos de cooperação resultantes dos trabalhos da missão de cooperação técnica” (Comunicado Conjunto Brasil e Haiti, 2004).

\subsection{Brasil no Haiti: Uma análise quantitativa e qualitativa}

A entrada e prioridade conferida à questão haitiana na agenda de política externa do governo Lula foi resultado de dois eventos que marcaram de forma crucial a expansão e o fortalecimento da atenção conferida aquele país. Por um lado, a já mencionada participação do Brasil na MINUSTAH em 2004, e por outro o terremoto que assolou o país no dia 12 de janeiro de 2010.

De acordo com dados da ONU, o terremoto de 7.2 de magnitude na escala Richter durou 35 segundo mas foi o suficiente para destruir praticamente todo o país, deixando mais de 200 mil mortos, além de aproximadamente 300 mil prédios em ruínas, dentre os quais constavam aqueles que abrigavam as instituições de governo e própria sede das Nações Unidas $^{25}$. Com um histórico já marcado pela diáspora - em que se estima que mais de 2 milhões de haitianos tenham abandonado o país em virtude de questões políticas, desemprego e falta de melhores condições de vida -, o terremoto só fez agravar este cenário, levando milhares de cidadãos a buscarem um recomeço em outros países, sobretudo no Brasil.

Assim, os anos de 2004 e 2010 constituem-se como dois marcos que revelam diferenças substanciais no tipo de cooperação prestada pelo Brasil no Haiti, sobretudo no que diz respeito às áreas contempladas pelos projetos executados. Se entre o período compreendido pela entrada na MINUSTAH até o terremoto, os projetos concentravamse prioritariamente nas áreas relacionadas às políticas de eliminação da fome e pobreza, a partir de 2010, focaram-se na reconstrução do país, reforçando a prática humanitária no que tange à saúde e à doação de alimentos. Na prática, estas alterações resultaram em um

\footnotetext{
${ }^{25}$ Disponível em https://nacoesunidas.org/exclusivo-cinco-anos-depois-do-terremoto-que-destruiu-o-haitionu-continua-apoiando-reconstrucao-do-pais/ (Acesso em 25 de junho de 2016).
} 
processo de adaptação da CTPD, a fim de que esta pudesse oferecer o suporte necessário para o estado emergencial pós-terremoto; em relação ao aparato institucional brasileiro, novos ministérios e agências foram chamadas a prestar cooperação com o Haiti.

Uma questão que não foi levantada anteriormente quando demonstrou-se o aumento no envio de Acordos de Cooperação e Ajustes Complementares pelo ex-presidente Lula ao Congresso no período que compreendeu os seus dois mandatos, e que será discutida aqui, diz respeito aos mecanismos jurídico-políticos que regem estes atos internacionais. A Constituição Federal de 1988, dispensa ao Presidente da República, competência exclusiva para celebrar Tratados, Convenções e Atos Internacionais, que estão por sua vez, sujeitos ao referendo do Congresso Nacional, de modo que cabe exclusivamente a este último resolver definitivamente sobre essa matéria quando estes instrumentos possam acarretar encargos ou compromissos gravosos ao patrimônio nacional (Artigo 84, inciso VIII e Artigo 48, inciso I). A cooperação brasileira está amparada pela legislação que rege os Atos Internacionais, dividindo-se em dois grupos: i) aporte jurídico e ii) aporte político (MRE, 2008; ABC, 2013).

No grupo 1 encontram-se os Acordos-Quadro ou Acordos-Básico e os Ajustes Complementares. O primeiro, também conhecido como "guarda-chuva" estabelece o marco geral de uma cooperação, seja de natureza política, econômica, comercial, cultural, científica ou técnica. Como qualquer ato internacional, deve ser ratificado pelo Congresso, formalizando as relações de cooperação entre o governo brasileiro e o governo do país parceiro, ou ainda entre o primeiro e uma organização internacional, a exemplo do que ocorre nos programas de cooperação técnica trilateral com organismos da ONU. Este é o tipo de acordo responsável por definir o arcabouço institucional que passará a orientar a execução da cooperação e deve ser complementado por instrumentos posteriores, como os Ajustes Complementares ou os Programas Executivos, que implementam seus dispositivos no plano concreto.

O Ajuste Complementar, por sua vez, é o ato que normatiza a execução do AcordoQuadro, detalhando as áreas de entendimento específicas e as respectivas formas de implementação. Tendo em vista sua evolução para um caráter cada vez mais técnicoadministrativo, e menos jurídico-formal, os Ajustes Complementares tendem a cada vez mais assumir a forma de Programas Executivos de implementação. Eles incluem artigos 
que versam sobre os objetivos do projeto, orçamento e gestão, bem como a operacionalização do mesmo, além de dispositivos específicos que tratam das obrigações das partes e da prestação de contas. Esses dois tipos de atos dispensam a aprovação pelo Congresso.

Através do levantamento do número de Acordos de Cooperação e de Ajustes Complementares, é possível perceber duas grandes ondas de ampliação do número de projetos, sendo a primeira em 2006, dois anos após a chegada das tropas militares brasileiras no Haiti, e a segunda, em 2010, logo após o terremoto. Em números, o pósterremoto obteve ainda maior atenção por parte do governo, totalizando a assinatura de 15 Ajustes Complementares em diferentes áreas, tais como agricultura, educação, saúde, defesa civil, cultura e esporte (Anexo 1).

\begin{tabular}{|c|c|c|}
\hline \multicolumn{2}{|c|}{} \\
Tabela 3. Acordos e Ajustes Complementares de Cooperação Técnica entre Brasil Haiti (2004-2010) \\
\hline Tipo de Ato & Ano & Número \\
\hline Acordo Básico & $1982^{*}$ & 1 \\
\hline Ajustes Complementares & 2004 & 6 \\
\hline Ajustes Complementares & 2006 & 1 \\
\hline Termo de Cooperação & & 3 \\
\hline Ajustes Complementares & 2008 & 2 \\
\hline Acordo de Cooperação & & 1 \\
\hline Ajustes Complementares & 2009 & 15 \\
\hline Ajustes Complementares & 2010 & 31 \\
\hline Total & & 20 \\
\hline
\end{tabular}

Fonte: Sistema Consular Integrado - Sistema de Atos Internacionais (SCI). Disponível em: http://daimre.serpro.gov.br/ (Acesso em 04 de novembro de 2014)

* Foi mantido porque é o acordo-quadro que rege os demais Ajustes

Uma questão importante em relação aos Acordos e Ajustes Complementares no que diz respeito aos seus aspectos jurídicos é que, embora caiba exclusivamente ao presidente o poder de celebrá-los, este não assinou nenhum deles. A ABC prevê a intermediação do MRE, representando a União, para firmá-los, o que torna plausível que destes 31 Acordos e Ajustes, 11 tenham sido assinados por ministros das Relações Exteriores (Ramiro Saraiva Guerreiro em 1982, e Celso Amorim nos demais anos). Ademais, outras autoridades que exerciam funções ligadas ao MRE também assinaram 8 destes documentos (4 em 2006 por Ruy Nunes Pinto Nogueira, então Subsecretário-Geral de Cooperação e Comunidades Brasileiras no Exterior; 1 em 2010 por Antônio Patriota, 
então Secretário-Geral do Ministério das Relações Exteriores, e 3 por Igor Kipman, Embaixador Extraordinário Plenipotenciário no Haiti, referente aos anos de 2008, 2009 e 2010).

Entretanto, chama atenção o fato de que dois deles, Estudo para a Formação de Ações de Fortalecimento da Agricultura Familiar e da Segurança Alimentar e Nutricional e Construção de Cisternas para Captação e Armazenamento de Água de Chuva no Haiti tenham sido assinados pelo então ministro do Desenvolvimento Social e Combate à Fome (MDS), Patrus Ananias, no início de 2010. Embora este seja um dado muito mais simbólico que propriamente um achado de pesquisa - visto que os ministros de Estado representam a União no contexto interno, e o podem fazer externamente - ele lança luz sobre a ampliação da discricionariedade atribuída aos ministérios para também atuarem no processo de decisão em política externa, facultando a eles a definição de políticas que serão adotadas e posteriormente implementadas.

Dando continuidade à legislação que rege a CTPD, ao grupo 2, que trata do aporte político, pertencem os Memorandos de Entendimento (MdE) e Declarações Conjuntas, e os Protocolos de Intenções. Os MdE e as Declarações Conjuntas são atos redigidos de forma genérica e simplificada que demonstram a intenção entre países ou países e organizações internacionais, em estabelecer atividades de cooperação. De acordo com a ABC (2013), esse é um documento político, de modo que não acarreta obrigações de qualquer espécie e tampouco prevê o empenho de recursos, ou seja, para o governo brasileiro ele não oferece respaldo jurídico para iniciativas de cooperação, sendo assim, não requer ratificação pelo Congresso e podem entrar em vigor já na data de assinatura.

Tabela 4. Memorandos de Entendimento e Declarações Conjuntas entre Brasil e Haiti (2004-2010)

\begin{tabular}{|c|c|c|}
\hline Tipo de Ato & Ano & Número \\
\hline Comunicado Conjunto & 2004 & 1 \\
\hline Memorando de Entendimento & 2004 & 1 \\
\hline Memorando de Entendimento & 2005 & 2 \\
\hline Memorando de Entendimento & 2006 & 5 \\
\hline Memorando de Entendimento & 2007 & 11 \\
\hline Memorando de Entendimento & 2010 & 1 \\
\hline Total & & . \\
\hline
\end{tabular}

Fonte: Sistema Consular Integrado - Sistema de Atos Internacionais (SCI). Disponível em: http://daimre.serpro.gov.br/ (Acesso em 04 de novembro de 2014) 
O Memorando de Entendimento assinado em 2004 por Lula, quando da visita ao Haiti, é um documento simples, no qual o ex-presidente deixa clara a intenção do governo brasileiro em colaborar para o estabelecimento de um ambiente democrático e seguro para o país, por meio da MINUSTAH, e ao mesmo tempo reitera, conforme dito na Conferência Internacional de Doadores realizada em Washington, o envio de missões técnicas para o início da cooperação entre os dois países. Os demais documentos, ora foram assinados pelo chanceler Celso Amorim ora por Antônio Patriota, este último na condição de Secretário-Geral do Ministério das Relações Exteriores. Tal como o ocorrido com os Acordos e Ajustes Complementares, Fernando Haddad, então ministro da Educação, assinou um Memorando entre Brasil e a Organização das Nações Unidas para a Agricultura e Alimentação (FAO), para a implantação do que viria a ser o programa de merenda escolar no Haiti. Da mesma forma, José Gomes Temporão, então ministro da Saúde, assinou em 2010, o Memorando que daria início ao Programa de Fortalecimento do Sistema e dos Serviços Públicos d Saúde e Vigilância Epidemiológica no Haiti. Ademais, em sua maioria, os Memorandos foram assinados com Organizações Internacionais, como aquela supracitada, entre outras ${ }^{26}$.

Por fim, o último tipo de ato internacional, a integrar o Grupo 2, são os Protocolos de Intenções, instrumento firmado entre um órgão da Administração Pública no Brasil e uma entidade do chamado terceiro setor ou setor privado (organização não-governamental ou empresa), que registra a intenção de ambas em trabalhar conjuntamente. Sua assinatura não acarreta compromissos, nem o documento possui valor operacional ou executivo. No caso haitiano, foram assinados 5 Protocolos de Intenções entre 2006 e $2010^{27}$.

26 Banco Interamericano de Desenvolvimento (BID); Banco Internacional para Reconstrução e Desenvolvimento (BIRD); Organização Internacional do Trabalho (OIT); Programa das Nações Unidas para o Desenvolvimento (PNUD). Fonte: Sistema Consular Integrado - Sistema de Atos Internacionais (SCI). Disponível em: http://dai-mre.serpro.gov.br/ (Acesso em 04 de novembro de 2014).

${ }^{27}$ As informações a respeito da CTPD nos âmbitos jurídico e políticos encontram-se organizadas pelo MRE, no qual constam cópias digitalizadas dos documentos para consulta. O mesmo não pode ser dito em relação aos projetos, que além de não possuírem cópias disponíveis em sua totalidade - mesmo nos locais em que deveriam estar, como o próprio site da $\mathrm{ABC}$ ou dos Ministérios - possuem dados fragmentados e muitas vezes destoantes. Por exemplo, durante o período que compreendeu a pesquisa, o site da ABC passou por transformações, de modo que algumas informações outrora disponíveis já não estão mais, o que não acarretou prejuízo à pesquisa, pois o banco de dados já havia sido construído. No entanto, na tentativa de atualização de algumas informações acerca dos projetos anteriores (2004 a 2010), eles mantiveram apenas 


\section{Tabela 5. Protocolos de Intenções entre Brasil e Haiti (2004-2010)}

\begin{tabular}{|c|c|c|}
\hline Tipo de Ato & Ano & Número \\
\hline Declaração de Intenções & 2006 & 1 \\
\hline Protocolo de Intenções & 2006 & 2 \\
\hline Declaração de Intenções & 2009 & 1 \\
\hline Protocolo de Intenções & 2010 & 5 \\
\hline Total & & 1 \\
\hline
\end{tabular}

Fonte: Sistema Consular Integrado - Sistema de Atos Internacionais (SCI). Disponível em: http://daimre.serpro.gov.br/ (Acesso em 04 de novembro de 2014).

O projeto de Cooperação Técnica, por sua vez, constitui-se em uma ação planejada, com prazo definido e com o objetivo de organizar as ações que serão realizadas no país com o qual se pretende cooperar, delineando as metas atingidas, os mecanismos de execução administrativo-financeira e de coordenação conjunta entre os órgãos e agências dos dois governos participantes, além de um orçamento detalhado, e de um plano de trabalho.

Foram identificados no site da ABC até 2013, um total de 50 projetos de CTPD entre Brasil e Haiti nas mais diversas áreas, com ênfase em agricultura, segurança e saúde. Dada a imprecisão de algumas informações disponíveis, não é possível obter a data exata de início de 3 deles. Assim, foram considerados aqueles que apresentam esta informação, de tal modo que entre 2005 e 2010 foram contabilizados 43 projetos (Anexo 2). Além disso, é importante salientar que foram realizadas nesse mesmo intervalo temporal - à exceção de uma que ocorreu ainda em 2004 - 52 missões de avaliação e participação em eventos-chave que fundamentaram subsequentes projetos de cooperação (Anexo 4).

aqueles que estão em execução atualmente, conferindo uma quase exclusividade aos projetos da área da saúde. Além disso, o Ministério da Saúde, conforme será visto no capítulo seguinte, tomou a iniciativa de organizar uma ferramenta online, o Sistema de Acompanhamento de Projetos e Atividades de Cooperação (Siscoop), com vistas a disponibilizar publicamente as atividades de cooperação internacional do Ministério. Criado em 2009, até hoje as informações contidas no sistema são de pequena monta e incompletas, apesar da iniciativa ser considerada positiva, e de ainda oferecer um elegante layout. O que se quer aqui pontuar é a dificuldade de acesso às informações sobre a CTPD, que ainda constitui-se em um forte entrave à realização de futuros trabalhos na área, exigindo do pesquisador, ou a espera por informações oriundas do projeto de Acesso à Informação, ou o deslocamento até Brasília para a realização de pesquisas. De qualquer modo, buscou-se a maior rigidez possível no trato com as informações sobre os projetos de cooperação técnica com o Haiti, a fim de se chegar a um resultado ótimo para a demonstração dos dados, tanto os de natureza quantitativa, quanto qualitativa. 
Gráfico 3. Número de projetos de CTPD entre Brasil e

Haiti (2005 - 2010)

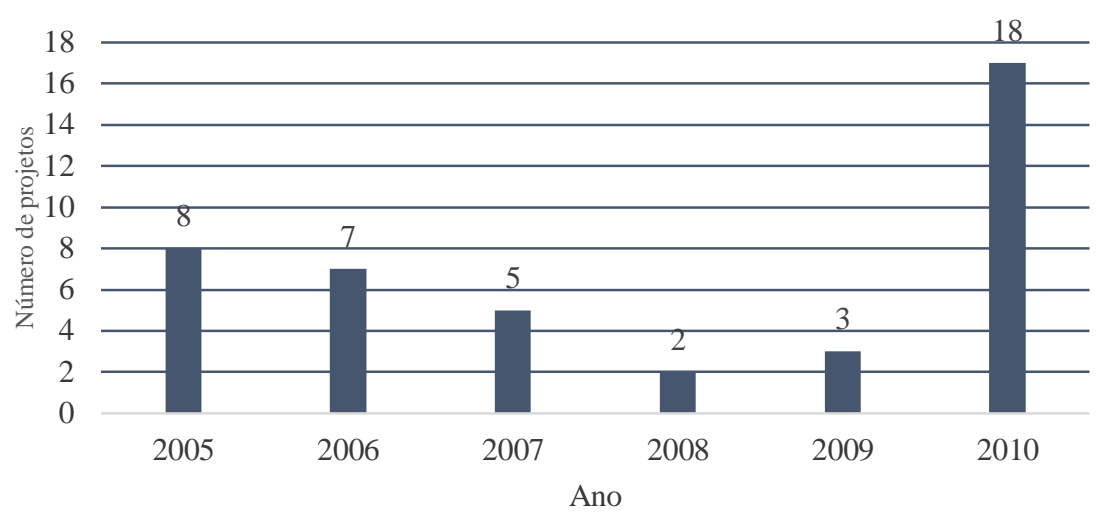

Fonte: ABC - http://www.abc.gov.br/

(Acesso em 10 de outubro de 2014)

Se entre 2005 e 2009 pode ser observado um movimento de queda na implementação de projetos, em 2010 o número volta a subir, muito em função do terremoto, momento que propiciou um crescimento exponencial do número de Ajustes Complementares, conforme demonstrado na tabela 2, o que, por sua vez, ensejou consequente aumento no volume de cooperação técnica prestada ao país.

Esta informação, no entanto, apenas pode ser explicada a partir de uma análise mais qualificada dos dados no que tange à natureza destes projetos. Entre 2005 e 2009, momento inicial da cooperação entre os dois países, destacou-se as áreas de agricultura e segurança alimentar ${ }^{28}$, tendo sido provisoriamente interrompidas em função do terremoto de janeiro de 2010. O período compreendido entre a conclusão da elaboração do documento de projeto e a primeira visita para viabilizar o início das ações no campo de agricultura foi de aproximadamente 07 meses, (março a outubro), e deste até o terremoto passaram-se mais 03 meses, ou seja, de outubro a janeiro, todos os esforços que já haviam sido reunidos para a elaboração do projeto e futura consecução foram perdidos, dado que o terremoto alterou profundamente as condições do Haiti, não apenas no setor agrícola, mas em sua sustentação política e institucional, fundamentais para a existência da CTPD. Desde então, não houve novas iniciativas neste setor.

\footnotetext{
${ }^{28}$ Embora sejam diferente, optou-se por agrupar as duas áreas, já que os projetos relacionam as duas diretamente.
} 
Tomaram lugar, então, as ações da Coordenação Geral de Combate à Fome (CGFome), órgão vinculado ao Itamaraty. Em entrevista realizada com a Coordenação, foi salientado o caráter humanitário da cooperação exercida pela Coordenação atuando, sobretudo, por meio da doação de alimentos através do Programa Mundial de Alimentação (PMA), sob os auspícios da ONU, do qual o Brasil é um dos grandes doadores.

Os projetos realizados pelo CGFome vão além da cooperação humanitária, que envolve a doação de alimentos, pois eles têm projetos de agricultura, como o Programa Mundial de Alimentação, o Programa de Alimentação Escolar, que visam atender ao treinamento dos produtores locais, ambos focados na busca de estratégias para a sustentabilidade dessas ações ao longo do tempo. Através da entrevista, foi levantada a questão acerca da linha tênue que distingue, no caso específico de sua atuação, a cooperação técnica da cooperação humanitária, de modo que não é possível pela leitura dos atores - a $\mathrm{ABC}$ também já havia posicionado-se da mesma forma - distingui-las para além do campo discursivo, uma vez que na prática, é difícil estabelecer uma competência clara entre elas. Por tratarem-se de projetos pontuais, eles estão fora das atribuições da $\mathrm{ABC}$, sendo definidos e implementados diretamente pela própria Coordenação, não estando, portanto, contemplados entre os dados aqui expostos.

\section{Gráfico 4. Projetos de CTPD entre Brasil e Haiti por Área (2005- 2010)}

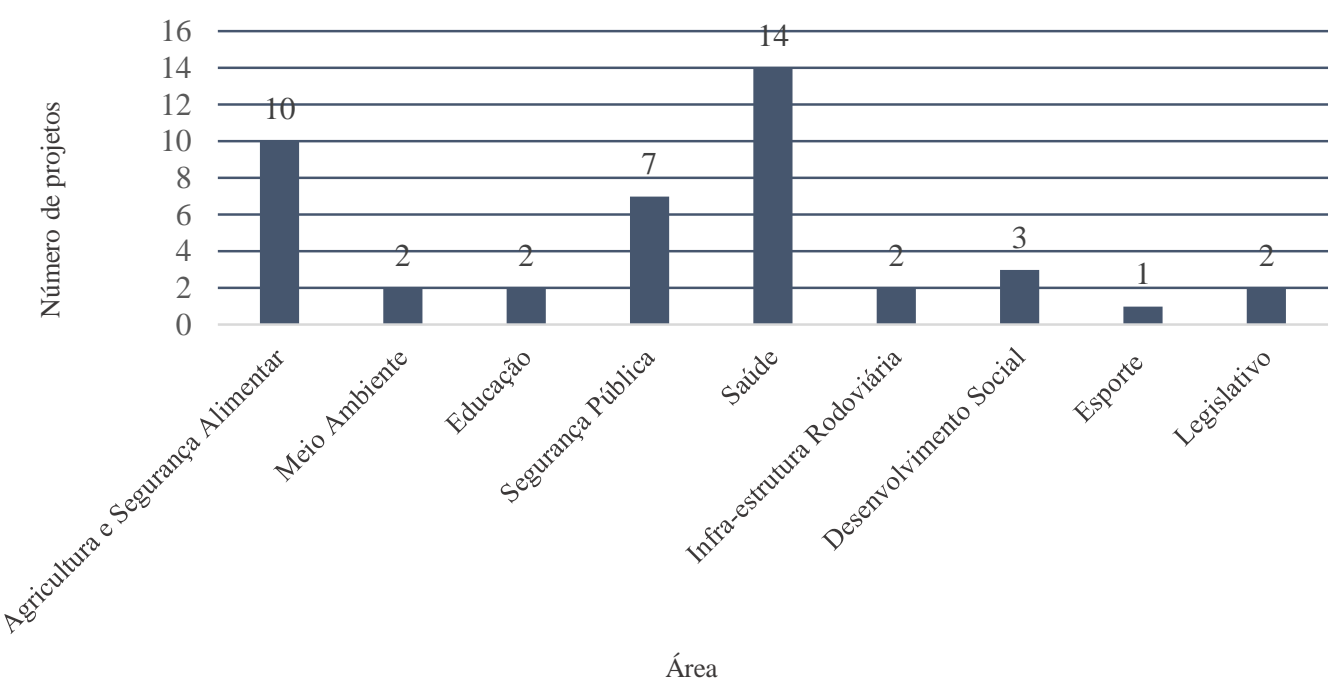

Fonte: ABC - http://www.abc.gov.br/ (Acesso em 10 de outubro de 2014 
No âmbito de projetos, os esforços pós-terremoto foram principalmente realizados pelo Ministério da Saúde, dos quatorze pertencentes à pasta, dez foram implementados após o desastre ainda em 2010. Em entrevista realizada com a ABC, constatou-se que foram realizados treinamentos de médio prazo para formação de agentes comunitários de saúde, agentes de saúde ambiental e outros. Para isso, foi desenvolvida uma rede de parcerias que incluiu a Universidade Federal de Santa Catarina (UFSC), a Universidade Federal do Rio Grande do Sul (UFRGS) e a Fundação Oswaldo Cruz (Fiocruz), além de outros parceiros que apoiaram os projetos, como OPAS, o PNUD, e o Escritório das Nações Unidas para Serviços de Projetos, da sigla em inglês, UNOPS. Esta questão, entretanto, será tratada no próximo capítulo quando a atuação do MS no Haiti será posta em tela.

Outrossim, o que estas informações preliminares demonstram é o envolvimento de diferentes atores trabalhando em cooperação para a consecução dos projetos, em consonância com o que foi exposto pela bibliografia no capítulo anterior. Esta observação no entanto, não se esgota por si só, de modo que se é pretendido qualificar as relações Brasil-Haiti, no sentido de problematizar a atuação dos atores envolvidos no que concerne às suas competências e práticas, é necessário um aprofundamento que permita, antes que sistematizar informações, trazer para o debate questões que possibilitem a ampliação das pesquisas sobre o tema.

\subsection{Os atores da CTPD}

Em entrevista com a $\mathrm{ABC}$ foi possível levantar informações que ajudaram, em um plano específico, identificar elementos do funcionamento da CTPD no que diz respeito aos atores envolvidos e o caminho percorrido pelos projetos, dadas as particularidades de atuação dos órgãos do governo haitiano; e em um plano macro, problematizar alguns pontos da relação entre os dois países com questões que são alvo da presente pesquisa.

Utilizando o esquema proposto por Milani (2014) apresentado no capítulo anterior, é possível observar dois grupos de atores envolvidos na política de CTPD entre Brasil e Haiti, caracterizando os governamentais e os não-governamentais. No primeiro grupo figuram as ONGs e o setor privado, ainda que, segundo a $\mathrm{ABC}$, a CTPD prestada pelo governo brasileiro, seja no Haiti ou demais países com os quais mantém este tipo de 
cooperação seja fundamental e exclusivamente desenvolvida por atores governamentais. Entretanto, existem algumas ressalvas a serem feitas em relação a este ponto e que justificam o fato de estarem presentes na discussão.

Consta tanto no que foi relatado, quanto na listagem de Projetos no site da $\mathrm{ABC}$, parcerias realizadas com dois órgãos não governamentais para a implantação de projetos brasileiros no Haiti, a saber, a Pastoral da Criança ${ }^{29}$ no projeto Apoio às Inciativas de Proteção da Criança no Haiti, em parceria com o Ministério da Saúde que contou com duas fases no ano de 2010, e que teve como objetivo "possibilitar aos técnicos da Pastoral da Criança a prospecção e elaboração de projeto de cooperação que contemple iniciativas de proteção à infância e à família no Haiti” (ABC, 2013); e a Olé Brasil, escola de futebol localizada no interior do estado de São Paulo, com o projeto Inclusão social por meio da prática esportiva, no qual jovens haitianos vieram ao Brasil estagiar por um ano na instituição e posteriormente retornaram ao seu país. Além destas, tem-se a Articulação Semiárido Brasileiro (ASA), que trabalhou junto com Universidade Federal Rural do Rio de Janeiro (UFRRJ) no projeto Construção de Cisternas para Captação $e$ armazenamento de água de chuva no Haiti. Excetuando estes três casos específicos, há ainda a atuação de ONGs brasileiras, como é o caso da Viva Rio, que em 2004 foi convidada pela ONU a desenvolver projetos no país, em diferentes áreas como educação, esporte e arte, mas neste caso, de forma autônoma e sem vínculos com a $\mathrm{ABC}$.

No segundo grupo, formado por órgãos governamentais, figuram os ministérios e secretarias, agências públicas, universidades e a Presidência da República. Entre os primeiros, foram chamados a cooperar com o empreendimento da CTPD no Haiti: Ministério do Desenvolvimento Social e Combate à Fome (MDS); Ministério da Saúde (MS); Ministério do Trabalho e Emprego (MTE); Ministério do Desenvolvimento Agrário (MDA); Ministério da Educação (MEC); Ministério da Integração (MI);

\footnotetext{
${ }^{29} \mathrm{O}$ escritório dedicado ao desenvolvimento técnico do projeto que reúne o governo brasileiro e o PNUD em prol da recuperação do sistema de saúde do Haiti receberá o nome Zilda Arns, em homenagem à médica e sanitarista brasileira que fundou a Pastoral da Criança e foi uma das mais de 200 mil vítimas do terremoto que atingiu o país caribenho em janeiro de 2010. (ver www.pastoraldacrianca.org, acesso em 11 de julho de 2016).
} 
Ministério do Turismo (MT); Secretaria de Direitos Humanos da Presidência da República (SDH/PR); Secretaria Especial de Políticas para as Mulheres (SEPM/PR); Conselho Nacional de Justiça (CNJ).

Dentre as Agências Públicas têm-se Empresa Brasileira de Pesquisa Agropecuária (Embrapa), Companhia de Desenvolvimento do Vales do São Francisco e do Parnaíba (Codevasf); Sociedade Beneficente Israelita Brasileira Hospital Albert Einstein (SBIBHAE); Instituto Fernandes Figueira - Fiocruz (IFF); Serviço Nacional de Aprendizagem Comercial (SENAC); Instituto Brasileiro de Geografia e Estatística (IBGE); Companhia Nacional de Abastecimento (Conab); Departamento da Polícia Federal (DPF/MJ); Hospital Sírio Libanês - Instituto de Ensino e Pesquisa (HSL); Empresa Brasileira de Infraestrutura Aeroportuária (Infraero); Serviço Federal de Processamento de Dados (SERPRO); Empresa de Assistência Técnica e Extensão Rural do Distrito Federal (Emater - DF) e Serviço Nacional de Aprendizagem Comercial (SENAC).

As universidades parceiras foram: Universidade do Estado de São Paulo, Faculdade de Ciências Agronômicas - USP, Universidade Federal Rural do Rio de Janeiro (UFRRJ); Universidade Federal do Rio Grande do Sul (UFRGS) e Universidade Federal de Santa Catarina (UFSC) e Universidade Federal de Santa Maria (UFSM).

Por fim, embora este seja o principal ator no que diz respeito à formação da agenda e de prioridades da política de cooperação, a atuação do Presidente, na prática, parece não interferir diretamente na consecução de projetos, exceto em casos particulares. É possível observar sua atuação quando de reuniões entre os chefes de Estado dos dois países envolvidos, em que determinada demanda local entra na agenda de discussão e é então solicitado diretamente ao presidente brasileiro o desenvolvimento de algum projeto de CTPD naquela área. Ou então, quando algum projeto que já está em tramitação em determinada instância do governo brasileiro surge nas reuniões e o presidente reitera que tal projeto é importante e passa esse informe à Casa Civil que se encarrega de repassar à $\mathrm{ABC}$, que por sua vez entra em contato com as instituições envolvidas, seja para acelerar o processo, seja para iniciar os estudos para ver a viabilidade de tal demanda. 
O que deve ser ressaltado é que durante muito tempo Lula foi atuante na cooperação com o Haiti, fosse em decorrência da MINUSTAH ou do terremoto. O então presidente participou ativamente de reuniões com os ministros haitianos e acompanhou de perto os projetos de seus ministérios naquele país. Isso corrobora as teorias que privilegiam a atuação do presidente frente à política em questão, para a sua entrada no agenda-setting. Seu papel neste processo foi o de garantir às autoridades haitianas que o Brasil estava comprometido com os problemas do país caribenho e que buscaria soluções para encaminhar as dificuldades locais. Por outro lado, seus ministérios possuíam suas agendas internacionais próprias, e se viram cooptadas a direcionar esforços para o Haiti, que nunca havia sido uma prioridade para o governo brasileiro.

Lula sofreu severas críticas no Brasil, de todas as esferas políticas e sociais, ao enviar um grande contingente de tropas para a MINUSTAH e investir recursos de seus ministérios no Haiti, pois era um jogo de soma zero, dado que a possibilidade de retorno dos investimentos, tanto militares, quanto sociais, era nula para o país. Não obstante, a mobilização ocorreu e o Ministério da Agricultura, por exemplo, foi um dos mais atuantes, no escopo da CT, empunhando a bandeira da erradicação da Fome, baluarte do governo petista, elevando ainda o reconhecimento de agências de pesquisa brasileiras, como a Embrapa. Sem dúvida que isto serviria aos interesses do país como um todo, e aos interesses pessoais do próprio presidente, conforme será visto no capítulo seguinte. No entanto, ao tratar-se estes ministérios como definidores de agendas, levando em consideração aspectos importantes citados anteriormente, como sua reputação e network, havia um interesse particular de cada um deles em internacionalizar suas próprias políticas, garantindo com isso, não só a participação de diferentes grupos de interesse nas políticas de CTPD que ocorriam concomitantemente em outros países da América do Sul, ou Índia e África que, diferentemente do Haiti, não possuíam este caráter mais humanitário, sendo portanto, passíveis de retorno para os negócios brasileiros; mas também a possibilidade de estreitar relações com agências internacionais, beneficiando a si próprios, como ocorreu entre a Organização Pan-Americana de Saúde (OPAS), braço da Organização Mundial da Saúde (OMS).

Longe de julgar estes interesses, ou seu papel como maximizadores de orçamento questão da qual não será tratada -, isso exemplifica claramente como a mobilização brasileira em prol do Haiti - embora houvesse, haja e sempre há de haver críticas, 
sobretudo de partidos e demais grupos de oposição - garantia ganhos mútuos, atendendo às agendas presidencial e ministeriais. Sem a participação de ambos, não haveria cooperação naquele país, mas é importante mais uma vez ressaltar a importância do presidente na definição desta agenda. Não é possível transportar este mesmo conjunto de interesses e contexto para outros países, pois os interesses brasileiros, na África, por exemplo, se não completamente, são muito diferentes dos que possui com o Haiti, não apenas em nível governamental, mas também entre grandes empresas e outros setores da sociedade civil. Assim, quando se aponta a importância de Lula na política de CTPD, em seus dois mandatos, ela diz respeito ao Haiti, o que não quer dizer, por outro lado, que o quadro coloque-se de maneira muito diversa em outros lugares, mas aqui, infelizmente, esta discussão não tem espaço para se desenvolver.

\subsection{Ciclo de Gestão das Iniciativas de CTPD}

A entrevista com a $\mathrm{ABC}$ possibilitou a criação de um ciclo inicial básico, que diz respeito à solicitação de cooperação entre Brasil e Haiti, e pode ser esquematizado da seguinte forma:

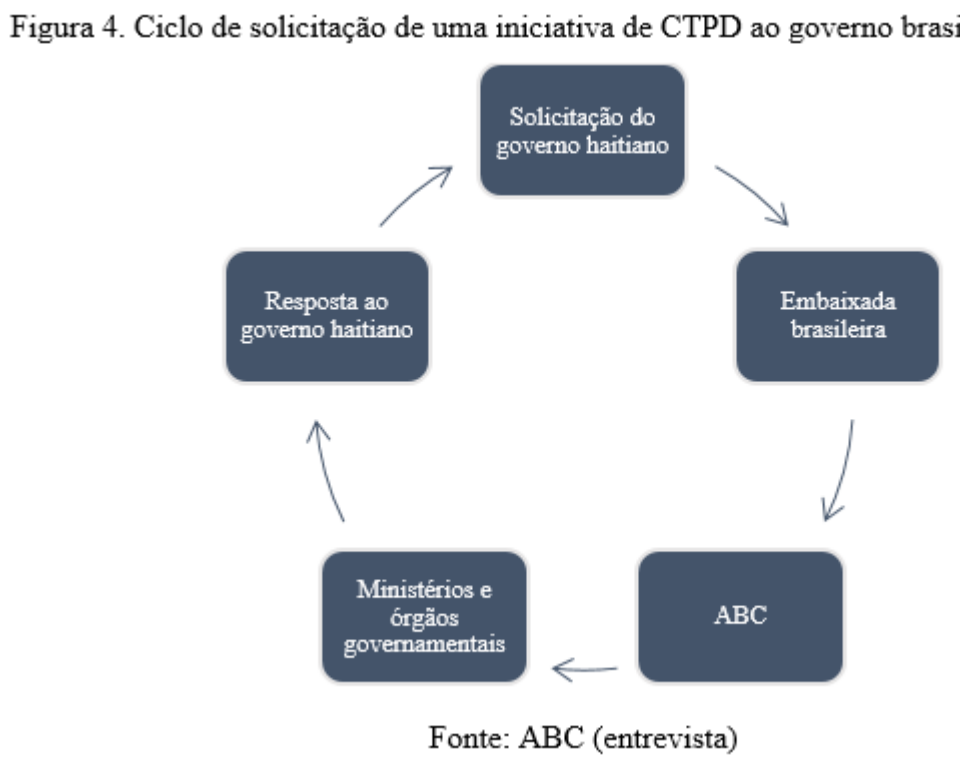

No entanto, nem sempre esta ordem é obedecida. Os ministérios e órgãos governamentais brasileiros possuem autonomia para solicitar o desenvolvimento de projetos, de modo que 
um exemplo pode demonstrar como isso desenvolve-se na prática. Ocorreu uma demanda por parte do governo haitiano dirigida ao ministério do Turismo brasileiro, solicitando treinamento e formação profissional na área de hotelaria e turismo. O pedido foi encaminhando pela embaixada à $\mathrm{ABC}$ - a quem coube o papel de captar os parceiros que melhor atendessem às exigências do projeto. Cumprida esta etapa, foi feita uma missão de prospecção pelo parceiro brasileiro no Haiti em que a embaixada local responsabilizou-se por montar uma agenda de reuniões com áreas e autoridades envolvidas para que os técnicos brasileiros pudessem, a partir do reconhecimento do contexto local, elaborar um plano de cooperação, que poderia consolidar-se em uma atividade isolada ou em uma proposta de projeto.

No entanto, após este ciclo "natural" ter sido completo, e desenvolvido parte do projeto pelo ministério do Turismo que envolvia o treinamento de técnicos na área de sanidade de alimentos, o SENAC observou que seria necessário também treinar técnicos na área de qualidade de água, partindo dele, então, a proposta. Neste caso, a solicitação foi enviada à $\mathrm{ABC}$, que por sua vez encaminhou à embaixada até que chegasse ao governo haitiano. Pode-se depreender disso uma questão importante: existe uma relativa autonomia dos atores envolvidos na CTPD para a proposição de projetos, ou seja, qualquer ator governamental pode solicitar sua aprovação. É salutar ainda que quando o ciclo é operado da maneira como foi esquematizado, embora os atores brasileiros sejam captados pela $\mathrm{ABC}$ para atuar nos projetos de CTPD, nem sempre eles estão aptos a aceitar, ou seja, eles possuem a prerrogativa de negar a participação em determinado projeto, desde que justificada a recusa, seja por falta de recursos humanos e financeiros ou mesmo pela falta de disponibilidade de uma área específica para atender àquela demanda.

Outro ponto importante da CTPD com o Haiti é a falta de um ator central local no país caribenho, como o ministério das Relações Exteriores brasileiro, que centralize, ordene e repasse as demandas, de modo que, Ministérios e organizações do governo haitiano, através de autoridades locais, muitas vezes o primeiro ministro, entram em contato diretamente com o embaixador brasileiro, ou muitas vezes, o próprio ministério haitiano, interessado em algum projeto de cooperação, manda um ofício direto para a embaixada brasileira que repassa a solicitação à $\mathrm{ABC}$. 
Muito embora possuam particularidades jurídicas e políticas, os atos internacionais e os projetos desenvolvidos posteriormente obedecem às mesmas fases da política pública apresentadas no capítulo anterior -, exceto pelo fato de que dispensam a aprovação do Congresso Nacional; tem-se, portanto, em comparação às demais políticas públicas duas principais diferenças.

A primeira é que o ato internacional antecede o projeto a ser desenvolvido, de modo que a especificação de métodos a serem empregados, objetivos, recursos humanos e financeiros e demais itens que constam em qualquer política pública levada à apreciação do Congresso são definidos a posteriori, e dependem da modalidade da cooperação que será realizada, se i) trilateral entre países em desenvolvimento; ii) trilateral com países desenvolvidos; iii) trilateral com organismos internacionais; iv) em bloco ou v) descentralizada. Além disso, ainda em relação ao marco operacional da CTPD, ela pode possuir três tipos de arranjos de execução administrativo-financeira: i) a execução pelo governo brasileiro, quando fica a cargo deste os aspectos administrativos e financeiros das iniciativas de cooperação técnica; ii) a execução paralela, que ocorre quando esses aspectos operacionais são realizados tanto pelo governo brasileiro, quanto por uma entidade parceira, como o que normalmente ocorre nos projetos trilaterais com organismos internacionais ou agências de cooperação de outros países, em que os recursos provém de ambos e cabe a cada qual de modo coordenado a execução de sua cota; iii) a execução descentralizada, quando uma outra entidade, que não o governo brasileiro, é responsável pela execução administrativo-financeira, de modo que a administração pública pode ou não ser a fonte de recursos, ainda que o governo seja o coordenador da iniciativa (ABC, 2013).

A segunda diferença, e que merece maior destaque para o entendimento da CTPD, é que ela pode ser dividida em dois momentos: o da assinatura do ato e o da assinatura do projeto, o que não significa, entretanto, que as fases sejam independentes entre si, pelo contrário, são complementares e só possuem significado jurídico e político quando vistas desta forma. Um exemplo prático, pode facilitar a compreensão.

Lula realizou uma visita oficial ao Haiti em maio de 2008 para discutir com o governo local o desenvolvimento de um Programa Estratégico de Cooperação Técnica nas Áreas 
de Segurança Alimentar e de Agricultura; nesta viagem, estava presente o ministro Patrus Ananias, do ministério do Desenvolvimento Social e Combate à Fome (MDS).

Em 25 de maio de 2008, Celso Amorim assinou em Porto Príncipe o Acordo de Cooperação entre o Governo da República Federativa do Brasil e o Governo da República do Haiti para a Elaboração e a Implementação de um Programa Estratégico de Cooperação Técnica para o Período 2008-2010 nas Áreas de Segurança Alimentar e de Agricultura. No documento foram estabelecidos sete objetivos a partir do interesse do governo brasileiro em empreender esforços para a promoção de ações de combate à fome e à pobreza na América Latina e Caribe, como forma de defender o direito à alimentação, enquanto um direito humano.

1) Envio de uma missão técnica exploratória ao Haiti na primeira quinzena de 2008 para avaliar a situação agrícola e alimentar local e identificar as tecnologias apropriadas às necessidades do país;

2) Elaboração de um Programa Estratégico de Cooperação Técnica para o período de 2008 a 2010 que deveria levar em conta os seguintes aspectos: a) avaliação de variedades vegetais; b) disponibilidade de conhecimentos e tecnologias para a melhoria dos sistemas de produção de frutas e hortaliças; c) controle de propagação de pragas; d) otimização do uso de recursos hídricos para a agricultura; e) apoio ao desenvolvimento de outras cadeias produtivas e das cooperativas rurais; f) apoio ao ensino, pesquisa, assistência técnica e extensão rural; g) formulação de políticas públicas para promoção da agricultura familiar e do desenvolvimento rural sustentável, e h) promoção da segurança alimentar e nutricional.

3) A contribuição brasileira não seria limitada aos temas citados, podendo ser estendida, após acordo entre as partes, a outras áreas que buscassem promover a segurança alimentar e o desenvolvimento sustentável da agricultura haitiana e fortalecesse as capacidades técnicas e gerenciais do governo local;

4) Posteriormente, ambos os governos deveriam indicar os interlocutores que integrariam um Comitê Executivo para a organização e realização da referida 
missão, bem como para coordenar, validar e avaliar as ações resultantes da mesma e do Programa Estratégico;

5) Ambos os governos deveriam se comprometer em mobilizar especialistas de instituições com atuação destacada nos temas indicados a fim de assegurar a implementação do Programa;

6) A cooperação técnica brasileira seria realizada por meio da transferência de conhecimentos técnicos e de sua expertise, em bases não comerciais para promover a autonomia do governo haitiano no que diz respeito ao desenvolvimento rural;

7) Ambos os governos deveriam assegurar a coordenação desse Programa Estratégico em cooperação com os organismos especializados da ONU e OEA, buscando também outros parceiros nacionais e internacionais, capazes de fornecer apoio necessário à sua elaboração e implementação.

Assinado, o documento passou a ter validade jurídica. Não obstante, no documento estão previstas as diretrizes básicas do Programa Estratégico a ser empreendido entre os anos de 2008 e 2010, não identificando parceiros, orçamentos, tipo de política a ser definida, programa a ser transferido, ou qualquer outra especificação mais detalhada sobre o método a ser empregado para atingir o objetivo almejado. Para que um projeto possa de fato existir, ele passa por três fases complementares: i) a fase analítica; ii) a fase de planejamento e iii) a fase de preparação do Documento de Projeto (ABC, 2013).

Tabela 6. Fases de elaboração dos projetos de cooperação normatizadas pela $\mathrm{ABC}$

\begin{tabular}{|c|c|c|}
\hline Fase & Especificação & Competências \\
\hline Fase analítica & $\begin{array}{l}\text { É um exercício conjunto e interativo de detalhamento, entre os potenciais } \\
\text { parceiros de cooperação, da ideia de projeto (ou de outro tipo de iniciativa, o que } \\
\text { será definido em momento oportuno). A Fase Analítica é realizada com base em } \\
\text { métodos participativos, geralmente durante uma missão de prospecção. Os } \\
\text { componentes desta fase são: } 1 \text {. O Mapeamento de Atores e Capacidades, com } \\
\text { ênfase na identificação (i) das necessidades de potenciais beneficiários e outras } \\
\text { partes interessadas na cooperação e (ii) das capacidades pré-existentes } \\
\text { disponíveis para aproveitamento pela futura iniciativa de cooperação técnica; } 2 \text {. } \\
\text { A Análise de Problemas, que consiste no levantamento dos principais problemas } \\
\text { relacionados à situação inicial insatisfatória que pauta a ação da futura iniciativa } \\
\text { de cooperação técnica, bem como das relações de causa e efeito existentes entre } \\
\text { eles; } 3 \text {. A Análise de Soluções, por meio da qual é desenhado um perfil da situação } \\
\text { que se deseja alcançar no futuro mediante a contribuição do projeto, além dos } \\
\text { meios para tanto; } 4 \text {. A Análise de Estratégias, cujo propósito é a selecão da melhor }\end{array}$ & $\begin{array}{c}\text { ABC e Instituições } \\
\text { Cooperantes }\end{array}$ \\
\hline
\end{tabular}




\begin{tabular}{|c|c|c|}
\hline & $\begin{array}{l}\text { estratégia de ação para o projeto em vista. } 5 \text {. A Análise de Riscos, com o propósito } \\
\text { de identificar os fatores que poderão afetar negativamente a iniciativa de } \\
\text { cooperação técnica, bem como possíveis medidas mitigadoras. }\end{array}$ & \\
\hline $\begin{array}{c}\text { Fase de } \\
\text { planejamento }\end{array}$ & $\begin{array}{l}\text { Trata-se da definição - fundamentada nos resultados da fase anterior e igualmente } \\
\text { realizada por meio de um processo participativo -, dos elementos técnicos e } \\
\text { operacionais básicos do futuro projeto: os objetivos e resultados esperados e as } \\
\text { metas para mensuração do seu alcance, além dos meios necessários para atingi- } \\
\text { los, e o planejamento das atividades, dos insumos e do orçamento. Esses } \\
\text { componentes serão organizados por meio de ferramentas como a estrutura lógica, } \\
\text { a matriz lógica, o cronograma de execução, o orçamento e o plano de trabalho. }\end{array}$ & $\begin{array}{c}\text { ABC e Instituições } \\
\text { Cooperantes }\end{array}$ \\
\hline $\begin{array}{l}\text { Fase de } \\
\text { preparação do } \\
\text { Documento de } \\
\quad \text { Projeto }\end{array}$ & $\begin{array}{l}\text { A terceira e última fase diz respeito à elaboração do 'Documento Preliminar de } \\
\text { Projeto', realizada com base nas informações geradas durante a fase anterior. Esta } \\
\text { fase inclui a montagem do cronograma de execução e do orçamento detalhados } \\
\text { da iniciativa - caso não tenha sido possível fazê-lo anteriormente - bem como a } \\
\text { elaboração dos demais itens do Documento de Projeto. }\end{array}$ & $\begin{array}{l}\text { Instituições } \\
\text { Cooperantes }\end{array}$ \\
\hline
\end{tabular}

Fonte: Brasil, 2013.

Em junho de 2008, o MDS participou de reunião realizada em Roma, intitulada Amigos do Haiti que contou com a presença de representantes da FAO, do Fundo Internacional de Desenvolvimento Agrícola (Fida) e do Programa Mundial de Alimentos (PMA). Nesta ocasião, Celso Amorim anunciou contribuições adicionais na área de segurança alimentar no valor de US\$ 1,4 milhões.

Em julho de 2008 chegou ao Haiti uma missão multidisciplinar organizada pela $A B C$, que contou com a participação de diferentes ministérios a fim de avaliar quais programas sociais poderiam ser implantados, ao passo que em setembro do mesmo ano, o Brasil recebeu técnicos haitianos que vieram verificar como funcionam os Programas de Aquisição de Alimentos (PAA) e o de Cisternas. Assim, em fevereiro de 2009, o secretário nacional de Segurança Alimentar e Nutricional do MDS, Crispim Moreira, esteve no Haiti para apresentar a proposta para a implementação desses dois programas, de modo que, entre março e abril de 2009, foram definidos respectivamente os projetos de Promoção de ações de fortalecimento da agricultura familiar e da segurança alimentar e nutricional no Haiti por meio do desenvolvimento de instrumentos inovadores de compras públicas de alimentos da produção local e Construção de cisternas para captação e armazenamento de água de chuva no Haiti. Esquematizando as etapas de elaboração de iniciativas de CTPD fornecidas na tabela 6, a partir do exemplo aqui utilizado - acrescentando a de entrada na agenda da PEB-, tem-se a seguinte representação gráfica: 
Figura 5. Etapas para a elaboração do projeto Construção de Cisternas Captação e Armazenamento de Água da Chuva e de Promoção de Ações de Fortalecimento da Agricultura Familiar e da Segurança

Alimentar

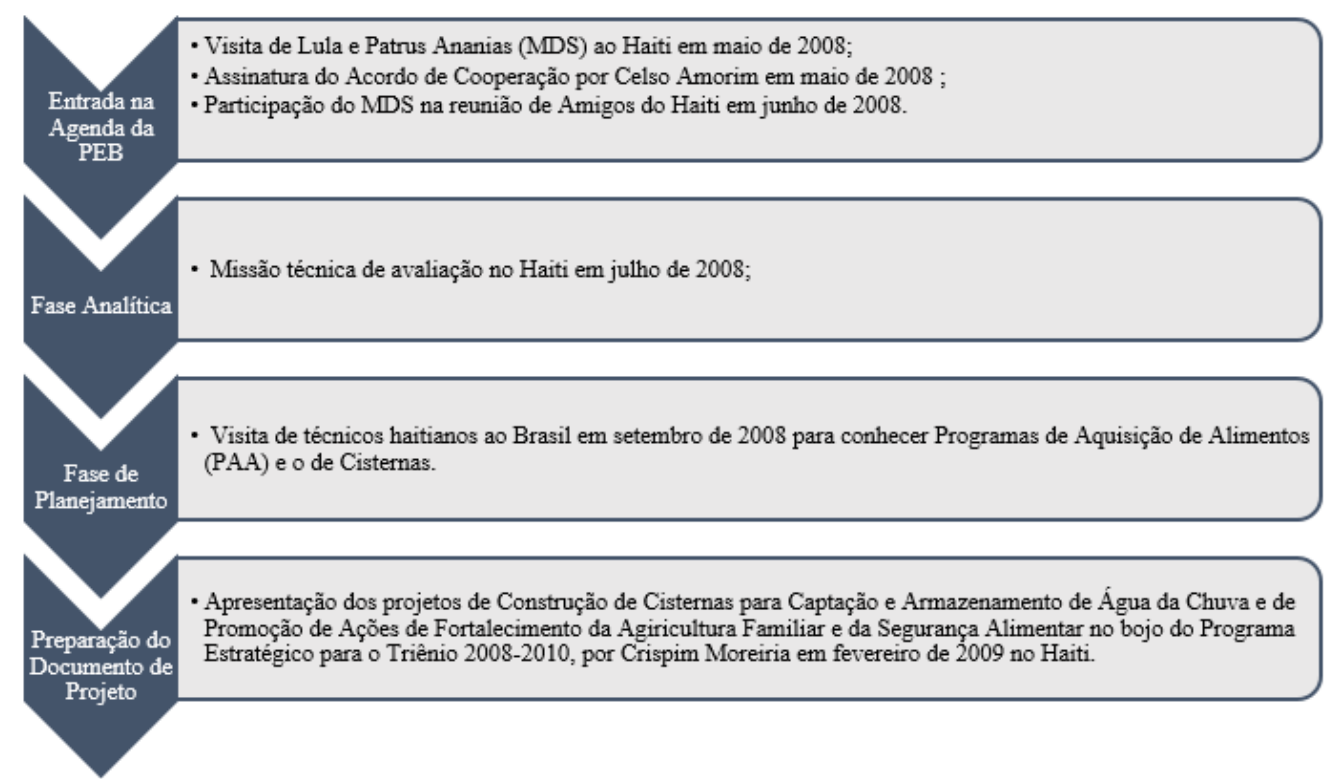

Fonte: Adaptado de ABC, 2013.

A gestão destas iniciativas, por outro lado, obedecem a fases posteriores, que tratam da formulação dos projetos, e encontra-se no interior da fase de preparação do Documento de Projetos, que são gerenciados pela $\mathrm{ABC}$, enquanto ministérios e agências governamentais são as instituições de implementação técnica. A princípio, as competências podem parecer muito bem definidas e claras, não obstante, a exemplo do que pôde ser observado na tabela 6 , no tocante às competências, quando se analisa cada uma das fases em particular é possível perceber, embora a $\mathrm{ABC}$ cumpra o papel de subsidiária dos projetos, que cabem aos demais atores grande parte da tarefa na consecução de um projeto, conforme ilustrado no quadro seguinte:

\begin{tabular}{|c|c|c|}
\hline Etapa & Descrição & Competência \\
\hline Identificação & $\begin{array}{l}\text { Recepção e a análise da solicitação de cooperação. Neste estágio, a cooperação é } \\
\text { apenas uma ideia de projeto que será analisada pelas potenciais instituições } \\
\text { cooperantes à luz dos seguintes critérios: identificação de convergência entre as } \\
\text { experiências brasileiras existentes e o setor/tema de interesse da proponente; } \\
\text { disponibilidade de recursos financeiros para a cooperação, e disponibilidade de } \\
\text { recursos técnicos e humanos para o atendimento da solicitação. }\end{array}$ & $\begin{array}{c}\mathrm{ABC} \text { e } \\
\text { Instituições } \\
\text { Cooperantes }\end{array}$ \\
\hline Prospecção & $\begin{array}{l}\text { Detalha a ideia da iniciativa e produz subsídios para a tomada de decisão conclusiva } \\
\text { a respeito da possibilidade de atendimento da solicitação de cooperação. A partir de } \\
\text { amplos diálogos entre técnicos brasileiros e do país proponente, os elementos } \\
\text { fundamentais do instrumento de cooperação técnica são delineados e analisados, } \\
\text { dentre eles os objetivos e resultados almejados, os beneficiários e demais envolvidos, } \\
\text { os mecanismos de coordenação e os insumos requeridos. }\end{array}$ & $\begin{array}{c}\mathrm{ABC} \text { e } \\
\text { Instituições } \\
\text { Cooperantes }\end{array}$ \\
\hline
\end{tabular}




\begin{tabular}{|c|c|c|}
\hline $\begin{array}{l}\text { Formulação e } \\
\text { Enquadramento }\end{array}$ & $\begin{array}{l}\text { Formulação do documento preliminar da iniciativa de cooperação técnica e } \\
\text { encaminhamento às instituições parceiras para análise. Ao final de uma sucessão de } \\
\text { contatos para refinamento da versão preliminar e mediante a aprovação das } \\
\text { contrapartes, conforme o caso, o Documento de Projeto ou de Ação Preparatória é } \\
\text { firmado. }\end{array}$ & $\begin{array}{c}\text { Instituições } \\
\text { Cooperantes e } \\
\text { ABC }\end{array}$ \\
\hline $\begin{array}{l}\text { Implementação e } \\
\text { Monitoramento }\end{array}$ & $\begin{array}{l}\text { Esta etapa abarca dois processos de gestão interligados e interdependentes. O } \\
\text { primeiro refere-se à implementação técnica e à execução administrativo-financeira } \\
\text { das atividades previstas no documento da iniciativa, a partir da mobilização dos } \\
\text { insumos e das instituições cooperantes. O segundo componente desta fase é o } \\
\text { processo de monitoramento, por meio do qual é feito o acompanhamento } \\
\text { participativo do progresso da parceria na consecução dos objetivos e resultados } \\
\text { almejados. O instrumento de cooperação (Documento de Projeto ou de Ação } \\
\text { Preparatória) pode ser adaptado e sofrer revisões. }\end{array}$ & $\begin{array}{l}\text { Instituições } \\
\text { Cooperantes }\end{array}$ \\
\hline $\begin{array}{c}\text { Avaliação e } \\
\text { Encerramento }\end{array}$ & $\begin{array}{l}\text { Após a implementação técnica da última atividade, as contrapartes procedem à } \\
\text { avaliação interna da iniciativa, o que consiste de um apanhado geral do projeto em } \\
\text { seus aspectos técnicos, gerenciais e operacionais. Quando previsto no documento da } \\
\text { iniciativa, esta última será também objeto de avaliação externa, para ser valorada } \\
\text { segundo critérios de eficácia, eficiência e sustentabilidade, dentre outros. As } \\
\text { avaliações interna e externa têm por finalidade retroalimentar a gestão das iniciativas } \\
\text { da cooperação técnica Sul-Sul, a partir da formulação de recomendações para a } \\
\text { orientação de novas parcerias similares. No caso de haver possibilidade de extensão } \\
\text { ou de seguimento, o início da nova fase de um projeto dependerá das conclusões da } \\
\text { avaliação da fase precedente. }\end{array}$ & $\begin{array}{l}\text { Instituições } \\
\text { Cooperantes }\end{array}$ \\
\hline
\end{tabular}

Fonte: Brasil, 2013.

Retomada a discussão teórica sobre a participação dos ministérios na CTPD, fica claro que além de participarem enquanto instâncias de implementação, cabem a eles também o papel de prospecção e formulação, a exemplo do que foi visto no caso da participação dos ministros Patrus Ananias, do MDS; Fernando Haddad do MEC e José Gomes Temporão do MS.

Ainda que as outras etapas listadas no quadro anterior sejam importantes para a compreensão do todo, a identificação, prospecção e formulação, são as fases nas quais se pode verificar com melhor clareza a atuação dos ministérios. O enfoque técnico que recai sobre este tipo de cooperação exige a participação ativa dos ministérios em todas as etapas de sua consecução. A maneira através da qual eles organizam-se internamente para atender às demandas da PEB nesta área é o que garante, em última instância, que a política possa ser, de fato, realizada. Eles são, portanto, elementos-chave no entendimento da CTPD, e requerem uma análise mais detida neste sentido. De acordo com o quadro, o ciclo de elaboração dos projetos, pode ser assim representado: 


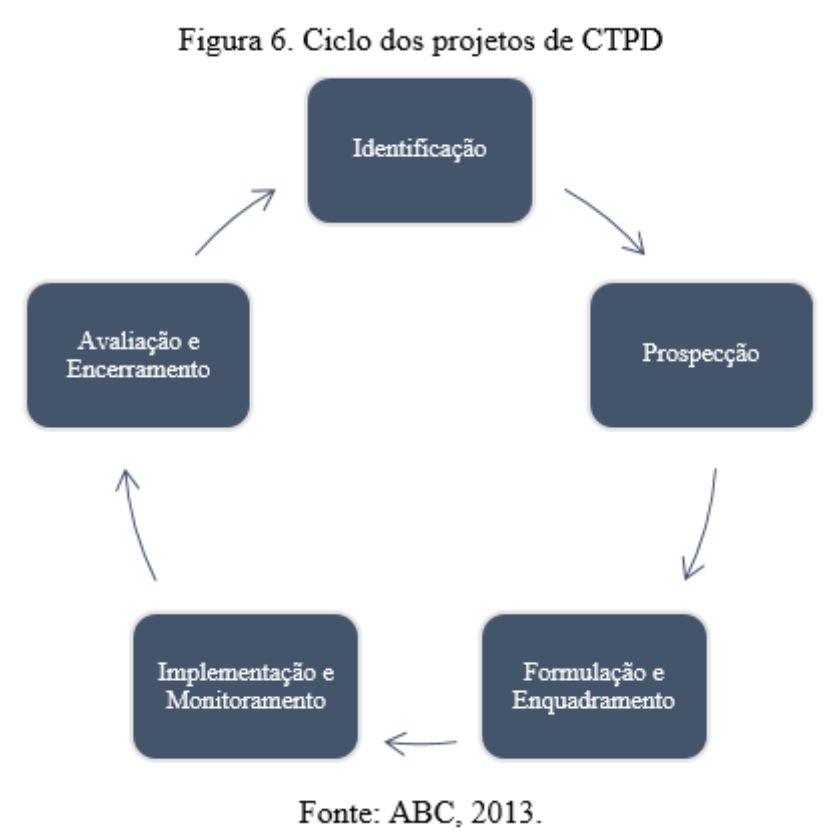

Diferentes informações podem ser obtidas através da leitura dos dois Documentos de Projetos, que totalizam em conjunto cerca de 85 páginas, o que torna inviável a abordagem detalhada de cada um deles, sobretudo pelo fato de que o objetivo principal do trabalho é analisar como este processo de formulação e implementação da CTPD ocorre no interior do Ministério da Saúde, de modo que a sistematização das etapas constantes na tabela 7 , será realizada posteriormente, quando for tratado especificamente deste ministério, pois entende-se que empregar esta tarefa aqui, exigiria um maior espaço, incompatível com o que se propõe tanto em termos de síntese explicativa, quanto de escopo analítico.

A análise deste caso específico buscou oferecer um panorama geral do processo de tomada de decisão em CTPD, privilegiando a atuação dos diferentes atores que se encontram nele envolvidos. No Haiti, como foi observado, uma gama de Ministérios responsabilizou-se pela cooperação técnica solicitada pelo presidente Lula, nas áreas consideradas prioritárias pelo governo haitiano. Não obstante, o Ministério da Saúde logrou importância destacada, pois além de ter sido o Ministério com o maior número de projetos naquele país, foi o único a atuar tanto no período anterior ao terremoto, como no posterior. Desta forma, o estudo de caso empreendido nos dois próximo capítulos, recairá sobre a pasta da saúde, primeiro para possibilitar uma compreensão mais geral de como o Ministério insere-se internacionalmente, e segundo para verificar como ele atuou - ou atua - no Haiti, levando em conta toda a discussão até aqui apresentada sobre o processo 
de delegação e horizontalização de competências presentes na política externa brasileira contemporânea.

\section{Considerações Finais}

O emprego do modelo do Ponctuated Equilibrium, valida empiricamente a hipótese de que a CSS - e consequentemente a CTPD - ganhou ampla atenção de Lula durante os seus dois mandatos (2003 - 2010). Os dados apresentados, vão de encontro à principal premissa estabelecida por Baumgartner e Jones (1993), de que o presidente é um dos principais atores no que tange à formulação do agenda-setting. Além disso, reitera a constatação de que, por isso, é muito grande a sua capacidade em alterar os rumos a serem tomados através da adoção de determinadas políticas públicas.

A CTPD, em particular, tem como bases jurídica e política os atos internacionais e os documentos de projeto, respectivamente, que em última instância, possuem três principais diferenças quando comparadas às demais políticas públicas. A primeira, é que cabe tão somente ao Executivo sua celebração; a outra é que, aprovado pelo Congresso o ato internacional que possibilita sua execução (Acordo-Quadro), ela fica dispensada de posterior consulta ao legislativo para a celebração dos demais Ajustes Complementares, que são responsáveis pela sua operacionalização. E por fim, é que este mecanismo institucional a divide em duas etapas: a jurídica (com a participação efetiva do presidente) e a política (com participação efetiva de Ministérios).

Ainda que essa afirmação seja válida, foi possível perceber que, em grande medida, o presidente não assina os atos, cabendo aos chanceleres e demais ministros esta tarefa, prática comum na qual se pode observar com muita clareza o funcionamento do mecanismo da delegação política. Aqui, a função do agente (ministérios) ultrapassa a de implementação, visto que eles participam ativamente da celebração dos atos e na formulação dos documentos de projetos, como pôde ser verificado para o caso da participação dos ministros Patrus Ananias, do MDS na cooperação técnica brasileira no Haiti. 
O enfoque no estudo de caso específico empreendido até aqui, confirma o recente processo de horizontalização de competências apontado pela literatura, em que os ministérios aparecerem adentrando a arena política e viabilizando a consecução da CTPD. Não obstante, resta ainda maior clareza de como se dá este processo, sem que ocorra o problema intrínseco à teoria do principal-agente, do uso indevido do poder discricionário conferido às burocracia. 


\section{CAPÍTULO 3. A COOPERAÇÃO TÉCNICA ENTRE PAÍSES EM DESENVOLVIMENTO: O CASO DO MINISTÉRIO DA SAÚDE}

Os ministérios da saúde dos diferentes Estados são, via de regra, responsáveis pela saúde pública em seus territórios nacionais, constituindo-se em estruturas políticoadministrativas que atendem aos interesses domésticos. Neste sentido, são carentes per se de ramificações externas que, em última instância, lhes possibilitariam atuar internacionalmente. Entretanto, conforme será demonstrado neste capítulo, o Ministério da Saúde brasileiro foi um dos principais atores na política de CTPD empreendida no Haiti no recorte temporal aqui adotado.

Ainda que, nesse contexto específico, muito tenha sido discutido sobre as relações estabelecidas entre o Brasil e a América do Sul e/ou o Continente Africano, poucas são as informações sistematizadas existentes sobre a cooperação técnica empreendida pelo Ministério da Saúde brasileiro no Haiti. Muito do que será aqui apresentado resulta da coleta de dados nos relatórios publicados pelo próprio MS e em escassos trabalhos que tratam do tema (Pessôa et al., 2013; Misoczky et al., 2015; Gomes e Oliveira, 2015), já que são ainda inexistentes publicações sobre o papel que é desempenhado por suas secretarias e respectivas unidades envolvidas na questão haitiana. Parte-se do pressuposto que, constatado que o esse ministério foi, entre os seus pares, aquele que mais cooperou tecnicamente com o Haiti durante o governo Lula, é fundamental que esta lacuna seja preenchida a partir da análise de como se deu a operacionalização política-institucional da CTPD. Por um lado, pelo fato daquele país ter sido um marco da PEB no período analisado e, por outro, por fornecer pistas de como as burocracias ministeriais são chamadas pelo governo a colaborar a partir de sua expertise técnica.

A pesquisa empírica será realizada a partir do estudo de caso do Projeto de Cooperação Sul-Sul de Fortalecimento da Autoridade Sanitária do Haiti, assinado em novembro de 2010, que foi resultado do Memorando de Entendimento para o Fortalecimento do Sistema e dos Serviços Públicos de Saúde e de Vigilância Epidemiológica no Haiti, celebrado em março daquele mesmo ano pelo então ministro José Gomes Temporão. Assim, serão levantadas informações a respeito do processo decisório compreendido desde a entrada da questão na agenda presidencial, até as ações adotadas pelas diferentes secretarias do MS para a consecução do projeto. 
O principal objetivo deste último capítulo é desenvolver uma análise partindo de três níveis intrínsecos ao processo de tomada de decisão: i) a atenção conferida por Lula ao Haiti; ii) a delegação de competências ao MS e iii) o grau de discricionariedade envolvido nesta último. Para isso, serão analisados dois elementos fundamentais à discussão sobre a teoria da delegação - centralização e politização -, contextualizados pelo regime

presidencialista de coalizão brasileiro. A partir deles buscar-se-á verificar como a utilização destes dois mecanismos, por parte do presidente Lula, garantiu a execução de seu agenda-setting. Além disso, serão apresentados os perfis profissional e político de seus ministros e suas principais contribuições para a pasta no que tange à política externa, e principalmente, os embates ocasionados pela pressão exercida pela disputa política entre o governo, a coalizão governamental, e a oposição quando da nomeação dos mesmos.

Uma última questão a ser analisada, diz respeito aos elementos jurídicos e institucionais que versam sobre a organização do MS no que diz respeito à atribuição das competências e ao espaço conquistado ao longo dos dois mandatos de Lula para a criação das condições necessárias para sua expressiva atuação na PEB, bem como sobre a elaboração do ciclo de fases da CTPD em saúde a partir das etapas político-gerencial (decisão) e políticotécnica (implementação).

\section{A Cooperação Internacional em Saúde no Brasil}

O processo de globalização tem criado grandes disparidades internacionais, sendo que as áreas social e da saúde são as mais sensíveis diante deste contexto, sobretudo naqueles países que estão mais à margem da economia global, os quais carecem de condições mínimas para a implementação de uma sólida governança capaz de enfrentar os problemas de suas populações. Estes locais, além de sofrerem com a carência de profissionais de saúde capacitados e/ou bem remunerados, possuem sistemas de saúde considerados frágeis e desprovidos de recursos tecnológicos (Almeida et al., 2010; Buss e Ferreira, 2010; Kickbusch e Berger, 2010).

Diante desta realidade, a comunidade internacional, seja por intermédio da Organização das Nações Unidas (ONU) ou da atuação de ONGs especializadas, tem buscado responder a esses problemas de maneira efetiva, levando a questão da saúde para as discussões sobre 
os objetivos a serem alcançados para que possa haver um pleno desenvolvimento dos países mais pobres. Surge justamente deste esforço, o conceito de saúde global, na tentativa de buscar soluções conjuntamente por meio do compartilhamento de responsabilidades e experiências entre os atores, fazendo com que essas questões ganhem destaque com cada vez mais frequência em negociações multilaterais (Kickbusch e Berger, 2010).

Um ponto a ser ressaltado na busca pela sua efetivação é a cooperação internacional entre os países, que não obstante, é realizada a partir de diferentes interesses, motivações e estratégias, sendo, por isso, mediada por agências multilaterais com destaque para a própria ONU. Em setembro de 2000, líderes mundiais reuniram-se em Nova York e adotaram a Declaração do Milênio da ONU, documento que estabeleceu um compromisso dos governos com a redução da pobreza extrema através de oito objetivos, que ficaram conhecidos como os Objetivos de Desenvolvimento do Milênio (ODM) ${ }^{30}$, com o prazo de alcance estabelecido para 2015. Três deles estavam relacionados à saúde: (4) reduzir a mortalidade infantil; (5) melhorar a saúde materna; e (6) combater o HIV/Aids, a malária e outras doenças. Da avaliação feita pela ONU em 2015, é possível dizer, de modo geral, que os resultados foram positivos, embora ainda existam deficiências a serem contornadas (ONU, 2015) $)^{31}$.

\footnotetext{
${ }^{30}$ Os oito objetivos são: (1) Erradicar a pobreza extrema e a fome; (2) Alcançar a educação primária universal; (3) Promover a igualdade de gênero e capacitar as mulheres; (4) Reduzir a mortalidade infantil; (5) Melhorar a saúde materna; (6) combater o HIV/AIDS, a malária e outras doenças; (7) Assegurar a sustentabilidade ambiental e (8) Desenvolver uma parceria global para o desenvolvimento.
}

${ }^{31}$ Em 2015, foi publicado pela ONU o relatório sobre os ODM. Em relação aos três objetivos mencionados que tratam de questões de saúde, observaram-se os seguintes resultados. (4) Mortalidade Infantil: a taxa global de mortalidade infantil caiu em mais de metade entre 1990 e 2015, de 90 para 43 mortes por 1000 nascidos vivos. Apesar do crescimento da população em regiões em desenvolvimento, o número de mortes de crianças com menos de cinco anos diminuiu de 12,7 milhões em 1990 para quase 6 milhões em 2015 a nível global. Desde o início da década de 90, a taxa de redução da mortalidade abaixo dos cinco anos mais que triplicou também em nível global. Na América Latina, entre 1990 e 2015, a taxa de mortalidade abaixo dos cinco anos a cada 1000 nascidos vivos, caiu de 54 para 17, atingindo uma redução de $69 \%$. O Brasil, de um modo geral, alcançou a meta ainda em 2011, passando de 53,7 para 17,7 óbitos por 1000 nascidos vivos naquele ano. A taxa de mortalidade de crianças com menos de um ano de idade, passou 47, $1 \mathrm{em}$ 1990 para 15,3 em 2011. (5) Saúde Materna: Desde 1990 a taxa de mortalidade materna diminuiu em 45\% a nível global, sendo que em 2014, mais de $71 \%$ dos partos foram assistidos por pessoal de saúde qualificado, um aumento em relação aos 59\% de 1990. De qualquer modo, nenhuma região alcançou a meta estabelecida pela ONU, sendo que na América Latina, entre 1990 e 2013, a taxa de mortalidade materna para cada 100 mil nascidos vivos entre mulheres de 15 a 49 anos, passou de 130 para 77, representando uma queda de $40 \%$. O Brasil, por sua vez, também enfrenta grandes desafios para alcançar a redução da mortalidade materna, ao passo que cabe ressaltar que o seu desempenho foi melhor que as médias 
Em grande medida, este trabalho é desenvolvido por intermédio de suas agências setoriais como a Organização Mundial da Saúde (OMS); o Fundo das Nações Unidas para a Infância (Unicef); o Programa das Nações Unidas para o Desenvolvimento (PNUD), entre outras organizações internacionais formais. Não obstante, muitos países implementam a cooperação internacional a partir de suas próprias agências de cooperação, sobretudo os mais desenvolvidos, como por exemplo, os Estados Unidos, Canadá, países europeus, Japão, entre outros. Ainda que em menor volume e com quantidade inferior de recursos, países em desenvolvimento também prestam cooperação entre si, como é o caso do Brasil.

No continente americano, a importância da questão da saúde nas relações internacionais possui particularidades históricas, cabendo destacar que pari passu à criação da OMS em 1948, a região já contava com uma Organização Internacional (OI) formal, a Oficina Sanitária Pan-Americana, criada em 1902, e que foi percursora da atual Organização PanAmericana da Saúde (Opas) - posteriormente incorporada ao sistema da ONU como um braço regional da OMS. A Opas é considerada uma importante agência promotora de cooperação entre os Estados americanos, criando oportunidades de interação em âmbito multilateral e bilateral. Cabe à ela a promoção de diversas iniciativas realizadas a fìm de influir na quantidade, qualidade, perfil e modo de atuação do profissional médico e do trabalhador em saúde (Pires-Alves et al., 2010; Santana, 2010).

registradas entre os países em desenvolvimento e na América Latina, passando de 141 em 1990, para 64 óbitos por 100 mil nascidos vivos em 2011, com queda de 55\%. Em relação ao segundo indicador, em 2011, 99\% dos partos foram realizados em hospitais ou outros estabelecimentos de saúde, e aproximadamente $90 \%$ das gestantes fizeram quatro ou mais consultas pré-natais. (6) Combate ao HIV/Aids, Malária e outras doenças: as nova infecções por HIV diminuíram em cerca de $40 \%$ entre 2000 e 2013, de cerca de 3,5 milhões de casos para 2,1 milhões a nível global. Em junho de 2014, 13,6 milhões de pessoas que viviam com HIV recebiam terapia antirretroviral (TAR), um aumento em relação aos $800000 \mathrm{em} 2003$. A TAR evitou 7,6 milhões de mortes por Aids entre 1995 e 2013. Na América Latina, o número estimado de novas infecções pelo HIV/Aids passou de $96 \mathrm{em} 2000$ para $94 \mathrm{em}$ 2013. No Brasil, a taxa de detecção de HIV/Aids estabilizou-se entre 2001 e 2012, em torno de 20 por 100 mil habitantes diagnosticados por ano. Entre crianças menores de cinco anos, os registros também caíram, passando de 5 para 3,4 por 100 mil habitantes. Estimava-se que, em 2012, 718 mil brasileiros tinham HIV/Aids, representando uma prevalência de 0,4\% da população, sendo que deste total, 574 mil haviam sido diagnosticados, 436 mil foram atendidos nos serviços de saúde e 313 mil (44\%) estavam em terapia retroviral. Em 1990 foram notificados 51,8 novos casos de tuberculose por 100 mil habitantes, ao passo que em 2011, esta taxa caiu para 37 por 100 mil habitantes. Entre 1990 e 2012, a incidência parasitária anual (IPA) de malária, por sua vez, caiu de 3,9 para 1,3 casos por mil habitantes. Por fim, em relação a taxa de deteç̧ão de hanseníase, esta caiu de 21,6 em 1994 para 17,2 novos caos anuais por 100 mil habitantes em 2012 (Brasil, 2014; ONU, 2015a; ONU, 2015b). 
De acordo com Pires-Alves et al. (2010), essas OIs atuam simultaneamente como atores em arenas de negociação intergovernamentais e também como atores sociais de grande relevância e agendas de parcerias com a sociedade civil. As OIs são consideradas atores porque possuem a capacidade de gerar incentivos e "produzir realidades" enquanto responsáveis pela criação e disseminação de valores, normas e modelos de atuação. E são também arenas de negociação, uma vez permeáveis à presença de diversos interesses, sejam eles de natureza estatal, infra-estatal ou extra-estatal. Além disso, como frisam os autores, eles são arenas também porque sustentam interesses inerentes à própria agência, manifestos através de suas burocracias enquanto expressões concorrentes, haja vista que suas representações localizadas em diferentes países são sensíveis também "ao jogo de forças presentes nos ambientes institucionais com os quais se relacionam diretamente" (p. 69).

No âmbito da Opas, essas ações de cooperação internacional em saúde, ao longo das décadas de 1960 e 1970, foram seriamente influenciadas por uma nova dimensão e significado que estavam relacionados à emergência do conceito de desenvolvimento, a partir do qual, os temas pertinentes à área passaram a ser tratados a partir de um enfoque educativo e de planejamento, contribuindo para a orientação e implementação de políticas públicas, mediante o desenvolvimento do conceito de Economia da Educação. A Opas refletiu esta tendência, a partir da criação, em 1960, de uma área operacional voltada ao desenvolvimento de recursos humanos, agindo a partir de maior articulação e integração com os planos nacionais de saúde dos Estados (Pires-Alves et al., 2010).

No Brasil, o Ministério da Saúde beneficia-se da cooperação estabelecida com essa OI para o desenvolvimento de parcerias internacionais e a disseminação de políticas de saúde, interagindo entre os planos local e global. Os primeiros passos na implementação de uma cooperação técnica entre eles foram dados no final de 1973 e privilegiaram a capacitação interna em recursos humanos para a saúde, quando foi assinado pelo Ministério da Saúde, da Educação e Cultura e a OI, o Acordo para um Programa Geral de Desenvolvimento de Recursos Humanos em Saúde, que teve como desdobramento, em 1976, o seu programa de ação fundador, Programa de Preparação Estratégica de Pessoal em Saúde, o PPREPS, que "teria como meta formal ajustar a formação de recursos humanos para a saúde no país às necessidades do recém criado Sistema Nacional de 
Saúde e em acordo com as diretrizes do II Plano Nacional de Desenvolvimento, ambos de 1975" (Pires-Alves et al., 2010; p. 69).

Este foi o início do desenvolvimento de um projeto de cooperação que aliaria definitivamente a saúde pública com a política externa brasileira, concedendo ao MS, enquanto entidade político-administrativa, estruturas organizacionais e processos decisórios para se projetar legal e institucionalmente no plano externo. Não obstante, é possível identificar desde a década de 1970 até os anos 1990, um processo contínuo de aperfeiçoamento das políticas de saúde do ministério, que com o passar dos anos, por sua vez, consolidaram-se em importantes experiências bem sucedidas e tornaram-se modelos para países que lidavam com os mesmos problemas. A tabela seguinte representa de maneira sucinta as principais dentre elas:

\begin{tabular}{|c|c|}
\hline Política & Síntese \\
\hline $\begin{array}{c}1970 \text { - Programa Nacional de } \\
\text { Imunizações (PNI) }\end{array}$ & $\begin{array}{l}\text { Responsável por controlar e/ou erradicar ao longo de seus hoje } 42 \text { anos de existência, } \\
\text { as principais doenças passíveis de prevenção por meio de vacinação, como são os } \\
\text { casos de febre amarela, varíola, poliomielite, sarampo, tétano etc. Destaca-se a adoção } \\
\text { de três estratégias complementares para a obtenção destes resultados: } 1 \text { ) as campanhas } \\
\text { de vacinação; 2) o desenvolvimento e aperfeiçoamento de tecnologias e políticas para } \\
\text { a logística dos imunobiológicos, o que resultou na criação e aperfeiçoamento da Rede } \\
\text { de Frio } 2 \text {; e 3) a adoção do Programa de Autossuficiência Nacional em } \\
\text { Imunobiológicos (Pasni) a partir do qual foram feitos investimentos em capacitação } \\
\text { profissional e desenvolvimento de tecnologia nacional para a produção de novas } \\
\text { vacinas a partir da recuperação, modernização e construção de laboratórios. Estas } \\
\text { medidas, em conjunto, tornaram o PNI um dos mais respeitados programas em saúde } \\
\text { pública do mundo, sendo continuamente citado pela Opas como uma referência global } \\
\text { (Ministério da Saúde, 2003). }\end{array}$ \\
\hline 1980 - Sistema Único de Saúde (SUS) & $\begin{array}{l}\text { Em } 1988 \text { a reforma sanitária atingiu um destacado patamar com a definição } \\
\text { constitucional do Sistema Único de Saúde (SUS), que passou a ser implantado nos } \\
\text { anos subsequentes. O SUS foi edificado segundo o princípio da universalidade que se } \\
\text { baseia na premissa de que a saúde dos cidadãos é uma responsabilidade pública. No } \\
\text { contexto internacional, por sua vez, a segunda metade da década foi marcada por uma } \\
\text { onda (neo)liberal embasada na defesa do "Estado Mínimo", enfraquecendo a } \\
\text { capacidade dos governos em oferecer serviços públicos de qualidade aos cidadãos. A } \\
\text { reforma da saúde proposta pelo Brasil seguia em sentido inverso, o que a tornou uma } \\
\text { experiência absolutamente singular (Alves et.al, 2010). }\end{array}$ \\
\hline $\begin{array}{c}1990 \text { - Prevenção e Tratamento do } \\
\text { HIV/Aids }\end{array}$ & $\begin{array}{l}\text { A luta contra a AIDS no Brasil iniciou-se a partir da realização da VIII Conferência } \\
\text { Nacional de Saúde em } 1986 \text { e a proposição do SUS em 1988, pari passu à } \\
\text { disseminação do vírus HIV durante a década de } 1980 \text {. Em } 1985 \text { foi fundada a primeira } \\
\text { ONG preocupada com a questão, o Grupo de Apoio à Prevenção da AIDS (GAPA), } \\
\text { além de terem sido criados os Programas Estaduais de DST/AIDS em } 10 \text { estados. } \\
\text { Neste ensejo, o MS além de veicular campanhas sobre a prevenção da doença, criou } \\
\text { o Programa Nacional de DST e AIDS (PN-DST/AIDS), ainda em 1986, que por sua } \\
\text { vez, foi considerado em } 2003 \text { referência mundial por diversas agências internacionais. } \\
\text { Este reconhecimento deu-se por duas principais razões: i) a oferta universal e gratuita }\end{array}$ \\
\hline
\end{tabular}

${ }^{32}$ Rede de Frio, ou Cadeia de Frio, é o processo de armazenamento, conservação, manipulação, distribuição e transporte dos imunobiológicos do Programa Nacional de Imunizações (PNI), desde o laboratório produtor até o momento em que a vacina é administrada. $\mathrm{O}$ objetivo da rede, equipada com câmaras de frio e transporte igualmente refrigerado, é assegurar que todos os imunobiológicos oferecidos à população mantenham suas características iniciais (Ministério da Saúde, 2003). 


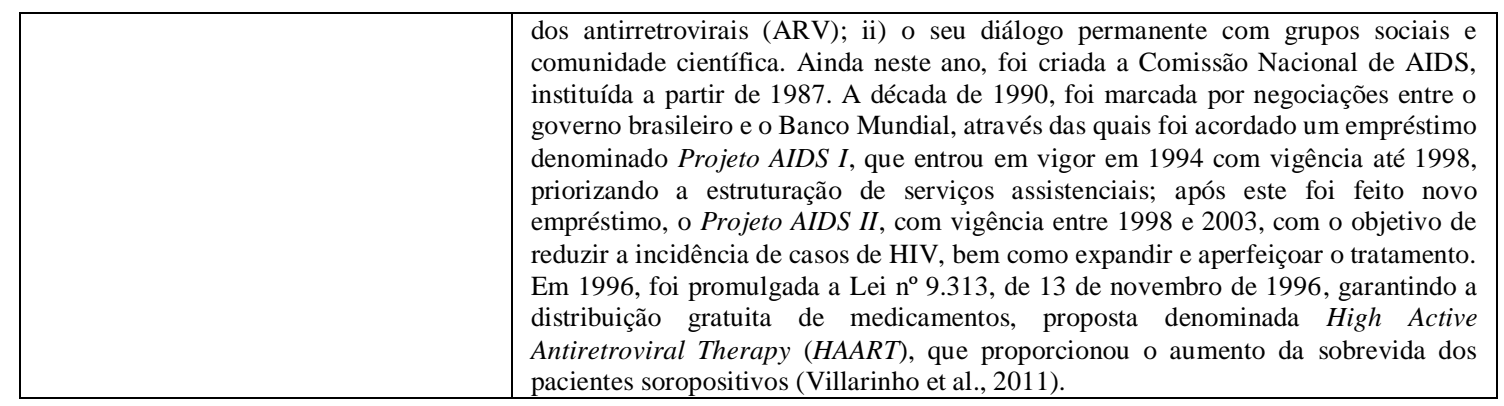

Fonte: elaborado pela autora

Se no período inicial da parceria Brasil-Opas, o país beneficiou-se largamente da cooperação oferecida pela OI no desenvolvimento do campo da saúde internamente, no momento subsequente, quando passou a prestar CT a países igualmente em desenvolvimento, ela tornou-se uma importante estratégia de mediação, operando como catalisadora de possibilidades de cooperação e também cumprindo a tarefa de acompanhar o processo no qual estão envolvidas as iniciativas. Isso inclui a articulação de redes colaborativas nacionais e redes regionais na América Latina e África; a identificação de docentes capacitados para ofertarem cursos em áreas como gestão de políticas e recursos humanos; a promoção da saúde global junto à diplomacia da saúde; o direito sanitário; o desenvolvimento de políticas públicas domésticas com foco em saúde pública; entre outros (Pires-Alves, et al., 2010).

Principalmente a partir de 2003, algumas iniciativas internacionais, por parte do governo brasileiro, passaram a ser amplamente destacadas quando o então secretário de Gestão Participativa do MS, Sérgio Arouca, advogou para que a reforma sanitária, então consolidada com a criação do SUS, passasse a ser internacionalizada como forma de contribuição às atividades internacionais. Surgiu, então, naquele ano, o esboço do Programa de Difusão e Intercâmbio sobre Reforma Sanitária (Prodirs), que contou com o trabalho conjunto do MS e da representação Opas-Brasil no país.

Após estas discussões iniciais, a inserção internacional no setor ascendeu paulatinamente no campo da CT, cabendo destacar alguns eventos-chave: i) a assinatura por Humberto Costa e Celso Amorim, ministros da Saúde e das Relações Internacionais, respectivamente, de um protocolo de intenções que tinha como objetivo o aperfeiçoamento da coordenação da CTPD na área (2005); ii) a celebração entre o MS, a Opas e a Fiocruz, do Termo de Cooperação n41 (2006), reconhecido como um dos principais mecanismos estabelecidos com o propósito de realizar a CT; e iii) o lançamento 
nacional do Programa Mais Saúde: Direito de Todos, apresentado como a estratégia de desenvolvimento do MS para o período de 2008 a 2011, que possuía um eixo específico sobre a cooperação internacional (Pires-Alves et al., 2010) ${ }^{33}$.

Desde então, muitas têm sido as discussões sobre a relação entre saúde e cooperação internacional que, em grande medida, reafirmam o fato de que o MS tem buscado desenvolver mecanismos capazes de conceber, facilitar e implementar ações de cooperação na área, que são empregadas a partir de quatro linhas fundamentais: i) o diálogo continuo com a política diplomática adotada pelo país, buscando sua inserção no contexto global ou blocos regionais e sub-regionais do qual participa; ii) a consideração das questões de vulnerabilidade dos países com os quais coopera; iii) envolvimento em organismos da ONU; e iv) execução dos projetos em parceria com instituições nacionais, enquanto promotoras e beneficiárias do desenvolvimento científico e tecnológico inerente à política de cooperação (Almeida et al., 2010; Buss e Ferreira, 2010; Santana, 2010; Milani e Nunes, 2014).

Além da atuação multilateral, quando solicitado a colaborar, o MS transfere seus conhecimentos e expertise ora de maneira bilateral, por meio de projetos e trabalhos executados com duas ou mais instituições de dois países parceiros, ora através de triangulação, quando obtém o apoio financeiro de uma Agência de Cooperação estrangeira. As demandas por cooperação são maiores principalmente nas áreas consideradas de experiência comprovada do MS tais como: malária; HIV/AIDS; Sistema Único de Saúde; Nutrição; Banco de Leite Humano; Vigilância Ambiental em Saúde; Vigilância Epidemiológica; Geminação de Hospitais; Fármacos e Imunobiológicos ${ }^{34}$ (Via

\footnotetext{
${ }^{33}$ Nos anos 2000, diante da crescente complexidade dos problemas em saúde, ocorreram diferentes ações internacionais, tais como os Objetivos de Desenvolvimento do Milênio (ODM, 2000); as Iniciativas Globais em Saúde (Global Health Initiatives - GHIS, 2000); a Comissão de Macroeconomia e Saúde (2001); a Comissão de Determinante Sociais da Saúde (2005 - 2008); a Declaração de Oslo (2007) e a Celebração Mundial dos 30 anos da Conferência de Alma-Ata (2008) (Almeida et al., 2010).

${ }^{34}$ O Ministério da Saúde recebe, ainda, demandas em outras áreas, além das mencionadas, como Saúde Mental, Saúde Indígena, Gestão Participativa, Bancos de Sangue, Cirurgias Cardíacas, Tratamento de Queimados, entre outras. Em 2009 os países com o quais cooperava no eixo Sul eram: América do Sul: Argentina, Bolívia, Chile, Colômbia, Equador, Guiana, Paraguai, Peru, Suriname, Uruguai, Venezuela. América Central: Panamá, Costa Rica, Nicarágua, El Salvador, Hunduras, Belize, México. Caribe: Cuba, República Dominicana, Haiti, Granada. África Lusófona: Angola, Cabo Verde, Guiné Bissau, Moçambique, São Tomé e Príncipe. África Anglófona: Botsuana, Gana, Quênia, Zâmbia, Tanzânia, África Francófona: Argélia, Benin, Burkina Fasso, Cameroun, Senegal e Congo (Ministério da Saúde, 2010a).
} 
ABC, 2007). O gráfico a seguir demonstra o percentual de projetos de cooperação SulSul por área:

Gráfico 5. Principais Projetos de Cooperação Sul-Sul em Saúde por Área (2009)

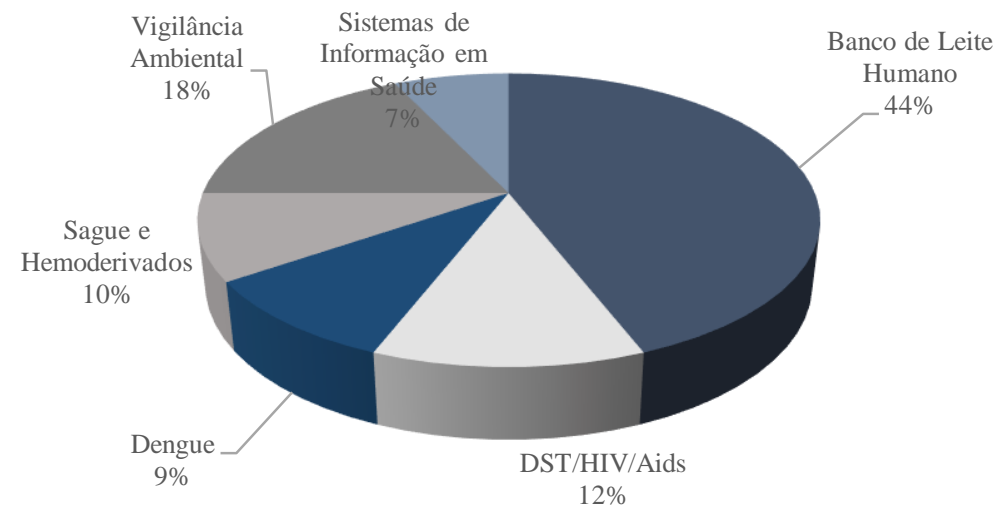

Fonte: Ministério da Saúde, 2010a.

Essas ações internacionais do MS, por sua vez, são todas coordenadas pela Assessoria de Assuntos Internacionais (AISA), criada em 1998, no momento de maior projeção internacional do ministério atribuída aos resultados alcançados pela política de combate à Aids. À AISA cabe a contribuição na formulação da política externa do ministério, bem como na difusão dos projetos e programas de cooperação internacional; além disso, ela é responsável por coordenar as ações na área internacional por meio da mediação entre os distintos programas e unidades do MS e do MRE e também apoiar as áreas técnicas na identificação, negociação e elaboração de projetos de cooperação técnica internacional (Ministério da Saúde, 2010a).

Este trabalho é executado principalmente pela sua Divisão de Projetos (DPROJ) que cumpre as seguintes funções: i) contribuir na formulação de política externa na área de saúde; ii) contribuir para a difusão dos projetos e programas de cooperação internacional no ministério; iii) coordenar as ações na área internacional, traçar diretrizes e contribuir para o desenho e implementação de programas e ações em cooperação internacional, realizando a intermediação entre os distintos programas e unidades do MS e do MRE; iv) apoiar áreas técnicas da saúde na identificação, negociação, elaboração de projetos de CI, bem como participar nos esforços de captação de recursos para sua implementação; v) 
definir diretrizes e coordenar os esforços no âmbito das distintas áreas do MS para que as ações tenham o devido impacto e o esperado resultado, de acordo com as diretrizes previamente estabelecidas, que por sua vez, devem estar em consonância com os propósitos maiores da PEB (papel articulador); vi) coordenar e gerenciar as ações de assistência humanitária; e vii) monitorar e avaliar os programas, projetos e ações da área internacional ${ }^{35}$.

Essas informações apontam para uma ativa articulação do MS na agenda de política externa. Com o avanço da cooperação, o ministério tornou-se mais capacitado para atender às demandas, dotando sua burocracia de competência suficiente para responder diretamente às questões envolvidas com o tema. Ao mesmo tempo, a tecnicalidade envolvida na consecução desse tipo de política significou a perda relativa da capacidade de gerência do MRE, ao qual coube, principalmente, atuar na esfera diplomática, acompanhando ministros e técnicos do ministério em reuniões multilaterais, e organizando, de forma geral, a gestão regulatória da política através da ABC (Pimenta de Faria, 2012b).

Pela definição de Souza (2006a), já apresentada anteriormente, os dois ministérios estabeleceram durante esse processo de divisão de tarefas, uma relação cooperativa, compartilhando a mesma autoridade centralizadora de decisões, ou seja, a Presidência da República. Deste modo, é central para a análise entender de que forma o presidente articulou a ampliação da autonomia burocrática do MS para atuar em política externa, ao mesmo tempo em que garantiu que sua agenda internacional fosse observada e implementada.

\footnotetext{
35 Dentre as principais iniciativas estratégicas do DPROJ estão: (1) Grupo Temático de Cooperação Internacional em Saúde (GT-CIS), instituído por meio da Portaria ministerial 2.356, de 17/08/2010, que conta com um representante de cada secretaria e tem por objetivo institucionalizar e fortalecer o diálogo e a articulação entre as áreas técnicas do MS para temas relacionados à cooperação internacional; (2) Sistema de Acompanhamento de Projetos e Atividades de Cooperação (Siscoop), através do qual foi possível sistematizar as informações disponíveis na Assessoria Internacional acerca de projetos e iniciativas de cooperação internacional, permitindo uma resposta mais ágil e eficiente, bem como uma melhor coordenação de todos os processos em curso nos países cooperados com as distintas áreas e unidades vinculadas do MS, estando a partir de 2010 também disponível online para consulta pública; (3) Fortalecimento das ações de assistência humanitária, em que foram tomadas algumas providências para solucionar questões jurídicas e administrativas no sentido de viabilizar maior rapidez no fluxo da tramitação e fortalecimento das ações de Assistência Humanitária.
} 
Uma maneira de verificar esta questão, é analisando os limites impostos pelo presidente ao exercício do poder discricionário do MS; limites estes que podem ser verificados a partir de duas variáveis: i) a nomeação dos ministros e ii) os decretos presidenciais que regem a estrutura dos cargos no interior do ministério. A próxima seção, buscará justamente analisar o jogo político no qual inseriu-se a primeira varável, bem como observar se os decretos presidenciais possuíram de fato, capacidade de limitar a atuação do MS em política externa.

\section{A Delegação Política do ex-Presidente Lula ao Ministério da Saúde em Política Externa}

\subsection{A Nomeação dos Ministros}

No primeiro capítulo foram apresentados alguns trabalhos da Ciência Política brasileira que tratam dos problemas oriundos da delegação no interior do poder executivo em um contexto marcado pelo presidencialismo de coalizão, tanto no que diz respeito à política doméstica quanto à execução da agenda de política externa partindo do pressuposto das pesquisas norte-americanas de que existe um controle exercido pelo presidente sobre as burocracias $^{36}$.

Utilizando este referencial teórico, é possível dizer de antemão que ambos os mecanismos de controle levantados por essas discussões, a centralização e a partidarização, influenciaram enormemente para a consecução dos resultados obtidos durante os dois mandatos do presidente Lula, no campo da CTPD, particularmente em saúde, garantindo à política externa de seu governo um status diferenciado perante à comunidade internacional no que diz respeito à difusão de boas práticas da política nacional de saúde brasileira.

\footnotetext{
${ }^{36}$ Para política doméstica ver (Loureiro e Abrucio, 1999; Ignácio, 2006; D’Araújo, 2009; Vieira, 2013; Batista, 2014; Lopez et al.; Borges e Coêlho; Lopez e Praça; Pereira et al.; Lameirão, 2015). Para política externa ver (França e Badin, 2010; Silva et al., 2010; Pinheiro e Beshara, 2011; Pimenta de Faria, 2012a, 2012b; Albuquerque, 2013; Leite et. al, 2013; Milhorance, 2013; Milani 2014; Milani e Lopes, 2014). Para os estudos norte-americanos ver ((Neustadt, 1960; Krasner, 1972; Rosati, 1981; Weingast\& Moran, 1983; Moe, 1984; King, 1993; Moe, 1993; Bawn, 1995; Epstein andO’Halloran, 1994; Moe and Wilson, 1994; Lupia, 2001; Carpenter, 2001; Howelland Lewis, 2002; Hawkins et al., 2006; Lewis, 2007; Burke, 2016).
} 
A centralidade exercida pela Casa Civil, diretamente ligada ao presidente, tanto em relação à nomeação dos cargos de alto-escalão do governo e na revisão das propostas políticas elaboradas pelos ministérios, quanto na nomeação de ministros - ainda que nem todos de seu partido, mas com orientações pró-governo -, foram importantes mecanismos de controle ex ante utilizados pelo presidente Lula no gerenciamento do Ministério da Saúde.

Esse ministério sempre foi uma das pastas mais cobiçadas da Esplanada, por um lado, muito em razão do volume de recursos destinado às políticas públicas setoriais, visto que no primeiro ano do primeiro mandado do presidente Lula (2003), por exemplo, ele possuía o segundo maior orçamento entre seus pares ${ }^{37}$; por outro, ele logrou alcançar, no decorrer de sua história, uma boa reputação no desenvolvimento e aprimoramento das políticas, ações e programas do setor, garantindo um papel de vitrine política para os partidos, de modo que não é sem razão a disputa pelo seu controle.

Na sucessão de dois dos quatro ministros que foram nomeados pelo presidente Lula de 2003 a 2010, ele arcou com os custos impostos pela formação de sua coalizão, sendo o mais alto deles, a perda do ministério pelo seu partido para o PMDB em 2005, com o qual permaneceu até o final de seu segundo mandato. Não menos importante foi a dificuldade de, ainda assim, manter-se coeso com a base peemedebista no Congresso e buscar pautar as demais nomeações em caráter estritamente técnico, para que sem retomar o ministério para o PT e provocar rupturas com a base aliada, pudesse controlar a influência política do PMDB naquelas políticas que vinham sendo desenvolvidas pelo MS.

Quando assumiu a presidência, o presidente Lula nomeou Humberto Sérgio Costa Lima, que integrava o partido do presidente desde 1981, tendo ocupado cargos legislativos pelo

\footnotetext{
${ }^{37}$ De acordo com a Lei Orçamentária n ${ }^{\circ} 10.640$ de 14 de janeiro de 2003, o orçamento do MS previsto para aquele ano era de $\mathrm{R} \$ 30.562 .133 .942$, o que o deixava atrás apenas do Ministério da Previdência e Assistência Social, que tinha um orçamento previsto de R $\$ 109.651 .575 .329$. Além destes dois, outros altos orçamentos eram: Ministério da Defesa ( $\mathrm{R}$ \$ 26.272.355.773); Ministério da Educação (R\$ 17.350.409.917); Ministério do Trabalho e Emprego (R \$ 15.691.732.976) e Ministério dos Transportes (R\$ 10.927.581.803). Disponível em http://www.orcamentofederal.gov.br/orcamentos-anuais/orcamento2003/lei_10640_anexo.pdf (Acesso em 15 de maio de 2016).
} 
estado de Pernambuco entre fevereiro de 1995 a janeiro de 1999. Não obstante fosse médico de formação, com uma carreira consolidada e reconhecida na área, o então ministro gozava da confiança de Lula que, seguro de nomear um nome de seu próprio partido, contaria com total apoio do mesmo para a execução de sua agenda política. $\mathrm{O}$ que foi demonstrado pela prática, pois apesar do pouco apoio do Congresso e de contumazes críticas, Humberto Costa implementou uma gama de propostas populares que estavam em íntimo diálogo com as diretrizes do governo, cabendo destacar a Política Nacional de Saúde Bucal - Brasil Sorridente (2003), a Política Nacional de Urgência e Emergência (SAMU - 2003), e o Programa Farmácia Popular (2004).

Outro nome importante do Ministério, ainda nessa gestão, foi o sanitarista Sérgio Arouca, nomeado para a Secretaria de Gestão Participativa. Ele ficou reconhecido por sua militância durante a reforma sanitária brasileira da qual originou-se o SUS em 1988, além de ocupar importantes postos durante sua trajetória, como por exemplo, a presidência da Fiocruz e de ter sido consultor da Opas, dentro da qual atuou em diversos países, experiência esta que o faria privilegiar, quando nomeado para o MS em 2003, a internacionalização das políticas públicas brasileiras em saúde, seguindo as diretrizes da política externa do governo.

Entretanto, controversas políticas definiram o contexto da sucessão de Costa Lima, marcado por divergências entre o PT e PMDB que advinham desde antes da posse do presidente Lula em 2003. José Dirceu, nome forte do partido do presidente e então ministro chefe da Casa Civil, após inúmeros processos de negociação, acabou por acertar a participação peemedebista no governo, sendo, entretanto, contrariado pelo presidente Lula que, não satisfeito, recuou da decisão e negou-se a abrir um espaço para o partido no governo. Fortemente criticado pelo PMDB, apenas um ano depois, o então presidente nomeou Eunício Oliveira para o Ministério das Comunicações e Amir Lando para a Previdência Social, ambos filiados ao PMDB. Ainda que decorrido um ano, e ambos tenham saído, o presidente entregou o Ministério de Minas e Energias a Silas Rondeau, o Ministério das Comunicações a Hélio Costa e finalmente o Ministério da Saúde a José Saraiva Felipe, já em 2005.

As discussões geradas por esse embate político e a consequente nomeação de Saraiva Felipe produziram duras críticas por parte da oposição, a imprensa e em parte também da 
população, ao que chamavam de 'politização' da Esplanada dos Ministérios. Em entrevista concedida no dia de sua posse, o então ministro disse que estavam ocorrendo debates de cunho preconceituoso contra os políticos (entre 1995 e 2005, ele havia sido deputado federal por Minas Gerais, além de líder do partido na Câmara dos Deputados neste último ano, quando licenciou-se para assumir o ministério). O que ele alegava em sua defesa como nomeado para titular da pasta, era que as pessoas estavam esquecendose de sua trajetória profissional e política, pois além de médico de formação e atuante na área da saúde, ele havia sido um dos integrantes das discussões sobre a reforma sanitária brasileira, ainda na década de 1980 .

Quando assumiu o cargo, Saraiva Felipe garantiu ao presidente Lula que ele poderia contar com o apoio da maioria do seu partido na Câmara dos Deputados, pois todos estavam de acordo acerca da necessidade de colaborar com a gestão do presidente no sentido de formar um "mesmo governo"; e se, tornar-se ministro da Saúde significava politizar o ministério, ele o faria, não enquanto sinônimo de partidarizar ou dificultar o consenso, mas "de [estabelecer] um ministério político no sentido de estar aberto ao diálogo e cujas decisões [passassem] pelo Conselho Nacional de Saúde"38 .

Suas palavras funcionaram mais no discurso que na prática, porque houve uma grande incapacidade de seu partido em superar as divergências internas, a ponto do presidente Lula queixar-se com o então presidente do Senado, Renan Calheiros, e com o senador José Sarney, ambos do PMDB, que ainda enquanto ministro de seu governo, Saraiva Felipe teria trabalhado em apoio à candidatura de Anthony Garotinho às eleições presidenciais de 2006.

Saraiva Felipe permaneceu no cargo por apenas um ano, pedindo exoneração para lançarse às eleições em Minas, o que abriu precedentes para uma nova discussão sobre a sucessão ministerial. Havia duas possibilidades em jogo, a primeira, que atendia diretamente ao PT, era nomear um nome ligado ao partido, já que o fato de o ano seguinte ser um ano eleitoral, e Lula ser candidato à reeleição, ele não poderia correr o risco de

\footnotetext{
${ }^{38}$ Informação disponível em: http://www6.ensp.fiocruz.br/radis/revista-radis/36/sumula/3113 (Acesso em 10 de maio de 2016).
} 
entregar um de seus principais ministérios a um político ligado ao PMDB, incerto de que a nova gestão garantiria avaliações positivas por parte do eleitorado necessárias à sua possível vitória; atrelado a isso, o PMDB não havia tido sucesso em agregar apoio hegemônico da sua bancada no Congresso para a escolha de um nome, o que deixou vaga a chefia da pasta durante alguns dias.

A outra possibilidade, aventada pelo presidente Lula era buscar a solução ótima diante de um cenário crítico em que, por um lado ele continuaria a precisar do apoio do PMDB, caso reeleito, o que poderia ser afetado caso retirasse o MS do partido; e por outro, cabia a ele garantir com que a gestão de Saraiva Felipe, que alinhada às diretrizes do governo, permanecesse sem alterações. A solução encontrada pelo presidente, ainda que o PMDB tenha indicado dois nomes para a pasta - os deputados Marcelo Castro (PI) e Jorge Alberto (SE) - foi elevar José Álvares da Silva, também do PMDB e homem de confiança de Saraiva Felipe, da função de Secretário-Executivo, para a de Ministro, onde permaneceu até 2007, tudo isso permeado pelo fato de que, diferente de seus sucessores, Álvares da Silva nunca havia exercido funções políticas.

Tomada a decisão e na tentativa de acalmar os ânimos dos líderes do PMDB insatisfeitos com a nomeação feita pelo presidente Lula, ele informou aos senadores Calheiros e Sarney, que não faria nenhuma nomeação política para o MS, ainda que fosse para seu próprio partido, e que sua escolha havia sido feita em bases técnicas, pois tratava-se de um período muito específico de transição. Ele garantiu que todos os recém-nomeados ministros poderiam criar novos programas, embora tivessem sido orientados a concluir aqueles que já se encontravam em andamento, e que se caso nomeasse políticos, estes estariam tentados a dar um "toque pessoal" na gestão ${ }^{39}$.

Um dos problemas decorrentes do processo de politização das burocracias de acordo com a literatura (Moe, 1985; Moe and Wilson, 1994; Ignácio, 2006; Lewis, 2007; Vieira, 2013; Batista, 2014; Lopez et al.; Borges e Coêlho; Lopez e Praça; Pereira et al.; Lameirão, 2015) é o de que, caso não ocorra, a linha de governo adotada pelo presidente pode correr o risco de não ser respeitada pelo fato do agente mudar os interesses do principal no

\footnotetext{
${ }^{39}$ Informações disponíveis em: http://www2.senado.leg.br/bdsffitstream/handlefid/399111/complemento 3.htm?.sequence=4 ehttp://www.anabb.org.br/mostraPagina.asp?codPagina=16203\&codServico=4 (Acesso em 10 de maio de 2016).
} 
processo de delegação, e aproximá-los da bancada do partido presente na coalizão de governo; e no caso inverso, além do risco de eventualmente dirimir a política de seus aspectos morais, coloca sob desconfiança a qualificação pessoal daqueles que são nomeados podendo originar o fracasso de projetos e programas ora em fase de tramitação, ora já implementados, dada a natureza transitória dessas nomeações.

É possível dizer que o presidente Lula não teve escolha diante da pressão exercida pelo PMDB, e acabou cedendo ao partido da coalizão a pasta da saúde, não sem antes ter garantias de que seus interesses estavam relativamente a salvo, para que assim pudesse garantir a continuidade das políticas iniciadas e a sinergia entre elas e o seu plano de governo. De outro modo, tanto Costa Lima quanto Saraiva Felipe possuíam qualificações técnicas necessárias para a condução do ministério, ainda que compartilhassem de uma carreira médica alinhada à política, o que por seu turno, acabou por gerar resultados, se não de todo positivos, pelo menos não desabonadores à avaliação mais geral do setor.

Entretanto, a aposta na tecnicalidade do presidente Lula em Álvares da Silva garantiu uma atuação híbrida da parte do presidente na qual, sem criar desafetos com o PMDB, pôde certificar-se de que o MS não teria interferências indesejáveis que pudessem mudar o curso de sua agenda política. Sem dúvida, foi uma aposta de risco, porque nada poderia garantir que o fato de que o ministro, não tendo ele vínculos diretos com o exercício da política, estaria resguardado da influência do seu partido. Não obstante, a receita parece ter funcionado, fazendo com que em 2007, reconduzido ao segundo mandato ao final de 2006, o presidente Lula nomeasse José Gomes Temporão que permaneceu como ministro até o fim do seu governo em 2010.

Embora tenha passado por diversos partidos ao longo de sua trajetória, o ministro Temporão possuía um alinhamento ideológico com as propostas do partido do presidente, tendo sido filiado ao Partido Comunista Brasileiro (PCB) no final da década de 1970, época em que ingressou na faculdade de medicina. Em 1992, quando seu partido decidiu extinguir a agremiação e fundar um novo partido sem ligações formais com o marxismo, o Partido Popular Socialista (PPS), Temporão desligou-se e entrou no Partido Democrático Trabalhista (PDT), onde ficou até 2005, quando então filiou-se ao PMDB. Esta última filiação foi o que garantiu sua posse como ministro da saúde, ao passo que ela foi resultado da indicação feita pelo governador do Rio de Janeiro, Sérgio Cabral 
Filho, ao presidente Lula. Assim, como os demais que o precederam, o ministro Temporão possuía uma sólida trajetória na área da saúde, tendo participado ao lado de outros médicos sanitaristas entre 1980 e 1982 nos debates sobre a reforma sanitária brasileira. Em seu discurso de posse, enfatizou que sua missão no ministério era a de qualificar o atendimento de saúde da população brasileira e garantir a transparência da utilização dos recursos.

Os dois últimos ministros da pasta na gestão do primeiro mandato do presidente Lula deram grande atenção à agenda de política externa, reflexo de uma extensa carreira na saúde perpassada por atuações na área internacional. Álvares da Silva, por exemplo, foi consultor nacional da Opas entre os anos de 1986 e 1992, sendo que durante a sua gestão no MS instituiu o fórum permanente do Mercosul para o trabalho em saúde. Temporão, por sua vez, também prestou consultoria à Opas em 1984, como assessor temporário para a reunião sobre descentralização e administração dos Sistemas de Saúde, no México. Além disso, em 2001, também como consultor, ficou responsável pelo desenvolvimento de tecnologias e instrumentos de fortalecimento das funções gestoras da rede assistencial do SUS. Já em 2003, como diretor geral do Instituto Nacional do Câncer (INCA), promoveu uma campanha nacional de Doações de Medula Óssea em colaboração com outras instituições científicas nacionais e internacionais, tendo ainda participado, enquanto diretor, no âmbito da OMS, do Grupo de Trabalho Intergovernamental de Composição Aberta da Convenção Quadro para o Controle do Tabaco (CQCT), e do grupo de conselheiros internacionais para o desenvolvimento de uma estratégia global para o controle do câncer.

Em seu mandato como ministro, foi lançado o Programa Mais Saúde: Direito de Todos que, conforme visto anteriormente, possuía um eixo específico sobre a cooperação internacional. Em seu discurso de posse, em 19 de março de 2007, Temporão listou, entre as demais propostas para o ministério: "Fortalecer a presença do Brasil no cenário internacional (atendendo ao desafio lançado pelo presidente Lula durante o congresso da Abrasco) estreitando as relações com o Ministério das Relações Exteriores, amplificando nossa presença nos órgãos setoriais e em programas de saúde das Nações Unidas - como a OMS, a OPAS, a UNITAIDS, o FIAM e tantos outros assim como cooperando com o desenvolvimento dos sistemas de saúde dos países da América do Sul 
- em especial com o Mercosul - e com os países de língua portuguesa da África e a CPLP" (Discurso do Ministro Dr. José Gomes Temporão). ${ }^{40}$

Essas informações demonstram que o desempenho de qualquer ministério, no sentido de estar alinhado às diretrizes da agenda presidencial, depende fundamentalmente do controle exercido pelo presidente, sendo que três exemplos destacados dos acontecimentos políticos narrados acima comprovam esse argumento. O primeiro diz respeito à atitude do presidente Lula ao responder para os principais nomes do PMDB, que sua escolha por Álvares da Silva justificava-se tanto por sua competência técnica quanto pelo receio de que qualquer nomeação política pudesse acarretar em alterações nos objetivos perseguidos pelo governo para o setor, já que, tendo em vista sua intenção de ser eleito novamente presidente em 2006, qualquer avaliação negativa em uma área tão sensível ao crivo popular, poderia custar sua reeleição.

O segundo foi a barganha realizada entre Lula e José Saraiva Felipe quando da nomeação deste para o ministério, em que ele, por sua vez, garantiu ao presidente - dada sua posição privilegiada de líder do PMDB no Congresso - que a sua agenda política não enfrentaria grandes dificuldades para ser implementada. Por fim - e ao que interessa particularmente ao problema da pesquisa -, tem-se a demonstração mais evidente da delegação por parte do ex-presidente ao então ministro Temporão, quando este último, em seu discurso de posse, afirmou que sua gestão no MS buscaria conferir atenção à inserção internacional do país privilegiando as relações com países da América do Sul e África, conforme o desafio lançado pelo presidente Lula para o seu segundo mandato.

Entretanto, conforme dito anteriormente, além da nomeação dos ministros, outra variável capaz de medir os limites impostos pelo presidente ao poder discricionário do MS é a sincronia entre as competências atribuídas ao ministério pelo principal, que pode ser verificada a partir da comparação entre os decretos presidenciais e a estrutura interna do ministério, durante o período analisado. Na sequência, buscar-se-á empreender esta tarefa, comparando os respectivos documentos publicados em 2003 e 2010.

\footnotetext{
${ }^{40}$ Discurso de posse do Dr. José Gomes Temporão no cargo de ministro da saúde em 19 de março de 2007. Disponível em http://www5.ensp.fiocruz.br/biblioteca/home/exibedetalhesBiblioteca.cfm?ID=2959\&tipo=B (Acesso em 10 de maio de 2016).
} 


\subsection{Os Decretos Presidenciais e os Regimentos Internos do MS}

França e Badin (2010) e Silva et al. (2010), como foi demonstrado no capítulo 1, analisaram os órgãos que compõem o Executivo, tal qual os ministérios, a fim de verificar a competência atribuída a seus órgãos internos no que diz respeito à formulação e implementação de política externa, utilizando duas fontes de dados: os decretos presidenciais que determinam sua estrutura regimental e os seus respectivos regimentos internos.

Em relação ao primeiro, esses têm como objetivo demonstrar de maneira simplificada como os ministérios estão organizados, apresentando as principais funções de suas secretarias e demais órgãos que os compõem. No caso do MS, no recorte temporal da pesquisa, foram editados nove decretos, embora nem todos tenham revogado o inteiro teor de seu antecedente, conforme pode ser verificado na tabela:

\begin{tabular}{|c|c|c|c|}
\hline Data & Número & Ementa & Decreto Revogado \\
\hline 09/06/2003 & 4.726 & $\begin{array}{l}\text { Aprova a Estrutura Regimental e o Quadro } \\
\text { Demonstrativo dos Cargos em Comissões e das } \\
\text { Funções Gratificadas do Ministério da Saúde }\end{array}$ & $\begin{array}{l}\text { Decreto } n^{\circ} 4.194 \text {, de } 11 \text { de abril de } \\
2002\end{array}$ \\
\hline $03 / 12 / 2003$ & 4.907 & $\begin{array}{l}\text { Altera a redação do art. } 33 \text { do Decreto } \mathrm{n}^{\circ} 4.726 \text {, de } 9 \\
\text { de junho de } 2003 \text {, que aprova a Estrutura Regimental } \\
\text { e o Quadro Demonstrativo dos Cargos em Comissão } \\
\text { e das Funções Gratificadas do Ministério da Saúde }\end{array}$ & $\begin{array}{l}\mathrm{O} \text { art. } 33 \text { do Anexo I ao Decreto }{ }^{\circ} \\
4.726 \text {, de } 9 \text { de junho de } 2003\end{array}$ \\
\hline $18 / 01 / 2006$ & 5.678 & $\begin{array}{l}\text { Aprova a Estrutura Regimental e o Quadro } \\
\text { Demonstrativo dos Cargos em Comissão e das } \\
\text { Funções Gratificadas do Ministério da Saúde }\end{array}$ & $\begin{array}{l}\text { Decretos nos } 4.726 \text {, de } 9 \text { de junho de } \\
2003 \text {, e } 4.907 \text {, de } 3 \text { de dezembro de } \\
2003\end{array}$ \\
\hline $13 / 07 / 2006$ & 5.841 & $\begin{array}{l}\text { Aprova a Estrutura Regimental e o Quadro } \\
\text { Demonstrativo dos Cargos em Comissão e das } \\
\text { Funções Gratificadas do Ministério da Saúde }\end{array}$ & $\begin{array}{l}\text { Decreto no 5.678, de } 18 \text { de janeiro } \\
\text { de } 2006 \text {. }\end{array}$ \\
\hline $29 / 11 / 2006$ & 5.974 & $\begin{array}{l}\text { Aprova a Estrutura Regimental e o Quadro } \\
\text { Demonstrativo dos Cargos em Comissão e das } \\
\text { Funções Gratificadas do Ministério da Saúde }\end{array}$ & $\begin{array}{l}\text { Decreto no 5.841, de } 13 \text { de julho de } \\
2006\end{array}$ \\
\hline $27 / 05 / 2009$ & 6.860 & $\begin{array}{l}\text { Aprova a Estrutura Regimental e o Quadro } \\
\text { Demonstrativo dos Cargos em Comissão e das } \\
\text { Funções Gratificadas do Ministério da Saúde, } \\
\text { integra o Centro de Referência Professor Hélio } \\
\text { Fraga à estrutura da Fundação Oswaldo Cruz } \\
\text { FIOCRUZ, altera e acresce artigo ao Anexo Ie altera } \\
\text { o Anexo II ao Decreto no4.725, de } 9 \text { de junho de } \\
2003 \text {, que aprova o Estatuto e o Quadro } \\
\text { Demonstrativo dos Cargos em Comissão e das } \\
\text { Funções Gratificadas da FIOCRUZ }\end{array}$ & $\begin{array}{l}\text { Decreto no } 5.974, \text { de } 29 \text { de } \\
\text { novembro de } 2006 .\end{array}$ \\
\hline
\end{tabular}




\begin{tabular}{|c|c|c|c|}
\hline & & & \\
\hline $29 / 03 / 2010$ & 7.135 & $\begin{array}{l}\text { Dispõe sobre remanejamento de cargos em comissão } \\
\text { do Grupo de Direção e Assessoramento Superiores } \\
\text { DAS; aprova a Estrutura Regimental e o Quadro } \\
\text { Demonstrativo dos Cargos em Comissão e das } \\
\text { Funções Gratificadas do Ministério da Saúde; altera } \\
\text { o Anexo II ao Decreto no } 4.727 \text { de } 9 \text { de junho de } \\
2003 \text {, que trata do Estatuto e do Quadro } \\
\text { Demonstrativo dos Cargos em Comissão e das } \\
\text { Funções Gratificadas da Fundação Nacional de } \\
\text { Saúde; e dá outras providencias. }\end{array}$ & $\begin{array}{l}\text { art. } 1 \text {, os incisos I e II do art. } 20 \text {, os } \\
\text { arts. } 3^{\circ} \text { e } 4^{\circ} \text { e os Anexos I e II ao } \\
\text { Decreto no } 6.860 \text {, de } 27 \text { de maio de } \\
2009 .\end{array}$ \\
\hline $06 / 05 / 2010$ & 7.171 & $\begin{array}{l}\text { Altera o Decreto no 4.725, de } 9 \text { de junho de 2003, } \\
\text { que aprova o Estatuto e o Quadro Demonstrativo dos } \\
\text { Cargos em Comissão e das Funções Gratificadas da } \\
\text { Fundação Oswaldo Cruz - FIOCRUZ, no tocante ao } \\
\text { Centro de Referência Professor Hélio Fraga }\end{array}$ & $\begin{array}{l}\text { alínea "o" do inciso VI do art. } 3^{\circ} \text { e o } \\
\text { art. } 30^{\mathrm{a}} \text { do Anexo I ao Decreto }{ }^{\circ} \\
4.725 \text {, de } 9 \text { de junho de } 2003 \text {; art. } 60 \\
\text { do Decreto no } 6.860 \text {, de } 27 \text { de maio } \\
\text { de } 2009 \text {, na parte em que acrescenta } \\
\text { a alínea "o" ao inciso VI do art } 3^{\circ} \text { do } \\
\text { Anexo I ao Decreto no } 4.725 \text {, de } 9 \\
\text { de junho de 2003; e arts. } 7^{\circ} \text { e } 8^{\circ} \text { do } \\
\text { Decreto n } 6.860 \text {, de } 27 \text { de maio de } \\
2009\end{array}$ \\
\hline $19 / 11 / 2010$ & 7.336 & $\begin{array}{l}\text { Aprova a Estrutura Regimental e o Quadro } \\
\text { Demonstrativo dos Cargos em Comissão e das } \\
\text { Funções Gratificadas do Ministério da Saúde }\end{array}$ & $\begin{array}{l}\text { Decreto no } 7.135 \text {, de } 29 \text { de março de } \\
2010\end{array}$ \\
\hline
\end{tabular}

Fonte: site do Palácio do Planalto (http://www.planalto.gov.br/ccivil - Acesso em 26 de abril de 2005) ${ }^{41}$

O site da Biblioteca Virtual em Saúde possui publicados os regimentos internos e organogramas básicos compilados pelo próprio ministério, contendo informação mais detalhada das atribuições de todas as suas secretarias e órgãos internos. Entretanto, não houve publicação similar para o ano de 2009, apenas para 2005 (criado a partir do decreto de junho de 2003), 2006 e 2010. Por essa razão, para compreender o período inicial será utilizado o primeiro decreto de 2003 em comparação com o último de 2010, a fim de verificar as alterações para o período todo. Olhando para os resultados, de maneira geral, as principais alterações dizem respeito aos órgãos singulares, mais especificamente à alteração no número de departamentos no interior de algumas secretarias ${ }^{42}$.

\footnotetext{
${ }^{41}$ Decreto ${ }^{\circ} 4.726$ de 9 de junho de 2003 disponível em: http://www.planalto.gov.br/ccivil_03/decreto/2003/D4726.htm/ Decreto $n^{\circ} 4.907$ de 3 de dezembrode2003 disponível em http://www.planalto.gov.br/ccivil 03/decreto/2003/D4907.htm/ Decreton $^{\circ} 5.678$ de 18 de janeiro de 2006 disponível em: http://www.planalto.gov.br/ccivil 03/_Ato20042006/2006/Decreto/D5678.htm/Decreton ${ }^{\circ} 5.841$ de 13 de julho de 2006 disponível em: http://www.planalto.gov.br/ccivil 03/_Ato20042006/2006/Decreto/D5841.htm /Decreto n 5.974 de 29 de novembro de 2006 disponível em: http://www.planalto.gov.br/ccivil_03/_Ato200420062006/Decreto/D5974.htm/ Decreto $\mathrm{n}^{\circ}$ 6.860, de 27 de maio de 2009 disponível em: hitp://www.planalto.gov.br/ccivil_03/_Ato20072010/2009/Decreto/D6860.htma\#anexoï/Decreton ${ }^{\circ} 7.135$, de 29 de março de 2010 disponível em: http://www.planalto.gov.br/ccivil 03/ Ato20072010/2010/Decreto/D7135.htw Decreto $\mathrm{n}^{\circ} 7.171$ de 06 de maio de 2010 disponível em: hitp://www.planalto.gov.br/ccivil_03/_Ato20072010/2010Decreto/D7171.htm\#art5/Decreton 7.336 de 19 denovembrode 2010 disponível em: http:/hww.planalto.gov.br/ccivil_03/_Ato20072010/2010/Decreto/D7336.htm
}

${ }^{42} \mathrm{Na}$ Secretaria de Atenção à Saúde, foram incluídos os Departamentos de Gestão Hospitalar no Estado do Rio de Janeiro; de Certificação de Entidades Beneficentes de Assistência Social em Saúde. Na Secretaria de Ciência, Tecnologia e Insumos Estratégicos, foi criado o Departamento do Complexo Industrial e Inovação em Saúde. Na Secretária de Vigilância houve a criação do Departamento de Vigilância, Prevenção 
Não obstante, quando se observa de modo mais detido as competências em política externa, foi possível perceber que o número de órgãos com tal prerrogativa permaneceu praticamente inalterado ${ }^{43}$, conforme demonstrado na tabela abaixo:

\begin{tabular}{|c|c|}
\hline \multicolumn{2}{|c|}{$\begin{array}{l}\text { Tabela 10. Competências em Política Externa dos Decretos presidenciais que autorizam a Estrutura } \\
\text { Regimental e Quadro Demonstrativo dos Cargos do Ministério da Saúde (2003 e 2010) }\end{array}$} \\
\hline 2003 & 2010 \\
\hline $\begin{array}{l}\text { Art. } 3^{\circ} \text { Ao Gabinete do Ministro compete: } \\
\text { V exercer as atividades de comunicação social, bem como de } \\
\text { relações internacionais relacionadas com a cooperação em } \\
\text { saúde, de interesse do Ministério; }\end{array}$ & $\begin{array}{l}\text { Art. 3o Ao Gabinete compete: } \\
\text { V exercer as atividades de comunicação social, bem como de } \\
\text { relações internacionais relacionadas com a cooperação em } \\
\text { saúde, de interesse do Ministério da Saúde; }\end{array}$ \\
\hline $\begin{array}{l}\text { Art. } 4^{\circ} \text { À Secretaria Executiva compete: } \\
\text { VII assessorar a direção dos órgãos do Ministério na } \\
\text { formulação de estratégias de colaboração com organismos } \\
\text { financeiros internacionais; }\end{array}$ & $\begin{array}{l}\text { Art. } 40 \text { À Secretaria Executiva compete: } \\
\text { VIII assessorar a direção dos órgãos do Ministério na } \\
\text { formulação de estratégias de colaboração com organismos } \\
\text { financeiros internacionais; }\end{array}$ \\
\hline $\begin{array}{l}\text { Art. 19. À Secretaria de Gestão do Trabalho e da Educação na } \\
\text { Saúde compete: } \\
\text { IX fomentar a cooperação internacional, inclusive mediante a } \\
\text { instituição a coordenação de fóruns de discussão, visando à } \\
\text { solução dos problemas relacionados à formação, ao } \\
\text { desenvolvimento profissional, à gestão e à regulação do } \\
\text { trabalho em saúde, especialmente as questões que envolvam os } \\
\text { países vizinhos do continente americano, os países de língua } \\
\text { portuguesa e os países do hemisfério sul. }\end{array}$ & $\begin{array}{l}\text { Art. 24. À Secretaria de Gestão do Trabalho e da Educação na } \\
\text { Saúde compete: } \\
\text { IX fomentar a cooperação internacional, inclusive mediante a } \\
\text { instituição e a coordenaçãa de fóruns de discussão, visando à } \\
\text { solução dos problemas relacionados à formação, ao } \\
\text { desenvolvimento profissional, à gestão e à regulação do } \\
\text { trabalho em saúde, especialmente as questões que envolvam os } \\
\text { países vizinhos do continente americano, os países de língua } \\
\text { portuguesa e os países do hemisfério sul. }\end{array}$ \\
\hline \multirow[t]{2}{*}{$\begin{array}{l}\text { Art. 29. À Secretaria de Vigilância em Saúde compete: } \\
\text { IX promover o intercâmbio técnico-científico, com organismos } \\
\text { governamentais e não-governamentais, de âmbito nacional e } \\
\text { internacional, na área de epidemiologia e controle de doenças; }\end{array}$} & $\begin{array}{l}\text { Art. 36. À Secretaria de Vigilância em Saúde compete: } \\
\text { IX promover o intercâmbio técnico-científico, com organismos } \\
\text { governamentais e não governamentais, de âmbito nacional e } \\
\text { internacional, na área de Vigilância em Saúde }\end{array}$ \\
\hline & $\begin{array}{l}\text { Art. 40. Ao Departamento de Vigilância, Prevenção e Controle } \\
\text { das Doenças Sexualmente Transmissíveis, } \\
\text { Síndrome da Imunodeficiência Adquirida e Hepatites Virais } \\
\text { compete: } \\
\text { IV prestar assessoria técnica e estabelecer cooperações } \\
\text { nacionais e internacionais. (este Departamento pertence à } \\
\text { Secretaria de Vigilância em Saúde) }\end{array}$ \\
\hline
\end{tabular}

Fonte: Ministério da Saúde, 2005; 2010b ${ }^{44}$.

e Controle das Doenças Sexualmente Transmissíveis, Síndrome da Imunodeficiência Adquirida e Hepatites Virais. Além disso, é importante destacar a criação da Secretaria Especial de Saúde Indígena. No âmbito das entidades vinculadas, a alteração encontrada foi a entrada da empresa pública de hemoderivados e biotecnologia. A única extinção, percebida no período, foi a do Departamento de Articulação e Acompanhamento da Reforma Sanitária, tarefa que ficou a cargo da Secretaria de Gestão Estratégica e Participativa.

${ }^{43}$ A única alteração foi a incorporação do Departamento de Vigilância, Prevenção e Controle das Doenças Sexualmente Transmissíveis, Síndrome da Imunodeficiência Adquirida e Hepatites Virais, pertencente à Secretaria de Vigilância em Saúde, para tratar de questões internacionais. Mas isso pode ser facilmente explicado pelo fato de que o decreto que aprovou a Estrutura Regimental em 2003, não contava com a presença deste Departamento.

44 Disponíveis no site da Biblioteca Virtual em (http://bvsms.saude.gov.br/bvs/publicacoes/regimentos_internos_organogramas_ministerio_saude.pdf e http://bvsms.saude.gov.br/bvs/publicacoes/regimentos_internos_organogramas_basicos_ms.pdf - Acesso em 30 de maio de 2006). 
Entretanto, tem-se um cenário bem diferente quando se compara a distribuição de competências em política externa entre os dois regimentos internos. A tabela seguinte demonstra que as secretarias que possuíam tal prerrogativa em 2003 continuaram a ter em $2010^{45}$, mas é expressiva a quantidade de órgãos no interior delas que se tornaram legalmente competentes para tratar também de assuntos internacionais:

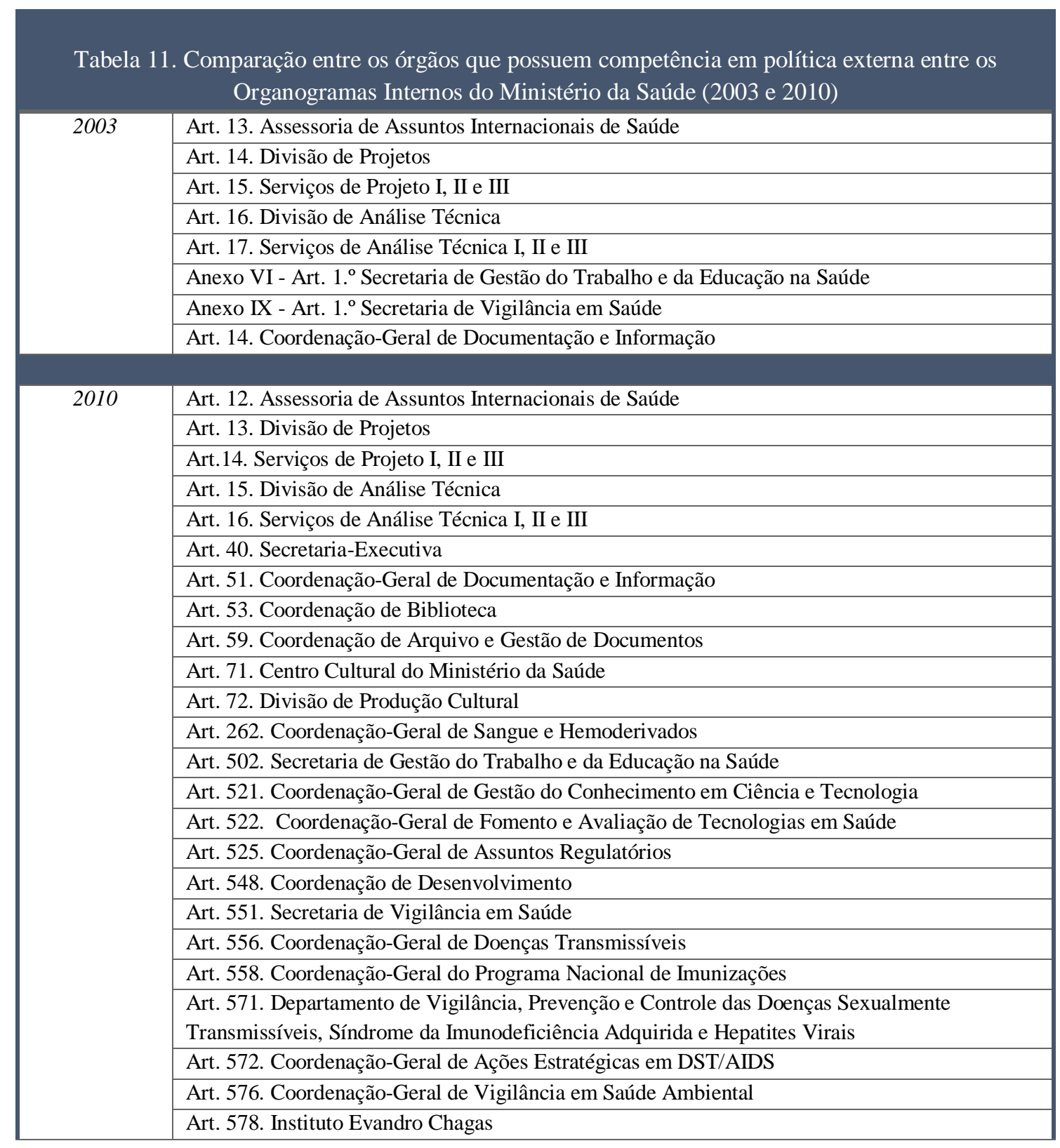

45 Mesmo a Coordenação-Geral de Documentação e Informação, que em 2010, aparece desmembrada em Coordenação-Geral de Documentação e Informação, Coordenação de Biblioteca, Coordenação de Arquivo e Gestão de Documentação. 
Art. 579. Serviço de Administração

Fonte: Ministério da Saúde, 2005; 2010.

Posto isso, agora comparando o decreto presidencial com o regimento interno, conclui-se que no ano de 2003, este último respeitou as competências atribuídas pelo primeiro ainda que em um nível formal - de onde conclui-se que o ministro Humberto Costa pouco lançou mão da discricionariedade posta à sua disposição para dotar suas secretarias de maior capacidade para tratar a temática. Isso porque dos oito órgãos com competência para atuar em política externa, descritos na tabela, cinco deles estavam reunidos no Gabinete do Ministro ${ }^{46}$, sendo que os constantes nos artigos 14, 15, 16 e 17 estão todos subordinados à Assessoria de Assuntos Internacionais (AISA). Como a CoordenaçãoGeral de Documentação e Informação pertence à Secretaria-Executiva, tem-se que apenas as outras duas secretarias, com funções muito específicas, ou seja, de caráter mais técnico, possuíam prerrogativa legal para tratar de assuntos internacionais.

Em 2010, entretanto, este quadro de total cumprimento sofreu algumas alterações. Como visto, todas as secretarias estabelecidas no decreto presidencial em 2003 como competentes para atuar em política externa foram mantidas ${ }^{47}$; e se neste último, apenas elas desempenhavam atividades internacionais, tal qual previsto pelo decreto, os dados recolhidos para 2010 apresentaram que, com exceção da Secretaria Especial de Saúde Indígena (SESAI), todas as outras sete secretarias do ministério (mais o Gabinete do Ministro) possuíam capacidade para tal; destacando-se a Secretaria de Vigilância em Saúde (SVS), conforme pode ser observado na figura síntese a seguir:

\footnotetext{
${ }^{46}$ Assessoria de Assuntos Internacionais de Saúde; Divisão de Projetos; Serviços de Projeto I, II e III; Divisão de Análise Técnica; Serviços de Análise Técnica I, II e III.

${ }^{47}$ Foi adicionada uma secretaria específica, que não existia naquele ano e aparece no organograma interno apresentando estas competências, a Secretaria de Ciência, Tecnologia e Insumos Estratégicos (SCTIE), através da Coordenação-Geral de Gestão do Conhecimento em Ciência e Tecnologia, Coordenação-Geral de Fomento e Avaliação de Tecnologias em Saúde, e da Coordenação-Geral de Assuntos Regulatórios, da Secretaria de Ciência, Tecnologia e Insumos Estratégicos Além destes casos, a Coordenação de Desenvolvimento, pertencente à Secretaria de Gestão Estratégica e Participativa, que mudou de nome e recebeu outras atribuições. Os demais órgãos que entraram são da Secretaria de Vigilância em Saúde.
} 
Figura 7. Unidades do Ministério da Saúde que possuíam competência em política externa em 2010 organizados por Secretarias

\section{Gabinete do Ministro}

- Assessoria de Assuntos Internacionais de Saúde

- Divisão de Projetos

- Serviços de Projeto I, II e III

- Divisão de Análise Técnica

- Serviços de Análise Técnica I, II e III

\section{Secretaria-Executiva - SE}

- Coordenação-Geral de Documentação e Informação

- Coordenação de Biblioteca

- Coordenação de Arquivo e Gestão de Documentos

- Centro Cultural do Ministério da Saúde

- Divisão de Produção Cultural

\section{Secretaria de Atenção à Saúde - SAS}

- Coordenação-Geral de Sangue e Hemoderivados

\section{Secretaria de Gestão do Trabalho e da Educação na Saúde - SGTES}

\section{Secretaria de Ciência, Tecnologia e Insumos Estratégicos - SCTIE}

- Coordenação-Geral de Gestão do Conhecimento em Ciência e Tecnologia

- Coordenação-Geral de Fomento e Avaliação de Tecnologias em Saúde

- Coordenação-Geral de Assuntos Regulatórios

\section{Secretaria de Gestão Estratégica e Participativa - SGEP}

- Coordenação de Desenvolvimento

\section{Secretaria de Vigilância em Saúde - SVS}

- Coordenação-Geral de Doenças Transmissíveis

- Coordenação-Geral do Programa Nacional de Imunizações

- Departamento de Vigilância, Prevenção e Controle das Doenças Sexualmente Transmissíveis, Síndrome da

Imunodeficiência Adquirida e Hepatites Virais

- Coordenação-Geral de Ações Estratégicas em DST/AIDS

- Coordenação-Geral de Vigilância em Saúde Ambiental

- Instituto Evandro Chagas

- Serviço de Administração

Fonte: Ministério da Saúde, 2005; $2010 b$.

A discrepância entre o previsto no decreto e o que é apresentado no regimento interno em 2010, é que o primeiro estabelecia que apenas três delas, além do GM (Secretaria Executiva, Secretaria de Gestão do Trabalho e da Educação na Saúde e a Secretaria de Vigilância em Saúde ${ }^{48}$ ), possuíam competências legais para atuar em política externa. É possível aventar duas possibilidades para este descompasso. Por um lado, ele pode ser resultado do esforço do ministério em organizar sua estrutura interna para garantir o

48 Na qual se inclui o Departamento de Vigilância, Prevenção e Controle das Doenças Sexualmente Transmissíveis, Síndrome da Imunodeficiência Adquirida e Hepatites Virais. 
cumprimento dos compromissos assumidos pelo governo brasileiro no que diz respeito à agenda de PEB adotada pelo presidente Lula, visto que as demandas tornaram-se cada vez maiores e em diferentes áreas; por outro pode significar que ele buscou aperfeiçoarse institucionalmente para ampliar ainda mais a sua participação no cenário internacional, utilizando-se do seu poder discricionário para garantir maior autonomia às suas secretarias para lidar diretamente com as questões correspondentes às suas respectivas competências e que eram de seu interesse direto. Outrossim, uma não exclui a outra, ao contrário, são antes duas estratégias complementares, e que, em última instância, permitiram que ao mesmo tempo em que o ministério consolidasse sua internacionalização, ele também se tornasse responsivo às diretrizes de governo estabelecidas pelo presidente.

Ainda em relação à primeira hipótese, os achados por um lado demonstram que o arranjo institucional do MS tornou-se mais complexo em relação aos assuntos internacionais, quando comparado ao ano de 2003, e por outro complementam e sugerem respostas às questões colocadas pelo trabalho realizado por Cepik e Sousa (2011), um dos mais importantes estudos que alia a PEB com a política externa implementada pelo MS.

No bojo da discussão teórica adotada pela dissertação e com o intuito de verificar a simetria entre as iniciativas de CT por parte do ministério e as diretrizes da PEB no início do primeiro mandato de Lula (primeiro semestre de 2003), os autores realizaram uma análise dos levantamentos preliminares a respeito da cooperação técnica que foi feita pela Assessoria Internacional do Ministério da Saúde (AISA-MS) e pela Diretoria de Investimento e Projetos Estratégicos (DIPE) da Secretaria-Executiva. Este levantamento dizia respeito às iniciativas de diferentes órgãos e agências do ministério com países ou organismos internacionais, esforço este do qual os autores fizeram parte.

Estes órgão e agências responderam a um questionário no qual era solicitado que eles indicassem cinco iniciativas internacionais mais importantes em andamento até junho de 2003, que foram enviadas pelos seguintes órgãos: a Assessoria Internacional do Ministério da Saúde (AISA-MS), o Programa de Doenças Sexualmente Transmissíveis (DST/AIDS), o Instituto Nacional do Câncer (INCA), a Fundação Nacional de Saúde (FUNASA), a Fundação Oswaldo Cruz (Fiocruz), a Agência Nacional de Saúde 
Suplementar (ANS) e a Agência Nacional de Vigilância Sanitária (ANVISA), que totalizavam vinte e nove programas e ações.

A conclusão a que eles chegaram é que as iniciativas de cooperação internacional quando comparadas às diretrizes de política externa do governo Lula, ainda que possuíssem algumas prioridades transversais, eram sensíveis a alguns desafios comuns a todas as áreas e órgãos do MS. O principal obstáculo com o qual o governo deparava-se, naquele momento, decorria muito mais da inércia institucional característica de períodos de transição presidencial e de dificuldades oriundas da tentativa de produzir pontos de encontro entre políticas públicas de setores diversos, do que aqueles relativos à implementação de uma nova ordem para a política externa. Isso explica-se, sobretudo, em função do fato de que ao longo dos anos subsequentes, as dificuldades estiveram associadas à formação de coalizões em que figuravam interesses contrários, além de elementos específicos da política ${ }^{49}$.

Além disso, eles apontaram para dificuldades no que dizia respeito ao orçamento, à organização e às práticas institucionais. Para que a política de CT obtivesse sucesso, seria necessária uma maior sinergia entre o MS e os demais ministérios, tais como o MRE, o da Ciência e Tecnologia, e o Desenvolvimento, Indústria e Comércio Exterior (MDIC), além de uma maior integração com os governos estaduais, municipais, empresas e sociedade civil. Como exemplo, eles levantaram o fato de que em 2009 já existiam mais de 150 ações de cooperação internacional em saúde, sendo que apenas em julho daquele ano, foi constituído um Grupo Temático de Cooperação Internacional em Cooperação Internacional em Saúde.

Cabe ressaltar que eles concluíram alertando para a carência apresentada em 2003 no que diz respeito à estrutura institucional mais capacitada para atuar na área internacional, não apenas em seus aspectos formais, mas também em relação à "garantia de um número adequado de técnicos e especialistas ou a continuidade administrativa nas áreas internacionais dos órgãos relevantes, mas também um esforço continuado de

\footnotetext{
${ }^{49}$ Conforme foi demonstrado na introdução deste trabalho e no capítulo 2, permanecia até o momento das entrevistas que foram realizadas para esta pesquisa, muitas dúvidas e incertezas entre os quadros dos Ministérios (MRE e MS), a respeito da gestão da CTPD, muito em razão de seu caráter inovador que requeria ainda ajustes para sua consecução.
} 
capacitação e planejamento conjunto de atividades. No caso dos países prioritários para a cooperação internacional na área de saúde, seria necessário estreitar os processos de discussão e treinamento conjunto das próprias equipes responsáveis pela condução das iniciativas, pois muitas iniciativas importantes para o Brasil esbarram nas dificuldades dos interlocutores e gestores dos outros países” (p. 126-127). Essa questão aparece em 2010 melhor desenvolvida.

Mas, apenas comprovar que em 2010, José Gomes Temporão, utilizando-se de seu poder discricionário, assinou o regimento interno autorizando um maior envolvimento das áreas técnicas do MS com a política externa, não equivale à afirmação de que as atividades de suas secretarias - quando tomadas em sua totalidade-, tenham adentrado por isso à esfera da política burocrática, tornando o ministério, por sua vez, um ator político atuando para além de seu papel de implementador. Isso porque, se por um lado, a agenda presidencial passou a englobar cada vez mais ações internacionais de caráter técnico, entende-se que a estrutura do MS como um todo, deveria responder a este novo fluxo, como ocorre frequentemente com as políticas domésticas. Agora, empreender uma leitura das competências atribuídas a essas secretarias, utilizando como referencial teórico o ciclo das políticas públicas a partir de um plano concreto específico, possibilita responder se o ministério foi ou não, no período analisado, também um formulador de política externa, movendo-se autonomamente a partir da delegação presidencial.

Este, entretanto, é um problema que corresponde a três níveis distintos de análise, sendo o primeiro deles a observação da atenção presidencial dedicada ao Haiti, concentrando a maior parte das decisões a esse respeito na figura do presidente; o segundo, relativo ao momento da delegação ao MS para tratar da questão e o terceiro, o grau de autonomia conferido ao MS para organizar sua estrutura institucional para atuar também na arena política. A próxima e última seção do trabalho buscará justamente verificar, a partir do estudo de caso do Projeto Sul-Sul de Fortalecimento da Autoridade Sanitária do HaitiPRODOC-BRA/10/2005, assinado em 29 de novembro de 2010, três principais pontos que perpassam este questionamento: i) a presença ativa do ex-presidente Lula na consecução da CTPD realizada pelo MS no Haiti; ii) a delegação de poderes ao ministério a partir das decisões tomadas no interior do Gabinete de Crise instaurado após o terremoto de 2010 e iii) como o MS, a partir de seu poder discricionário mobilizou as competências 
de secretarias específicas para a consecução do projeto, trazendo para a arena decisória sua consolidada expertise.

\section{A Cooperação Técnica do Ministério da Saúde no Haiti: Um Estudo de Caso do Projeto Sul-Sul de Fortalecimento da Autoridade Sanitária do Haiti - PRODOC- BRA/10/2005}

Muito tem sido discutido sobre as dificuldades que o sistema de saúde haitiano encontra em fomentar políticas públicas capazes de atender sua população, um problema intimamente relacionado à permanência de precárias condições de pobreza e marginalização que o coloca na posição de país mais pobre das Américas. No que tange à saúde, o 2005 - 2011: National Strategic Plan for Health Sector Reform, publicado pela OMS em novembro de 2005, mostrou que o acesso à saúde básica era inadequado ao pontuar que menos de $40 \%$ da população possuía acesso aos serviços básicos em algumas localidades, obrigando que $80 \%$ dos haitianos recorressem à medicina tradicional local para o tratamento das enfermidades. Ainda de acordo com o relatório:

"For many Haitians, the need to pay before receiving treatment precludes their getting any health care. Some organizations are promoting the idea of offering free services to increase access to treatment. Health costs (consultations, hospitalization, medical care, and drug purchases), too, have risen precipitously and can no longer be borne by people of limited means. Forty-seven percent of the population lacks access to basic health care; 50\% lacks access to basic drugs. A medical consultation that cost 25 Haitian Gourdes (HTG) in the late 1980s now costs 1,200 HTG-48 times more”(OMS, 2007).

Ainda que parciais - devido à extensão do relatório -, estas informações demonstram que a saúde naquele país apresentava carências graves ainda no período anterior ao terremoto e, por essa razão, necessitava com urgência de atenção da comunidade internacional. Com a entrada do Brasil na MINUSTAH, estes desafios tornaram-se parte integrante da forçatarefa empreendida pelo governo para auxiliar na estabilidade social do país, uma vez que no Comunicado Conjunto assinado pelo presidente Lula e pelo presidente haitiano Boniface Alexandre, em 18 de agosto de 2004, a saúde aparecia entre as áreas contempladas para receber uma missão de avaliação com o intuito de iniciarem-se os projetos de cooperação técnica. 
Os poucos trabalhos teóricos sobre a CTPD realizada pelo MS no Haiti, entretanto, possuem como marco temporal a assinatura do Memorando de Entendimento BrasilCuba-Haiti para o fortalecimento do sistema e dos serviços públicos de saúde e de vigilância epidemiológica no Haiti, em março de 2010, ou seja, no período pós-terremoto (Pessôa et al., 2013; Misoczky et al., 2015; Gomes e Oliveira, 2015); dentre eles, alguns chegam a apontar que anteriormente ao desastre, o MS não realizava atividades de cooperação naquele país (Misoczky, 2015; Goulart e da Costa, 2015). Porém, de acordo com o Ministério do Planejamento ${ }^{50}$, o MS informou em 2010 que:

"O Ministério da Saúde do Brasil considera o Projeto de Cooperação em Saúde BrasilHaiti como uma de suas prioridades na área internacional. Esta cooperação situa-se em dois modelos: cooperação bilateral, a qual já vinha em andamento, como por exemplo, o Projeto do Banco de Leite, e outras ações que surgiram após o terremoto de 12 de janeiro de 2010, o que reforçou a atuação deste Ministério em ações bilaterais de reestruturação e multilaterais" (p. 34).

Além disso, estão registradas as assinaturas de três Ajustes Complementares e uma Declaração de Intenção no período anterior ao terremoto ${ }^{51}$. A listagem de atos internacionais celebrados antes de 2010 é demonstrada na tabela seguinte:

\begin{tabular}{|c|c|c|c|c|c|}
\hline $\begin{array}{l}\text { Tipo de } \\
\text { Acordo }\end{array}$ & Natureza & Projeto & Data & Autoridade Brasileira & Função \\
\hline $\begin{array}{c}\text { Triangular } \\
\text { Brasil- } \\
\text { Canadá- } \\
\text { Haiti }\end{array}$ & $\begin{array}{c}\text { Ajuste } \\
\text { Complementar }\end{array}$ & $\begin{array}{l}\text { Aprimoramento do Programa } \\
\text { Haitiano de Imunizações }\end{array}$ & $23 / 05 / 2006$ & Celso Amorim & $\begin{array}{l}\text { Ministro das } \\
\text { Relações } \\
\text { Exteriores }\end{array}$ \\
\hline Bilateral & $\begin{array}{c}\text { Ajuste } \\
\text { Complementar }\end{array}$ & $\begin{array}{l}\text { Aprimoramento do Programa } \\
\text { Haitiano de Imunizações }\end{array}$ & $23 / 05 / 2006$ & Celso Amorim & $\begin{array}{l}\text { Ministro das } \\
\text { Relações } \\
\text { Exteriores }\end{array}$ \\
\hline $\begin{array}{c}\text { Triangular } \\
\text { Brasil - } \\
\text { UNFPA- } \\
\text { OXFAM }\end{array}$ & $\begin{array}{c}\text { Ajuste } \\
\text { Complementar }\end{array}$ & $\begin{array}{c}\text { Combate à Violência contra } \\
\text { as Mulheres }\end{array}$ & $28 / 05 / 2008$ & Celso Amorim & $\begin{array}{c}\text { Ministro das } \\
\text { Relações } \\
\text { Exteriores }\end{array}$ \\
\hline
\end{tabular}

\footnotetext{
${ }^{50}$ Interface Ministério da Saúde - Sub-eixo: Política Externa (e) Cooperação Internacional. Disponível em:https://i3gov.planejamento.gov.br/balanco/4\%20\%20INSERCAO\%20NO\%20CENARIO\%20MUNDA \%20E\%20SOBERANIA/1\%20\%20Politica\%20externa/f\%20\%20Cooperacao\%20Inter\%20Seg\%20Alimn \%20e\%20Assistencia\%20Humanitaria/MS interface Coopera\%E7\%E3o\%20Internacional.doc (Acesso em 05 de junho de 2016).

${ }^{51}$ Um problema de desencontro e/ou carência de informações a respeito da CTPD ocorre com o Projeto para o Fortalecimento das Atividades de Controle da Raiva Humana Transmitida por cães no Haiti, para o qual não foi encontrado registro oficial da assinatura de acordo, tampouco no site da $\mathrm{ABC}$ na listagem de projetos executados, mas que, no entanto, aparece no relatório da AISA como sendo iniciado no ano de 2009 (AISA/MS, 2009).
} 


\begin{tabular}{|c|c|c|c|c|c|}
\hline $\begin{array}{c}\text { Triangular } \\
\text { Brasil- } \\
\text { França-Haiti }\end{array}$ & $\begin{array}{c}\text { Declaração de } \\
\text { Intenções }\end{array}$ & $\begin{array}{c}\text { Apoio à Implantação e } \\
\text { Implementação de Banco de } \\
\text { Leite Humano no Haiti }\end{array}$ & $18 / 09 / 2009$ & Celso Amorim & $\begin{array}{c}\text { Ministro das } \\
\text { Relações } \\
\text { Exteriores }\end{array}$ \\
\hline
\end{tabular}

Fonte: Sistema Consular Integrado - Sistema de Atos Internacionais (SCI). Disponível em: http://daimre.serpro.gov.br/ (Acesso em 04 de novembro de 2014)

De fato, o MS não era proeminente na CT com o Haiti no período anterior ao terremoto, quando destacaram-se os projetos de agricultura e segurança alimentar e nutricional, que dialogavam mais de perto com a agenda de combate à fome, uma das agendas prioritárias estabelecida pelo presidente Lula. Dados do projeto Promoção de ações de fortalecimento da agricultura familiar e da segurança alimentar e nutricional no Haiti, coordenado pelo Ministério do Desenvolvimento Social (MDS), apontam para o fato de que existiam aproximadamente 2,5 milhões de pessoas em situação de insegurança alimentar no país em 2008. O projeto previa então, a adoção de programas e ações de parte do governo haitiano que fossem capazes de retomar a produção agrícola nacional e diminuir, consequentemente, os índices de insegurança alimentar e nutricional, o que incluía uma estratégia intersetorial da área agrícola, segurança alimentar e nutricional, aliadas à promoção e proteção social. Deste modo, a questão nutricional e de mortalidade estavam relacionadas às competências próprias ao MS (Documento de Projeto - Cooperação Técnica entre Países em Desenvolvimento: Brasil-Haiti) ${ }^{52}$.

Uma das primeiras iniciativas do MS brasileiro no intuito de reduzir a mortalidade de recém-nascidos foi a implementação do Banco de Leite Humano ${ }^{53}$, que, não obstante, foi precedida por outros três projetos em diferentes áreas, seguidos de uma atividade isolada, conforme demonstrado a seguir:

\footnotetext{
${ }^{52}$ Documento disponível em: http://mds.gov.br/acesso-a-informacao/institucional/internacional/projetosde-cooperacao-tecnica-e-financeira-com-organismos-internacionais (Acesso em 15 de outubro de 2014).

${ }^{53}$ Este projeto foi realizado em triangulação com a França sob a coordenação da Fiocruz mas não foi localizado o respectivo registro no sistema integrado de atos internacionais do MRE, de modo que a existência de uma Declaração de Intenções entre os dois países foi citada no site da própria Fiocruz através do

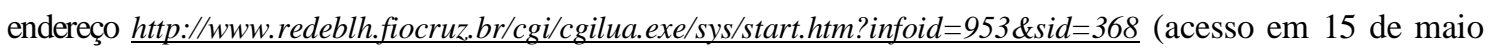
de 2016).
} 
Figura 8. Listagem dos projetos de CTPD desenvolvidos pelo Ministério da Saúde entre Brasil e Haiti (2006-2009)

\begin{tabular}{l}
\hline 2006 \\
• Aprimoramento do Programa Haitiano de Imunizações - Triangulação com o Canadá \\
(CIDA) \\
\hline S/D \\
• Projeto de Cooperação Técnica (TCC) Brasil - Haiti para o Fortalecimento das \\
Atividades de Controle da Raiva Humana Transmitida por cães no Haiti \\
\hline 2008 \\
• Enfrentando à Violência Contra as Mulheres no Haiti (triangulação com a UNFPA e a \\
OXFAM) \\
\hline 2009 \\
• Apoio à Implantação do Banco de Leite Humano no Haiti (triangulação com a França - \\
AFD) \\
S/D \\
• Atividade Isolada em Intercâmbio de Experiências em Prevenção e Controle de Dengue \\
\hline
\end{tabular}

Fonte: site da ABC. Disponível em: http://www.abc.gov.br/ (Acesso em 10 de outubro de 2014).

A partir de 2010, entretanto, grande destaque passou a ser conferido à cooperação realizada com o Haiti, impulsionada pelo Memorando de Entendimento ${ }^{54}$, assinado pelo ministro José Gomes Temporão cujo objetivo era o de fortalecer os serviços de saúde pública haitiano. Após ele, foram assinados ainda cinco Ajustes Complementares que possibilitaram em conjunto, a elaboração e implementação de projetos de cooperação em saúde.

\begin{tabular}{|c|c|l|c|c|c|}
\hline \multicolumn{8}{|c|}{ Tabela 13. Atos Internacionais para o desenvolvimento de cooperação técnica pelo Ministério da } \\
Saúde entre Brasil e Haiti (2010)
\end{tabular}

\footnotetext{
${ }^{54}$ Este Memorando não consta no Sistema de Atos Internacionais (SCI) do MRE, tendo sido disponibilizada pela Secretaria-Executiva do Ministério da Saúde, cópia digital para o e-mail da autora.
} 


\begin{tabular}{|c|c|l|l|l|l|}
\hline & Ajuste & $\begin{array}{l}\text { Capacitação, Modernização e } \\
\text { Ampliação da Capacidade } \\
\text { Operacional do Laboratório } \\
\text { do Centro de Saúde } \\
\text { LuceliaBontemps, em La } \\
\text { Plaine - Haiti }\end{array}$ & 29/09/2010 & Celso Amorim & $\begin{array}{c}\text { Ministro das } \\
\text { Relações } \\
\text { Exteriores }\end{array}$ \\
\hline- & $\begin{array}{l}\text { Ajuste } \\
\text { Complementar }\end{array}$ & $\begin{array}{l}\text { Instituto Haiti-Brasil de } \\
\text { Reabilitação de Pessoas com } \\
\text { Deficiência }\end{array}$ & 29/09/2010 & Celso Amorim & $\begin{array}{c}\text { Ministro das } \\
\text { Relações } \\
\text { Exteriores }\end{array}$ \\
\hline
\end{tabular}

Fonte: Sistema Consular Integrado - Sistema de Atos Internacionais (SCI). Disponível em: http://daimre.serpro.gov.br/ (Acesso em 04 de novembro de 2014).

Os Ajustes constantes na tabela foram todos complementares ao Memorando de Entendimento de 27 de março de 2010, embora este último também seja reconhecido como complementar a um Acordo-Quadro. Mas ele foi o primeiro passo para a formalização do desenvolvimento maçico de projetos de CT estruturantes, aos moldes privilegiados pela $\mathrm{ABC}$, ainda que trouxesse em seu bojo atividades de cooperação humanitária, como a doação de medicamentos e o envio de profissionais da saúde brasileiros. Seu Artigo I estabelecia que seu objetivo era o de conjugar esforços para viabilizar projetos específicos para recuperação da infraestrutura e capacitação de profissionais da área da saúde, por meio da divisão de tarefas entre os governos brasileiro, haitiano e cubano (Memorando de Entendimento para o Fortalecimento do Sistema e dos Serviços Públicos de Saúde e de Vigilância Epidemiológica no Haiti) ${ }^{55}$.

A escolha na triangulação com Cuba, por sua vez, ocorreu por três principais razões: i) as reconhecidas experiência e técnica que o país possui na área da saúde; ii) o partilhamento da mesma concepção do governo brasileiro em relação à universalidade dos sistemas de saúde, e iii) o fato de Cuba estar presente desde 1998 no Haiti, desenvolvendo atividades de atenção à saúde, quando da ocorrência do furacão George. Assim, seu Artigo 3 determina que os projetos decorrentes do acordo deveriam ser coordenados por um Comitê Gestor Tripartite (CGT), constituído por um representante do Ministério da Saúde de cada um dos países envolvidos (Misoczky et al., 2015).

Não obstante, resultaram deste Memorando dez projetos que compõem um esforço maior concentrado no Projeto Sul-Sul de Fortalecimento da Autoridade Sanitária do Haiti PRODOC-BRA/10/2005, assinado em 29 de novembro de 2010 em conjunto com o Programa das Nações Unidas para o Desenvolvimento (PNUD), e que englobou os demais. Foram eles:

\footnotetext{
${ }^{55}$ O Memorando foi disponibilizado pela Secretaria-Executiva do Ministério da Saúde.
} 
Figura 9. Listagem dos projetos de CTPD desenvolvidos pelo Ministério da Saúde entre Brasil e Haiti (2010)

\section{$13 / 05 / 2010$}

- Apoio às Iniciativas de Proteção à Criança no Haiti - Pastoral da Criança - Fase 1

\section{$05 / 08 / 2010$}

- Programa de Cooperação Brasil-Haiti Pós-Terremoto: Inclusão Social de Pessoas com Deficiência

\section{$17 / 09 / 2010$}

- Apoio às Iniciativas de Proteção da Criança no Haiti - Pastoral da criança - Fase 2

\section{$28 / 10 / 2010$}

- Capacitação de Profissionais de Saúde Haitianos em Técnicas de Tratamento e Prevenção do Cólera

\section{$01 / 11 / 2010$}

- Programa de Capacitação em Reabilitação de Pessoas com Deficiência

\section{$05 / 11 / 2010$}

- Instituto Haiti - Brasil de Reabilitação de Pessoas com Deficiência

\section{$23 / 11 / 2010$}

- Treinamento de Profissionais de Saúde Haitianos em Técnicas de Tratamento e Prevenção do Cólera - Fase II

\section{9/11/2010}

- Projeto de Cooperação Sul-Sul de Fortalecimento da Autoridade Sanitária do Haiti

\section{$02 / 12 / 2010$}

- Apoio à Implantação e Implementação de Banco de Leite Humano no Haiti $15 / 12 / 2010$

- Fortalecimento da Capacidade Política e Institucional de Agentes Governamentais e Não-governamentais do Haiti para Promoção e Defesa dos Direitos das Pessoas com Deficiência

Fonte: site da ABC. Disponível em: http://www.abc.gov.br/ (Acesso em 10 de outubro de 2014).

O PRODOC - BRA/10/005 apontava para os baixos indicadores de saúde no país, demonstrados através dos elevados coeficientes de mortalidade materna e infantil; desnutrição e a alta prevalência de doenças infecto-contagiosas. Além disso, assinalava que após o terremoto, $60 \%$ dos hospitais haviam sido danificados ou completamente destruídos, além dos prédios e unidades que faziam parte do Sistema de Saúde Haitiano.

Como resposta, foram contempladas três frentes de ação selecionadas a partir das demandas de urgência do governo haitiano: a) investimento em infraestrutura (hospitais, ambulâncias, equipamentos, etc.); b) treinamento e capacitação de recursos humanos (formação de agentes comunitários de saúde e técnicos de nível médio) e c) vigilância epidemiológica e imunização. Esta mobilização de diferentes áreas da saúde evidencia o 
caráter multidisciplinar que do lado brasileiro envolveu além de diferentes Ministérios e instituições parceiras, uma multiplicidade de secretarias do MS para sua consecução.

Esclarecido o escopo do projeto, na sequência será empreendida uma leitura analítica do processo correspondente à sua consecução, desde a definição do agenda-setting presidencial pró-Haiti após o terremoto, culminando no trabalho empreendido pelas secretarias do ministério, que trouxeram para a arena decisória sua consolidada expertise.

\subsection{O Papel do ex-Presidente Lula}

Conforme foi analisado no capítulo 1, Rosati (1981) atribui relevada importância ao papel desempenhado pelo presidente no que diz respeito ao nível de atenção que ele deposita em determinada questão a ser decidida, um fator crítico para a estrutura do processo de tomada de decisão. Decorre disso três possibilidades que, em última instância, são responsáveis por definir a existência ou não de conflitos intra-burocráticos, quais sejam, os Domínios Presidencial, Burocrático e Local ${ }^{56}$.

Também foi demonstrado anteriormente que a escolha técnica, segundo a qual, de acordo com o presidente Lula, baseou-se a nomeação de Temporão para a pasta da saúde - e constituiu-se como um mecanismo de controle ex ante - possibilitou ao Ministério alcançar em 2010 elevado grau de discricionariedade quanto à agenda de política externa, mais que dobrando a quantidade de unidades de suas respectivas secretarias com competência para atuarem em pautas internacionais quando comparado a 2003.

Obviamente que o modo assertivo da atuação do presidente Lula na questão haitiana, desde o envolvimento brasileiro com a MINUSTAH e a relação que se estabeleceu com seus ministérios responsáveis pela implementação da cooperação técnica naquele país, foi um dos elementos-chave para que o Haiti recebesse durante praticamente todo o período de seus dois mandatos, um lugar privilegiado em sua agenda de governo, tanto que, no período de realização das entrevistas para este trabalho, já no governo de Dilma

\footnotetext{
${ }^{56}$ Para definição de cada um deles, ver capítulo 1.
} 
Rousseff, tanto o MRE quanto o MS reconheciam o menor envolvimento brasileiro com o Haiti, obtendo espaço apenas a continuidade dos projetos na área de saúde.

Deste modo, empregando o modelo proposto por Rosati (1981), é possível verificar a ocorrência de um Domínio Local, posto que a gestão de Temporão, além de privilegiar o aumento do escopo das relações internacionais do ministério, muito em função de sua consolidada trajetória em organismos internacionais, também buscava seguir o plano de governo estabelecido por Lula, como ficou evidenciado pelo discurso de posse do então ministro.

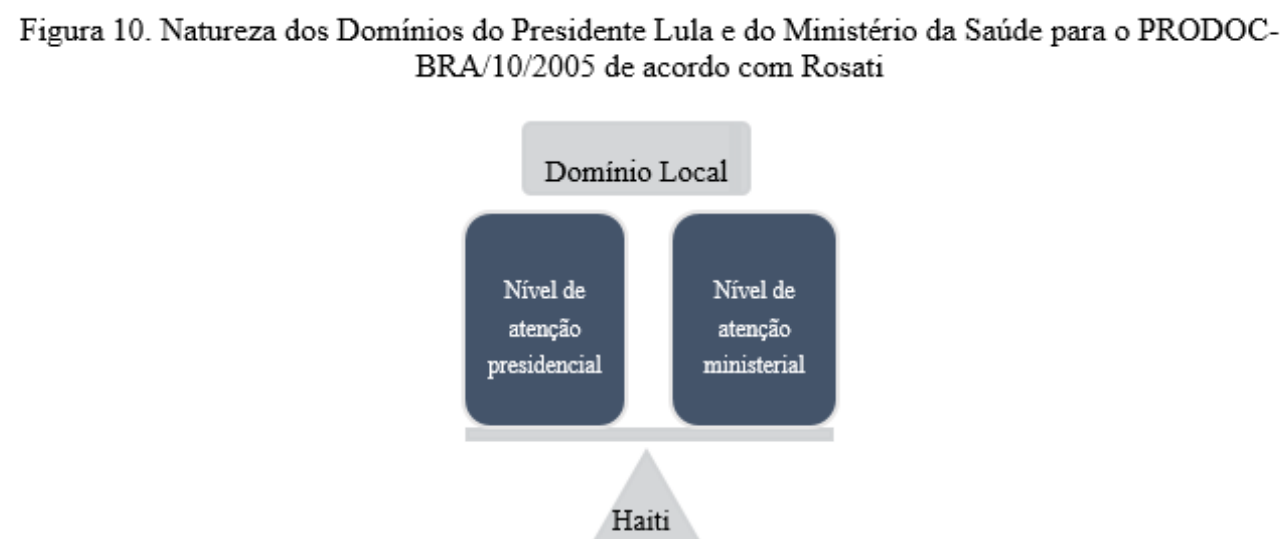

Fonte: Adaptado de Rosati, 1981.

Com enfoque para 2010, isso pode ser observado quando na primeira reunião ministerial do presidente Lula realizada no dia 21 de janeiro em Brasília, ele tratou o terremoto no Haiti como uma questão de prioridade; ocasião em que os então ministros da Defesa, Nelson Jobim, do Gabinete de Segurança Institucional, Jorge Félix e o secretário-geral do Itamaraty, Antônio Patriota, relataram a todos os presentes os trabalhos que vinham sendo realizados pela MINUSTAH, bem como as condições de vida na cidade de Porto Príncipe.

Lula anunciou então que enviaria uma mensagem de urgência ao Congresso Nacional solicitando autorização para o envio de novo contingente militar ao Haiti, bem como a edição de uma Medida Provisória para a liberação de R\$ 375 milhões para a realização de ações, incluindo US\$ 15 milhões que seriam doados pelo país. Deste montante, $\mathrm{R} \$$ 205 milhões seriam repassados ao Ministério da Defesa, R\$ 35 milhões, para o MRE e 
R\$ 135 milhões para o MS. Neste feito, ele determinou ao ministro Temporão que fossem instaladas dez Unidades de Pronto-Atendimento de Saúde (UPAS) no Haiti ${ }^{57}$.

Entretanto, é imprescindível ressaltar que essas medidas tão somente foram tomadas pelo presidente Lula mediante avaliações técnicas realizadas pelo próprio MS logo após a ocorrência do terremoto, e que foram resultado das decisões tomadas no interior do Gabinete de Gerenciamento de Crise instaurado pelo presidente e do qual o ministério fazia parte; o qual será visto na sequência.

\subsection{O Gabinete de Gerenciamento de Crise}

$\mathrm{Na}$ mesma noite em que ocorreu o terremoto em 12 de janeiro de 2010, o Centro de Comunicação Social do Exército (CComSEx), órgão central do Sistema de Comunicação Social do Exército Brasileiro, no Haiti, enviou as informações ao Brasil, a partir das quais decidiu-se pela criação de um Gabinete de Gerenciamento de Crise, coordenado pelo Gabinete de Segurança Institucional (GSI), que foi responsabilizado pela organização da assistência humanitária que seria a partir dali, prestada àquele país. Integravam esse comitê, os Ministérios da Saúde, da Defesa, das Relações Exteriores, do Planejamento e da Defesa Civil, além da Casa Civil da Presidência da República (Agostinho, 2011).

As discussões ocorridas no interior desse Gabinete definiram as prioridades a serem tomadas para prestar um socorro imediato ao Haiti na área da saúde, como o envio de medicamentos e profissionais para atuar no hospital de campanha do exército brasileiro, sendo que em reunião ocorrida no dia 19 de janeiro, foi determinado que o MS deveria enviar uma missão de avaliação do risco epidemiológico ${ }^{58}$.

\footnotetext{
${ }^{57}$ Informações disponíveis em: http://internacional.estadao.com.br/noticias/geral,por-mp-lula-libera-r375-mi-para-acoes-brasileiras-no-haiti,499380 e http://wwwl.folha.uol.com.br/poder/2010/01/682738em-reuniao-ministerial-lula-determina-edicao-de-mp-para-liberar-r-375-mi-ao-haitishtml_(Acesso em 27 de junho de 2016).

${ }^{58}$ Notas à imprensa publicadas pelo Gabinete de Gerenciamento de Crise para o Haiti no dia 14 de janeiro de 2010 e 19 de janeiro de 2010. Disponíveis em: http://www.gsi.gov.br/.arquivos/nota_14012010.pdf e http://www.gsi.gov.br/.arquivos/nota_19012010.pdf (Acesso em 27 de junho de 2016).
} 
A partir destes encontros, ainda em janeiro de 2010, o coordenador de Vigilância em Saúde Ambiental e Saúde do Trabalhador do MS, Guilherme Franco Netto, visitou o Haiti a fim de avaliar inicialmente a situação da saúde, bem como a capacidade de atendimento no local para subsidiar a atuação e o consequente apoio do ministério, o que resultaria na instituição de um Grupo de Trabalho (GT) do interior do ministério, a partir da edição da Portaria GM n 151 , de 15 de janeiro de $2010^{59}$ para deliberar sobre as iniciativas a serem empregadas no auxílio àquele país.

O documento elaborado a partir da instituição deste GT foi chamado Plano de Auxílio à Reestruturação do Sistema de Saúde do Haiti, que incluía, entre outras ações, a construção de dez UPAS, além da aquisição de 50 ambulâncias do Serviço de Atendimento Móvel de Urgência (Samu); a organização da atenção básica que possibilitasse o atendimento de $80 \%$ dos agravos de saúde; a estruturação do programa de Saúde da Família, e o reforço para a Pastoral da Criança (Ministério da Saúde, 2011). Foi justamente este o plano técnico que embasou as deliberações de Lula apresentadas à sua equipe na reunião ministerial de 21 de janeiro, somente após a qual, foram então anunciadas publicamente por Temporão ${ }^{60}$.

Após o anúncio das medidas, no dia 27 de março, o ministro visitou o Haiti para avaliar a situação e conhecer as instalações do Hospital de Campanha da Força Aérea Brasileira, que funcionava desde janeiro ${ }^{61}$. Naquele mesmo dia, ele assinou o Memorando de Entendimento Brasil-Cuba-Haiti, que foi o documento responsável pelo início da maciça cooperação em saúde naquele país.

O que se pode observar desse encadeamento de acontecimentos que culminaram na assinatura do Memorando e posterior elaboração e implementação de projetos? No que se refere ao processo decisório dois pontos merecem atenção: i) o poder burocrático do

\footnotetext{
${ }^{59}$ Disponível em: http://bvsms.saude.gov.br/bvs/saudelegis/gm/2010/prt0151_15_01_2010.html (Acesso em 28 de junho de 2016).

${ }^{60}$ Ele declarou publicamente em entrevista ao programa de rádio "Bom dia, Ministro", que foi ao ar em 28 de janeiro de 2010. Informação disponível em: http://noticias.uol.com.br/ultimasnoticias/terremoto-haiti/2010/01/28/28brasil-vai-ajudar-haiti-a-reestruturar-sistema-de saude-ditemporao.htm (Acesso em 27 de junho de 2016).

${ }^{61}$ Informação disponível em: http://fab.mil.br/noticias/mostra/5032/Ministro-da-Sa\%C3\%BAde-visitainstala\%C3\%A7\%C3\%B5es-do-Hospital-de-Campanha-no-Haiti (Acesso em 27 de junho de 2016).
} 
MS exercido pela detenção de uma tecnicidade, refletido, por sua vez, pela sua capacidade em formular propostas para políticas emergências e estruturantes no Haiti, tarefa esta, realizada a partir de visitas técnicas coordenadas não pela AISA ou pela SecretariaExecutiva, mas pelo coordenador de uma unidade do Departamento de Vigilância em Saúde Ambiental e Saúde do Trabalhador, pertencente à Secretaria de Vigilância e Saúde; e ii) a mobilização de sua estrutura institucional para lidar com a questão, que em última instância resultou da delegação principal-agente. Em relação ao primeiro aspecto, a discussão acerca da impossibilidade do presidente em lidar com todas as informações nas quais se baseiam as políticas públicas a fim de solucionar determinado problema torna-se evidente. A segunda por sua vez, apenas será discutida no item seguinte.

Antes de tratar desta questão, entretanto, cabe ressaltar que este exemplo possui um caráter extremamente particular, por tratar-se de decisões tomadas em um momento muito específico de uma tragédia humanitária de grandes proporções, quando se exige maior rapidez e eficiência por parte do governo para solucionar os problemas, sobretudo em um país com o qual o Brasil mantinha íntimas relações desde 2004. E visto que, o departamento supramencionado chamado por Temporão para realizar a visita de reconhecimento do Haiti, possui uma coordenação em particular, a Coordenação-Geral de Vigilância em Saúde Ambiental (CGVAM), que possui como foco a atuação em desastres, é compreensível que tenha sido nomeada a coordenadora dos trabalhos.

Não obstante, ele ilustra com muita clareza dois elementos importantes para a discussão, um que diz respeito à característica intrínseca da CTPD com o Haiti, via de regra, erigida a partir de acontecimentos-chave, ora por ocasião da MINSTAH ora pelo terremoto; e outro, como uma possibilidade de ilustrar o processo de definição de políticas intraExecutivo, elevando o papel exercido pelos Ministérios para a formulação destas a partir da necessidade do emprego de suas respectivas competências técnicas.

Desde que ocorreu o terremoto (12 de janeiro), quando foi instituído o Gabinete de Gerenciamento de Crise, até a elaboração de um plano de ação de emergência pelo MS, que contou ainda para tal, com a viagem de um de seus representantes ao Haiti, passaramse apenas três dias, e do dia 15 até o dia 21 (data da primeira reunião ministerial), apenas mais seis, ou seja, em menos de um mês, respondendo à demanda prioritária da agenda 
de política externa do presidente Lula, Temporão consolidou uma força-tarefa de seu ministério naquele país, a fim de responder a contento ao que lhe era solicitado.

Além disso, um outro aspecto muito importante, é que o fato exemplifica ao que a literatura se refere quando diz que as decisões políticas não são normalmente tomadas em condições rotineiras, - em que pese a ausência de elementos técnicos e de tempo para considerar uma multiplicidade de alternativas para uma questão em particular - o que faz com o presidente delegue aos demais agentes governamentais que estão sob sua coordenação, autoridade suficiente para processá-las paralelamente (Rourke 1976; Moe, 1993; Moe and Wilson, 1994; Lupia, 2001).

Esquematizando essas informações a partir do quadro geral do ciclo de políticas públicas, tem-se um primeiro nível de análise, entendido como resultado da delegação de Lula a partir do Gabinete de Crise, e que culminou com a assinatura do Memorando de Entendimento, por Temporão, no qual podem ser percebidas três etapas. A primeira constitui-se na identificação do problema; a segunda diz respeito à busca de alternativas capazes de contorná-lo; e a terceira a resposta encontrada para tal, fases que podem ser representado da seguinte forma:

Figura 11. Processo para o estabelecimento do Memorando de Entendimento para o Fortalecimento do Sistema e dos Serviços Públicos de Saúde e de Vigilância Epidemiológica no Haiti entre Brasil e Haiti

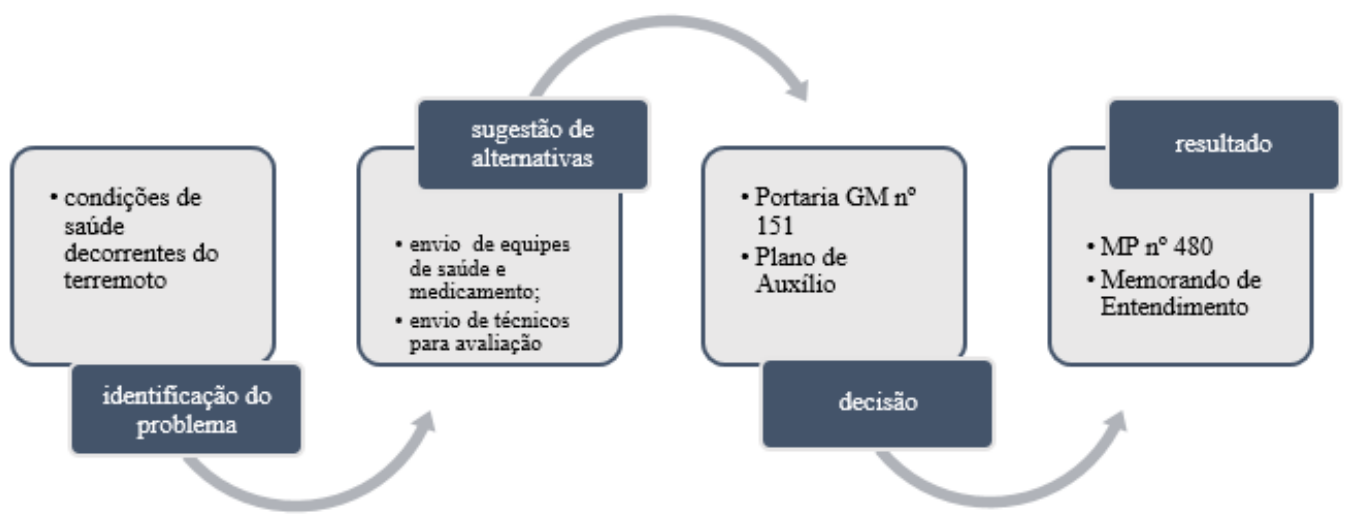

Fonte: elaborado pela autora.

Conforme tem sido afirmado, estas etapas correspondem a uma fase anterior à formulação do projeto em si, e dizem respeito mais especificamente ao processo de tomada de 
decisão, ocorrido a partir da discussão intra-executivo, que se deu entre o presidente Lula e o ministro Temporão, aqui observados no âmbito do Gabinete de Gerenciamento de Crise para o Haiti. Deste modo, atribuindo as devidas competências a cada um dos atores envolvidos nas fases, tem-se a seguinte representação gráfica:

Figura 12. Processo para o estabelecimento do projeto BRA/10/005 entre Brasil e Haiti a partir do reconhecimento da presença dos atores em cada etapa

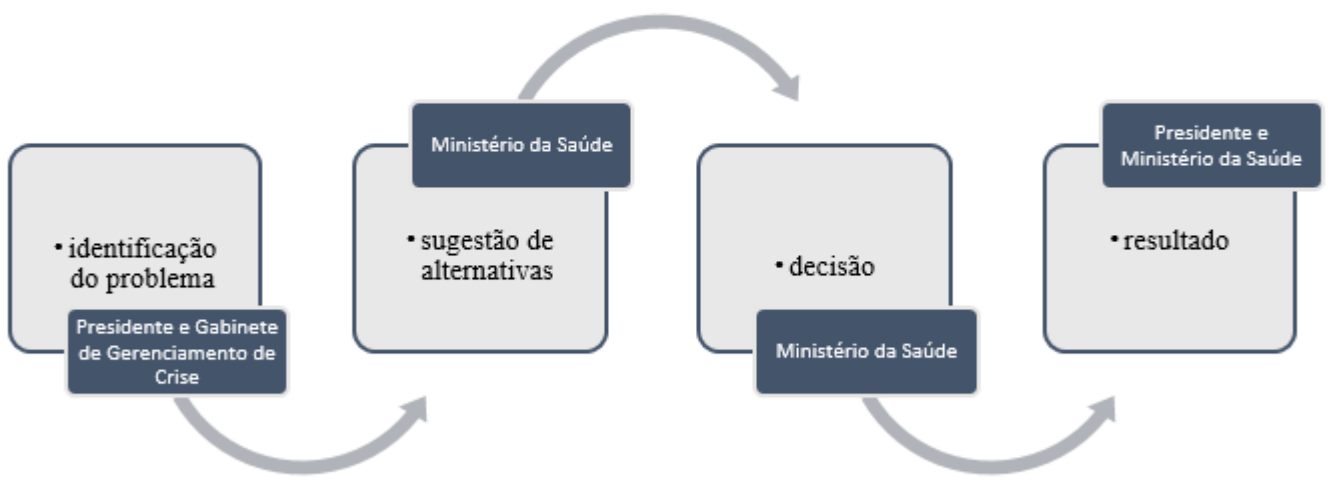

Fonte: elaborado pela autora.

O que a figura acima demonstra, é que em todas as etapas do processo decisório até a assinatura do Memorando de Entendimento, o MS esteve presente em todas as fases, evidenciando o já mencionado processo de horizontalização de competências que aponta para o fato de que, com cada vez mais frequência, o presidente delega aos ministérios setoriais capacidade para atuar em política externa, principalmente em um contexto marcado pelo desenvolvimento e ampliação da cooperação brasileira no âmbito Sul-Sul. A questão que se levanta a partir desta colocação é como o MS, internamente, formulou e implementou esta política.

\subsection{As Competências das Secretarias e Órgãos do MS no âmbito do Grupo de Trabalho Projeto Haiti}

Silva et al. (2010) destacam o novo arranjo institucional decisório, tanto para formular como executar a PEB, o que, por sua vez, evidencia a sua horizontalização. Ainda segundo as autoras, as fases que compõem o processo pela qual as políticas públicas são implementadas, antes de ser um modelo muito bem definido, apresentam fronteiras muito 
tênues entre uma e outra. Ainda assim, reconhecer os atores responsáveis pela condução de cada etapa torna-se muito útil para saber como de fato ela ocorre.

Como já havia sido observado por Cepik e Sousa (2011), alguns desafios entre as etapas foram percebidas no tocante ao MS, sobretudo em relação à falta de sintonia entre os órgãos envolvidos na política de CT. Quando se analisa as competências das secretarias e demais órgãos no ano de 2010, percebe-se que houve uma preocupação com a maneira como estes se articulam, centralizando as decisões no gabinete do ministro, ao qual pertence à AISA, o que poderia significar um avanço diante do quadro caótico ilustrado pelos autores no ano de 2003. Não obstante, não é difícil encontrar secretarias aptas a formular e implementar políticas de cooperação, o que demonstra como a expertise de cada uma delas atua de maneira decisiva neste processo. Ainda que seja tentador dizer que a autonomia está enraizada nos diferentes níveis hierárquicos do MS no âmbito da política externa, é de extrema importância um emprego analítico menos enfático nesse sentido, pois como se verá na sequência, estes órgãos buscam atuar em conformidade com a agenda macro do MS (anexos 4, 5 e 6).

Essa dificuldade de distinção entre as fases, no caso em particular da CTPD, é ainda maior pelo fato de que ela é gerida a partir de modelos normatizados pela $\mathrm{ABC}$ que devem respeitar as etapas apresentadas no capítulo anterior, a saber: identificação; prospecção; formulação e enquadramento; implementação e monitoramento; avaliação e encerramento $^{62}$. Interessa ao trabalho, particularmente as quatro primeiras fases, pois são aquelas nas quais se pode observar melhor a interação entre os atores do Executivo. Para

\footnotetext{
${ }^{62}$ Ver tabela 6 (capítulo 2). As atribuições de competência reconhecidas no regimento interno do MS apontam que estas secretarias, através de suas unidades, estão aptas a atuar em política externa. Não obstante, tendo em vista que o principal objeto da dissertação é a CTPD, seria importante verificar quais deles lidam diretamente com a temática. Nos quadros apresentados nos Anexos 4, 5 e 6 foram feitos grifos nos termos cooperação ou cooperação técnica, na tentativa de focalizar as unidades que atuam em CT, entretanto, o trabalho mostrou-se ineficaz quando realizada uma análise detida em uma unidade específica, a Coordenação-Geral do Programa Nacional de Imunizações, da SVS, responsável por uma das principais políticas de saúde adotada no Haiti a partir de 2010 mas para a qual não aparece nenhuma competência específica em CTPD. Adotar, pois, este critério para definição de secretarias aptas a tratar da temática, pareceu arbitrário.
} 
fins de análise, as três primeiras foram agrupadas no estágio de formulação e a outra em implementação ${ }^{63}$, resultando na seguinte representação:

Figura 13. Representação gráfica dos grupos das unidades do Ministério da Saúde segundo suas competências em 2010

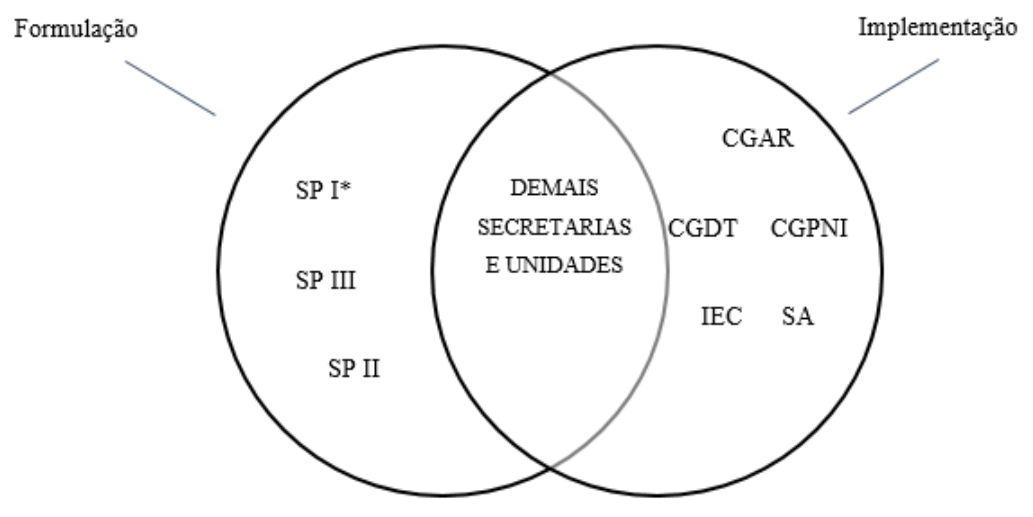

Fonte: Brasil, 2010

*(SP) Serviços de Projeto/ (CGAR) Coordenação-Geral de Assuntos Regulatórios/ (CGDT) Coordenação-Geral de Doenças Transmissiveis/ (CGPNI) Coordenação-Geral do Programa Nacional de Imunizações/ (IEC) Instituto Evandro Chagas/ (SA) Serviço de Administração. (Para ver respectivas secretarias, vide Figura. 7).

Fica demonstrado que existe uma grande dificuldade em isolar cada uma das duas atribuições. Em entrevista com um representante do MS, foi possível verificar que não existe, de forma clara, uma divisão de competências no que diz respeito à política de CTPD, de modo que as informações encontram-se dispersas em cada uma das secretarias, que entendem a AISA como o núcleo concentrador de todas as informações a este respeito. Os resultados da cooperação com o Haiti, por exemplo, somente foram sintetizados e organizados a partir da iniciativa dos próprios técnicos da SecretariaExecutiva inseridos no projeto de cooperação haitiano.

\footnotetext{
${ }^{63} \mathrm{Na}$ ausência de uma descrição explícita de formulação, o critério para que se atribuísse esta função baseou-se nas competências de natureza mais geral como a de "assessoramento", ou "participação" em discussões técnicas no âmbito do MS e/ou organizações internacionais e o "encaminhamento" para as áreas competentes das solicitações de CT. Por outro lado, a implementação foi reconhecida como a fase de consecução destes projetos, descritas no organograma de competências, como promoção, execução, participação, controle, desenvolvimento e gerenciamento. Quando presentes ambas as definições, o órgão foi caracterizado pelas duas fases. As tabelas com todos os órgãos e competências encontram-se nos Anexos 4,5 , e 6 .
} 
Não obstante, o Grupo de Trabalho do Projeto Haiti, instituído pela Portaria GM nº 151, de 15 de janeiro de $2010^{64}$, integrou o Gabinete do Ministro (GM); a Secretaria-Executiva (SE); a Secretaria de Atenção à Saúde (SAS); Secretaria de Ciência, Tecnologia e Insumos Estratégicos (SCTIE); a Secretaria de Vigilância em Saúde (SVS) ${ }^{65}$. Observando as competências de cada uma delas (anexos 4, 5, e 6) bem como de suas unidades que constam na referida portaria, tem-se o seguinte resultado:

\begin{tabular}{|c|c|c|c|c|}
\hline \multicolumn{5}{|c|}{ Tabela 14. Competências das Secretarias e suas Unidades Integrantes do Projeto Haiti de acordo com } \\
Regimento Interno (2010)
\end{tabular}

Fontes: Portaria n ${ }^{\circ} 151$, de 15 de janeiro de 2010 e Ministério da Saúde, 2010b.

O que a tabela demonstra é que, embora o regimento interno não estabelecesse prerrogativas para tratar de assuntos internacionais, os departamentos específicos das secretarias chamadas a somar esforços no pós-terremoto, foram também incorporados ao

\footnotetext{
${ }^{64}$ Este documento sofreu posteriormente duas alterações, sendo uma a Portaria ${ }^{\circ} 1.406$ GM/MS de 15 de junho de 2011 e a outra Portaria nº 1.584 GM/MS de 20 de julho de 2012.

65 Além das secretarias foram chamadas as seguintes entidades: a Fundação Oswaldo Cruz (Fiocruz); a Fundação Nacional de Saúde (Funasa), as quais não serão abordadas pela pesquisa.

${ }^{66}$ A Assessoria de Comunicação Social (ASCOM), não é mencionada no regimento interno do ministério de 2010.
} 
desenvolvimento das ações, muito provavelmente amparados pela elegibilidade de suas secretarias para tal. A tabela seguinte, por sua vez, expõe as funções exercidas por cada um deles no referido projeto.

\begin{tabular}{|c|c|c|}
\hline Secretaria & Unidades & Atividades Realizadas \\
\hline \multirow{2}{*}{$\begin{array}{l}\text { Secretaria de Vigilância em } \\
\text { Saúde (SVS) }\end{array}$} & $\begin{array}{l}\text { Departamento de Vigilância } \\
\text { em Saúde Ambiental e Saúde } \\
\text { do Trabalhador (DVSAST) }\end{array}$ & $\begin{array}{l}\text { Coordenação do GT através de seu Centro de Informações } \\
\text { Estratégicas e Resposta em Vigilância em Saúde (Cievs). }\end{array}$ \\
\hline & $\begin{array}{l}\text { Departamento de Vigilância } \\
\text { Epidemiológica (DEVEP) }\end{array}$ & Fornecimento de 100.000 doses de vacinas contra a Hepatite B. \\
\hline $\begin{array}{l}\text { Secretaria de Atenção à } \\
\text { Saúde (SAS) }\end{array}$ & $\begin{array}{l}\text { Departamento de Atenção } \\
\text { Especializada (DAE) }\end{array}$ & $\begin{array}{l}\text { (1) realização de consultorias a partir do Termo de Cooperação } \\
\mathrm{n}^{\circ} 43 \text { (TC43) firmado com a OPAS para o Desenvolvimento e } \\
\text { Organização de Sistemas e Serviços de Saúde, no Projeto } \\
\text { Instituto Haiti - Brasil de Reabilitação de Pessoas com } \\
\text { Deficiência., do qual resultaram quatro produtos: i) proposta do } \\
\text { planejamento físico de uma Unidade Mista de Saúde, relativa } \\
\text { às atividades a serem desenvolvidas pela unidade; ii) proposta } \\
\text { de programação arquitetônica da Unidade, no que se refere à } \\
\text { definição das áreas do espaço físico; iii) documento técnico } \\
\text { contendo proposta de planejamento físico de uma Unidade de } \\
\text { Reabilitação relativa às atividades a serem desenvolvidas pela } \\
\text { unidade e iv) documento técnico contendo propostas da } \\
\text { programação arquitetônica desta Unidade. (3) a SAS possui } \\
\text { iinda em sua composição a Coordenação-Geral de Sangue e } \\
\text { Hemoderivados para a qual consta a responsabilidade por } \\
\text { traçar um plano de contingência de ajuda ao Haiti a partir de } \\
\text { seu grupo técnico de Captação de Doadores. }\end{array}$ \\
\hline $\begin{array}{l}\text { Secretaria de Ciência, } \\
\text { Tecnologia e Insumos } \\
\text { Estratégicos (SCTIE) }\end{array}$ & $\begin{array}{l}\text { Departamento de Assistência } \\
\text { Farmacêutica e } \\
\text { Insumos Estratégicos (DAF) }\end{array}$ & $\begin{array}{l}\text { (1) Envio de quatro toneladas de medicamentos para apoiar o } \\
\text { combate à epidemia de cólera. (2) integrou a equipe de uma } \\
\text { missão do MS que visitou o Programa de Medicamentos } \\
\text { Essenciais da Organização Pan-Americana da Saúde } \\
\text { (PROMESS) no Haiti. Na ocasião, a delegação brasileira } \\
\text { apresentou os aspectos mais gerais da Política de Medicamentos } \\
\text { do Brasil a fim de auxiliar nas discussões sobre o acesso a } \\
\text { medicamentos e insumos estratégicos essenciais nas Unidades } \\
\text { de Atenção à Saúde. }\end{array}$ \\
\hline \multirow[b]{2}{*}{ Gabinete do Ministro (GM) } & $\begin{array}{l}\text { Assessoria de Comunicação } \\
\text { Social (ASCOM) }\end{array}$ & $\begin{array}{l}\text { Não foi encontrado nenhum registro de atividades específicas } \\
\text { com o Haiti; além disso, no regimento de } 2010 \text {, suas atribuições } \\
\text { não são demonstradas. Pode-se aventar, entretanto, que por } \\
\text { tratar-se de uma Assessoria de Comunicação, coube a ela a a } \\
\text { função de publicizar as iniciativas de cooperação estabelecidas } \\
\text { pelo MS. Ainda assim, optou-se por não dotá-la de ações, das } \\
\text { quais não se tem registros oficiais. }\end{array}$ \\
\hline & $\begin{array}{l}\text { Assessoria de Assuntos } \\
\text { Internacionais de Saúde } \\
\text { (AISA) }\end{array}$ & $\begin{array}{l}\text { Coordenação das diferentes áreas temáticas do MS a partir das } \\
\text { demandas oriundas do governo haitiano. Em entrevista } \\
\text { realizada com a Secretaria-Executiva, foi levantando que todas } \\
\text { as decisões que se relacionam com a cooperação haitiana, são } \\
\text { resultantes de discussões ocorridas no interior do próprio GM, } \\
\text { com a presença, entre outros, do Ministro, de representante da } \\
\text { AISA para o Haiti e do MRE, que uma vez definidas são } \\
\text { repassadas às respectivas áreas técnicas no Ministério, com } \\
\text { interesses nas questões. }\end{array}$ \\
\hline Secretaria Executiva (SE) & $\begin{array}{l}\text { Departamento de Logística } \\
\text { (DLOG) }\end{array}$ & $\begin{array}{l}\text { Em articulação com o DAF, ele responsabilizou-se } \\
\text { imediatamente pela logística dos medicamentos e insumos } \\
\text { estratégicos com a montagem e posterior envio de kits de } \\
\text { calamidade para o Haiti. }\end{array}$ \\
\hline
\end{tabular}

Fontes: Ministério da Saúde, 2010a; 2011a; 2011b; 2012; 2014. 
Complementando as competências da SE expressas na tabela, é importante dizer que no momento da elaboração deste trabalho, a unidade responsável pela gestão do Projeto Haiti era o Departamento de Economia da Saúde, Investimentos e Desenvolvimento $(\mathrm{DESID})^{67}$, com o qual foi realizada a entrevista. Ele responsabilizou-se por prestar apoio técnico para a compatibilização dos projetos executivos e no desenvolvimento de protocolos de recebimento dos equipamentos médico-hospitalares e materiais permanentes adquiridos pelo PNUD (geradores de energia, envio de equipamentos de informação e comunicação, três caminhões da Rede de Frio, fornecimento do gás propano). Além disso, realizou viagens técnicas para supervisionar e acompanhar as atividades ali realizadas pelas demais unidades técnicas do MS, como a construção dos hospitais, centros de reabilitação e laboratório; e a capacitação de profissionais para atuar nos serviços de saúde e prevenção de doenças (relatório de atividades).

A partir dessas informações, é possível determinar que, embora o Gabinete do Ministro e a Secretaria-Executiva, tenham se responsabilizado pela coordenação e acompanhamento do Projeto Haiti, cada secretaria a partir de suas unidades correspondentes participaram de ambas as etapas, fornecendo subsídios técnicos oriundos de suas expertises para a formatação final do PRODOC - BRA/10/005, vinculado ao Memorando de Entendimento. Porém, é salutar que embora possuam atribuições para implementar política externa, os dois primeiros possuem um espaço em separado das demais Secretarias. Isso justifica-se pela própria natureza destes dois órgãos, com funções muito específicas de coordenação e assessoramento do Ministério.

A questão que se levanta em torno das outras secretarias, entretanto, é que as políticas que definiram o escopo do projeto, foram não apenas implementadas, mas também formuladas pelas equipes técnicas que as integram, evidentemente não com irrestrita discricionariedade, uma vez terem sido pautadas nas referidas reuniões mencionadas pelo representante da SE (ver 15) que, em última instância, identificaram os problemas de saúde no Haiti e os informaram internamente.

\footnotetext{
${ }^{67}$ Todo o material fornecido pelo MS acerca da CTPD com o Haiti foi elaborado pelo DESID.
} 
Pode-se dizer que para esse projeto em particular - ainda que seja muito provável a possibilidade de extensão da análise aos demais, guardadas suas devidas particularidades - foram constituídos no interior do ministério dois polos de tomada de decisão, o primeiro em nível político-gerencial, integrando a fase de discussões entre o ministro, a AISA e em alguma medida a SE, orientados, não obstante, pelas deliberações presidenciais e o segundo, por sua vez, em nível político-técnico, entendido como a formulação e implementação de atividades a partir das decisões tomadas no interior do GT do projeto Haiti, do qual participaram as mencionadas secretarias a partir de suas respectivas unidades. A figura seguinte representa esses dados:

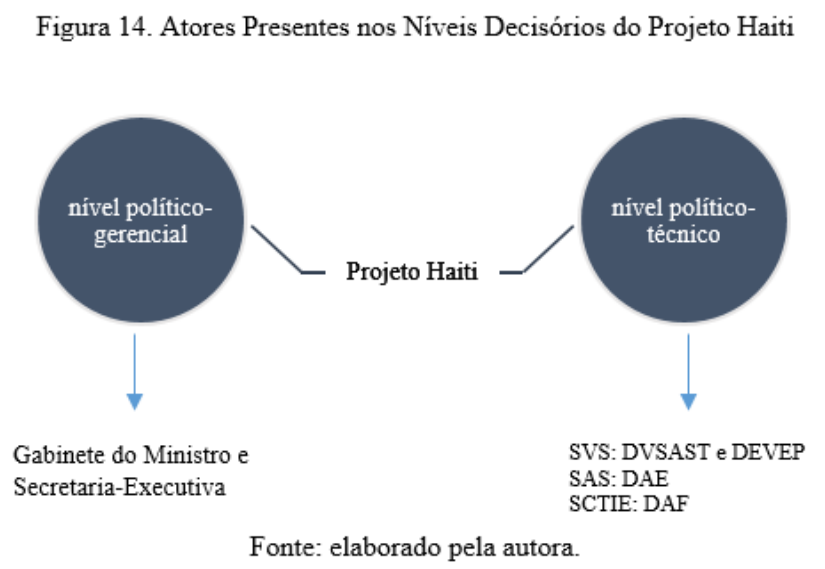

Embora este esquema resuma as competências de cada um dos órgãos, ele apenas é válido quando analisado a partir de uma visão hierárquica mais geral, pois dois fatores causam rupturas nesse fluxo: i) a instituição do Departamento de Vigilância em Saúde Ambiental e Saúde do Trabalhador da SVS enquanto órgão coordenador do GT e ii) o trabalho técnico desempenhado pelo Departamento de Logística (DLOG) da SE.

Evidentemente que o processo de tomada de decisões em qualquer organização, ainda que possa ser amparado por regras legitimadas internamente, não é sempre contínuo e bem delimitado. Entre os estudos que tratam essa questão, conforme pôde ser observado no capítulo 1 , não existe um consenso sobre as etapas e tão pouco uma definição fixa estabelecida para cada uma delas, ao passo que hoje trabalha-se mais sob a perspectiva de um esquema ideal, que propriamente factual. Não obstante, o reconhecimento de um problema, a formulação e a implementação de determinada política, são as fases constantes que em grande medida autorizam a consecução de qualquer decisão. Em termos práticos, isso significa dizer que no momento inicial de composição do Grupo de 
Trabalho, a SE esteve também presente no nível político-técnico e a SVS no políticogerencial, o que corrobora com o argumento de que essas linhas fronteiriças são tênues e discutíveis.

Outrossim, o segundo polo só pode ser entendido como político, para além de sua tecnicidade, quando se entende que os Departamentos e Coordenações-Gerais das Secretarias operam também como decisores e formuladores. Todas as propostas de projetos e, além disso, a própria celebração do Memorando de Entendimento, foram definidas e implementadas a partir das visitas técnicas dos representantes do MS ao Haiti. Este cenário não difere em absoluto daquele no qual estão inseridas as políticas nacionais, em que o processo decisório inclui reiteradas discussões com embasamento técnico de especialistas no assunto.

Figura 15. Fases do Ciclo de Projetos de CTPD

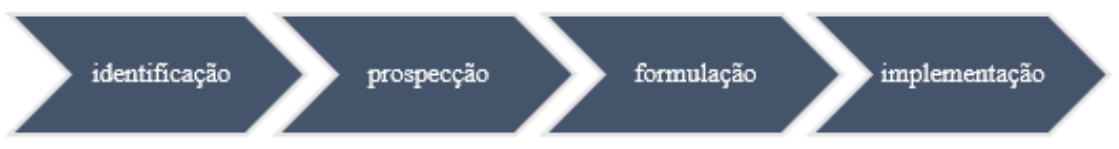

Fonte: $\mathrm{ABC}, 2013$.

Assim, em nível político-técnico, também é estabelecido um fluxo decisório de formulação e implementação. Dois exemplos deste estudo de caso em particular podem ser utilizados para ilustrar esse argumento, sendo o primeiro a SAS. Um dos principais problemas em saúde no Haiti, e que não se iniciou com o terremoto de 2010, era a falta de um programa de atenção básica, uma vez que como dito anteriormente, $80 \%$ da população não tinha acesso ao atendimento médico, recorrendo às práticas locais de cura. No âmbito do Ajuste Complementar para a implementação do projeto Instituto Haiti Brasil de Reabilitação de Pessoas com Deficiência, a Secretaria prestou consultoria em parceria com a OPAS para a construção, equipagem e funcionamento de duas Unidades de Saúde, oferecendo quatro produtos técnicos, que possuíam avaliações e propostas para essa demanda: i) planejamento físico da Unidade Mista de Saúde; ii) atividades a serem desenvolvidas nela; iii) planejamento das atividades a serem desenvolvidas na Unidade de Reabilitação e iv) propostas da programação arquitetônica desta última. A 
implementação dessas inciativas, por sua vez, foram coordenadas e avaliadas pelo DESID, da Secretaria-Executiva.

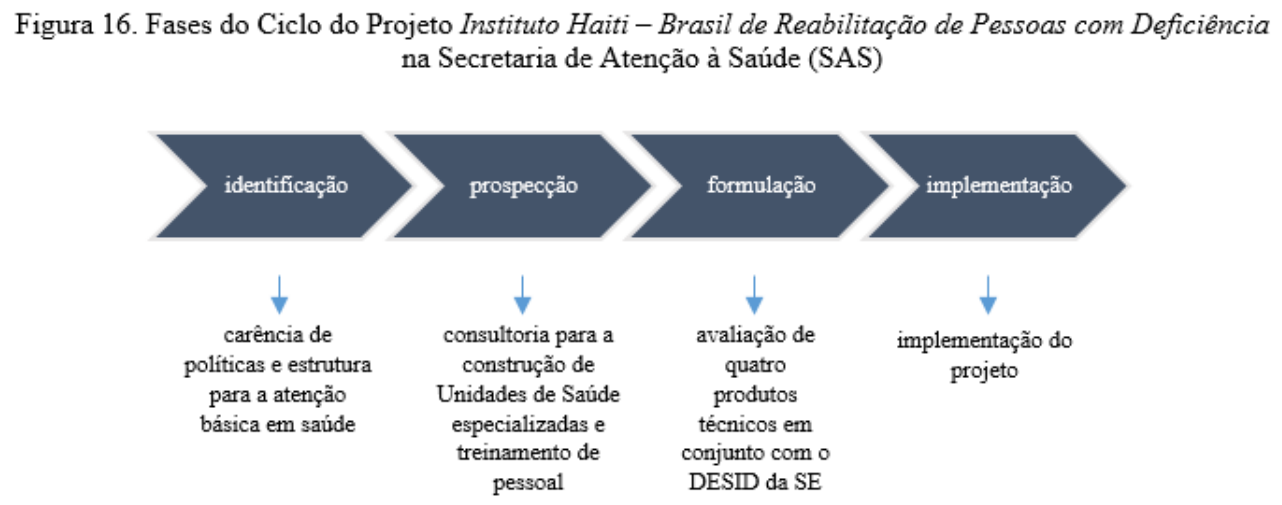

Fontes: ABC, 2013 e Ministério da Saúde, 2011b.

O segundo exemplo é SCTIE, que atuou a partir de seu Departamento de Assistência Farmacêutica e Insumos Estratégicos (DAF), que além da doação de medicamentos, integrou a missão de avaliação do sistema de medicamentos e insumos existente no Haiti por iniciativa da OPAS/OMS, PROMESS. Nas reuniões subsequentes, foi apresentado a Política de Medicamentos do Brasil para discutir o acesso a estes itens pelas Unidades de Atenção à Saúde, que mais tarde proporcionaria a construção, através de orçamento executado pelo PNUD, da Rede de Frio e a doação de três caminhões equipados para realizar o transporte destes medicamentos, que auxiliariam, por seu turno, o grupo de Vigilância Epidemiológica e Imunização, criado pelo Comitê Gestor Tripartite.

Figura 17. Fases do Ciclo do Projeto para a internacionalização de Política de Medicamentos Brasileira pela Secretaria de Ciência, Tecnologia e Insumos Estratégicos (SCTIE)

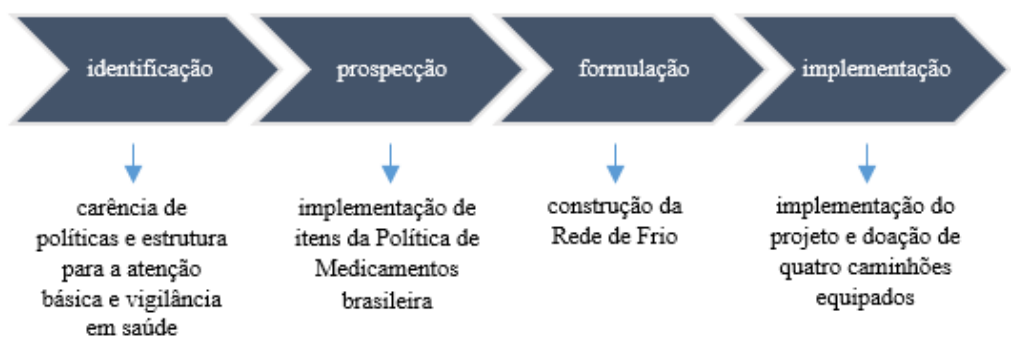

Fontes: ABC, 2013 e Ministério da Saúde, 2011a, 
Pode-se concluir que, embora as atribuições das secretarias estejam muito mais relacionadas ao elemento técnico, a proposta política para o início das discussões sobre determinado problema, cabe exclusivamente a elas que, concentradas no nível-político técnico, oferecem pareceres para a formulação e implementação de política externa no âmbito da CTPD, confirmando a premissa de que cada vez mais deter informação, significa deter também poder político.

\section{Considerações finais}

Na tentativa de verificar o poder discricionário conferido pelo presidente a este ministério, foi possível concluir que o limite concedido à sua inserção internacional, embora tenha permanecido praticamente inalterado no que se refere aos decretos de estrutura regimental, assinados pelo presidente, foi rompido quando se analisa os regimentos internos que definem as competências no interior do ministério, assinados pelo ministro responsável. Isso evidencia que o fato do principal cargo do MS ser ocupado por líderes indicados a partir da barganha política e/ou que compartilhavam os mesmos ideais políticos do presidente Lula, acabou por conformar uma atuação não conflitiva no que diz respeito à imposição de preferências.

Não obstante, os três pontos mais importantes que este estudo de caso possibilita levantar são: i) a participação do presidente Lula se deu no momento relativo à definição da agenda ainda em 2004, sem a qual a CTPD não existiria com a ocorrência do terremoto em 2010, haja visto os laços entre os dois países terem se estabelecido profundamente somente após a MINUSTAH; ii) a política de cooperação técnica só pode ser realizada a partir de ampla delegação de poderes ao ministério (até mesmo para a assinatura de atos internacionais), uma vez que, se não é possível prever de antemão qual a política que pode e deve ser estabelecida com o país com o qual se pretende cooperar, o arranjo institucional apenas pode ser definido posteriormente a estas análises técnicas, que dirão, em última instância, quais secretarias estão aptas a cooperar; e iii) seu desenvolvimento no interior do ministério não obedece a um fluxo de formulação e implementação, rigidamente definido entre os órgãos que o integram. Estas questões, por sua vez, serão desenvolvidas na conclusão final. 


\section{CONCLUSÃO}

Pelo menos nos últimos treze anos, a literatura sobre a Política Externa Brasileira (PEB), vem constantemente apontando para o caráter inovador desta última, vinculada profundamente aos dois mandatos de governo do ex-presidente Luiz Inácio Lula da Silva (2003-2010). Para estes estudiosos, este período correspondeu a significativas alterações na orientação diplomática que até então vinha sendo adotada pelo país, uma vez que a tornou mais comprometida com a agenda política doméstica de Lula, baseada na busca pela supressão de graves problemas sociais.

Atribui-se a este contexto, a ampla aproximação do governo brasileiro com países em desenvolvimento situados politicamente no eixo Sul, a fim de se estabelecer com eles uma extensa rede de cooperação nunca antes observada na história da PEB. No interior desta prática, mais conhecida como Cooperação Sul-Sul (CSS), surgiu a Cooperação Técnica entre Países em Desenvolvimento (CTPD), responsável imediata pela internacionalização das políticas públicas brasileiras.

Importantes estudioso brasileiros atentos ao fenômeno, devotaram seus esforços a fim de compreendê-lo com maior precisão, cabendo destaque os estudos precursores de Maria Regina Soares de Lima, ainda no início dos anos 2000, que buscaram criar o pano de fundo do desenrolar da CSS, em que o Brasil passou a ser reconhecido como um systemaffecting state, participando de foros multilaterais a partir de uma perspectiva de inserção ativa. Tem-se também os trabalhos de Carlos Milani, publicados entre 2013 e 2014, já muito preocupados com a multiplicidade de atores que passaram a participar da agenda de política externa do governo brasileiro, o que levou o autor a pensar esta mudança a partir do conceito de authoritativeness, no qual os órgãos públicos e entidades subnacionais atuariam na CSS a partir da autorização do presidente. Tem-se ainda Letícia Pinheiro, que também vem contribuindo enormemente com essa agenda de pesquisa, culminando particularmente em publicação de 2011, em que ela aborda em um capítulo conjunto com Gregory Beshara, a maneira como o Ministério da Educação (MEC) representa uma nova expressão na arena decisória da PEB, a partir do desenvolvimento de projetos no interior do Mercosul, sinalizando, desta forma, para um maior engajamento dos ministérios em assuntos internacionais e consequentemente para o indubitável fenômeno da horizontalização de competências em política externa. 
Neste ensejo, é sem dúvida muito importante a contribuição de Pimenta de Faria ao debate, a partir de trabalho publicado em 2012, a respeito da importância dos ministérios enquanto atores políticos no contexto da CSS. Ainda que esteja alinhado aos estudos de difusão de políticas públicas, este trabalho também possibilitou a análise da ampliação do escopo da atuação dos ministérios na política externa (Pimenta de Faria, 2012b). Alguns outros trabalhos trataram também a questão do envolvimento dos ministérios brasileiros com a CSS (Albuquerque, 2013; Almeida et al., 2010; Milhorance, 2013), embora o único que tenha conferido destaque ao arranjo institucional privilegiado pela presente dissertação, foi aquele realizado por Cepik e Souza (2011), onde os autores analisam essa questão através do estudo de caso do Ministério da Saúde.

Deste modo, a pesquisa desenvolvida aqui encontra-se em profundo diálogo com estes estudos e busca contribuir com o desenvolvimento de novos procedimentos teóricos e empíricos, a fim de somar esforços na ampliação das agendas de pesquisa da Ciência Política e das Relações Internacionais que tratam da PEB, a partir da análise do processo decisório, como visto, ainda pouco discutido no que diz respeito ao exercício de funções políticas por parte das burocracias ministeriais em política externa.

Com este intuito, parte do trabalho empírico da pesquisa foi inspirado na pesquisa desenvolvida por França e Badin (2010), que analisaram as competências em política externa atribuídas aos ministérios, chegando à conclusão de que a grande maioria deles possuíam, ainda em 2008 , mais de $50 \%$ de suas estruturas comprometidas com questões internacionais. Estudo semelhante, foi realizado por Silva et al., em trabalho publicado pelo Instituto de Pesquisa Econômica Aplicada (IPEA), demonstrando, adicionalmente, que grande parte desta estrutura institucional envolvida com a PEB tem também como prerrogativa legal a sua formulação.

Aferindo as contribuições teóricas, a presente dissertação amplia os estudos sobre a atuação política das burocracias estatais, analisada em contextos domésticos pela Ciência Política. Parte destes trabalhos apoia-se na teoria do principal-agente, que propõe que dada as múltiplas tarefas executadas pelos Estados, grande parte das atividades relativas à formulação e implementação de políticas são delegadas aos quadros burocráticos. A partir disso, buscou-se contribuir com alguns estudos que ressaltam a limitação do processo de delegação, uma vez entenderem que ela só pode ser praticada de modo a 
assegurar os interesses do principal, quando este estabelece mecanismos de controle ex ante. Assim, foi demonstrado, através da relação entre o presidente Lula e o Ministério da Saúde, que a autonomia atribuída ao agente, apenas foi consolidada mediante o reconhecimento adquirido por ele no exercício de suas atividades ao longo de décadas, resultando na confiança expressa do presidente, que, em última instância, foi responsável pela atribuição do seu crescente grau de discricionariedade.

O salto qualitativo, entretanto, diz respeito à transversalidade empregada entre estes estudos e a política externa, para a qual pouca atenção fora dada até então neste sentido. Uma ponto de encontro para este diálogo foram os trabalhos de Krasner (1972) e Rosati (1981), no campo da Análise de Política Externa (APE), em uma crítica endereçada ao Modelo Burocrático desenvolvido por Allison (1971), segundo a qual, o autor ao propor seu modelo de barganhas e conflitos intra-Executivo, teria diminuído a importância do presidente que, além de ser o responsável último pela escolha de sua equipe de governo, detém os mecanismos de controle supracitados para supervisionar os outputs burocráticos, a fim de garantir o alinhamento entre aquilo que ele determina e o que é entregue.

No plano empírico, por sua vez, o estudo de caso da CTPD empreendida pelo MS no Haiti demonstrou como isso ocorre respondendo às duas hipóteses iniciais do trabalho, quais sejam: i) mudanças institucionais promovem mudanças no rumo das políticas que são adotadas, o que atribui ao presidente papel de grande importância para a definição do agenda-setting, ao mesmo tempo em que, ao delegar poderes, ele assegura-se de seus mecanismos de controle; e ii) dado o caráter técnico da CTPD, ela apenas pode ser empreendida a partir da delegação de amplo poder discricionário aos ministérios.

Em relação à primeira, ficou comprovado, no capítulo 2, mediante o emprego do modelo teórico do Ponctuated Equilibrium (Baumgartner e Jones; 1993), que desde a década de 1970, as alternâncias de poder, quando conjugadas a contextos socioeconômicos específicos - e ainda a elementos ideológicos -, resultaram em maior ou menor atenção presidencial à CTPD, medida através da análise quantitativa das proposições enviadas pelos presidentes à Câmara dos Deputados, entre 1970 e 2010. Não obstante, foi demonstrando que durante os dois mandatos do presidente Lula, o número de proposições 
ascendeu paulatinamente, chegando a 108, quando comparadas aos dois mandatos de FHC que somaram 72.

Ainda em relação à primeira hipótese, os capítulos 2 e 3 demonstraram que o presidente Lula desempenhou um papel de extrema importância para o estabelecimento da agenda de cooperação com o Haiti; atenção esta, por sua vez, verificada a partir do emprego do modelo dos Domínios desenvolvido por Rosati (1981). No capítulo 2, isso foi visto quando se observa a presença ativa do presidente quando da decisão de liderar a MINUSTAH em 2004, que culminou na formulação maciça de projetos de CTPD por parte de diferentes ministérios naquele país. No capítulo 3, por sua vez, verifica-se esse alto grau de atenção, quando da ocasião do terremoto em que o presidente determinou a constituição de uma força-tarefa reunida no Gabinete de Gerenciamento de Crise para intensificar a ajuda brasileira ao Haiti, a partir do qual foi deliberada a necessidade do envio de mensagem urgente ao Congresso, por parte do presidente, solicitando a liberação de R 375 milhões para a realização de ações de reconstrução, além dos US\$ 15 milhões que seriam doados pelo país.

Além disso, quando se observou o processo ocorrido entre a definição da agenda pelo presidente e a convocação de seus ministérios, seja em 2004 ou 2010, foi possível perceber que a delegação em CTPD ocorre com frequência e intensidade tal, como em outras políticas domésticas, uma vez serem os ministérios os detentores da expertise necessária para sua consecução. Não obstante, quando se analisou o processo de nomeação dos ministros, um dos mecanismos de controle ex ante apontado pela literatura, percebeu-se de forma muito clara que, ainda que em um contexto marcado pelo regime presidencialista de coalizão, o ex-presidente Lula buscou garantir que os indicados à chefia da pasta fossem responsivos às suas demandas, ora utilizando-se da centralização de decisões através da Casa Civil ora da politização, uma vez ter cedido o comando do MS ao PMDB, partido forte de sua coalizão, durante praticamente todo o período compreendido entre seus dois mandatos, evidentemente que não sem críticos processo de barganha política entre o presidente e os líderes do partido, em que se buscou equilibrar elementos políticos e técnicos para estas nomeações.

Outro mecanismo de controle ex ante considerado capaz de demonstrar o controle do presidente, foram os decretos presidenciais que autorizam as funções no interior do 
ministério em comparação com os regimentos interno destes. A pesquisa demonstrou que esse controle não é efetivo, dado que em 2010, embora o decreto presidencial previsse que apenas três secretarias - mais o Gabinete do Ministro - poderiam atuar em política externa, todas elas, com exceção da Secretaria Especial de Saúde Indígena (SESAI), realizavam atividades internacionais, de acordo com o previsto no regimento interno do ministério naquele ano. Foram, então, levantadas duas possibilidades, que não obstante são complementares, para este descompasso oriundo da comparação dos documentos. A primeira é a que isso pode expressar o esforço realizado pelo ministério em organizar sua estrutura institucional para garantir a execução dos compromissos assumidos pelo governo brasileiro em relação à agenda de política externa do presidente Lula, dada a grande contingência de áreas envolvidas para a consecução da CTPD. A outra é que este dado pode representar a busca de um aperfeiçoamento do MS a fim de ampliar a sua participação na agenda externa, a partir do uso de seu poder discricionário, dotando suas secretarias de autonomia para lidarem com as questões de sua competência e que são do interesse do ministério.

A segunda hipótese, finalmente, argumenta sobre a necessidade do poder discricionário atribuído aos ministérios, devido à tecnicidade da política de CTPD. Ela foi testada a partir de dois testes empíricos: i) a análise qualitativa dos atos internacionais e documentos de projetos de cooperação, e ii) o emprego analítico de Silva et al. (2010), na tentativa de dimensionar a prerrogativa de cada uma das secretarias do Ministério para tratar das questões internacionais.

Em relação ao primeiro, no capítulo 2 foi demonstrado que a CTPD possui uma base jurídica, que são os atos internacionais - de celebração resguardada ao presidente - e outra política, expressa através dos documentos de projeto - sob responsabilidade dos ministérios. A análise qualitativa dos atos internacionais celebrados com o Haiti levantou dois pontos importantes, sendo o primeiro o fato de que o ex-presidente Lula, com exceção do Comunicado Conjunto, de 18 de agosto de 2004, não assinou nenhum deles, ficando boa parte do encargo desta tarefa ao então ministro das Relações Exteriores, Celso Amorim. Como parênteses aqui cabe ressaltar que este fato demonstra que, embora o Ministério das Relações Exteriores (MRE) tenha, ao longo dos anos, perdido sua capacidade de gerência em políticas específicas, na qual se destaca a CTPD, ele continua a desempenhar importante papel como mediador nas negociações entre os países 
cooperantes e os ministérios, além de atuar como formulador de modelos normativos de ação para a cooperação através da Agência Brasileira de Cooperação (ABC).

O segundo ponto levantado, por sua vez, foi o de que três ministros de Lula à época, Patrus Ananias (Ministério do Desenvolvimento Social e Combate à Fome), Fernando Haddad (Ministério da Educação), e José Gomes Temporão (Ministério da Saúde), assinaram atos internacionais com o governo haitiano, sendo o primeiro responsável pela assinatura de dois Ajustes Complementares, e os outros dois por um Memorando de Entendimento cada um, demonstrando de que forma pode-se verificar na prática o conceito de política burocrática, em que a função do agente rompe o limite da implementação, tornando-os também um ator político.

No que diz respeito ao Memorando celebrado por Temporão em 27 de março de 2010, este foi o documento que possibilitou a ampliação do escopo da participação do MS no Haiti, do qual resultou o Projeto Sul-Sul de Fortalecimento da Autoridade Sanitária do Haiti - PRODOC-BRA/10/2005, assinado em 29 de novembro de 2010 em conjunto com o Programa das Nações Unidas para o Desenvolvimento (PNUD), que não obstante, foi utilizado como a principal fonte de dados para o estudo de caso. O Memorando foi assinado em um contexto muito específico marcado pelo terremoto de 12 de janeiro de 2010, a partir do qual, foi instituído o Gabinete de Crise, integrado também pelo ministro da saúde.

A esse respeito, o capítulo 3 demonstrou que, em momento ainda anterior ao Memorando, todo o processo de discussão e avaliação no interior do Gabinete e que resultou nas deliberações feitas pelo presidente Lula por ocasião da reunião ministerial de 21 de janeiro de 2010, foram gestadas a partir de um Plano de Ação desenvolvido pelo próprio MS, consolidado a partir da viagem de seu representante ao Haiti, o qual tornou-se também responsável pela coordenação do Grupo de Trabalho no interior do MS, instituído pela Portaria GM n ${ }^{\circ}$ 151, de 15 de janeiro de 2010.

Estes acontecimentos comprovam o núcleo principal da terceira hipótese, qual seja, o de que a política de CTPD apenas pode ser realizada a partir de ampla delegação de poderes aos ministérios, que irão, por sua vez, cooptar as suas secretarias que estão aptas a tratar do problema em questão, na busca de soluções para o mesmo. Isso pôde ser observado 
através da formação do referido Grupo de Trabalho no Ministério, do qual fizeram parte: Gabinete do Ministro (GM); a Secretaria-Executiva (SE); a Secretaria de Atenção à Saúde (SAS); Secretaria de Ciência, Tecnologia e Insumos Estratégicos (SCTIE) e a Secretaria de Vigilância em Saúde (SVS). Cada uma delas, a partir de suas respectivas unidades, exercem diferentes atribuiçõess, em um primeiro momento, relacionadas à ajuda emergencial mas, posteriormente, como formuladoras e implementadoras de projetos de cooperação estruturante reunidos sob o PRODOC- BRA/10/2005, que a título de nota, é executado até os dias atuais, sendo periodicamente renovado.

Quando se analisou as competências dessas secretarias envolvidas foi possível perceber que algumas de suas unidades que apareciam inseridas no projeto não possuíam prerrogativas legais para atuar em assuntos internacionais, mas ainda assim, integraram os esforços da cooperação com o Haiti. O mais ilustrativo neste caso foi que a divisão entre as ações de cada uma delas a partir do ciclo de políticas públicas, demonstrou-se tênue e passível de discussão, uma vez que órgãos como a SE, a quem cumpre a função de coordenação no MS, atuou no GT como um ator político-técnico, a partir de seu Departamento de Logística (DLOG), ao passo que o Departamento de Vigilância em Saúde Ambiental e Saúde do Trabalhador da Secretaria de Vigilância em Saúde, aparece como ator situado no nível político-gerencial, já que a referida Portaria o instituiu como coordenador do GT.

Para finalizar este levantamento dos principais achados empíricos, é muito importante frisar que, este arranjo institucional do MS só foi possível devido ao poder discricionário colocado à disposição do ministro Temporão para definir, de acordo com sua reconhecida competência, a melhor maneira de atender à convocação do presidente Lula, o qual, por sua vez, depositou sua inteira confiança na certeza de que as respostas encontradas pelo ministério seriam satisfatórias. Com isso, espera-se que esta pesquisa tenha sido capaz de lançar luz sobre importantes aspectos da política burocrática, fornecendo subsídios teóricos e empíricos para o desenvolvimento de trabalho posteriores sobre o tema a fim de contribuir ainda mais com a ampliação da agenda de pesquisa da PEB. 


\section{REFERÊNCIAS BIBLIOGRÁFICAS}

ALBUQUERQUE, FLR de. Atores e agendas da política externa brasileira para a África e a instrumentalização da cooperação em segurança alimentar (2003-2010). 2013. Dissertação (Mestrado) - Universidade do Estado do Rio de Janeiro. Instituto de Filosofia e Ciências Humanas. Rio de Janeiro.

ALLISON, GT. Essence of decision. Explaining the Cuban Missile Crisis. Boston: Little/Brown, 1971.

ALlisOn, GT; HALPERIN, M. Bureaucratic Politics: A Paradigm and Some Policy Implications. World Politcs, v. 24, p. 40-79, 1972.

ALMEIDA, C; CAMPOS, RP de; BUSS, PM; FERREIRA, JR; FONSECA, LE. A Concepção Brasileira de "Cooperação Sul-Sul Estruturante em Saúde”. R. Eletr. de Com. Inf. Inov. Saúde. Rio de Janeiro, v.4, n.1, p.25-35, mar., 2010. Disponível em: http://www6.ensp.fiocruz.br/radis/sites/default/files/pdf/a-concepcao-brasileira-decooperacao-sul-sul-estruturante-em-saude.pdf (Acesso em 27 de maio de 2016).

ALVES, FAP; PAIVA, CHA; SANTANA, JP de. Cooperação Internacional, Política Externa e Saúde: Contribuição ao Processo de Avaliação do Termo de Cooperação Opas-Brasil no 41 (TC41). Observatório História e Saúde - Rede ObservaRH, 2010.

ANASTASIA, F; MENDONÇA, C; ALMEIRDA, H. Poder Legislativo e Política Externa no Brasil: Jogando com as Regras. Contexto Internacional, v. 34, nº 2, p. $617-$ 657, jul/dez 2012.

BAPTISTA, TWF; REZENDE, M. A ideia de ciclo na análise de políticas públicas. In MATTOS, RA; BAPTISTA, TWF (Org). Caminhos para análise das políticas de saúde, $1^{\mathrm{a}}$ ed. Porto Alegre: Rede UNIDA, p.221-272, 2015.

BATISTA, M. O mistério dos ministérios: a governança da coalizão no presidencialismo brasileiro. 2014. Tese (Doutorado) - Universidade Federal de Pernambuco, Pernambuco, 2014. 
BAUMGARTNER, FR; JONES, BD. Agendas and instability, in American politics. Chicago, University of Chicago Press, 1993. In: CAPELLA, CAN. Perspectivas Teóricas sobre Processo de Formulação de Políticas Públicas. São Paulo: BIB, nº 61, pp. 25-52, 2006.

BAUMGARTNER, FR; JONES, BD; TRUE JL. Punctuated-Equilibrium Theory: Explaining Stability and Change in Public Policymaking. In: SABATIER, PA (ed).Theories of the Policy Process. California: Westview Press, 2007.

BAWN, K. Political Control Versus Expertise: Congressional Choices about Administrative Procedures. American Political Science Review, v. 89, $\mathrm{n}^{\circ}$ 1, p. 62-73, march, 1995. Disponível em: http://www.jstor.org/stable/2083075 (Acesso em 05 de maio de 2016).

BENDOR, J; HAMMOND, TH. Rethinking Allison's Models. The American Political Science Review, v. 86, nº 2, p. 301-322, 1992.

BORGES, A; COÊLHO, DB. O Preenchimento de Cargos da Burocracia Pública Federal no Presidencialismo de Coalizão Brasileiro: Análise Comparada de Dois Ministérios: Ciência e Tecnologia e Integração Nacional. In: LOPEZ, FG (org). Cargos de confiança no presidencialismo de coalizão brasileiro. Brasília : IPEA, 2015. Disponível em: http://www.ipea.gov.br/portal/index.php?option=com content $\& v i e w=a r t i c l e \& i d=26222$ (Acesso em 26 de maio de 2016).

BRESSER-PEREIRA, LC. Burocracia Pública e Classes Dirigentes no Brasil. Ver. Sociol. Política, dossiê "Empresariado, Economia e Política", no 28, p. 9-30, junho, 2007.

BREWER, GA. Bureaucratic Politics. In: RABIN, J; WACHLUS, A. (ed.). Encyclopedia of Public Administration and Public Policy. $2^{\mathrm{a}}$ edicação. Volume 1, 2008.

BRIGAGÃO, C. Panorama da diplomacia brasileira para a paz. In: BRIGAGÃO, C; FERNANDES; F (orgs.). Diplomacia brasileira para a paz. Brasília: FUNAG, p.165$181,2012$.

BURKE, JP. Presidential Power: Theories and Dilemmas. Westview Press, 2016. Disponível em: http://orders.westviewpress.com/book-orderform/?isbn=9780813349671\&title=Presidential\%20Power $($ Acesso em 24 de maio de 2016).

BUSS, PM; FERREIRA, JR. Ensaio Crítico sobre a Cooperação Internacional em Saúde. R. Eletr. de Com. Inf. Inov. Saúde. Rio de Janeiro, v.4, n.1, p.93-105, mar., 2010. Disponível em: http://andromeda.ensp.fiocruz.br/radis/sites/default/files/pdf/ensaiocritico-sobre-a-cooperacao-internacional-em-saude.pdf (Acesso em 27 de maio de 2016). 
CAMPINHO, BB. O Direito ao Desenvolvimento como Afirmação dos Direitos Humanos: Delimitação, Sindicabilidade e Possibilidades Emancipatórias. In: PIOVESAN, F; SOARES, IVP (coords.). Direito ao Desenvolvimento. Coleção Fórum Direitos Humanos, v. 2. Belo Horizonte: Fórum, p. 153-178, 2010.

CAMPOS, CR. Delegação e integração regional: aspectos teóricos do paradigma principal-agente aplicado ao sistema europeu. Contexto Internacional, vol. $31, \mathrm{n}^{\circ} 1$, p. 85 114, 2009.

CAPELla, CAN. Perspectivas Teóricas sobre Processo de Formulação de Políticas Públicas. São Paulo: BIB, nº 61, pp. 25-52, 2006.

CARLSNAES, W. Foreign Policy. In: CARLSNAES, W.; RISSE, T.; SIMMONS, B. B. (Org.). Handbook of International Relations. London: SAGE, 2002.

CARPENTER, DP. The Forging of Bureaucratic Autonomy: Reputations, Networks, and Policy Innovation in Executive Agencies, 1862-1928. New Jersey: Princeton University Press, 2001.

CASON, JW; POWER, T. Presidentialization, Pluralizations, and the Rollback of Itamaraty: Explaining Change in Brazil Foreign Policy Making in the Cardoso-Lula Era. International Political Science Review, vol. 30, nº 2, p. 117-140, 2009.

CAVAlCANTE, F. Revisitando o debate nacional: cinco anos da missão no Haiti. Coimbra: Universidade de Coimbra, 2010.

CEPIK, M. SOUSA. A Política Externa Brasileira e a Cooperação Internacional em Saúde no Começo do Governo Lula. Século XXI, Porto Alegre, v. 1, nº 1, p. 109-134, jan-jul. 2011.

CERVO, AL. Socializando o Desenvolvimento; uma História da Cooperação Técnica Internacional do Brasil. Revista Brasileira de Política Internacional. 37 (1), p. 37-63, 1994. Disponível em: https://www.academia.edu/4778231/Socializando_o_desenvolvimento_uma_historia_da _cooperacao_tecnica_internacional_do_Brasil. Acesso em: 17 de julho de 2014.

D’ARAUJO, MC. A Elite Dirigente do Governo Lula. Rio de Janeiro: FGV, 2009.

DINIZ, S. O Senado Federal e a Deliberação de Atos Internacionais no Presidencialismo Brasileiro. Revista Brasileira de Ciências Sociais, v. 27, no 80, p. 169-258, 2012. EPSTEIN, D; O'HALLORAN, S. Administrative Procedures, Information, and Agency Discretion. American Journal of Political Science, v. 38; n³, p. 697-722, august, 1994. 
Disponível em: http://www.columbia.edu/ so33/PublishedPapers/AJPS94.pdf (Acesso em 25 de maio de 2016).

FEREJOHN J; PASQUINO, P. A Teoria da Escolha Racional na Ciência Política: Conceitos de Racionalidade em Teoria Política. Revista Brasileira de Ciências Sociais, v. 16, no 45, p. 5-24, fev., 2001.

FERNANDES, IFA de. Burocracia e Política: A Construção Institucional da Política Comercial Brasileira Pós-Abertura Econômica. 2010. Dissertação (Mestrado) Universidade de São Paulo. Faculdade de Filosofia, Letras e Ciências Humanas. Departamento de Ciência Política. São Paulo.

. A Construção Institucional da Política Comercial Brasileira: A Câmara de Comércio Exterior (CAMEX) no Governo Cardoso. Revista de Sociologia e Ciência Política, v. 21, no 45, p. 123-148, 2013.

FIGUEIRA, ACR. Processo Decisório em Política Externa no Brasil. 2009. Tese (Doutorado) - Universidade de São Paulo. Faculdade de Filosofia, Letras e Ciências Humanas. Departamento de Ciência Política. São Paulo.

FRANÇA, CL de; SANCHEZ BADIN, MR. A inserção internacional do poder executivo federal brasileiro. Análises e Propostas, Friedrich Ebert no Brasil, nº 40, 2010.

FREEDMAN, L. Logic, Politics and Foreign Policy Processes: A Critique of the Bureaucratic Politics Model. International Affairs (Royal Institute of International Affairs 1944-), v. 52, no 3, p. 434-449, 1976.

FREITAS, GG; DOWBOR, M; AMORIM, RLC; et al. Brasil real: a desigualdade para além dos indicadores. Barbosa, AF (org.). São Paulo: Outras Expressões, 2012.

GOMES, FBC. Produção Legislativa no Brasil: Visão Sistêmica e Estratégica no Presidencialismo de Coalizão. Brasília: Biblioteca Digital da Câmara dos Deputados, 2013. Disponível em http://www2.camara.leg.br/documentos-epesquisa/edicoes/paginas-individuais-dos-livros/producao-legislativa-no-brasil-visaosistemica-e-estrategica-no-presidencialismo-de-coalizacao (Acesso em: 23 de maio de 2016).

GOMES, RMS; OLIVEIRA, VC de. Cooperação Internacional Brasil-Cuba-Haiti: o Papel das Rádios Comunitárias no Fortalecimento da Mobilização Social no âmbito da Saúde Pública no Haiti. Ciência \& Saúde Coletiva, 20(1):199-208, 2015. Disponível em: http://www.scielo.br/pdf/csc/v20n1/pt 1413-8123-csc-20-01-00199.pdf (Acesso em 27de junho de 2016). 
GUIMARÃES, FS. Os burocratas das organizações financeiras internacionais: um estudo comparado entre o Banco Mundial e o FMI. Rio de Janeiro: Editora FGV, 2012.

HAMMOND, TH. Veto Points, Policy Preferences, and Bureaucratic Autonomy in Democratic Systems. In: KRAUSE, GA; MEIER, KJ (ed.). Politcs, Policy, and Organizations: Frontiers in the Scientific Study of Bureaucracy. Michigan: University of Michigan Press, 2003. Disponível em: http://www.untagsmd.ac.id/files/Perpustakaan_Digital_1/BUREAUCRACY\%20Politics,\%20Policy,\%20 and\%20Organizations..\%20Study\%20of\%20Bureaucracy.pdf. Acesso em: 11/08/2015.

HAWKINS, DG; LAKE, DA; NIELSON, DL; TIERNEY, MJ. Delegation under anarchy: states, international organizations, and principal-agent theory. In: HAWKINS, DG; LAKE, DA; NIELSON, DL; TIERNEY, MJ (ed.). Delegation and Agency in International Organizations. United Kingdom: Cambridge University Press, 2006.

HINDMOOR, A. Rational Choice. Palgrave Macmillan, 2006.

HIRST, M. Aspectos conceituais e práticos da atuação do Brasil em Cooperação SulSul: os casos de Haiti, Bolívia e Guiné Bissau. Rio de Janeiro: IPEA, 2012. Disponível em: http://www.ipea.gov.br/portal/images/stories/PDFs/TDs/td_1687.pdf. Acesso em: 21/05/2013.

HIRST, M. Aspectos conceituais e práticos da atuação do Brasil em Cooperação SulSul: os casos de Haiti, Bolívia e Guiné Bissau. Rio de Janeiro: IPEA, 2012. Disponível em: http://www.ipea.gov.br/portal/images/stories/PDFs/TDs/td_1687.pdf. Acesso em: 21/05/2013.

HOLLIS, M.; SMITH, S. Roles and Reasons in Foreign Policy Decision Making. British Journal of Political Science, Vol. 16, No. 3, pp. 269-286, 1986. Disponível em: http://www.jstor.org/stable/193813. Acesso em: 19/02/2015.

HOLSTI, JK. National Role Conceptions in the Study of Foreign Policy. International Studies Quarterly, vol. 14, $\mathrm{n}^{\mathrm{o}}$ 3, p. 233-309, 1970. Disponível em: http://www.jstor.org/stable/3013584 (Acesso em 15 de setembro de 2015).

HOWELL, W; LEWIS, D. Agencies by Presidential Design. The Journal of Politics, v. 64, no 4, 2002.

HUBER, G. The Craft of Bureaucratic Neutrality: Interests and Influence in Governmental Regulation of Occupational Safety. Cambridge: Cambridge University Press, 2007.

HUDSON, V. \& VORE, CS. Foreign Policy Analysis Yesterday, Today, and Tomorrow. Mershon International Studies Review, vol. 39, issue 2, p. 209-238, 1995. 
HUDSON, V. Foreign Policy Analysis: Actor-Specific Theory and the Ground of International Relations. Foreign Policy Analysis, vol.1, issue 1, p. 1-30, 2005.

HUNTINGTON, SP. The common defense: strategical programs in national politics. New York: Columbia University Press, 1961.

IGNÁCIO, M. Entre Presidir e Coordenar: Presidência e Gabinetes Multipartidários no Brasil. Apresentado no $3^{\circ}$ Congresso Latino-Americano de Ciência Política, Campinas, 4 a 6 de setembro de 2006.

International Monetary Fund. World Economic Outlook-Recovery Strengthens, Remains Uneven. Washington, 2014. Disponível em: http://www.imf.org/external/pubs/ft/weo/2014/01/pdf/text.pdf. Acesso em 31 de julho de 2014.

KAARBO, J; LANTIS, JS; BEASLEY, KB. The Analysis of Foreign Policy in Comparative Perspective. In: BEASLEY, KB; KAARBO, J; LANTIS, JS; SNARR, MT (eds). Foreign Policy in Comparative Perspective: Domestic and International Influences on State Behavior. Washington, D.C.: Congressional Quarterly Press, 2001.

KICKBUSCH, I; BERGER, C. Diplomacia da Saúde Global. R. Eletr. de Com. Inf. Inov. Saúde. Rio de Janeiro, v.4, n.1, p.19-24, mar., 2010. Disponível em: http://www.reciis.icict.fiocruz.br/index.php/reciis/article/view/693 (Acesso em: $27 \mathrm{de}$ maio de 2016).

KING, G. The Methodology of Presidential Research. In: Researching the Presidency: Vital Questions, New Approaches. EDWARDS III, GC; KESSEL, JH; ROCKMAN, BA (eds). London: University of Pittsburgh Press, 1993. Disponível em: http://users.polisci.wisc.edu/kmayer/828/Moe\%20Presidents\%20Institutions\%20and\%2 0Theory.pdf (Acesso em 24 de maio de 2016).

KINGDON, J. Juntando as Coisas. In: SARAIVA. E; FERRAREZI, E (orgs). Políticas Públicas-Coletânea v. 1. Brasília: ENAP, p. 225 a 245, 2006.

KRASNER, SD. Are Bureaucracies Important? (Or Allison Wonderland). Foreign Policy, no 7, p. 159-179, 1972.

KRAUSE, GA. Agency Risk Propensities Involving the Demand for Bureaucratic Discretion. In: KRAUSE, GA; MEIER, KJ (ed.). Politcs, Policy, and Organizations: Frontiers in the Scientific Study of Bureaucracy. Michigan: University of Michigan Press, 2003. Disponível em: http://www.untagsmd.ac.id/files/Perpustakaan_Digital_1/BUREAUCRACY\%20Politics,\%20Policy,\%20 and $\% 20$ Organizations..\%20Study\%20of\%20Bureaucracy.pdf. Acesso em: 11/08/2015. 
LAFER, C. Comércio, Desarmamento, Direitos Humanos: reflexões sobre uma experiência diplomática. São Paulo: Paz e Terra, 1999.

LEITE, IC; SUYAMA, B; WAISBICH, LT. Para além do tecnicismo: a cooperação brasileira para o desenvolvimento internacional e caminhos para sua efetividade $e$ democratização. Policy Brief in: Conferência Nacional "2003-2013: Uma Nova Política Externa. São Bernardo do Campo, jul; 2013. Disponível em: http://www.cebrap.org.br/v2/files/upload/biblioteca_virtual/item_796/26_08_13_14Poli cy_Briefing_Para\%20a1\%C3\%A9m\%20do\%20tecnicismo.pdf. Acesso em 19/07/2013.

LEWIS, DE. Revisiting the Administrative Presidency: Policy, Patronage, and Agency Competence. Paper presented at the 2007 annual meeting of the Midwest Political Science Association, Chicago, IL, 2007.

LIMA, MRS de. A política Externa Brasileira e dos Desafios da Cooperação Sul-Sul. Revista Brasileira de Política Internacional, vol. 48, nº1, p. 24-59, 2005.

LIMA, MRS de; SANTOS, F. O Congresso e a Política de Comércio Exterior. Revista Lua Nova, no 52, p. 121-149, 2001.

LIMONGI, F. Presidencialismo, coalizão partidária e processo decisório. Novos Estudos, no 76, p. 17-41, 2006.

LIMONGI, F; FIGUEIREDO, A. Bases Institucionais do Presidencialismo de Coalizão. Lua Nova, no 44, p. 81-215, 1998.

LINDBLOM, CE. The Science of "Muddling Through". Public Administration Review, v. $19, \mathrm{n}^{\mathrm{o}} 2$, p. $79-88,1959$.

LOPES, DB. A política externa brasileira e a "circunstância democrática": do silêncio respeitoso à politização ruidosa. Revista Brasileira de Política Internacional, vol. 54, $\mathrm{n}^{\circ}$ 1, p. 67-86, 2011.

LOPEZ, FG (org). Cargos de confiança no presidencialismo de coalizão brasileiro. Brasília : IPEA, $2015 . \quad$ Disponível em: http://www.ipea.gov.br/portal/index.php?option=com content $\& v i e w=a r t i c l e \& i d=26222$ (Acesso em 26 de maio de 2016).

LOPEZ, FG; BUGARIN, M; BURAGIN, K. Mudanças Político-Partidárias e Rotatividade dos Cargos de Confiança (1999-2013). In: LOPEZ, FG (org). Cargos de confiança no presidencialismo de coalizão brasileiro. Brasília : IPEA, 2015. Disponível em:http://www.ipea.gov.br/portal/index.php?option=com content\&view=article \&id=26 $\underline{222}$ (Acesso em 26 de maio de 2016). 
LOPEZ, FG; PRAÇA, S. Critérios e Lógicas de Nomeação para o Alto Escalão da Burocracia Federal Brasileira. In: LOPEZ, FG (org). Cargos de confiança no presidencialismo de coalizão brasileiro. Brasília : IPEA, 2015. Disponível em: http://www.ipea.gov.br/portal/index.php?option=com_content $\& v i e w=\operatorname{article} \& i d=26222$ (Acesso em 26 de maio de 2016).

LOUREIRO, MR; ABRUCIO, F. Política e Burocracia no Presidencialismo Brasileiro: o Papel do Ministério da Fazenda no Primeiro Governo Fernando Henrique Cardoso. Revista Brasileira de Ciências Sociais, p. 69-89, outubro, 1999.

LUPIA, A. 2001. Delegation of Power: Agency Theory. In: SMELSER, NJ.; BALTES, PB. (eds.). International Encyclopedia of the Social and Behavioral Sciences. Oxford: Elsevier Science Limited, 2001. Disponível em: http://acqnotes.com/Attachments/Delegation\%20of\%20Power\%20Agency\%20Theory.p df (Acesso em 27 de abril de 2015).

MEIER, KJ. Politics and the bureaucracy: policymaking in the fourth branch of government. Duxbury Press, 1979.

MEIER, KJ; KRAUSE, GA. The Scientific Study of Bureaucracy: An Overview. In: KRAUSE, GA; MEIER, KJ (ed.). Politcs, Policy, and Organizations: Frontiers in the Scientific Study of Bureaucracy. Michigan: University of Michigan Press, 2003. Disponível em: http://www.untagsmd.ac.id/files/Perpustakaan Digital 1/BUREAUCRACY\%20Politics, \%20Policy,\%20 and\%20Organizations..\%20Study\%20of\%20Bureaucracy.pdf. Acesso em: 11/08/2015.

MILANI, C. Brazil's South-South Co-operation Strategies: From Foreign Policy to Public Policy. Occasional Paper $n^{\circ} 179$, South Africa Institute of International Affairs, Março de 20014.

MILANI, CRS; LOPES, RN. Cooperação Sul-Sul e Policy Transfer em Saúde Pública: análise das relações entre Brasil e Moçambique entre 2003 e 2012. Carta Internacional, vol. $9, \mathrm{n}^{\circ} 1$, p. $59-78,2014$.

MILHORANCE, C. A política de cooperação do Brasil com a África Subsaariana no setor rural: transferência e inovação na difusão de políticas públicas. Revista Brasileira de Política Internacional, v. 56, nº 2, p. 5-22, 2013.

MILNER, HV. Interests, Institutions and Information: Domestic Politics and International Relations. Princeton: Princeton University Press, 1997.

MISOCZKY, MC; BORDIN, E; BARCELOS, R (org). Fortalecimento da Rede de Serviços de Saúde: um Relato da Cooperação Brasil/Cuba/Haiti. Porto Alegre: 
Pubblicato

Editora,

2015.

Disponível

em:

http://www.lume.ufrgs.br/handle/10183/130357 (Acesso em 22 de maio de 2016).

MOE, TM. Presidents, Instituitions and Theory. In: Researching the Presidency: Vital Questions, New Approaches. EDWARDS III, GC; KESSEL, JH; ROCKMAN, BA (eds). London: University of Pittsburgh Press, 1993. Disponível em: http://users.polisci.wisc.edu/kmayer/828/Moe\%20Presidents\%20Institutions\%20and\%2 OTheory.pdf (Acesso em 24 de maio de 2016).

MOE, TM; WILSON, SA. Presidents and the Politics of Structure. Law and Contemporary Problems, v. 57, $\mathrm{n}^{\mathrm{o}}$ 2, 1994. Disponível em: http://scholarship.law.duke.edu/cgi/viewcontent.cgi?article=4225\&context=lcp $\quad$ (Acesso em 10 de maio de 2016).

NEUSTADT, RE. Alliance Politics. New York: Columbia University Press, 1970.

NISKANEN, W. Bureaucracy and Representative Government. Chicago: AldineAtherton, 1971.

OLIVEIRA, HA de. Política Externa Brasileira. São Paulo: Ed. Saraiva, 2005.

PEREIRA, C; PRAÇA, S; BATISTA, M; LOPEZ, FG. A Nomeação De SecretáriosExecutivos E O Monitoramento Da Coalizão No Presidencialismo Brasileiro. In: LOPEZ, FG (org). Cargos de confiança no presidencialismo de coalizão brasileiro. Brasília : IPEA, $2015 . \quad$ Disponível em: http://www.ipea.gov.br/portal/index.php?option=com content $\& v i e w=a r t i c l e \& i d=26222$ (Acesso em 26 de maio de 2016).

PESSÔA, LR; FERLA, AA; ANDRADE, J; MENEGHEL, S; LINGER, CA; KASTRUP, E. A Educação Permanente e a Cooperação Internacional em Saúde: um Olhar sobre a Experiência de Fortalecimento da Rede Haitiana de Vigilância, Pesquisa e Educação em Saúde, no âmbito do Projeto TRIPARTITE Brasil-Haiti-Cuba. Divulgação em Saúde para Debate, $\mathrm{n}^{\mathrm{o}}$ 49, p. 165-171, out. 2013. Disponível em: http://www.ensp.fiocruz.br/portalensp/informe/site/arquivos/anexos/63802503ec0a8c6a 0118ff263102e43216771f9f.PDF (Acesso em 27 de junho de 2016).

PIMENTA DE FARIA, CA. O Itamaraty e a Política Externa: do insulamento à busca de coordenação dos atores governamentais e de cooperação com os agentes societários. Contexto Internacional, vol. 34, $\mathrm{n}^{\mathrm{o}}$ 1, janeiro/junho, p. 311-355, 2012a.

A difusão de políticas sociais como estratégia de inserção internacional: Brasil e Venezuela comparados. Intersecções, v.14, n² , dezembro, p. 335371, $2012 b$. 
PINHEIRO, L.; BESHARA, G. Política externa e educação: confluências e perspectivas no marco da integração regional. In: PINHEIRO, L.; MILANI, C. (orgs). Política externa brasileira: a política das práticas e as práticas da política. Rio de Janeiro: Editora FGV, 2011.

PIOVESAN, F. Direito ao Desenvolvimento - Desafios contemporâneos. In: PIOVESAN, F; SOARES, IVP (coords.). Direito ao Desenvolvimento. Coleção Fórum Direitos Humanos, v. 2. Belo Horizonte: Fórum, p. 95-116, 2010.

PIRES-ALVEZ, FA; PAIVA, CHA; SANTANA, JP de; MEJÍA, DV. A Cooperação Técnica Opas-Brasil e o Desenvolvimento de Recursos Humanos em Saúde: Trajetórias Históricas e Agendas Contemporâneas. R. Eletr. de Com. Inf. Inov. Saúde. Rio de Janeiro, v.4, n.1, p.68-77, mar., 2010. Disponível em: http://www.reciis.icict.fiocruz.br/index.php/reciis/article/view/700. (Acesso em: $27 \mathrm{de}$ maio de 2016).

PUTNAM, RD. Diplomacy and Domestic Politics: The Logic of Two-Level Games. International Organization, v. 42, nº. 3. p. 427-460, 1988.

REIS, RR. Os direitos humanos e a política internacional. Revista de Sociologia e Política, 27, p. 33-42, nov, 2006.

RISSE-KAPPEN, T. (Org.) Bringing Transnational Relations Back In: Non-State Actors, Domestic Structures and International Institutions. New York: Cambridge University Press, 1995.

RISSE-KAPPEN, T. Public Opinion, Domestic Structure, and Foreign Policy in Liberal Democracies. World Politics, vol. 43, $\mathrm{n}^{\circ}$ 4, p. 479-512, 1991. Disponível em: http://www.jstor.org/stable/2010534 (Acesso em 15 de setembro de 2015).

ROBINSON, SE. Ponctuated Equilibrium. In BERMAN EM (ed). Encycolpedia of Public Administrations and Public Policy, Second Edition. CRC Press, 2007.

RODRIGUES, GMA. A política externa brasileira e a prevenção de conflitos internacionais. In: BRIGAGÃO, C; FERNANDES, F (orgs.). Diplomacia brasileira para a paz. Brasília: FUNAG, p.183-213, 2012.

ROSATI, J. Developing a Systematic Decision-Making Framework: Bureaucratic Politics in Perspective. World Politics, v. 33, n 2, p. 234-252, 1981.

ROURKE, FE. Bureaucracy, Politics and Public Policy. Toronto: Little, Brown \& Company Limited, 1976. 
SANCHEZ, MR; SILVA, ECG da; CARDOSO, EL; SPÉCIE, P. Política Externa como Política Pública: Uma Análise pela Regulamentação Constitucional Brasileira (19671988). Rev. Sociol. Polit., no 27, p. 125-143, nov. 2006.

SANTANA, JP de. Um Olhar sobre a Cooperação Sul-Sul em Saúde. Ciência \& Saúde Coletiva, 16(6), p. 2993-3002, 2011. Disponível em: http://www.scielo.br/pdf/csc/v16n6/37.pdf (Acesso em: 27 de maio de 2016).

SARAIVA, MG. As estratégias de cooperação Sul-Sul nos marcos da política externa brasileira de 1993 a 2007. Revista Brasileira de Política Internacional, v. 50, nº 2, p. 4259, 2007.

SELZNICK, P. TVA and the grass roots. A study in the sociology of formal organizations. California: University of California Press, 1949.

SHAPIRO, RY; MCCANN, SJH. The Rational Public: Fifty Years of Trends in American Policy Preferences by Benjamin I. International Society of Political Psychology, vol. 15, $\mathrm{n}^{\circ}$ 3, p. 589-593, 1994. Disponível em: http://www.jstor.org/stable/3791577 (Acesso em 15 de setembro de 2015).

SILVA, ECG da; SPÉCIE, P; VITALE, D. Atual Arranjo Institucional da Política Externa Brasileira. Brasília: IPEA, 2010. Disponível em: http://www.ipea.gov.br/portal/index.php?option=com content\&view=article\&id=5046. (Acesso em 18 de fevereiro de 2016).

SIMON, H. A racionalidade do processo decisório em empresas. Rio de Janeiro: Multipl. v. 1, n. 1, 1980.

SIQUEIRA, CD. Burocracia Pública e a Tomada de Decisão em Política Externa. Meridiano 47, v. 12, n 128, p. 10-17, nov-dez, 2011.

SOUZA, Celina. Condições institucionais de cooperação na região metropolitana de Salvador. In: CARVALHO, I. M. M.; PEREIRA, G. C. (Org.). Como anda Salvador e sua região metropolitana. Salvador: Edufba. p. 171-185, 2006a.

SOUZA, C. Políticas Públicas: Uma Revisão da Literatura. Sociologias, Porto Alegre, ano $8, n^{\circ} 16$, p. 20-45, jul/dez 2006b.

VAlleR FILHO, W. O Brasil e a Crise Haitiana: A cooperação Técnica como Instrumento de Solidariedade e de Ação Diplomática. Brasília: FUNAG, 2007.

VIEIRA, MM. Controle Político da Burocracia no Presidencialismo de Coalizão. 2013. Tese (Doutorado) - Universidade do Estado do Rio de Janeiro. Centro de Ciências Sociais. Instituto de Estudos Sociais e Políticos, Rio de Janeiro, 2013. 
VILLARINHO, MV; PADILHA, MI; BERARDINELLI, LMM; BORENSTEIN, MS; MEIRELlES, BHS; ANDRADE, SR de. Políticas Públicas de Saúde face à Epidemia da AIDS e a Assistência às Pessoas com a Doença. Rev Bras Enferm,; 66(2): 271-7, marabr 2013.

VIZENTINI, PF. Relações Internacionais do Brasil: de Vargas a Lula. São Paulo: Editora Fundação Perseu Abramo, 2012.

WATERMAN, RW; MEIER, KJ. Principal-Agent Models: An Expansion? Journal of Public Administration and Theory, J-Part 8: 2, p. 173-202, 1998.

WEBER, M. Os fundamentos da organização burocrática: uma construção do tipo ideal. In: CAMPOS, E (org.). Sociologia da Burocracia. Rio de Janeiro: Zahar Editora, 1966.

WEINGAST, BR. The congressional bureaucratic system: a principal-agent perspective (with some applications to the SEC). Public Choice. Col. 44, 1984.

\section{Relatórios}

AGÊNCIA BRASILEIRA DE COOPERAÇÃO. Manual de Gestão da Cooperação Técnica Sul-Sul. Brasília: 2013. Disponível em: http://www.abc.gov.br/Content/ABC/docs/Manual SulSul Final-

Diagramado Corrigido 23-04-2014.pdf (Acesso em 23 de julho de 2014).

AGÊNCIA BRASILEIRA DE COOPERAÇÃO; INSTITUTO BRASILEIRO DE PESQUISA ECONÔMICA APLICADA (IPEA). Cooperação Brasileira para o Desenvolvimento Internacional: 2005-2009. Brasília, IPEA: 2010.

AGÊNCIA BRASILEIRA DE COOPERAÇÃO; INSTITUTO BRASILEIRO DE PESQUISA ECONÔMICA APLICADA (IPEA). Cooperação Brasileira para o Desenvolvimento Internacional: 2005-2009. Brasília, IPEA: 2010.

BRASIL. Objetivos do Milênio: Relatório Nacional de Acompanhamento. Ipea: Brasília, $2014 . \quad$ Disponível em: http://www.ipea.gov.br/portal/images/stories/PDFs/140523 relatorioodm.pdf (Acesso em 01 de junho de 2016).

MINISTÉRIO DA SAÚDE. Assessoria de Assuntos Internacionais de Saúde: Relatório de Gestão 2009. Brasília, 2010a. Disponível em: http://bvsms.saude.gov.br/bvs/publicacoes/relatorio gestao 2009 assessoria assuntos.p df (Acesso em 30 de maio de 2016). 
MINISTÉRIO DA SAÚDE. Assessoria de Assuntos Internacionais de Saúde: Relatório de Gestão 2010. Brasília, 2011.

MINISTÉRIO DA SAÚDE. Cooperação em Saúde no Haiti: Quatro Anos de Construção. Brasília, 2014.

MINISTÉRIO DA SAÚDE. Coordenação-Geral de Sangue e Hemoderivados: Relatório de Gestão 2010. Brasília, 2011. Disponível em: http://bvsms.saude.gov.br/bvs/publicacoes/relatorio_gestao_2010_sangue_hemoderivad os.pdf (Acesso em 27 de junho de 2016).

MINISTÉRIO DA SAÚDE. Departamento de Economia da Saúde, Investimentos e Desenvolvimento: Relatório de Gestão 2013. Brasília, 2014. Disponível em: http://u.saude.gov.br/images/pdf/2014/agosto/15/Relat--rio-de-Gest--o-DESID-2013.pdf (Acesso em 22 de maio de 2016).

MINISTÉRIO DA SAÚDE. Programa Naciona de Imunizações - 30 anos. Brasília: 2003.

MINISTÉRIO DA SAÚDE. Regimentos Internos e Organogramas Básicos do Ministério da Saúde. $\quad$ Brasília, 2005. Disponível em http://bvsms.saude.gov.br/bvs/publicacoes/regimentos internos organogramas minister io saude.pdf (Acesso em 05 de janeiro de 2016).

MINISTÉRIO DA SAÚDE. Secretaria de Atenção à Saúde: Relatório de Gestão 2010. Brasília, 2011. Disponível em: http://u.saude.gov.br/images/pdf/2014/abril/01/relatoriode-gestao-sas-2010.pdf (Acesso em 22 de maio de 2016).

MINISTÉRIO DA SAÚDE. Secretaria de Atenção à Saúde: Relatório de Gestão 2011. Brasília, 2012. Disponível em: http://u.saude.gov.br/images/pdf/2014/abril/01/relatoriode-gestao-sas-2011.pdf (Acesso em 22 de maio de 2016).

MINISTÉRIO DAS RELAÇÕES EXTERIORES. Atos Internacionais: Prática Diplomática Brasileira - Manual de Procedimentos. Brasília: 2008. Disponível em: http://dai-mre.serpro.gov.br/clientes/dai/dai/manual-de-procedimentos/manual-deprocedimentos-pratica-diplomatica (Acesso em 15 de junho de 2014).

MINISTÉRIO DAS RELAÇÕES EXTERIORES; AGÊNCIA BRASILEIRA DE COOPERAÇÃO. Brasil - Haiti: Programa de cooperação Sul-Sul. Brasília, s/d. 84 p.

MINISTÉRIO DO PLANEJAMENTO. Balanço de Governo: 2003 a 2010. Brasília, 2010 .

Disponível

em:

https://i3gov.planejamento.gov.br/balanco/4\%20.../Balanco\%20Completo\%20MRE.doc (Acesso em 04 de maio de 2016). 
MINSTÉRIO DA SAÚDE. Regimentos Internos e Organogramas Básicos do Ministério da Saúde. Brasília, 2010b. Disponível em: http://bvsms.saude.gov.br/bvs/publicacoes/regimentos_internos_organogramas_basicos ms.pdf (Acesso 05 de janeiro de 2016).

ORGANIZAÇÃO DAS NAÇÕES UNIDAS. The Millennium Development Goals Report: 2015. Nova York, 2015. Disponível em: http://www.un.org/millenniumgoals/2015_MDG_Report/pdf/MDG\%202015\%20rev\%2 0(July\%201).pdf (Acesso em 01 de junho de 2016).

ORGANIZAÇÃO MUNDIAL DA SAÚDE. Health in the Americas, v. 2. Washington, D.C., $2007 . \quad$ Disponível em: http://www2.paho.org/saludenlasamericas/dmdocuments/health-americas-2007-vol2.pdf (Acesso em 27 de junho de 2016).

\section{Documentos}

CASTRO, JAA (1963). Discurso dos Três D's. 18 a Assembleia Geral das Nações Unidas em 19 de setembro. Disponível em: http://diplomaciapublica.itamaraty.gov.br/onu/41-odiscurso-dos-tres-ds. Acesso em 19 de julho de 2014.

Joint Declaration of the seventy-seven developing countries made at the conclusion of the Unitade Nations Conference on Trade and Development. Geneva, 15 June 1964. Disponível em: http://www.g77.org/doc/Joint\%20Declaration.html. Acesso em: 19 de julho de 2014. 


\section{ANEXO 1}

\begin{tabular}{|c|c|c|c|c|}
\hline $\begin{array}{l}\text { Natureza do ato } \\
\text { internacional }\end{array}$ & Projeto & Data & $\begin{array}{c}\text { Autoridade } \\
\text { Brasileira }\end{array}$ & Função \\
\hline Acordo Básico* & - & $15 / 10 / 1982$ & $\begin{array}{l}\text { Ramiro } \\
\text { Saraiva } \\
\text { Guerreiro } \\
\end{array}$ & $\begin{array}{l}\text { Ministro das } \\
\text { Relações } \\
\text { Exteriores }\end{array}$ \\
\hline Ajuste Complementar & $\begin{array}{l}\text { Transferência de Tecnologias em Sistema } \\
\text { de Produção e Processamento de Caju }\end{array}$ & $20 / 12 / 2004$ & $\begin{array}{l}\text { Celso } \\
\text { Amorim }\end{array}$ & $\begin{array}{l}\text { Ministro das } \\
\text { Relações } \\
\text { Exteriores }\end{array}$ \\
\hline Ajuste Complementar & Desenvolvimento da Cultura da Mandioca & $20 / 12 / 2004$ & $\begin{array}{l}\text { Celso } \\
\text { Amorim }\end{array}$ & $\begin{array}{l}\text { Ministro das } \\
\text { Relações } \\
\text { Exteriores }\end{array}$ \\
\hline $\begin{array}{l}\text { Memorando de } \\
\text { Entendimento }\end{array}$ & $\begin{array}{c}\text { Memorando de entendimento entre o } \\
\text { Governo do Brasil e a Organização das } \\
\text { Nações Unidas para a Agricultura e a } \\
\text { Alimentação (FAO) }\end{array}$ & $17 / 10 / 2005$ & $\begin{array}{c}\text { Fernando } \\
\text { Haddad }\end{array}$ & $\begin{array}{l}\text { Ministro da } \\
\text { Educação }\end{array}$ \\
\hline Ajuste Complementar & $\begin{array}{l}\text { Aprimoramento do Programa Haitiano de } \\
\text { Imunizações }\end{array}$ & $23 / 05 / 2006$ & $\begin{array}{l}\text { Celso } \\
\text { Amorim }\end{array}$ & $\begin{array}{l}\text { Ministro das } \\
\text { Relações } \\
\text { Exteriores }\end{array}$ \\
\hline Ajuste Complementar & $\begin{array}{l}\text { Aprimoramento do Programa Haitiano de } \\
\text { Imunizações }\end{array}$ & $23 / 05 / 2006$ & $\begin{array}{l}\text { Celso } \\
\text { Amorim }\end{array}$ & $\begin{array}{l}\text { Ministro das } \\
\text { Relações } \\
\text { Exteriores }\end{array}$ \\
\hline Ajuste Complementar & Inserção Social pela Prática Esportiva & $23 / 05 / 2006$ & $\begin{array}{l}\text { Celso } \\
\text { Amorim }\end{array}$ & $\begin{array}{l}\text { Ministro das } \\
\text { Relações } \\
\text { Exteriores }\end{array}$ \\
\hline $\begin{array}{l}\text { Memorando de } \\
\text { Entendimento }\end{array}$ & $\begin{array}{l}\text { Memorando de Entendimento entre o } \\
\text { Governo da República Federativa do } \\
\text { Brasil e o Governo da República } \\
\text { Argentina para o Desenvolvimento de } \\
\text { Ações Conjuntas de Cooperação Técnica } \\
\text { em prol do Haiti }\end{array}$ & $23 / 05 / 2006$ & $\begin{array}{l}\text { Celso } \\
\text { Amorim }\end{array}$ & $\begin{array}{l}\text { Ministro das } \\
\text { Relações } \\
\text { Exteriores }\end{array}$ \\
\hline $\begin{array}{l}\text { Memorando de } \\
\text { Entendimento }\end{array}$ & $\begin{array}{l}\text { Memorando de Entendimento entre a } \\
\text { República Federativa do Brasil e o Banco } \\
\text { Internacional para a Reconstrução e o } \\
\text { Desenvolvimento para Implementação da } \\
\text { Fase II do Programa Nacional de Merenda } \\
\text { Escolar no Haiti }\end{array}$ & $23 / 05 / 2006$ & $\begin{array}{l}\text { Celso } \\
\text { Amorim }\end{array}$ & $\begin{array}{l}\text { Ministro das } \\
\text { Relações } \\
\text { Exteriores }\end{array}$ \\
\hline Ajuste Complementar & $\begin{array}{c}\text { Construção de Cisternas Familiares e } \\
\text { Validação Social de Cultivares de } \\
\text { Hortaliças }\end{array}$ & $30 / 11 / 2006$ & $\begin{array}{l}\text { Ruy Nunes } \\
\text { Pinto } \\
\text { Nogueira }\end{array}$ & $\begin{array}{l}\text { Subsecretário- } \\
\text { Geral de } \\
\text { Cooperação e } \\
\text { Comunidades } \\
\text { Brasileiras no } \\
\text { Exterior } \\
\end{array}$ \\
\hline Ajuste Complementar & $\begin{array}{l}\text { Manejo e Reconstituição da Cobertura } \\
\text { Vegetal da Bacia do Mapou }\end{array}$ & $30 / 11 / 2006$ & $\begin{array}{l}\text { Ruy Nunes } \\
\text { Pinto } \\
\text { Nogueira }\end{array}$ & $\begin{array}{l}\text { Subsecretário- } \\
\text { Geral de } \\
\text { Cooperação e } \\
\text { Comunidades } \\
\text { Brasileiras no } \\
\text { Exterior } \\
\end{array}$ \\
\hline Ajuste Complementar & $\begin{array}{c}\text { Construção de Cisternas Familiares e } \\
\text { Validação Social de Cultivares de } \\
\text { Hortaliças }\end{array}$ & $30 / 11 / 2006$ & $\begin{array}{l}\text { Ruy Nunes } \\
\text { Pinto } \\
\text { Nogueira }\end{array}$ & $\begin{array}{l}\text { Subsecretário- } \\
\text { Geral de } \\
\text { Cooperação e } \\
\text { Comunidades } \\
\text { Brasileiras no } \\
\text { Exterior } \\
\end{array}$ \\
\hline Termo de Cooperação & $\begin{array}{l}\text { Manejo e Recuperação da Cobertura } \\
\text { Vegetal da Bacia do Mapou, Haiti }\end{array}$ & $30 / 11 / 2006$ & $\begin{array}{l}\text { Ruy Nunes } \\
\text { Pinto } \\
\text { Nogueira }\end{array}$ & $\begin{array}{l}\text { Subsecretário- } \\
\text { Geral de } \\
\text { Cooperação e } \\
\text { Comunidades } \\
\text { Brasileiras no } \\
\text { Exterior } \\
\end{array}$ \\
\hline
\end{tabular}




\begin{tabular}{|c|c|c|c|c|}
\hline $\begin{array}{l}\text { Memorando de } \\
\text { Entendimento }\end{array}$ & $\begin{array}{l}\text { Memorando de Entendimento entre o } \\
\text { Governo da República Federativa do } \\
\text { Brasil e a Organização Internacional do } \\
\text { Trabalho para o Estabelecimento da } \\
\text { Iniciativa de Cooperação Sul-Sul no } \\
\text { Combate ao Trabalho Infantil } \\
\end{array}$ & $14 / 12 / 2007$ & $\begin{array}{l}\text { Celso } \\
\text { Amorim }\end{array}$ & $\begin{array}{l}\text { Ministro das } \\
\text { Relações } \\
\text { Exteriores }\end{array}$ \\
\hline $\begin{array}{l}\text { Acordo de Cooperação } \\
\text { Técnica }\end{array}$ & Setor Educacional & $28 / 05 / 2008$ & $\begin{array}{l}\text { Celso } \\
\text { Amorim }\end{array}$ & $\begin{array}{l}\text { Ministro das } \\
\text { Relações } \\
\text { Exteriores }\end{array}$ \\
\hline $\begin{array}{l}\text { Acordo de Cooperação } \\
\text { Técnica }\end{array}$ & $\begin{array}{c}\text { Programa Estratégico de Cooperação } \\
\text { Técnica para o Período 2008-2010 nas } \\
\text { Áreas de Segurança Alimentar e de } \\
\text { Agricultura }\end{array}$ & $28 / 05 / 2008$ & $\begin{array}{l}\text { Celso } \\
\text { Amorim }\end{array}$ & $\begin{array}{l}\text { Ministro das } \\
\text { Relações } \\
\text { Exteriores }\end{array}$ \\
\hline Ajuste Complementar & $\begin{array}{l}\text { Prooção da Produção Sustentáve de } \\
\text { Hortaliças na Região de Kenscoff }\end{array}$ & $28 / 05 / 2008$ & $\begin{array}{l}\text { Celso } \\
\text { Amorim }\end{array}$ & $\begin{array}{l}\text { Ministro das } \\
\text { Relações } \\
\text { Exteriores }\end{array}$ \\
\hline Ajuste Complementar & Combate à Violência contra as Mulheres & $28 / 05 / 2008$ & $\begin{array}{l}\text { Celso } \\
\text { Amorim }\end{array}$ & $\begin{array}{l}\text { Ministro das } \\
\text { Relações } \\
\text { Exteriores } \\
\end{array}$ \\
\hline Ajuste Complementar & $\begin{array}{c}\text { Implementação do Programa Estratégico } \\
\text { 2008-2010 nas Áreas de Segurança } \\
\text { Alimentar e Agricultura }\end{array}$ & $20 / 12 / 2008$ & Igor Kipman & $\begin{array}{c}\text { Embaixador } \\
\text { Extraordinário } \\
\text { Plenipotenciário no } \\
\text { Haiti } \\
\end{array}$ \\
\hline Ajuste Complementar & $\begin{array}{l}\text { Formação de Multiplicadores em Técnicas } \\
\text { Policiais }\end{array}$ & $22 / 10 / 2009$ & Igor Kipman & $\begin{array}{c}\text { Embaixador } \\
\text { Extraordinário } \\
\text { Plenipotenciário no } \\
\text { Haiti }\end{array}$ \\
\hline Ajuste Complementar & $\begin{array}{l}\text { Estudo para a Formação de Ações de } \\
\text { Fortalecimento da Agricultura Familiar e } \\
\text { da Segurança Alimentar e Nutricional }\end{array}$ & $25 / 02 / 2010$ & $\begin{array}{l}\text { Patrus } \\
\text { Ananias }\end{array}$ & $\begin{array}{l}\text { Ministro do } \\
\text { Desenvolvimento } \\
\text { Social e Combate à } \\
\text { Fome }\end{array}$ \\
\hline Ajuste Complementar & $\begin{array}{c}\text { Modernização e Fortalecimento do } \\
\text { Centro-Piloto de Formação Profissional } \\
\text { Brasil-Haiti" }\end{array}$ & $25 / 02 / 2010$ & $\begin{array}{l}\text { Antonio } \\
\text { Patriota }\end{array}$ & $\begin{array}{l}\text { Secretário-Geral do } \\
\text { Ministério das } \\
\text { Relações } \\
\text { Exteriores }\end{array}$ \\
\hline Ajuste Complementar & $\begin{array}{c}\text { Construção de Cisternas para Captação e } \\
\text { Armazenamento de Água de Chuva no } \\
\text { Haiti }\end{array}$ & $25 / 02 / 2010$ & $\begin{array}{l}\text { Patrus } \\
\text { Ananias }\end{array}$ & $\begin{array}{l}\text { Ministro do } \\
\text { Desenvolvimento } \\
\text { Social e Combate à } \\
\text { Fome }\end{array}$ \\
\hline $\begin{array}{l}\text { Memorando de } \\
\text { Entendimento }\end{array}$ & $\begin{array}{l}\text { Memorando de Entendimento entre o } \\
\text { Governo da República Federativa do } \\
\text { Brasil e o Governo da República do Haiti } \\
\text { para a Reconstrução, o Fortalecimento e } \\
\text { Recomposição do Sistema de Educação } \\
\text { Superior do Haiti }\end{array}$ & $25 / 02 / 2010$ & $\begin{array}{l}\text { Antonio } \\
\text { Patriota }\end{array}$ & $\begin{array}{l}\text { Secretário-Geral do } \\
\text { Ministério das } \\
\text { Relações } \\
\text { Exteriores }\end{array}$ \\
\hline $\begin{array}{l}\text { Memorando de } \\
\text { Entendimento }\end{array}$ & $\begin{array}{c}\text { Memorando de Entendimento entre o } \\
\text { Governo da República Federativa do } \\
\text { Brasil e o Governo dos Estados Unidos da } \\
\text { América sobre a Implementação de } \\
\text { Atividades de Cooperação Técnica em } \\
\text { Terceiros Países }\end{array}$ & 03/03/2010 & $\begin{array}{l}\text { Celso } \\
\text { Amorim }\end{array}$ & $\begin{array}{l}\text { Ministro das } \\
\text { Relações } \\
\text { Exteriores }\end{array}$ \\
\hline $\begin{array}{l}\text { Memorando de } \\
\text { Entendimento }\end{array}$ & $\begin{array}{l}\text { Memorando de Entendimento entre o } \\
\text { Governo da República Federativa do } \\
\text { Brasil, o Governo da República de Cuba e } \\
\text { o Governo da República do Haiti para o } \\
\text { Fortalecimento do Sistema e dos Serviços } \\
\text { Públicos de Saúde e de Vigilância } \\
\text { Epidemiológica no Haiti }\end{array}$ & $27 / 03 / 2010$ & $\begin{array}{l}\text { José Gomes } \\
\text { Temporão }\end{array}$ & Ministro da Saúde \\
\hline Ajuste Complementar & $\begin{array}{l}\text { Projeto de Criação do Centro de Formação } \\
\text { Profissional no Domínio do Comércio e } \\
\text { dos Serviços (CFPCS) }\end{array}$ & $26 / 04 / 2010$ & $\begin{array}{l}\text { não } \\
\text { especificado }\end{array}$ & não especificado \\
\hline $\begin{array}{l}\text { Memorando de } \\
\text { Entendimento }\end{array}$ & $\begin{array}{c}\text { Memorando de Entendimento entre o } \\
\text { Governo da República Federativa do } \\
\text { Brasil e o Governo Da República } \\
\text { Dominicana sobre Cooperação Técnica } \\
\text { em Benefício da República do Haiti na } \\
\text { Área de Defesa Civil }\end{array}$ & $26 / 04 / 2010$ & $\begin{array}{l}\text { Antonio } \\
\text { Patriota }\end{array}$ & $\begin{array}{l}\text { Secretário-Geral do } \\
\text { Ministério das } \\
\text { Relações } \\
\text { Exteriores }\end{array}$ \\
\hline Ajuste Complementar & $\begin{array}{c}\text { Inserção Social pela Prática Esportiva em } \\
\text { Futebol }\end{array}$ & $20 / 09 / 2010$ & Igor Kipman & $\begin{array}{c}\text { Embaixador } \\
\text { Extraordinário } \\
\text { Plenipotenciário no } \\
\text { Haiti }\end{array}$ \\
\hline Ajuste Complementar & $\begin{array}{c}\text { Manejo e Reconstituição da Cobertura } \\
\text { Vegetal da Bacia do Mapou, Haiti: } \\
\text { Segunda Fase }\end{array}$ & $29 / 09 / 2010$ & $\begin{array}{l}\text { Celso } \\
\text { Amorim }\end{array}$ & $\begin{array}{l}\text { Ministro das } \\
\text { Relações } \\
\text { Exteriores } \\
\end{array}$ \\
\hline
\end{tabular}




\begin{tabular}{|c|c|c|c|c|}
\hline Ajuste Complementar & $\begin{array}{c}\text { Apoio à Implantação de Banco de Leite } \\
\text { Humano no Haiti }\end{array}$ & $29 / 09 / 2010$ & $\begin{array}{l}\text { Celso } \\
\text { Amorim }\end{array}$ & $\begin{array}{l}\text { Ministro das } \\
\text { Relações } \\
\text { Exteriores }\end{array}$ \\
\hline Ajuste Complementar & $\begin{array}{c}\text { Fortalecimento da Capacidade Política e } \\
\text { Institucional de Agentes Governamentais } \\
\text { e Não-Governamentais do Haiti para } \\
\text { Promoção e Defesa dos Direitos das } \\
\text { Pessoas com Deficiência }\end{array}$ & $29 / 09 / 2010$ & $\begin{array}{l}\text { Celso } \\
\text { Amorim }\end{array}$ & $\begin{array}{l}\text { Ministro das } \\
\text { Relações } \\
\text { Exteriores }\end{array}$ \\
\hline Ajuste Complementar & $\begin{array}{c}\text { Programa de Capacitação em Reabilitação } \\
\text { de Pessoas com Deficiência }\end{array}$ & $29 / 09 / 2010$ & $\begin{array}{l}\text { Celso } \\
\text { Amorim }\end{array}$ & $\begin{array}{l}\text { Ministro das } \\
\text { Relações } \\
\text { Exteriores }\end{array}$ \\
\hline Ajuste Complementar & $\begin{array}{l}\text { Capacitação, Modernização e Ampliação } \\
\text { da Capacidade Operacional do } \\
\text { Laboratório do Centro de Saúde Lucelia } \\
\text { Bontemps, em La Plaine - Haiti }\end{array}$ & $29 / 09 / 2010$ & $\begin{array}{l}\text { Celso } \\
\text { Amorim }\end{array}$ & $\begin{array}{l}\text { Ministro das } \\
\text { Relações } \\
\text { Exteriores }\end{array}$ \\
\hline Ajuste Complementar & $\begin{array}{c}\text { Capacitação Técnica para Formação de } \\
\text { Instrutores de Táticas Defensivas: Defesa } \\
\text { Pessoal Policial }\end{array}$ & $29 / 09 / 2010$ & $\begin{array}{l}\text { Celso } \\
\text { Amorim }\end{array}$ & $\begin{array}{l}\text { Ministro das } \\
\text { Relações } \\
\text { Exteriores }\end{array}$ \\
\hline Ajuste Complementar & $\begin{array}{l}\text { Fortalecimento Institucional do Sistema } \\
\text { Judiciário da República do Haiti }\end{array}$ & $29 / 09 / 2010$ & $\begin{array}{l}\text { Celso } \\
\text { Amorim }\end{array}$ & $\begin{array}{l}\text { Ministro das } \\
\text { Relações } \\
\text { Exteriores }\end{array}$ \\
\hline Ajuste Complementar & $\begin{array}{l}\text { Fortalecimento Institucional em Defesa } \\
\text { Civil }\end{array}$ & $29 / 09 / 2010$ & $\begin{array}{l}\text { Celso } \\
\text { Amorim }\end{array}$ & $\begin{array}{l}\text { Ministro das } \\
\text { Relações } \\
\text { Exteriores }\end{array}$ \\
\hline Ajuste Complementar & $\begin{array}{c}\text { Instituto Haiti-Brasil de Reabilitação de } \\
\text { Pessoas com Deficiência }\end{array}$ & $29 / 09 / 2010$ & $\begin{array}{l}\text { Celso } \\
\text { Amorim }\end{array}$ & $\begin{array}{l}\text { Ministro das } \\
\text { Relações } \\
\text { Exteriores }\end{array}$ \\
\hline Ajuste Complementar & $\begin{array}{l}\text { Capacitação para a Elaboração de Políticas } \\
\text { Públicas de Museus por meio da } \\
\text { Reconstrução do Museu de Arte Haitiano } \\
\text { do Colégio de Saint-Pierre }\end{array}$ & $29 / 09 / 2010$ & $\begin{array}{l}\text { Celso } \\
\text { Amorim }\end{array}$ & $\begin{array}{l}\text { Ministro das } \\
\text { Relações } \\
\text { Exteriores }\end{array}$ \\
\hline $\begin{array}{l}\text { Memorando de } \\
\text { Entendimento }\end{array}$ & $\begin{array}{l}\text { Memorando de Entendimento entre o } \\
\text { Governo da República Federativa do } \\
\text { Brasil e o Programa das Nações Unidas } \\
\text { para o Desenvolvimento sobre Partilha de } \\
\text { Custos Relativos à Terceira Parte }\end{array}$ & $29 / 09 / 2010$ & $\begin{array}{l}\text { Celso } \\
\text { Amorim }\end{array}$ & $\begin{array}{l}\text { Ministro das } \\
\text { Relações } \\
\text { Exteriores }\end{array}$ \\
\hline
\end{tabular}

Fonte: Sistema Consular Integrado - Sistema de Atos Internacionais (SCI). Disponível em: http://daimre.serpro.gov.br/ (Acesso em 04 de novembro de 2014). 


\section{ANEXO 2}

\begin{tabular}{|c|c|c|c|c|}
\hline \multicolumn{5}{|c|}{ Projetos de Cooperação Técnica com o Haiti (2005 - 2010) } \\
\hline Código $A B C$ & Título do Projeto & $\begin{array}{l}\text { Data de } \\
\text { Início }\end{array}$ & $\begin{array}{l}\text { Data de } \\
\text { Conclusão }\end{array}$ & $\begin{array}{c}\text { Instituições Executoras } \\
\text { Brasileiras }\end{array}$ \\
\hline BRA/04/043-S001 & $\begin{array}{c}\text { Transferência de Tecnologias em } \\
\text { Sistema de Produção e Processamento } \\
\text { de Caju para o Haiti }\end{array}$ & $01 / 01 / 2005$ & $30 / 12 / 2007$ & $\begin{array}{l}\text { Empresa Brasileira de } \\
\text { Pesquisa Agropecuária } \\
\text { (EMBRAPA) }\end{array}$ \\
\hline BRA/04/043-S002 & $\begin{array}{l}\text { Desenvolvimento da Cultura da } \\
\text { Mandioca no Haiti }\end{array}$ & $01 / 01 / 2005$ & $31 / 10 / 2005$ & $\begin{array}{l}\text { Empresa Brasileira de } \\
\text { Pesquisa Agropecuária } \\
\text { (EMBRAPA) }\end{array}$ \\
\hline BRA/04/043-S014 & $\begin{array}{l}\text { Implementação da Participação do } \\
\text { Brasil no Âmbito do Acordo entre a } \\
\text { República Federativa do Brasil e o } \\
\text { Banco Mundial para a Execução do } \\
\text { Projeto Solid Waste Management } \\
\text { Strategy }\end{array}$ & $01 / 02 / 2005$ & $30 / 06 / 2009$ & sem inf \\
\hline BRA/04/043-S015 & $\begin{array}{l}\text { Implementação da participação do } \\
\text { Brasil no âmbito do acordo entre a } \\
\text { República Federativa do Brasil e o } \\
\text { Banco Mundial para a execução do } \\
\text { Projeto Haiti Building Institutional } \\
\text { Capacity and Strengthening Provision } \\
\text { of School Feeding Program }\end{array}$ & $01 / 02 / 2005$ & $31 / 12 / 2005$ & sem inf \\
\hline BRA/98/004-A041 & Capacitação Técnica em defesa Civil & $02 / 04 / 2005$ & $20 / 04 / 2005$ & Ministério da Integração \\
\hline BRA/04/043-A002 & $\begin{array}{c}\text { Proposta de Cooperação Técnica junto } \\
\text { ao Governo do Haiti Para } \\
\text { Reestruturação dos Serviços de } \\
\text { Imunização }\end{array}$ & $19 / 07 / 2005$ & 03/08/2005 & Ministério da Saúde \\
\hline BRA/98/004-A045 & $\begin{array}{l}\text { Apoio ao Instituto Nacional de } \\
\text { Formação Profissional do Haiti: } \\
\text { Formulação de Projeto para o Centro de } \\
\text { Formação Profissional de Jacmel }\end{array}$ & $23 / 07 / 2005$ & $30 / 07 / 2005$ & $\begin{array}{l}\text { Serviço Nacional de } \\
\text { aprendizagem Industrial } \\
\text { (SENAI) }\end{array}$ \\
\hline BRA/04/043-A001 & $\begin{array}{l}\text { Desenvolvimento agro-industrial sucro- } \\
\text { alcooleiro do Departamento do Norte } \\
\text { (Cap Haitien) do Haiti }\end{array}$ & $30 / 07 / 2005$ & $05 / 08 / 2005$ & $\begin{array}{l}\text { Faculdade de Ciências } \\
\text { Agronômicas da } \\
\text { Universidade do Estado } \\
\text { de São Paulo (USP) }\end{array}$ \\
\hline BRA/04/043-A009 & $\begin{array}{l}\text { Reciclagem Operacional para } \\
\text { Bombeiros em Contra-Incêndio e } \\
\text { Salvamento em Aeródromos }\end{array}$ & $15 / 01 / 2006$ & $31 / 03 / 2006$ & $\begin{array}{l}\text { Empresa Brasileira de } \\
\text { Infra-estrutura } \\
\text { Aeroportuária } \\
\text { (INFRAERO) }\end{array}$ \\
\hline sem inf & $\begin{array}{l}\text { Recuperação de infraestrutura } \\
\text { rodoviária da zona metropolitana de } \\
\text { Porto Príncipe, Haiti - Fase I }\end{array}$ & $02 / 2006$ & $04 / 2007$ & sem inf \\
\hline BRA/04/043-A020 & $\begin{array}{l}\text { Capacitação de Técnicos haitianos em } \\
\text { construção de cisternas na Embrapa } \\
\text { Semi-Árido(Petrolina-PE) }\end{array}$ & 09/08/2006 & $10 / 09 / 2006$ & $\begin{array}{l}\text { Empresa Brasileira de } \\
\text { Pesquisa Agropecuária } \\
\text { (EMBRAPA) }\end{array}$ \\
\hline BRA/04/043-A025 & $\begin{array}{l}\text { Capacitação em Software Livre e } \\
\text { Instalação de Telecentro Comunitário }\end{array}$ & $19 / 09 / 2006$ & $20 / 09 / 2006$ & $\begin{array}{c}\text { Serviço de } \\
\text { Processamento de Dados } \\
\text { (SERPRO) }\end{array}$ \\
\hline BRA/04/043-S020 & $\begin{array}{l}\text { Construção de Cisternas Familiares e } \\
\text { Validação Social de Cultivares de } \\
\text { Hortaliças no Haiti }\end{array}$ & $27 / 09 / 2006$ & $30 / 03 / 2008$ & $\begin{array}{l}\text { Empresa Brasileira de } \\
\text { Pesquisa Agropecuária } \\
\text { (EMBRAPA) }\end{array}$ \\
\hline
\end{tabular}




\begin{tabular}{|c|c|c|c|c|}
\hline BRA/04/043-S021 & $\begin{array}{c}\text { Sub-project to Support the Organization } \\
\text { of Local and Legislative Elections in } \\
\text { Haiti }\end{array}$ & $30 / 11 / 2006$ & $01 / 03 / 2007$ & sem inf \\
\hline BRA/04/043-S038 & $\begin{array}{l}\text { Manejo e Reconstituição da Cobertura } \\
\text { Vegetal da Bacia do Mapou, Haiti }\end{array}$ & $27 / 04 / 2007$ & $27 / 04 / 2009$ & $\begin{array}{c}\text { Universidade Federal } \\
\text { Rural do Rio de Janeiro } \\
\text { (UFRRJ) }\end{array}$ \\
\hline sem inf & $\begin{array}{l}\text { Recuperação de infraestrutura } \\
\text { rodoviária da zona metropolitana de } \\
\text { Porto Príncipe, Haiti - Fase II }\end{array}$ & $05 / 07$ & $12 / 2011$ & sem inf \\
\hline BRA/04/043-A047 & $\begin{array}{l}\text { Intercâmbio de conhecimentos na área } \\
\text { de segurança alimentar e nutricional }\end{array}$ & 01/07/2007 & $10 / 07 / 2007$ & $\begin{array}{l}\text { EMBRAPA Sede - } \\
\text { EMBRAPA }\end{array}$ \\
\hline sem inf & $\begin{array}{l}\text { Combate à violência contra as mulheres } \\
\text { no Haiti }\end{array}$ & $01 / 08 / 2007$ & 01/08/2009 & $\begin{array}{l}\text { Ministério da Saúde } \\
\text { (Brasil) - MS \| } \\
\text { Secretaria de Políticas } \\
\text { para as Mulheres - } \\
\text { SEPM/PR }\end{array}$ \\
\hline HAI/07/02/BRA & $\begin{array}{l}\text { Eliminação e prevenção das piores } \\
\text { formas de trabalho infantil no Haiti/ } \\
\text { Cooperação Técnica para Proteção de } \\
\text { Crianças contra o Trabalho Infantil - } \\
\text { BRASIL-OIT-HAITI }\end{array}$ & $23 / 11 / 2007$ & $31 / 12 / 2010$ & $\begin{array}{l}\text { Ministério do Trabalho e } \\
\text { Emprego }\end{array}$ \\
\hline BRA/04/043-S057 & $\begin{array}{c}\text { Promoção da Sustentabilidade da } \\
\text { Produção de Hortaliças na Região de } \\
\text { Kenscoff, Haiti }\end{array}$ & $29 / 07 / 2008$ & $31 / 07 / 2011$ & $\begin{array}{l}\text { Empresa Brasileira de } \\
\text { Pesquisa Agropecuária } \\
\text { (EMBRAPA) }\end{array}$ \\
\hline BRA/04/044-A260 & $\begin{array}{c}\text { Curso em tecnologia de produção de } \\
\text { sementes orgânicas de hortaliças com a } \\
\text { participação de técnicos da Nicarágua e } \\
\text { do Haiti }\end{array}$ & $10 / 10 / 2008$ & 10/04/2009 & $\begin{array}{l}\text { Coordenaçãa-Geral de } \\
\text { Ações Internacionais de } \\
\text { Combate à Fome } \\
\text { (CGFOME) }\end{array}$ \\
\hline BRA/IICA/ABC/09/01 & $\begin{array}{l}\text { Revitalização da Fazenda do Ministério } \\
\text { da Agricultura, Recursos Naturais e } \\
\text { Desenvolvimento Rural do Haiti } \\
\text { (MARNDR) em Fond des Nègres }\end{array}$ & 05/03/2009 & 01/01/2014 & $\begin{array}{l}\text { Empresa Brasileira de } \\
\text { Pesquisa Agropecuária } \\
\text { (EMBRAPA) }\end{array}$ \\
\hline BRA/IICA/ABC/09/03 & $\begin{array}{l}\text { Estudo para a promoção de ações de } \\
\text { fortalecimento da agricultura familiar e } \\
\text { da segurança alimentar e nutricional }\end{array}$ & $20 / 10 / 2009$ & $31 / 08 / 2012$ & sem inf \\
\hline BRA/04/044-A475 & $\begin{array}{l}\text { Apoio às Iniciativas de Proteção da } \\
\text { Criança no Haiti Pastoral da Criança }\end{array}$ & $13 / 05 / 2010$ & $23 / 12 / 2010$ & $\begin{array}{l}\text { Pastoral da Criança do } \\
\text { Brasil - PC }\end{array}$ \\
\hline sem inf & $\begin{array}{c}\text { Capacitação da Polícia Nacional } \\
\text { Haitiana - PNH fase II (Armamento e } \\
\text { Tiro) }\end{array}$ & $07 / 2010$ & $10 / 2010$ & sem inf \\
\hline BRA/04/044-A566 & $\begin{array}{l}\text { PROGRAMA DE COOPERAÇÃO } \\
\text { BRASIL-HAITI PÓS-TERREMOTO: } \\
\text { INCLUSÃO SOCIAL DE PESSOAS } \\
\text { COM DEFICIÊNCIA }\end{array}$ & 05/08/2010 & $31 / 12 / 2010$ & $\begin{array}{c}\text { Ministério da Saúde } \\
\text { Secretaria de Direitos } \\
\text { Humanos da Presidência } \\
\text { da República - SDH/PR }\end{array}$ \\
\hline BRA/04/044-S226 & $\begin{array}{l}\text { Capacitação Técnica para Formação } \\
\text { Instrutores de Armamento e Tiro }\end{array}$ & $13 / 07 / 2010$ & $13 / 10 / 2010$ & Polícia Federal - PF \\
\hline BRA/04/044-A604 & $\begin{array}{c}\text { Apoio às Iniciativas de Proteção da } \\
\text { Criança no Haiti - Pastoral da criança - } \\
\text { Fase } 2\end{array}$ & $17 / 09 / 2010$ & $23 / 12 / 2010$ & $\begin{array}{l}\text { Pastoral da Criança do } \\
\text { Brasil - PC }\end{array}$ \\
\hline S294 & $\begin{array}{c}\text { Inclusão social por meio da prática } \\
\text { esportiva }\end{array}$ & 20/09/2010 & $20 / 11 / 2011$ & Ole Brasil Futebol Clube \\
\hline BRA/04/044-S278 & $\begin{array}{c}\text { Capacitação Técnica para Formação de } \\
\text { Instrutores de Táticas Defensivas: } \\
\text { Defesa Pessoal Policial }\end{array}$ & $04 / 10 / 2010$ & $04 / 10 / 2012$ & $\begin{array}{l}\text { Departamento da Polícia } \\
\text { Federal - DPF/MJ }\end{array}$ \\
\hline BRA/04/044-A622 & $\begin{array}{l}\text { Capacitação de Profissionais de Saúde } \\
\text { Haitianos em Técnicas de Tratamento e } \\
\text { Prevenção do Cólera }\end{array}$ & $28 / 10 / 2010$ & 01/07/2011 & $\begin{array}{l}\text { Sociedade Beneficente } \\
\text { Israelita Brasileira } \\
\text { Hospital Albert Einstein } \\
\text { - SBIBHAE }\end{array}$ \\
\hline
\end{tabular}




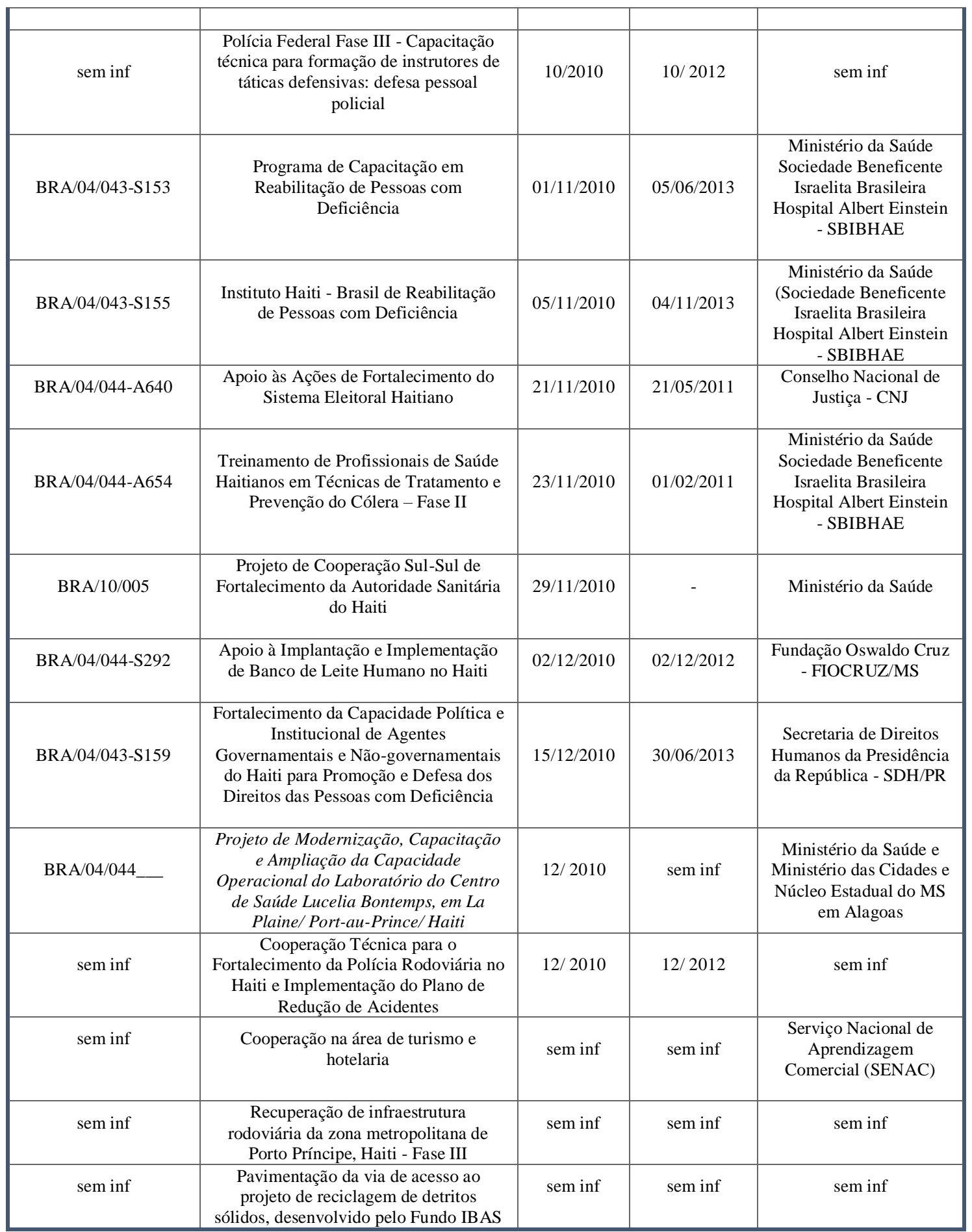

Fonte: site da ABC. Disponível em: http://www.abc.gov.br/ (Acesso em 10 de outubro de 2014). 


\section{ANEXO 3}

\begin{tabular}{|c|c|c|c|}
\hline Código $A B C$ & Título da Missão & $\begin{array}{l}\text { Data de } \\
\text { Início }\end{array}$ & $\begin{array}{c}\text { Data de } \\
\text { Conclusão }\end{array}$ \\
\hline $\begin{array}{l}\text { BRA/98/004- } \\
\quad \text { A038 }\end{array}$ & $\begin{array}{c}\text { Missão de Prospecção ao Haiti na Àrea de Infra-estrutura } \\
\text { Aeroportuária }\end{array}$ & $04 / 11 / 2004$ & $11 / 12 / 2004$ \\
\hline $\begin{array}{l}\text { BRA/04/043- } \\
\quad \text { A008 }\end{array}$ & $\begin{array}{l}\text { Observação do projeto eleitoral haitiano com vistas a } \\
\text { identificar áreas de cooperação técnica brasileira em matéria } \\
\text { eleitoral }\end{array}$ & $01 / 12 / 2005$ & $31 / 01 / 2006$ \\
\hline $\begin{array}{l}\text { BRA/04/043- } \\
\quad \text { A017 }\end{array}$ & $\begin{array}{c}\text { Missão de prospecção de técnicos brasileiros da Embrapa } \\
\text { Hortaliças (Brasília-DF) e da Embrapa Semi-Árido (Petrolina- } \\
\text { PE) ao Haiti com vistas a elaborar projeto de cooperação } \\
\text { técnica }\end{array}$ & 20/07/2006 & $10 / 08 / 2006$ \\
\hline $\begin{array}{l}\text { BRA/04/043- } \\
\quad \text { A019 }\end{array}$ & $\begin{array}{l}\text { Missão de prospecção e capacitação de técnicos haitianos à } \\
\text { Reunião da Comunidade Sul-Americana de Nações sobre } \\
\text { Biocombustíveis na Perspectiva Sócio-Ambiental }\end{array}$ & $10 / 08 / 2006$ & $25 / 08 / 2006$ \\
\hline $\begin{array}{l}\text { BRA/04/043- } \\
\quad \text { A038 }\end{array}$ & $\begin{array}{l}\text { Proposta de cooperação técnica junto ao Governo do Haiti } \\
\text { para a reconstituição da cobertura vegetal da Bacia do Mapou }\end{array}$ & $10 / 04 / 2007$ & $10 / 05 / 2007$ \\
\hline $\begin{array}{l}\text { BRA/04/043- } \\
\quad \text { A051 }\end{array}$ & $\begin{array}{c}\text { Missão de apoio a cooperação técnica trilateral Brasil - Haiti - } \\
\text { Canadá na área de imunizações }\end{array}$ & $20 / 07 / 2007$ & $20 / 08 / 2007$ \\
\hline $\begin{array}{l}\text { BRA/04/043- } \\
\quad \text { A050 }\end{array}$ & $\begin{array}{l}\text { Missão de prospecção para elaboração de proposta de } \\
\text { cooperação técnica para o incremento da produção de } \\
\text { hortaliças na região de Kenscoff, Haiti }\end{array}$ & 01/08/2007 & $15 / 09 / 2007$ \\
\hline $\begin{array}{l}\text { BRA/04/043 - } \\
\quad \text { S037 }\end{array}$ & $\begin{array}{c}\text { Implementação da participação brasileira no âmbito do } \\
\text { Acordo entre a República Federativa do Brasil e o Banco } \\
\text { Mundial para a Execução do Projeto Haiti Building } \\
\text { Institutional Capacity and Strengthening Provision of School } \\
\text { Feeding Program }\end{array}$ & 27/09/2007 & $31 / 12 / 2008$ \\
\hline $\begin{array}{l}\text { BRA/04/043- } \\
\quad \text { S037 }\end{array}$ & $\begin{array}{c}\text { Implementação da participação brasileira no âmbito do } \\
\text { Acordo entre a República Federativa do Brasil e o Banco } \\
\text { Mundial para a Execução do Projeto Haiti Building } \\
\text { Institutional Capacity and Strengthening Provision of School } \\
\text { Feeding Program }\end{array}$ & 01/10/2007 & $01 / 10 / 2008$ \\
\hline $\begin{array}{l}\text { BRA/04/043- } \\
\quad \text { A077 }\end{array}$ & $\begin{array}{c}\text { Missão para elaboração de propostas de cooperação técnica na } \\
\text { área de educação em benefício do Haiti }\end{array}$ & 07/04/2008 & $26 / 04 / 2008$ \\
\hline $\begin{array}{l}\text { BRA/04/043- } \\
\quad \text { A081 }\end{array}$ & $\begin{array}{c}\text { Missão de prospeção para elaboração de projeto de } \\
\text { cooperação técnica na área de educação profissional em } \\
\text { benefício do Haiti }\end{array}$ & 05/05/2008 & $01 / 11 / 2008$ \\
\hline $\begin{array}{l}\text { BRA/04/043- } \\
\text { A087 }\end{array}$ & $\begin{array}{c}\text { Missão de apoio à inserção da prática da rizipiscicultura no } \\
\text { Haiti e na Nicarágua }\end{array}$ & $20 / 05 / 2008$ & $21 / 06 / 2008$ \\
\hline $\begin{array}{l}\text { BRA/04/043- } \\
\quad \text { A092 }\end{array}$ & $\begin{array}{l}\text { Missão de representantes do Conselho Eleitoral Provisório } \\
\text { haitiano ao Tribunal Superior Eleitoral do Brasil }\end{array}$ & $19 / 06 / 2008$ & $29 / 07 / 2008$ \\
\hline $\begin{array}{l}\text { BRA/04/043- } \\
\quad \text { A094 }\end{array}$ & $\begin{array}{l}\text { Missão de especialistas brasileiros para elaboração do } \\
\text { Programa de Cooperação Técnica 2008-2010 em benefício do } \\
\text { Haiti nas áreas de segurança alimentar e de agricultura }\end{array}$ & 03/07/2008 & 03/09/2008 \\
\hline $\begin{array}{l}\text { BRA/04/043- } \\
\quad \text { A099 }\end{array}$ & $\begin{array}{c}\text { Missão de prospecção para estudo de viabilidade de } \\
\text { construção de barragens no Haiti }\end{array}$ & $15 / 07 / 2008$ & $15 / 08 / 2008$ \\
\hline $\begin{array}{l}\text { BRA/04/043- } \\
\quad \text { A103 }\end{array}$ & $\begin{array}{l}\text { Missão de especialistas haitianos para finalização do } \\
\text { Programa de Cooperação Técnica 2008-2010 nas áreas de } \\
\text { segurança alimentar e de agricultura }\end{array}$ & $18 / 08 / 2008$ & $18 / 10 / 2008$ \\
\hline $\begin{array}{l}\text { BRA/04/043 - } \\
\quad \text { A118 }\end{array}$ & $\begin{array}{c}\text { Participação de representantes haitianos no III Congresso } \\
\text { Mundial de Enfrentamento da Exploração Sexual de Crianças } \\
\text { e Adolescentes }\end{array}$ & $14 / 11 / 2008$ & $30 / 11 / 2008$ \\
\hline $\begin{array}{l}\text { BRA/04/043- } \\
\quad \text { A132 }\end{array}$ & $\begin{array}{c}\text { Missão técnica para levantamento de propostas para } \\
\text { operacionalizar a cooperação técnica no Haiti nas áreas de } \\
\text { agricultura e segurança alimentar }\end{array}$ & $18 / 11 / 2008$ & $30 / 12 / 2008$ \\
\hline $\begin{array}{l}\text { BRA/98/004 - } \\
\text { A080 }\end{array}$ & $\begin{array}{l}\text { Missão de prospecção para elaboração de projeto de } \\
\text { revitalização da Fazenda Fond des Nègres no Haiti }\end{array}$ & $20 / 11 / 2008$ & $05 / 12 / 2008$ \\
\hline $\begin{array}{l}\text { BRA/04/043- } \\
\text { A156 }\end{array}$ & $\begin{array}{l}\text { Missão de Prospecção de projeto sobre sistemas de Captação } \\
\text { de água de chuva para consumo humano e irrigação no Haiti }\end{array}$ & $15 / 01 / 2009$ & $31 / 03 / 2009$ \\
\hline $\begin{array}{l}\text { BRA/04/043- } \\
\quad \text { A153 }\end{array}$ & $\begin{array}{c}\text { Missão de prospecção de projetos nas áreas de aquisição e } \\
\text { distribuição de alimentos e fortalecimento da agricultura } \\
\text { familiar no Haiti }\end{array}$ & $15 / 01 / 2009$ & $31 / 03 / 2009$ \\
\hline $\begin{array}{l}\text { BRA/04/043 - } \\
\quad \text { A131 }\end{array}$ & $\begin{array}{l}\text { Missão de prospecção para levantamento de dados e análise } \\
\text { mercadológica da economia agrícola, no Haiti }\end{array}$ & $15 / 01 / 2009$ & $19 / 02 / 2009$ \\
\hline
\end{tabular}




\begin{tabular}{|c|c|c|c|}
\hline $\begin{array}{l}\text { BRA/04/043- } \\
\text { A161 }\end{array}$ & $\begin{array}{l}\text { Missão de Prospecção de projeto para implementação de } \\
\text { Centro de Formação Profissional no Haiti }\end{array}$ & 26/01/2009 & $30 / 06 / 2009$ \\
\hline $\begin{array}{l}\text { BRA/04/043- } \\
\text { A174 }\end{array}$ & $\begin{array}{l}\text { Missão de Prospecção de projeto para implementação de um } \\
\text { Restaurante-Escola no Haiti }\end{array}$ & $10 / 02 / 2009$ & $30 / 06 / 2009$ \\
\hline $\begin{array}{l}\text { BRA/04/043- } \\
\text { A176 }\end{array}$ & $\begin{array}{c}\text { Missão de Prospecção de projeto na área de ações de } \\
\text { Desenvolvimento Comunitário no Haiti }\end{array}$ & $10 / 02 / 2009$ & $30 / 05 / 2009$ \\
\hline $\begin{array}{l}\text { BRA/04/043- } \\
\text { Cotton } 4 \text { + Haiti }\end{array}$ & $\begin{array}{l}\text { Missão para Reunião sobre o Projeto Cotton-4 e início das } \\
\text { atividades do Projeto de Revitalização da Fazenda de Fond- } \\
\text { des-Nègres }\end{array}$ & 01/04/2009 & $10 / 05 / 2009$ \\
\hline $\begin{array}{l}\text { BRA/04/043- } \\
\quad \text { A229 }\end{array}$ & $\begin{array}{c}\text { Missão para definição de mecanismos de operacionalização } \\
\text { entre ABC e IICA para início da execução do projeto de } \\
\text { Revitalização da Fazenda de Fond-des-Nègres }\end{array}$ & $01 / 04 / 2009$ & $30 / 06 / 2009$ \\
\hline $\begin{array}{l}\text { BRA/04/043- } \\
\text { Fond-des- } \\
\text { Nègres }\end{array}$ & $\begin{array}{c}\text { Missão de acompanhamento do processo de Revitalização da } \\
\text { Fazenda de Fond-des-Nègres - Haiti - para a implementação } \\
\text { de uma Unidade de Demonstração e Validação de } \\
\text { Tecnologias Agrícolas }\end{array}$ & $15 / 05 / 2009$ & $30 / 08 / 2009$ \\
\hline $\begin{array}{l}\text { BRA/04/043- } \\
\quad \mathrm{A} 285\end{array}$ & $\begin{array}{c}\text { Missão de Prospecção para implementação da segunda fase } \\
\text { do Projeto de Transferência de Tecnologias de Produção e } \\
\text { Processamento de Castanha de Caju no Haiti. }\end{array}$ & $25 / 05 / 2009$ & $31 / 10 / 2009$ \\
\hline $\begin{array}{l}\mathrm{BRA} / 04 / 043- \\
\quad \mathrm{A} 276\end{array}$ & $\begin{array}{l}\text { Missão do Diretor-Geral do Ministério da Agricultura do } \\
\text { Haiti e de representante do IICA ao Brasil para fortalecimento } \\
\text { da cooperação nas áreas de tecnologia agrícola, extensão rural } \\
\text { e segurança alimentar. }\end{array}$ & $26 / 05 / 2009$ & $31 / 08 / 2009$ \\
\hline $\begin{array}{l}\text { BRA/04/043- } \\
\text { Banco de Leite } \\
\text { Hait }\end{array}$ & $\begin{array}{l}\text { Missão de especialistas da Fundação Oswaldo Cruz (Fiocruz) } \\
\text { para elaboração de proposta de projeto de cooperação técnica } \\
\text { para implantação de redes de banco de leite humano no Haiti }\end{array}$ & $25 / 06 / 2009$ & $30 / 09 / 2009$ \\
\hline $\begin{array}{l}\text { BRA/04/044- } \\
\text { A291 }\end{array}$ & Missão de Prospecção na área de segurança pública & $15 / 10 / 2009$ & $15 / 12 / 2009$ \\
\hline $\begin{array}{l}\text { BRA/04/044- } \\
\quad \text { A309 }\end{array}$ & $\begin{array}{c}\text { Missão para finalização do projeto "Desenvolvimento da } \\
\text { cajucultura no Haiti: formação de pomares e beneficiamento } \\
\text { da castanha de caju" }\end{array}$ & $02 / 11 / 2009$ & $15 / 12 / 2009$ \\
\hline $\begin{array}{l}\text { BRA/04/044- } \\
\text { A312 }\end{array}$ & $\begin{array}{l}\text { Missão de Avaliação e Prospecção de Projetos no Haiti - } \\
\text { Novembro } 2009\end{array}$ & $10 / 11 / 2009$ & $10 / 12 / 2009$ \\
\hline $\begin{array}{l}\text { BRA/04/044- } \\
\text { A322 }\end{array}$ & $\begin{array}{l}\text { Participação na Conferência sobre Agricultura do Educational } \\
\text { Concerns For Hunger Organization (ECHO). }\end{array}$ & $13 / 11 / 2009$ & $15 / 02 / 2010$ \\
\hline $\begin{array}{l}\text { BRA/04/044- } \\
\text { A333 }\end{array}$ & $\begin{array}{c}\text { Participação de Especialistas Brasileiros no Debate sobre a } \\
\text { Experiência da Pastoral da Criança }\end{array}$ & $08 / 12 / 2009$ & 08/03/2010 \\
\hline $\begin{array}{l}\text { BRA/04/044- } \\
\quad \text { A357 }\end{array}$ & $\begin{array}{c}\text { Visita Técnica de Funcionário da Prefeitura de Salvador para } \\
\text { Elaboração de Projetos de Cooperação Brasil-Haiti }\end{array}$ & $27 / 01 / 2010$ & $20 / 09 / 2010$ \\
\hline $\begin{array}{l}\text { BRA/04/044- } \\
\quad \text { A383 }\end{array}$ & $\begin{array}{l}\text { Programa de Cooperação Brasil-Haiti Pós-Terremoto. } \\
\text { Identificação de Condições in loco para Retomada da } \\
\text { Cooperação e Detalhamento de Novas Demandas nas Áreas } \\
\text { de Agricultura, Educação/Formação Profissional, Saúde e } \\
\text { Inclusão Social }\end{array}$ & $22 / 02 / 2010$ & $31 / 12 / 2010$ \\
\hline $\begin{array}{l}\text { BRA/04/044- } \\
\quad \text { A413 }\end{array}$ & Programa Brasil-Haiti de Cooperação. CARICOM & $15 / 03 / 2010$ & $30 / 03 / 2010$ \\
\hline $\begin{array}{l}\text { BRA/04/044- } \\
\quad \text { A412 }\end{array}$ & $\begin{array}{l}\text { Programa de Cooperação Brasil-Haiti Pós-Terremoto. } \\
\text { Identificação de Condições In Loco para Retomada da } \\
\text { Cooperação e Detalhamento de Novas Demandas nas Áreas: } \\
\text { Tecnologias de Construção de Baixo Custo, Saneamento, } \\
\text { Fortalecimento Institucional, Esportes e Cidadania }\end{array}$ & $15 / 03 / 2010$ & $31 / 12 / 2010$ \\
\hline $\begin{array}{l}\text { BRA/04/044- } \\
\quad \text { A449 }\end{array}$ & $\begin{array}{c}\text { Aquisição de imagem orbital para viabilizar a elaboração da } \\
\text { proposta de segunda fase do projeto "Manejo e Reconstituição } \\
\text { da Cobertura Vegetal da Bacia do Mapou, Haiti" e do Plano } \\
\text { de Proteção e Restauração da floresta de Pinus }\end{array}$ & $15 / 04 / 2010$ & $15 / 10 / 2010$ \\
\hline $\begin{array}{l}\text { BRA/04/044- } \\
\text { SEMINARIO } \\
\text { FR-BR }\end{array}$ & $\begin{array}{c}\text { Seminário "Para uma Cooperação Cruzada Franco-Brasileira } \\
\text { no Haiti e na África" }\end{array}$ & $24 / 05 / 2010$ & $30 / 08 / 2010$ \\
\hline $\begin{array}{l}\text { BRA/04/044- } \\
\text { A486 }\end{array}$ & $\begin{array}{c}\text { Participação de Técnicos Brasileiros na Cúpula Mundial sobre } \\
\text { o Futuro do Haiti }\end{array}$ & $24 / 05 / 2010$ & $02 / 11 / 2010$ \\
\hline $\begin{array}{l}\text { BRA/04/044- } \\
\text { A } 488\end{array}$ & $\begin{array}{c}\text { Missão de delegação do Haiti ao Brasil no contexto da } \\
\text { "Conferência Internacional Infanto-juvenil: Vamos Cuidar do } \\
\text { Planeta" }\end{array}$ & $24 / 05 / 2010$ & $30 / 06 / 2010$ \\
\hline $\begin{array}{l}\text { BRA/04/044- } \\
\text { OléBrasil }\end{array}$ & $\begin{array}{l}\text { Missão para negociação de projeto na área de inclusão social } \\
\text { por meio da prática esportiva. }\end{array}$ & $25 / 05 / 2010$ & $24 / 08 / 2010$ \\
\hline $\begin{array}{l}\text { BRA/04/044- } \\
\quad \text { A5 } 16\end{array}$ & $\begin{array}{c}\text { Apoio à Participação de Representantes do Ministério das } \\
\text { Comunicações e da Agência Nacional de Telecomunicações - } \\
\text { ANATEL na Mesa Redonda sobre Reconstrução do Setor de } \\
\text { Telecomunicações do Haiti }\end{array}$ & $10 / 06 / 2010$ & $23 / 10 / 2010$ \\
\hline $\begin{array}{l}\text { BRA/04/044- } \\
\text { A503 }\end{array}$ & $\begin{array}{l}\text { Missão de Avaliação e Acompanhamento do Projeto de } \\
\text { Revitalização da Fazenda de Fond-des-Nègres - Haiti }\end{array}$ & $15 / 06 / 2010$ & $30 / 07 / 2010$ \\
\hline $\begin{array}{l}\text { BRA/04/044- } \\
\quad \text { A532 }\end{array}$ & $\begin{array}{l}\text { Missão de Técnicos da Polícia Federal para Coordenação de } \\
\text { Atividades de Capacitação no Haiti }\end{array}$ & $01 / 07 / 2010$ & $31 / 12 / 2010$ \\
\hline
\end{tabular}




\begin{tabular}{|c|c|c|c|}
\hline $\begin{array}{l}\text { BRA/04/044- } \\
\text { A559 }\end{array}$ & $\begin{array}{l}\text { Missão institucional para prospecção de projeto de } \\
\text { capacitação em matéria de defesa civil }\end{array}$ & 02/08/2010 & $01 / 11 / 2010$ \\
\hline $\begin{array}{l}\text { BRA/04/044 - } \\
\quad \text { A603 }\end{array}$ & $\begin{array}{c}\text { Missão de prospecção da Globoaves (Kaefer Administração e } \\
\text { Participações S.A.) para elaboração de projeto na área de } \\
\text { produção de aves coloniais em benefício do Haiti e sua } \\
\text { população }\end{array}$ & $14 / 09 / 2010$ & $14 / 12 / 2010$ \\
\hline $\begin{array}{l}\text { BRA/04/044- } \\
\quad \text { A605 }\end{array}$ & $\begin{array}{c}\text { Missão de representantes do Instituto Haitiano de Estatística } \\
\text { (IHS) ao Brasil para elaboração de proposta de projeto, em } \\
\text { parceria com o IBGE, na área de pesquisa populacional das } \\
\text { pessoas com deficiência }\end{array}$ & $16 / 09 / 2010$ & $16 / 03 / 2011$ \\
\hline BRA/04/044- & $\begin{array}{c}\text { Missão para apoio ao Núcleo de Cooperação da Embaixada } \\
\text { Brasileira em Porto Príncipe }\end{array}$ & $17 / 09 / 2010$ & $17 / 11 / 2010$ \\
\hline
\end{tabular}

Fonte: site da ABC. Disponível em: http://www.abc.gov.br/ (Acesso em 10 de outubro de 2014). 


\section{ANEXO 4}

\begin{tabular}{|c|c|}
\hline \multicolumn{2}{|c|}{$\begin{array}{l}\text { Competência dos órgãos do Ministério da Saúde para a formulação de iniciativas de política externa } \\
\text { em } 2010\end{array}$} \\
\hline $\begin{array}{l}\text { Art. 12. Assessoria de } \\
\text { Assuntos Internacionais de } \\
\text { Saúde }\end{array}$ & $\begin{array}{l}\text { I - assessorar o Ministro de Estado e demais autoridades do Ministério da Saúde, no país e no } \\
\text { exterior, em assuntos internacionais de interesse do Ministério da Saúde; } \\
\text { V - assessorar o Ministro de Estado da Saúde, nos assuntos administrativos relacionados a missões } \\
\text { no exterior, decorrentes de compromissos do Ministério da Saúde }\end{array}$ \\
\hline $\begin{array}{l}\text { Art.14. Serviços de Projeto } \\
\text { I, II e III }\end{array}$ & $\begin{array}{l}\text { I - acompanhar as discussões técnicas na elaboração de acordos, programas e projetos no âmbito da } \\
\text { cooperação internacional, de ações de assistência humanitária e de mecanismos de integração } \\
\text { regional e sub-regional; } \\
\text { II - examinar e encaminhar às áreas competentes do Ministério da Saúde as solicitações relativas à } \\
\text { cooperação internacional, às ações de assistência humanitária e aos mecanismos de integração } \\
\text { regional e sub-regional; e } \\
\text { III - acompanhar as discussões técnicas conduzidas pelo Ministério da Saúde no âmbito da } \\
\text { cooperação nas fronteiras }\end{array}$ \\
\hline $\begin{array}{l}\text { Art. 15. Divisão de Análise } \\
\text { Técnica }\end{array}$ & $\begin{array}{l}\text { I - promover, orientar e acompanhar, em articulação com o Ministério das Relações Exteriores, } \\
\text { negociações no Sistema das Nações Unidas e nos demais foros, incluindo os não exclusivos para a } \\
\text { saúde }\end{array}$ \\
\hline $\begin{array}{l}\text { Art. 16. Serviços de Análise } \\
\text { Técnica I, II e III }\end{array}$ & $\begin{array}{l}\text { II - participar de Comissões, Grupos de Trabalho e outros mecanismos internos ao Ministério da } \\
\text { Saúde ou intergovernamentais que tratem de temas internacionais conduzidos no âmbito da Divisão } \\
\text { de Análise Técnica; e } \\
\text { III - manter sistema de busca e identificação de temas novos e/ou emergentes de interesse para a } \\
\text { saúde em foros internacionais }\end{array}$ \\
\hline $\begin{array}{l}\text { Art. } \quad 40 . \quad \text { Secretaria- } \\
\text { Executiva }\end{array}$ & $\begin{array}{l}\text { VIII - assessorar a direção dos órgãos do Ministério na formulação de estratégias de colaboração } \\
\text { com organismos financeiros internacionais }\end{array}$ \\
\hline $\begin{array}{l}\text { Art. 53. Coordenação de } \\
\text { Biblioteca }\end{array}$ & $\begin{array}{l}\text { IV - assessorar a CGDI na proposição de ações e projetos a serem realizados em cooperação técnica } \\
\text { com organismos internacionais afins aos temas de informação e gestão do conhecimento }\end{array}$ \\
\hline $\begin{array}{l}\text { Art. } 71 . \text { Centro Cultural do } \\
\text { Ministério da Saúde }\end{array}$ & $\begin{array}{l}\text { II - assessorar a Coordenação-Geral de Documentação e Informação no fomento e intercâmbio de } \\
\text { parcerias nacionais e internacionais que permitam a realização de exposições e eventos } \\
\text { socioculturais }\end{array}$ \\
\hline
\end{tabular}

Fonte: Ministério da Saúde, 2010b. 
ANEXO 5

\begin{tabular}{|c|c|}
\hline \multicolumn{2}{|c|}{$\begin{array}{c}\text { Competência dos órgãos do Ministério da Saúde para a implementação de iniciativas de política } \\
\text { externa em } 2010\end{array}$} \\
\hline $\begin{array}{l}\text { Art. 15. Divisão de Análise } \\
\text { Técnica }\end{array}$ & $\begin{array}{l}\text { II - participar, resguardada sua competência, de mecanismos internos que possuam interface com } \\
\text { temas internacionais de saúde }\end{array}$ \\
\hline $\begin{array}{l}\text { Art. 16. Serviços de Análise } \\
\text { Técnica I, II e III }\end{array}$ & $\begin{array}{l}\text { I - acompanhar a internalização de compromissos internacionais multilaterais pelas áreas técnicas } \\
\text { do Ministério da Saúde, no âmbito de suas respectivas competências }\end{array}$ \\
\hline $\begin{array}{l}\text { Art. 525. Coordenação- } \\
\text { Geral de Assuntos } \\
\text { Regulatórios }\end{array}$ & $\begin{array}{l}\text { IV - avaliar, orientar, supervisionar e controlar as ações das políticas nacionais e internacionais nas } \\
\text { áreas de biossegurança, de biotecnologia, do patrimônio genético e de propriedade intelectual }\end{array}$ \\
\hline $\begin{array}{l}\text { Art. 556. Coordenação- } \\
\text { Geral de Doenças } \\
\text { Transmissíveis }\end{array}$ & $\begin{array}{l}\text { IX - coordenar e/ou executar as ações de prevenção e controle das doenças transmissíveis e agravos } \\
\text { de interesse à saúde pública em situações de emergências em saúde pública de importância nacional } \\
\text { ou internacional, de modo complementar ou suplementar, em articulação com as demais unidades } \\
\text { competentes }\end{array}$ \\
\hline $\begin{array}{l}\text { Art. 558. Coordenação- } \\
\text { Geral do Programa } \\
\text { Nacional de Imunizações }\end{array}$ & $\begin{array}{l}\text { VII - acompanhar os processos relativos à aquisição de imunobiológicos e outros insumos de seu } \\
\text { interesse, em âmbito nacional e internacional, bem como a distribuição, em articulação com as } \\
\text { demais unidades competentes }\end{array}$ \\
\hline $\begin{array}{l}\text { Art. 578. Instituto Evandro } \\
\text { Chagas }\end{array}$ & $\begin{array}{l}\text { X - prestar assessoria técnico-científica para o Sistema Único de Saúde e colaborar com instituições } \\
\text { nacionais e organismos internacionais em sua área de atuação; }\end{array}$ \\
\hline $\begin{array}{l}\text { Art. 579. Serviço de } \\
\text { Administração }\end{array}$ & III - gerenciar administrativamente os acordos com organismos internacionais \\
\hline
\end{tabular}

Fonte: Ministério da Saúde, 2010b. 
ANEXO 6

\begin{tabular}{|c|c|}
\hline \multicolumn{2}{|c|}{$\begin{array}{l}\text { Competência dos órgãos do Ministério da Saúde para a formulação e implementação de iniciativas de } \\
\text { política externa em } 2010\end{array}$} \\
\hline $\begin{array}{l}\text { Art. 12. Assessoria de } \\
\text { Assuntos Internacionais de } \\
\text { Saúde }\end{array}$ & $\begin{array}{l}\text { II - promover, articular, orientar e coordenar as ações internacionais de interesse do Ministério da } \\
\text { Saúde relacionadas a negociações com outros países, organismos internacionais, mecanismos de } \\
\text { integração regional e sub-regional e convenções internacionais; } \\
\text { III - promover, articular e coordenar as ações internacionais de interesse do Ministério da Saúde } \\
\text { relacionadas à cooperação técnica, educacional, científica e tecnológica, nas áreas de competência } \\
\text { do Ministério da Saúde; } \\
\text { IV - atuar como interlocutor do Ministério da Saúde em todas as atividades referentes às relações } \\
\text { internacionais, tanto no atendimento a demandas como na apresentação de propostas de seu } \\
\text { interesse }\end{array}$ \\
\hline Art. 13. Divisão de Projetos & $\begin{array}{l}\text { I - promover, articular, acompanhar e coordenar a elaboração de acordos, programas e projetos no } \\
\text { âmbito da cooperação técnica, educacional, científica e tecnológica internacional do Ministério da } \\
\text { Saúde; } \\
\text { II - promover, articular, acompanhar e coordenar iniciativas de cooperação internacional do } \\
\text { Ministério da Saúde; } \\
\text { III - promover, articular, acompanhar e coordenar as atividades internacionais conduzidas pelo } \\
\text { Ministério da Saúde nas regiões fronteiriças, inclusive a negociação de acordos; e } \\
\text { IV - promover, articular, orientar e coordenar os mecanismos de integração regional e sub-regional } \\
\text { no âmbito da saúde }\end{array}$ \\
\hline $\begin{array}{l}\text { Art. } \quad 40 . \quad \text { Secretaria- } \\
\text { Executiva }\end{array}$ & $\begin{array}{l}\text { XI - elaborar e acompanhar a execução dos termos de convênios e outros instrumentos de interesse } \\
\text { da Coordenação-Geral de Documentação e Informação (CGDI) relativos a organismos } \\
\text { internacionais }\end{array}$ \\
\hline $\begin{array}{l}\text { Art. 51. Coordenação- } \\
\text { Geral de Documentação e } \\
\text { Informação }\end{array}$ & $\begin{array}{l}\text { VI - promover e coordenar ações de intercâmbio e de cooperação técnica nacional e internacional } \\
\text { junto a instituições de interesse da saúde pública em prol da preservação e disseminação das } \\
\text { informações em saúde }\end{array}$ \\
\hline $\begin{array}{l}\text { Art. 53. Coordenação de } \\
\text { Biblioteca }\end{array}$ & $\begin{array}{l}\text { VI - propor, recomendar e promover a integração do conhecimento institucional do Ministério da } \\
\text { Saúde com a informação técnico-científica nacional e internacional }\end{array}$ \\
\hline $\begin{array}{l}\text { Art. 59. Coordenação de } \\
\text { Arquivo e Gestão de } \\
\text { Documentos }\end{array}$ & $\begin{array}{l}\text { VIII - promover intercâmbio e ações de cooperação técnica com instituições arquivísticas e } \\
\text { entidades do setor de saúde em nível nacional e internacional }\end{array}$ \\
\hline $\begin{array}{l}\text { Art. 71. Centro Cultural do } \\
\text { Ministério da Saúde }\end{array}$ & $\begin{array}{l}\text { III - promover, desenvolver, acompanhar e coordenar parcerias ou cooperação técnica nacional e } \\
\text { internacional com instituições detentoras de acervos de interesse para a história e o patrimônio } \\
\text { cultural da saúde, contribuindo para sua preservação, organização e acesso }\end{array}$ \\
\hline $\begin{array}{l}\text { Art. 72. Divisão de } \\
\text { Produção Cultural }\end{array}$ & $\begin{array}{l}\text { I - promover e acompanhar as ações relativas à Rede Brasileira de História e Patrimônio Cultural } \\
\text { da Saúde e apoiar ações de cooperação técnica nacional e internacional }\end{array}$ \\
\hline $\begin{array}{l}\text { Art. 262. Coordenação- } \\
\text { Geral de Sangue e } \\
\text { Hemoderivados }\end{array}$ & $\begin{array}{l}\text { V - promover programas de cooperação técnica com organismos e instituições nacionais e } \\
\text { internacionais, visando ao desenvolvimento da área }\end{array}$ \\
\hline $\begin{array}{l}\text { Art. 502. Secretaria de } \\
\text { Gestão do Trabalho e da } \\
\text { Educação na Saúde }\end{array}$ & $\begin{array}{l}\text { IX - fomentar a cooperação internacional, inclusive mediante a instituição e a coordenação de } \\
\text { fóruns de discussão, visando à solução dos problemas relacionados à formação, ao desenvolvimento } \\
\text { profissional, à gestão e à regulação do trabalho em saúde, especialmente as questões que envolvam } \\
\text { os países vizinhos do continente americano, os países de língua portuguesa e os países do hemisfério } \\
\text { sul }\end{array}$ \\
\hline $\begin{array}{l}\text { Art. 521. Coordenação- } \\
\text { Geral de Gestão do } \\
\text { Conhecimento em Ciência } \\
\text { e Tecnologia }\end{array}$ & $\begin{array}{l}\text { VII - promover articulação institucional e parcerias nacionais e internacionais para o } \\
\text { desenvolvimento de redes colaborativas de divulgação do conhecimento científico e tecnológico }\end{array}$ \\
\hline $\begin{array}{l}\text { Art. 522. Coordenação- } \\
\text { Geral de Fomento } e \\
\text { Avaliação de Tecnologias } \\
\text { em Saúde }\end{array}$ & $\begin{array}{l}\text { XIV - articular parcerias com instituições internacionais de Ciência e Tecnologia e ATS visando à } \\
\text { cooperação técnica científica no âmbito da Política Nacional de Ciência, Tecnologia e Inovação } \\
\text { em Saúde }\end{array}$ \\
\hline $\begin{array}{l}\text { Art. 548. Coordenação de } \\
\text { Desenvolvimento }\end{array}$ & $\begin{array}{l}\text { IV - fomentar, promover e participar de eventos nacionais e internacionais sobre auditoria, gestão } \\
\text { do SUS, saúde pública e epidemiologia, atualizando-se e divulgando ações do DENASUS/SGEP }\end{array}$ \\
\hline
\end{tabular}




\begin{tabular}{|c|c|}
\hline $\begin{array}{l}\text { Art. 551. Secretaria de } \\
\text { Vigilância em Saúde }\end{array}$ & $\begin{array}{l}\text { IX - promover o intercâmbio técnico-científico, com organismos governamentais e não } \\
\text { governamentais, de âmbito nacional e internacional, na área de Vigilância em Saúde }\end{array}$ \\
\hline $\begin{array}{l}\text { Art. 571. Departamento de } \\
\text { Vigilância, Prevenção e } \\
\text { Controle das Doenças } \\
\text { Sexualmente } \\
\text { Transmissíveis, Síndrome } \\
\text { da Imunodeficiência } \\
\text { Adquirida e Hepatites } \\
\text { Virais }\end{array}$ & IV - prestar assessoria técnica e estabelecer cooperações nacionais e internacionais \\
\hline $\begin{array}{l}\text { Art. 572. Coordenação- } \\
\text { Geral deróes } \\
\text { Estratégicas em DST/AIDS }\end{array}$ & $\begin{array}{l}\text { planejar e coordenar a implementação das políticas, diretrizes e projetos estratégicos, no que se } \\
\text { refere: } \\
\text { IV - à cooperação técnica com organismos internacionais e governos estrangeiros; }\end{array}$ \\
\hline $\begin{array}{l}\text { Art. 576. Coordenação- } \\
\text { Geral de Vigilância em } \\
\text { Saúde Ambiental }\end{array}$ & XIII - promover a cooperação técnica internacional na área de vigilância em saúde ambiental; \\
\hline
\end{tabular}

Fonte: Ministério da Saúde, 2010b. 